
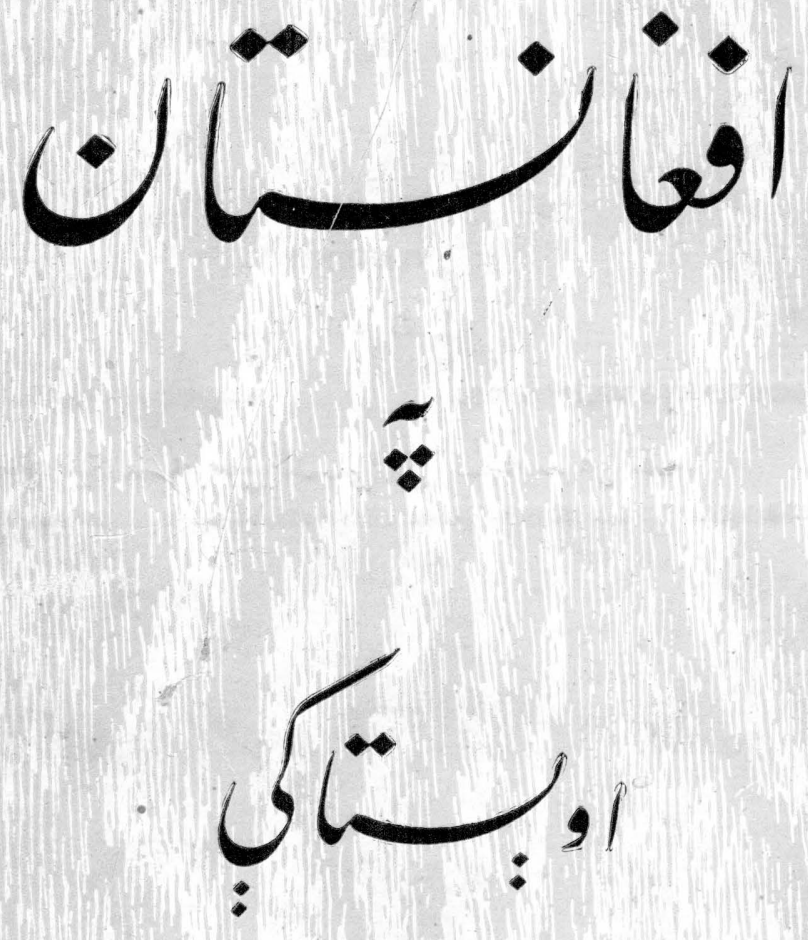

$$
\therefore
$$

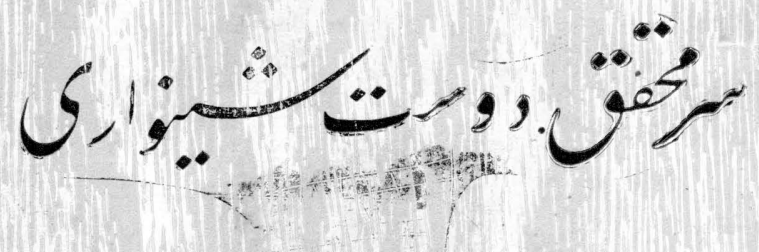

irya 


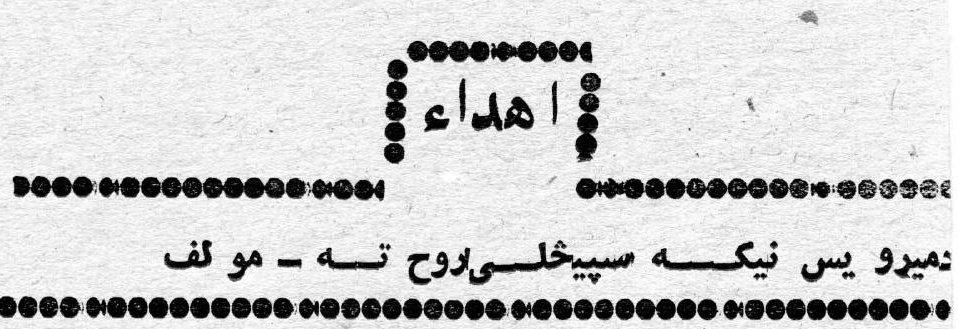




$$
=
$$


عنوا نيو زن

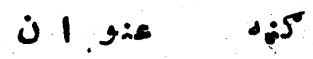

(i)

• 1

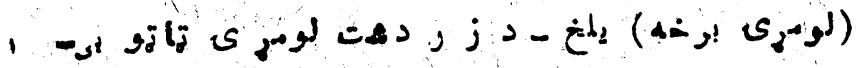

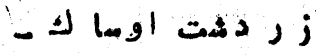

10

- د ز

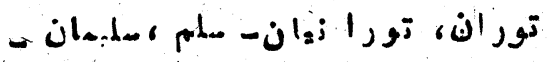

$r r$

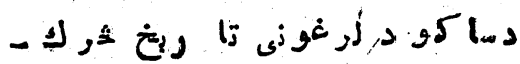

7.

$r y$

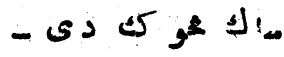

$r N$

ما

rr

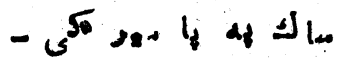

$n$

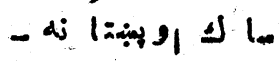

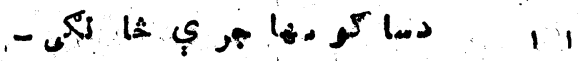

m. 7

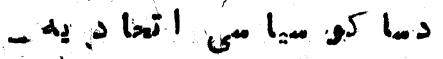

1.8

-

01

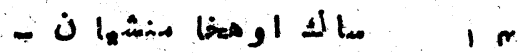

- $v$

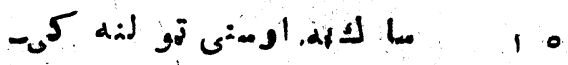

- 4

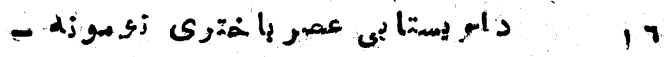

- $A$

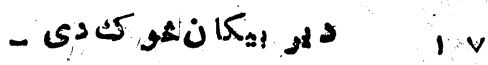

7.

- Is 1 i

91

-

19

$7 r$

-

$r$.

$7 r$

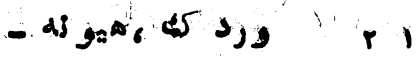

7

هنبه

$r$ 
ميخ

عنوان

$4+5$

70

7 o

$-j i s \quad r$

77

iv

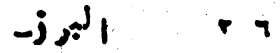

$v$

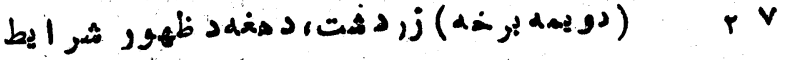

ا

$\mathbf{r}$

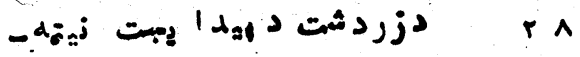

$\mathbf{v}$

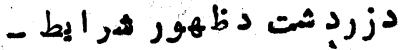

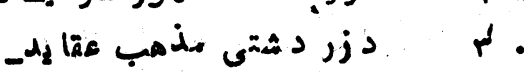

$\wedge r$

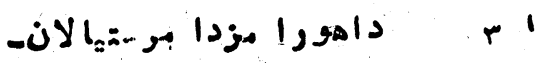

1. - -

ฯ 1

- si l i 1 i

I. r

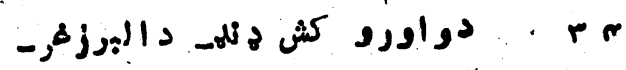

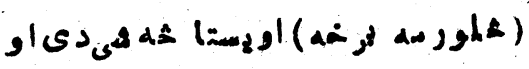

$1 \cdot A$

org aka abs

117

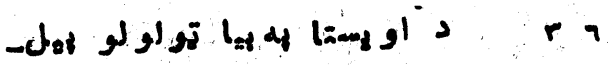

ir.

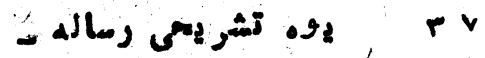

$\operatorname{lrt}$

A

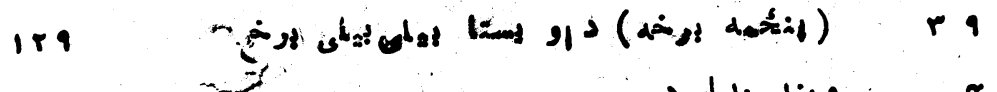

$1 \mathrm{rr}$

$\Rightarrow 1 d_{1} \operatorname{didg} \cdot r$

i $>$

$-\operatorname{limg}$

179

- dj sining

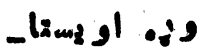

limp

-

$r r$

-dis is If 


\section{خو خبرى}

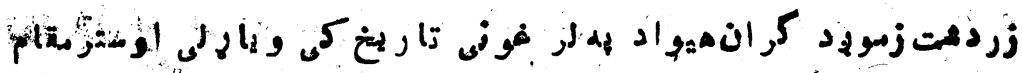

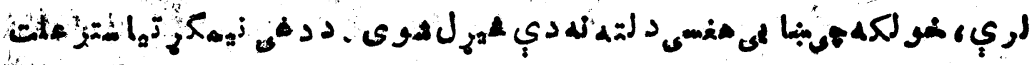

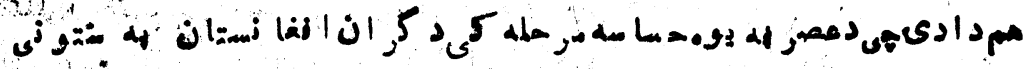

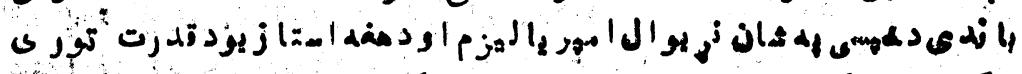

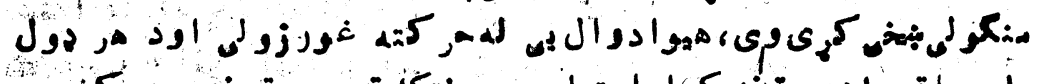

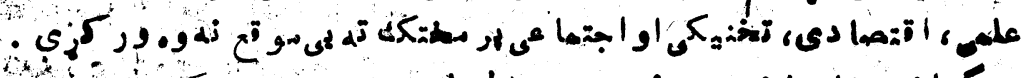

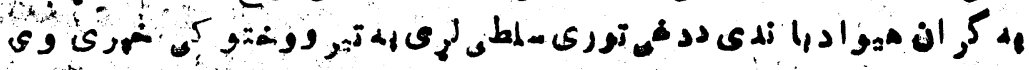

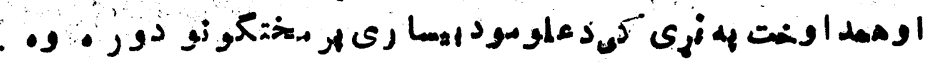
له

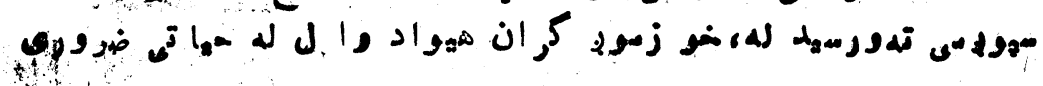

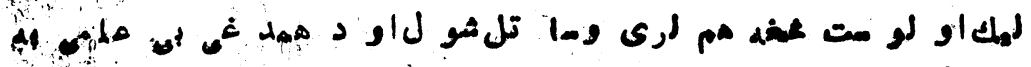

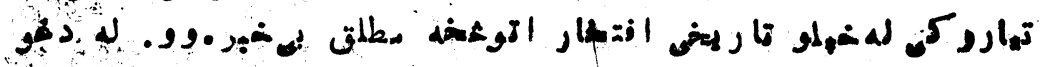

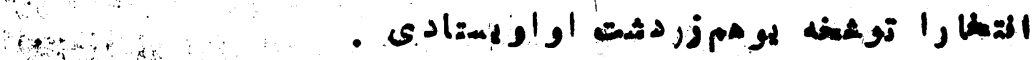

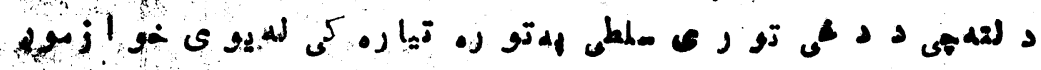

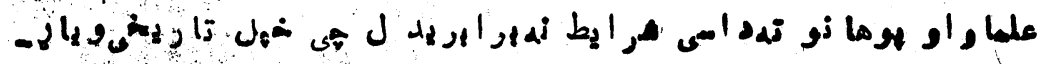

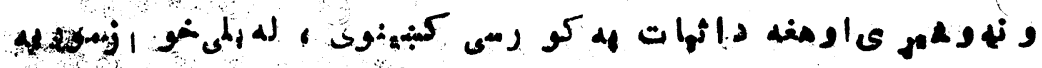

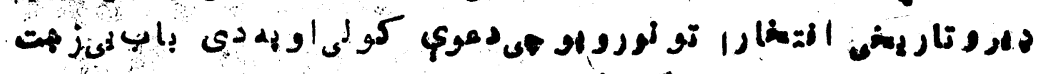

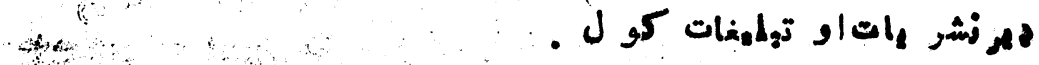

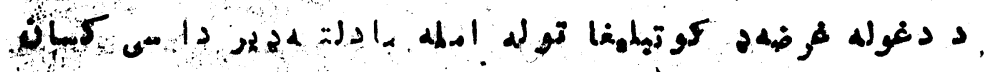

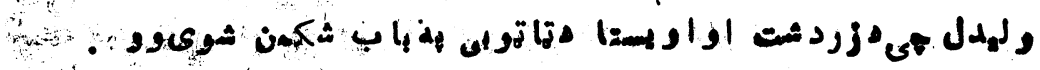

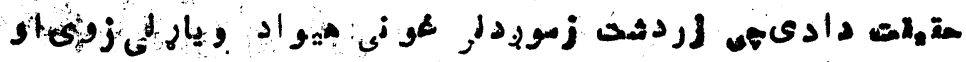

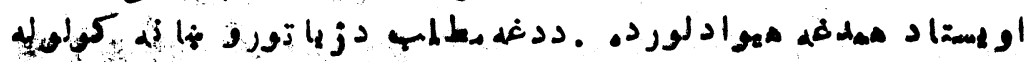

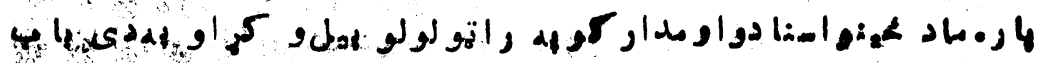

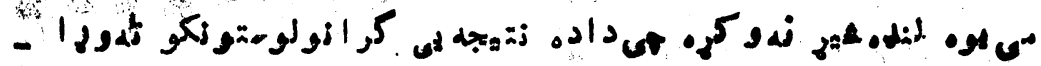
- bos cas 


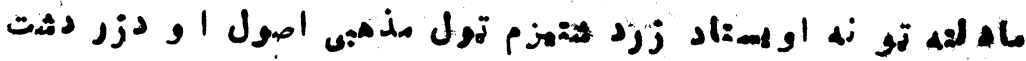

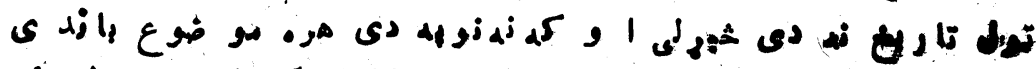

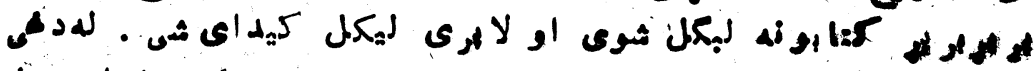

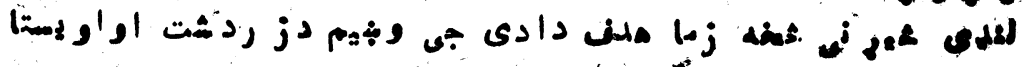

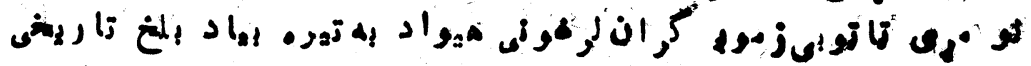

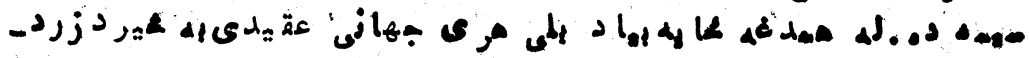

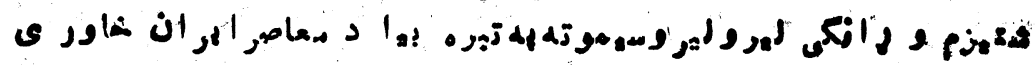

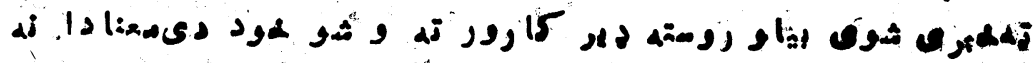

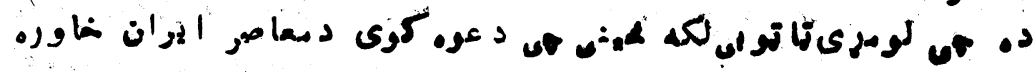
. 02

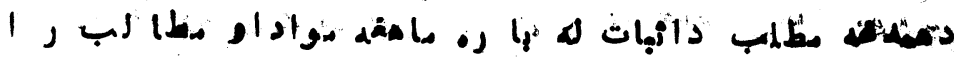

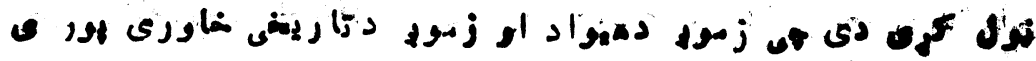

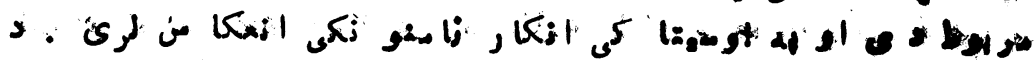

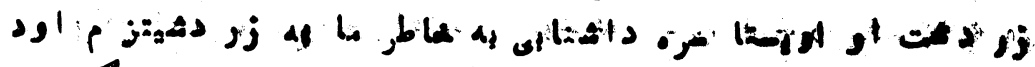

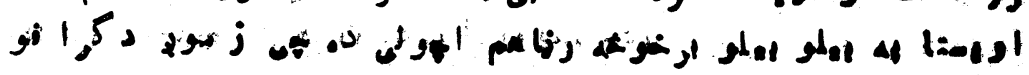

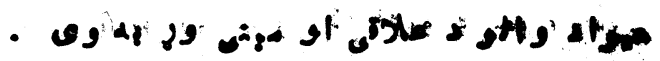

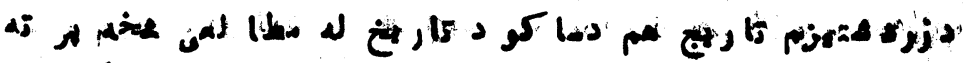

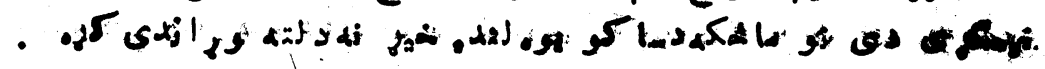

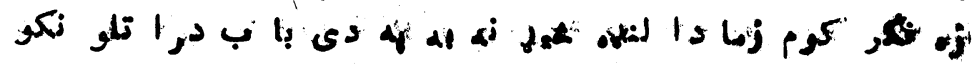

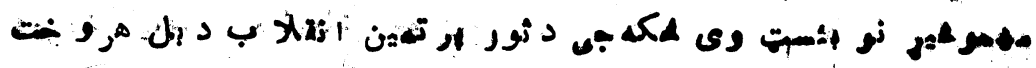

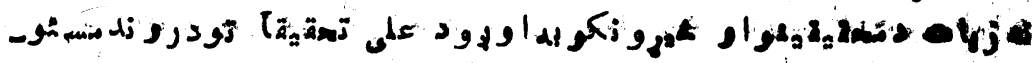

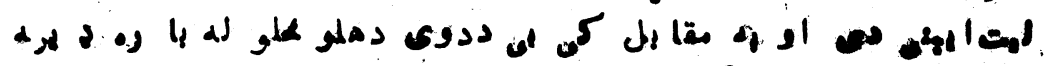

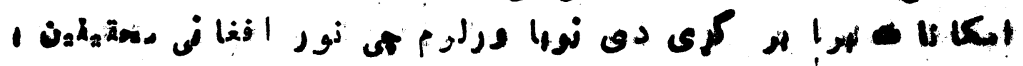

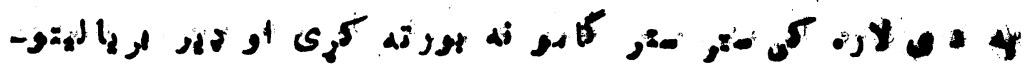

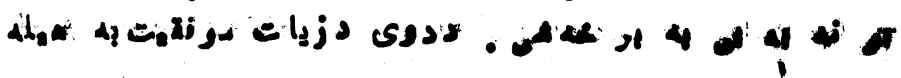

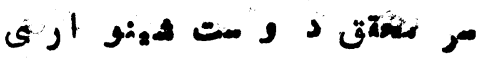

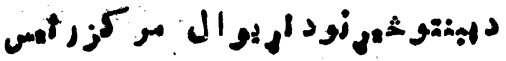




\section{دمؤلف نور كتابو نه}

الف : الفا

(هeganan

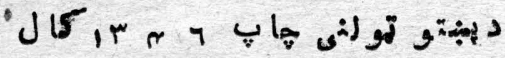
r

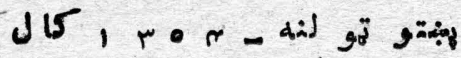

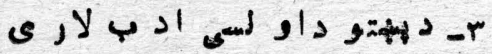

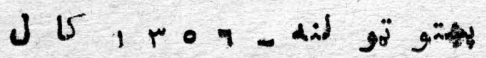
de

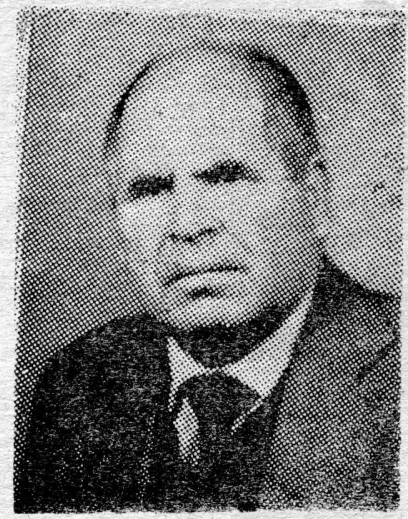
د

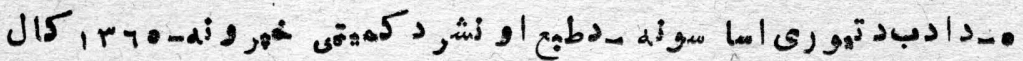

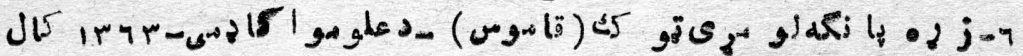

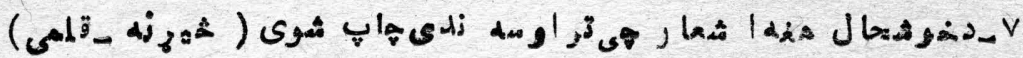

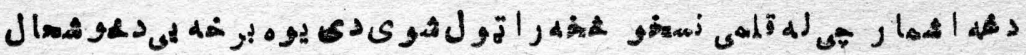
د د د

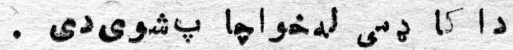

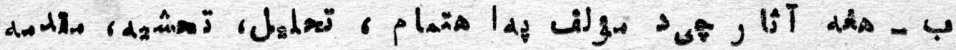

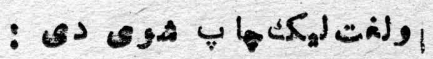
ل12,

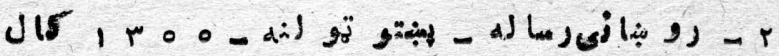

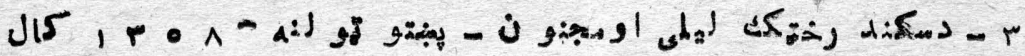

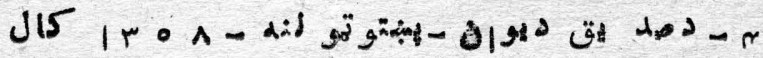

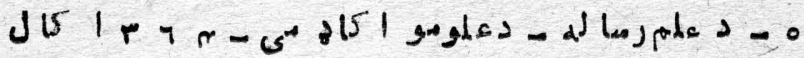

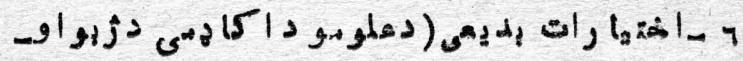

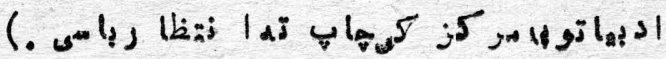


Afghanistan in Avesta by

\section{Prof. Dost ShinwaraY Kabul, 1990}

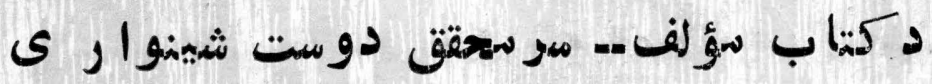

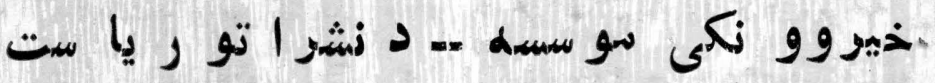

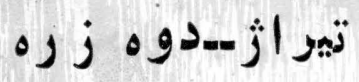

مهتمم - لطف الرحمن خاموش

$\cos ^{20+4} \sin ^{-3}$ 


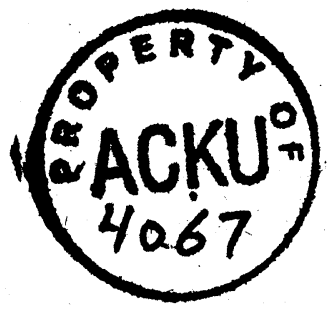

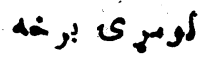

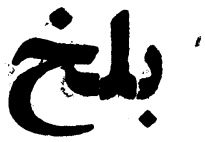

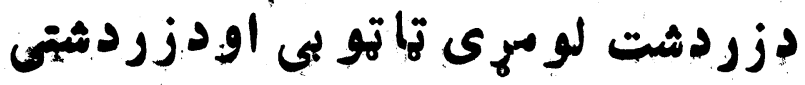

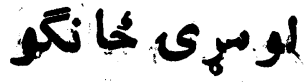

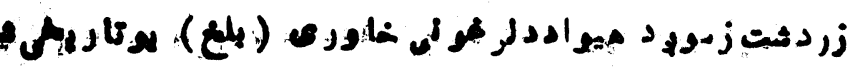

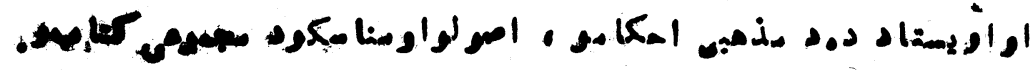

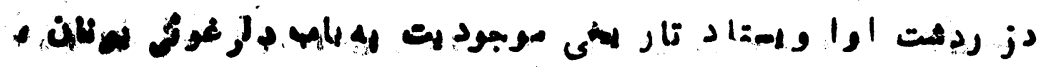

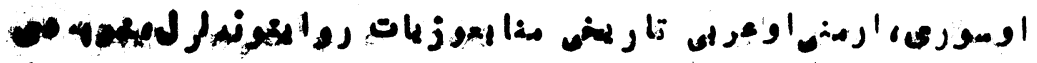

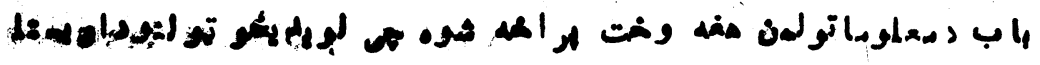

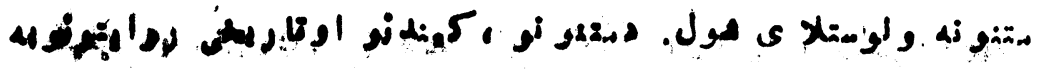

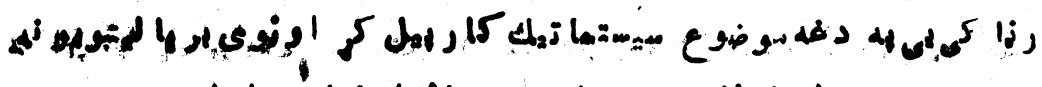

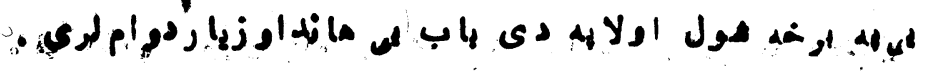

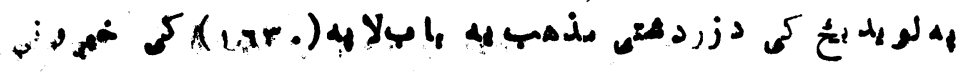

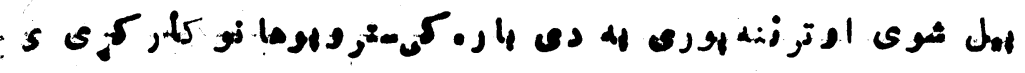

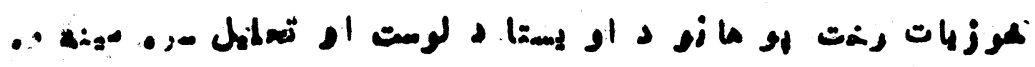

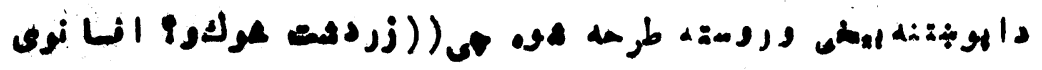




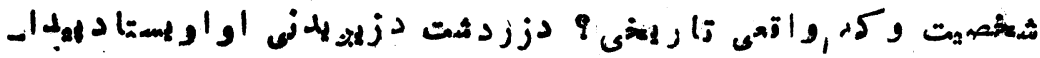

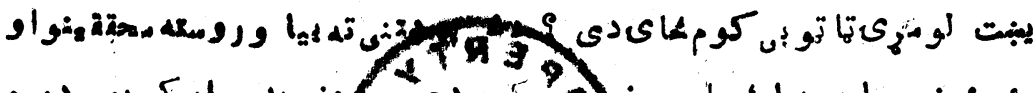

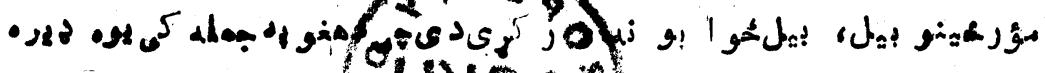

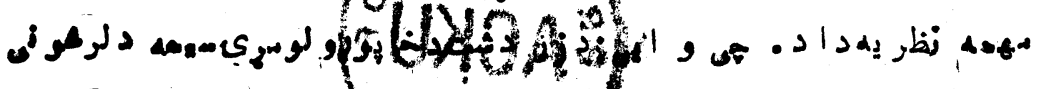

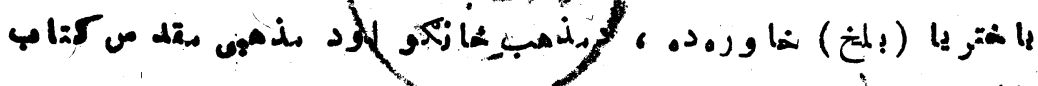

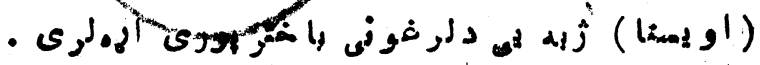

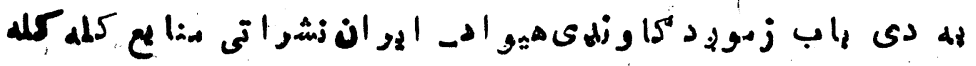

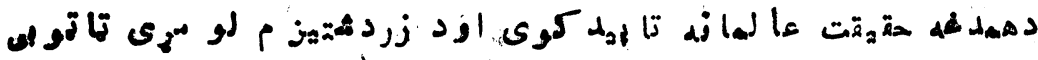

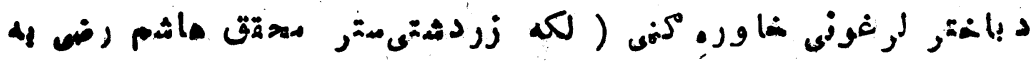

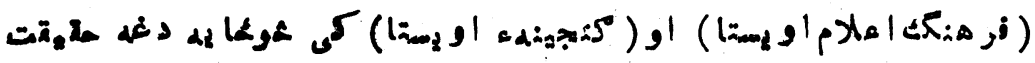

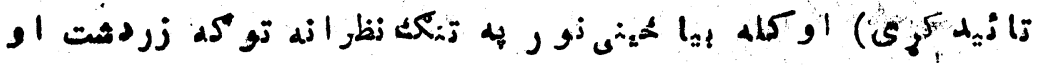

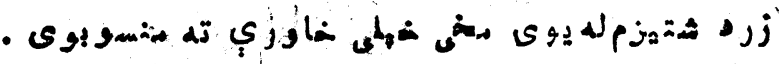

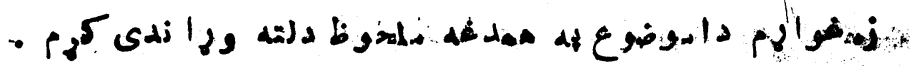

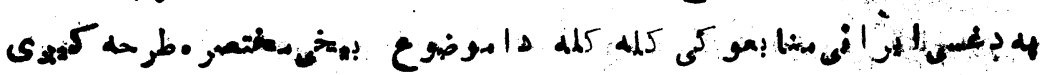

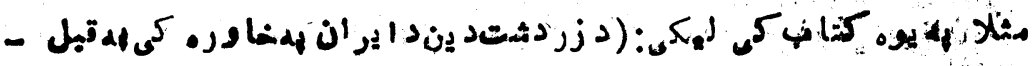

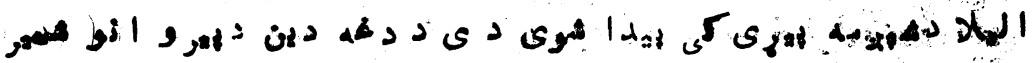

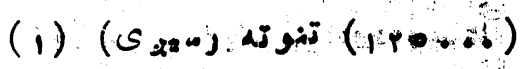

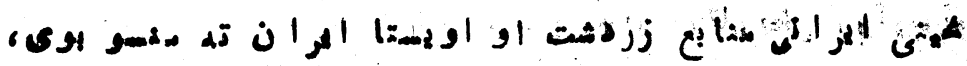

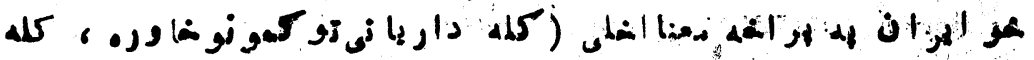

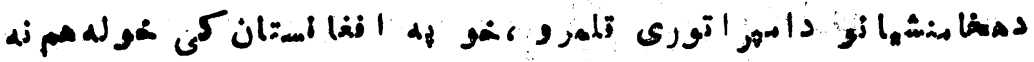

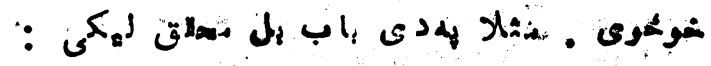

ا 
-P

افغال نستا لذكى ئما و إس:ا

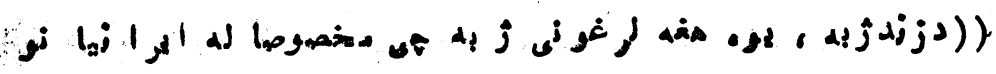

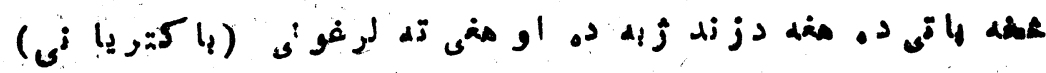

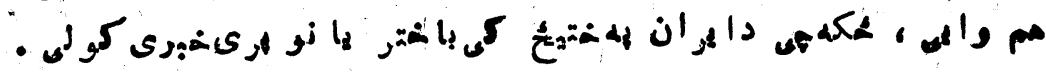

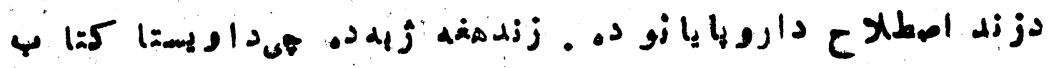

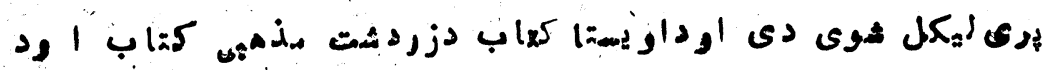

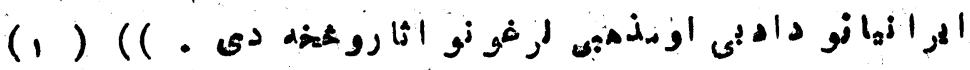

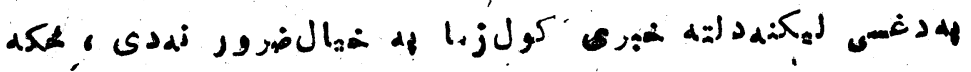

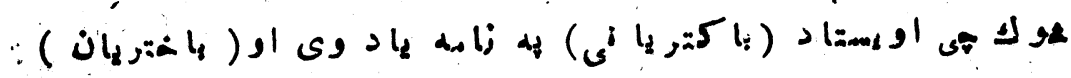

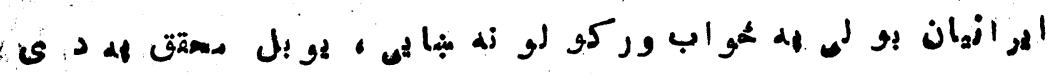

$$
\text { : }
$$

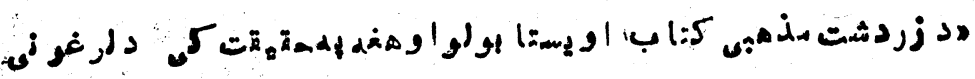

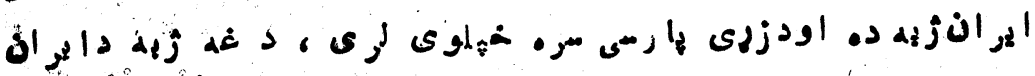

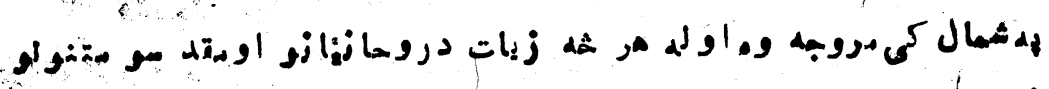

$$
\text { (r) . . }
$$

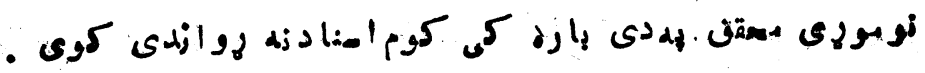

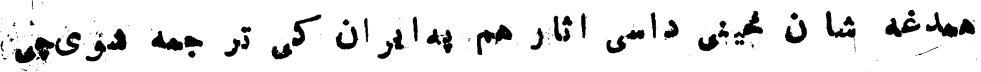

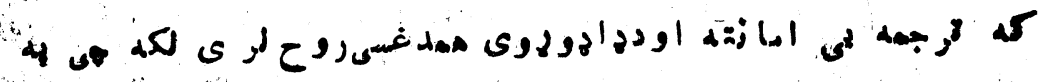

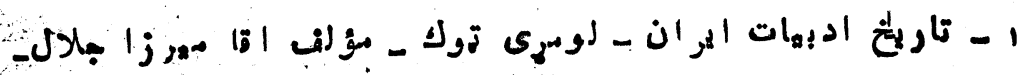

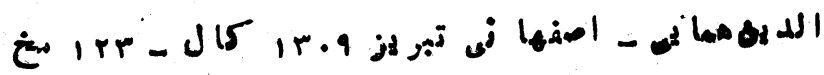

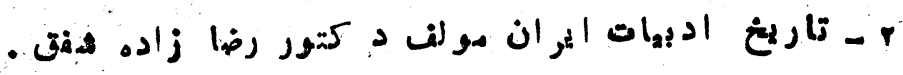
jis irrer 
t.

so

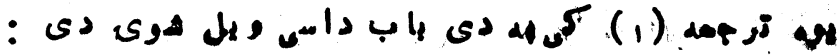

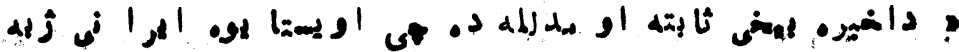

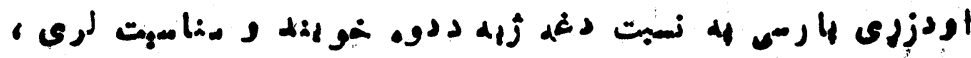

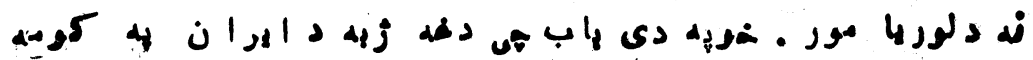

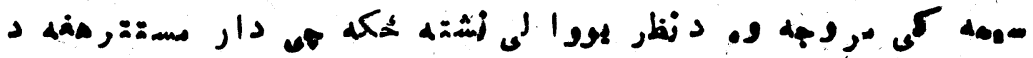

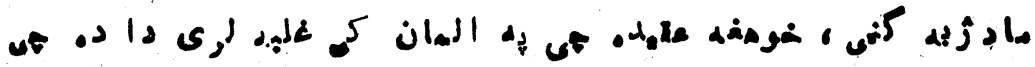

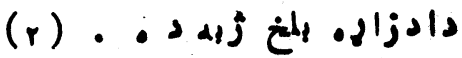

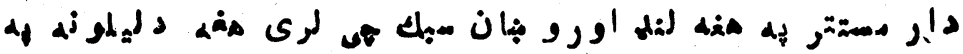

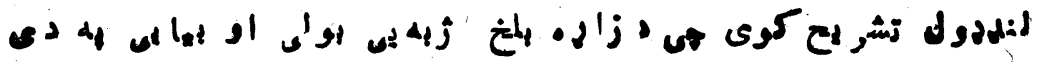
- vojujos

- .

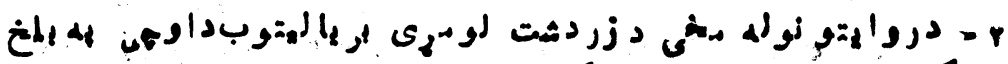
- ما

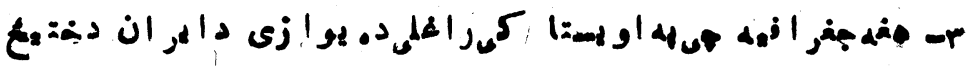

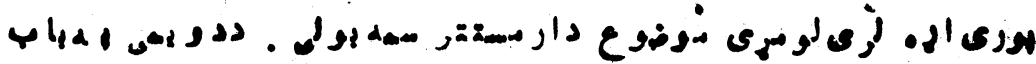

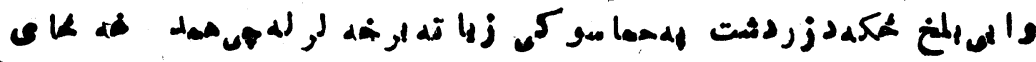

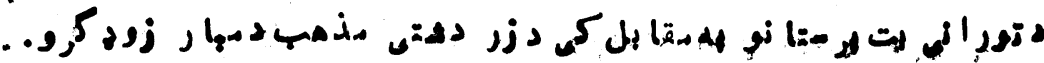

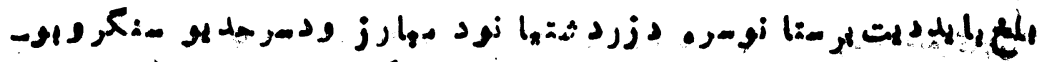

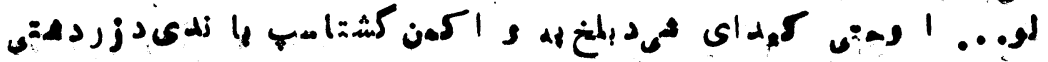

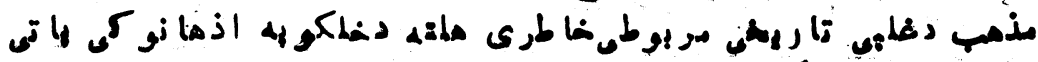

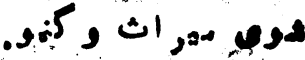

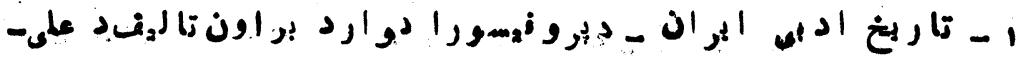

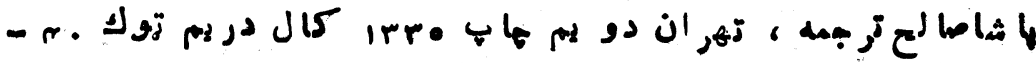

- dijers

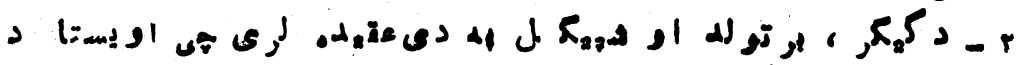

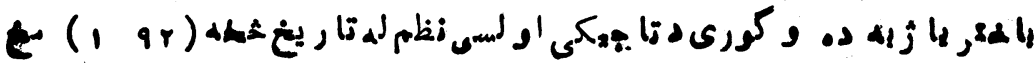


$\infty$

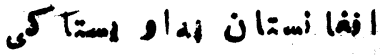

إ

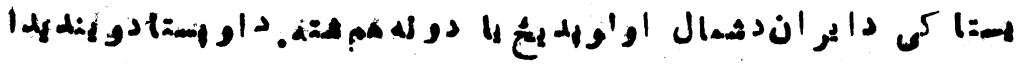

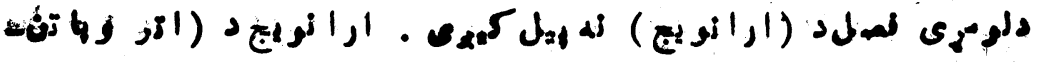

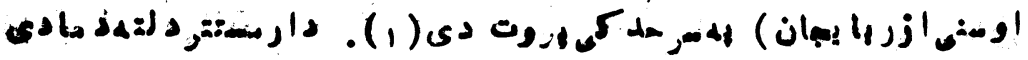

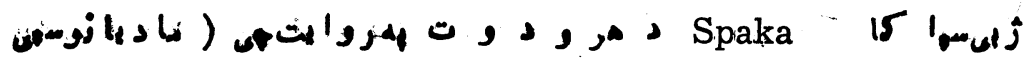

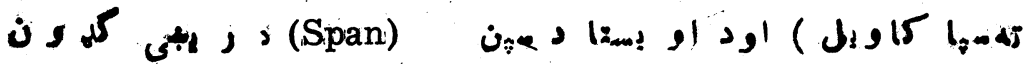

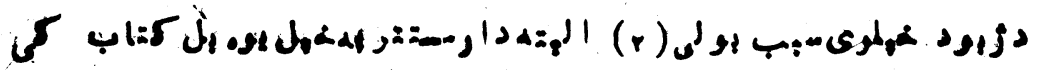

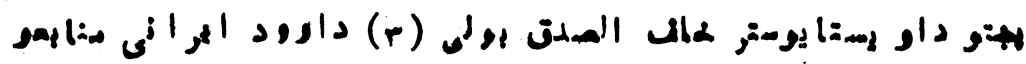

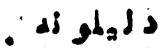

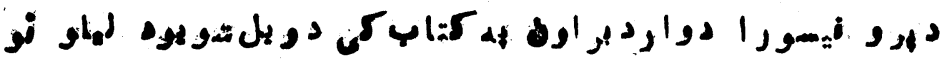

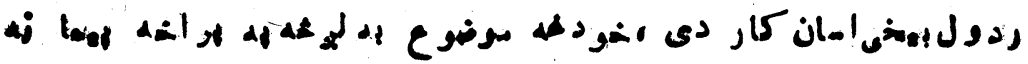

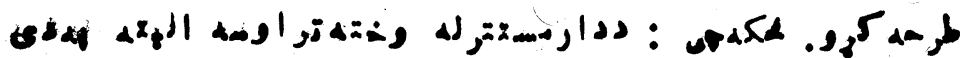

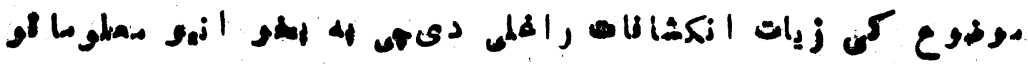

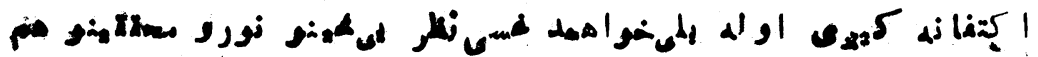

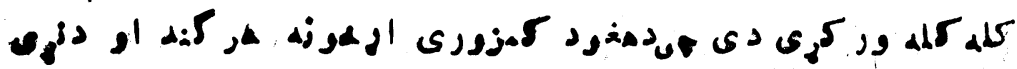

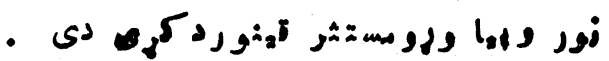

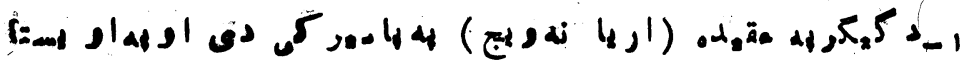

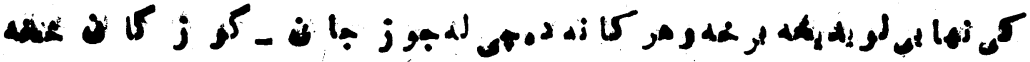

$\therefore 0$

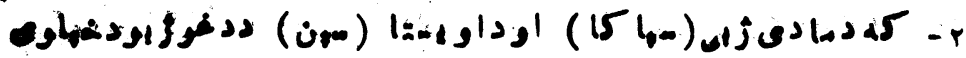

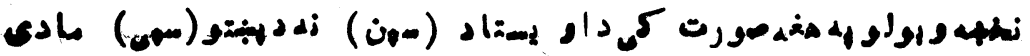

.

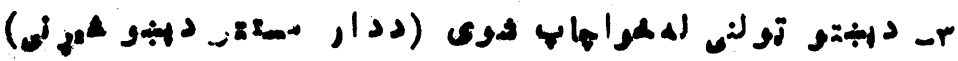

תלקנטים. 


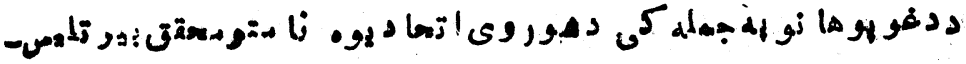

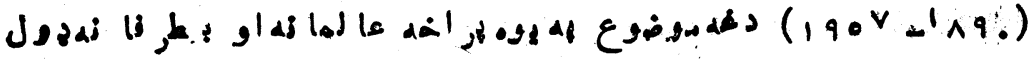

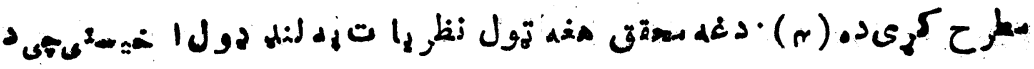

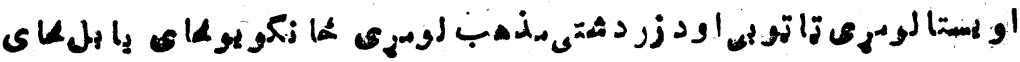

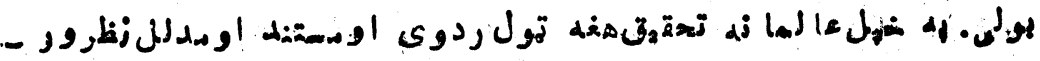

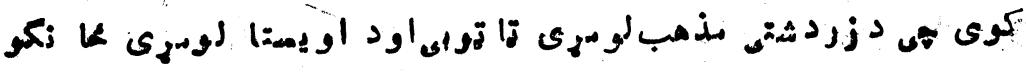

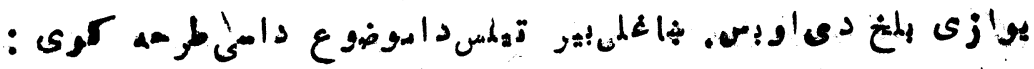

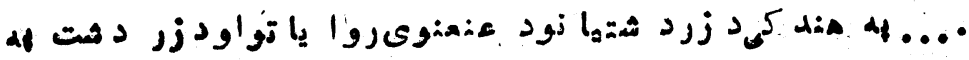

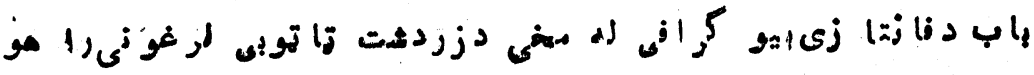

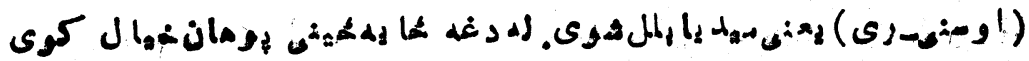

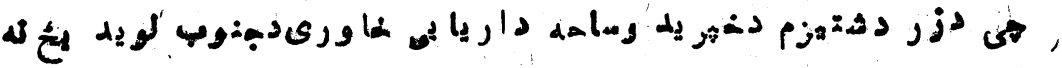

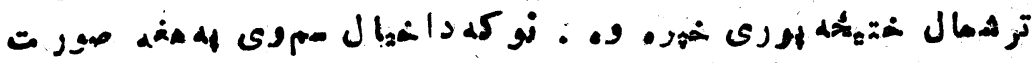

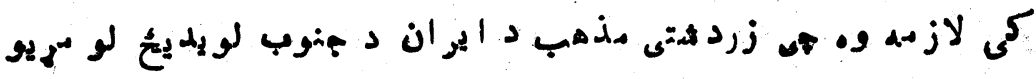

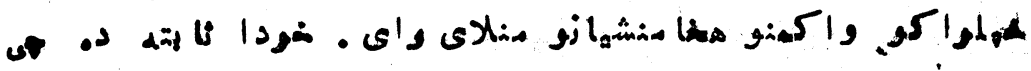

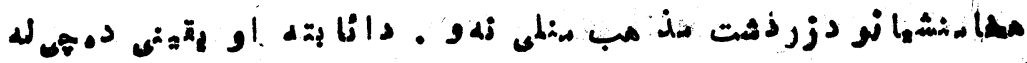

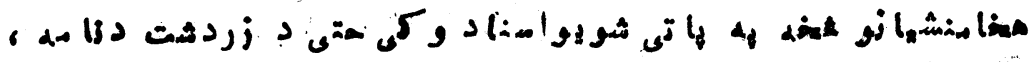

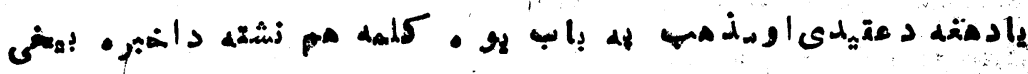

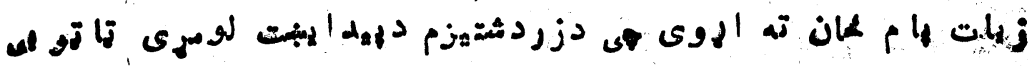

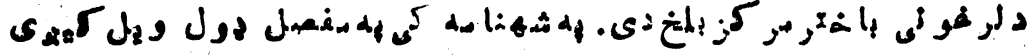

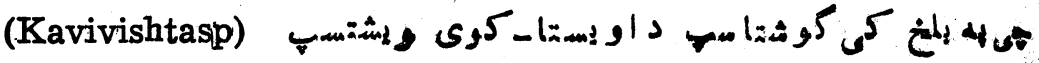

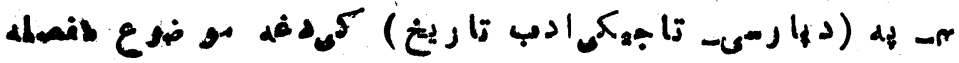

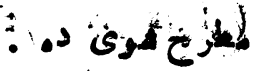


$-v-$

Singla

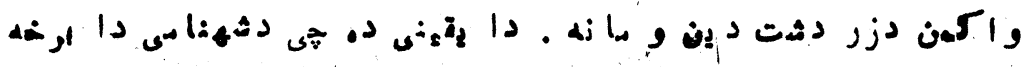

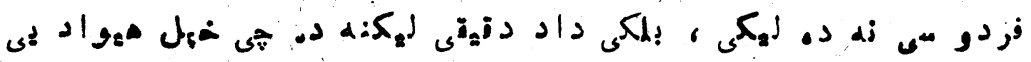

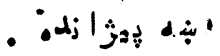

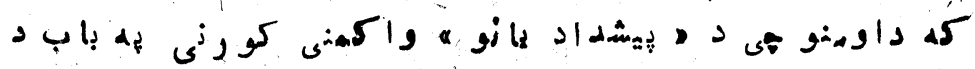

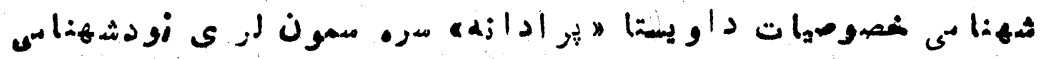

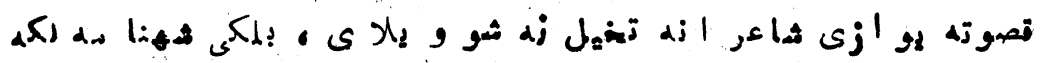

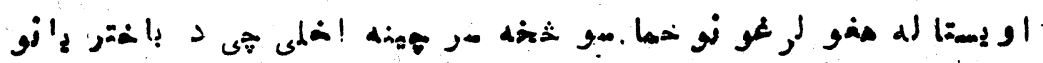

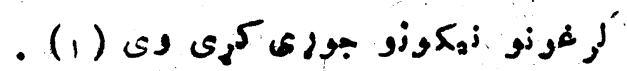

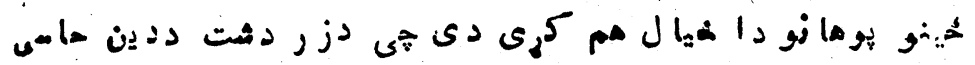

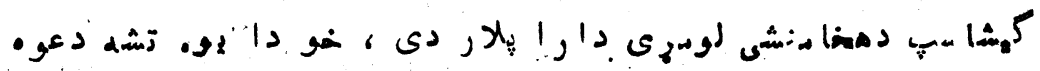

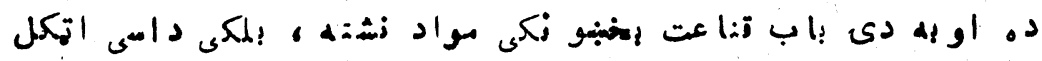

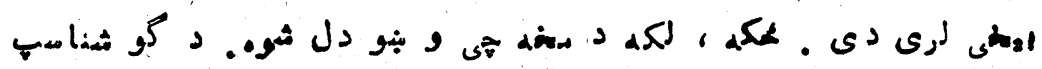

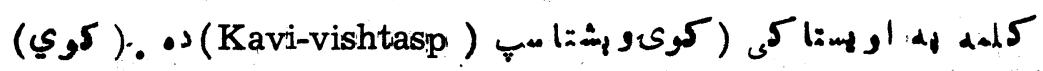

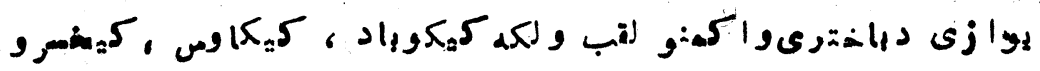

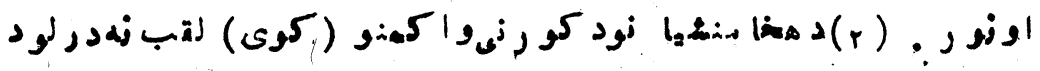

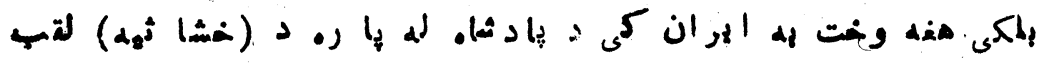

- Odalogel

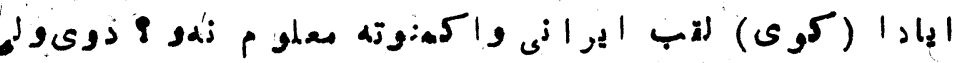

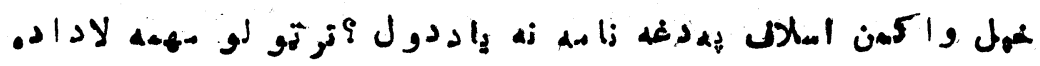

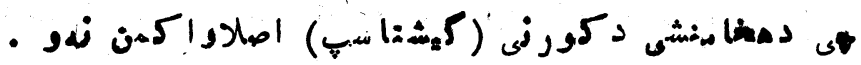

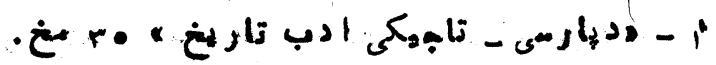

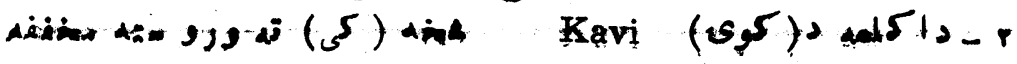

$\therefore$ ग د 
!

$-\wedge-$

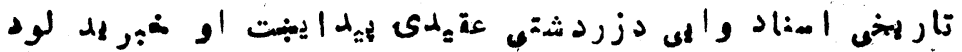

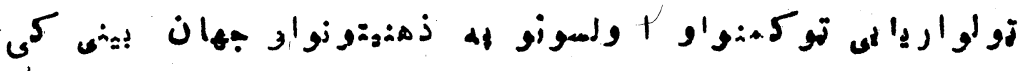

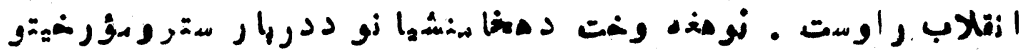

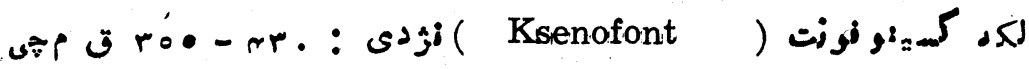

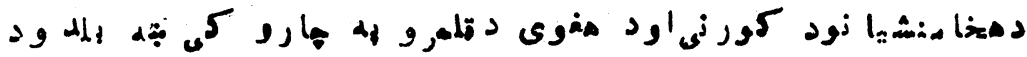

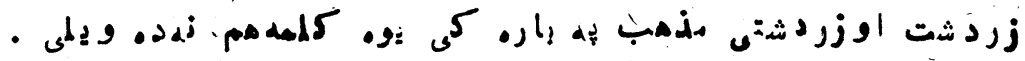
دى

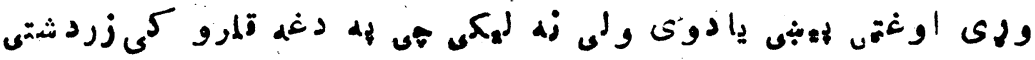

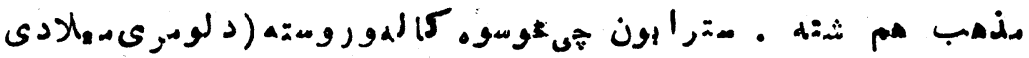

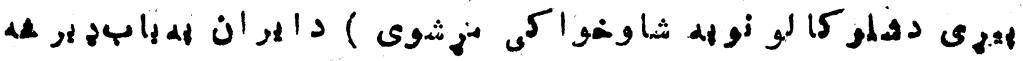

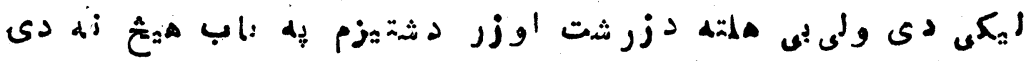

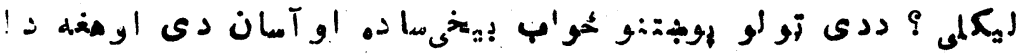

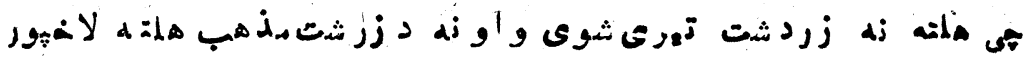
دوى و

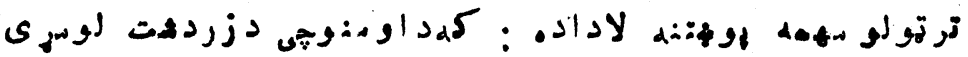

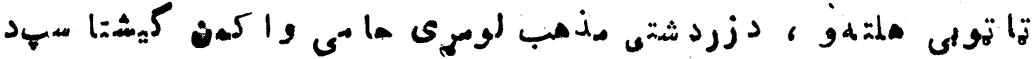

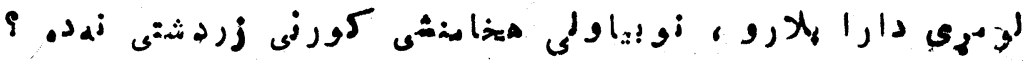

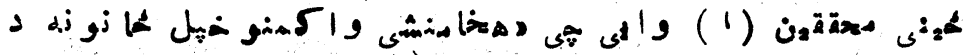

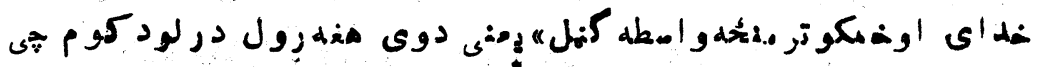

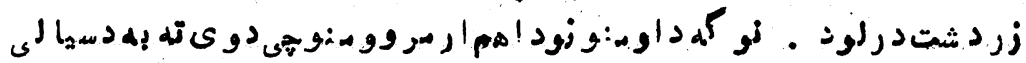

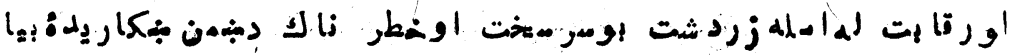
(1970-1 1^.9 V.V. Struve' ) 
$-9-$

كا

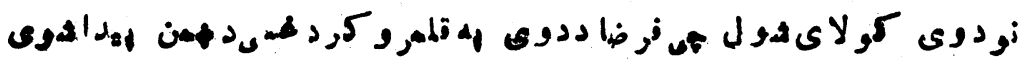

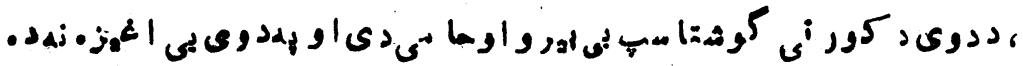

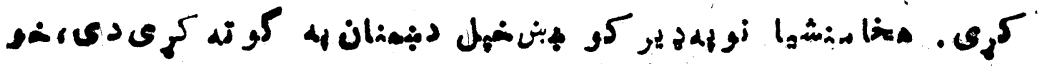

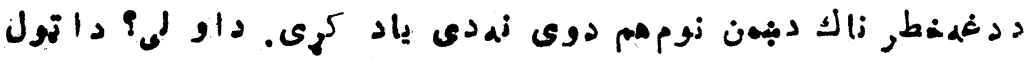

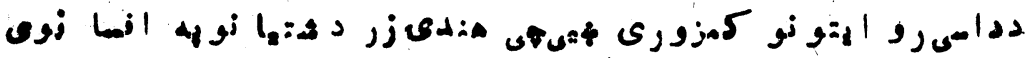

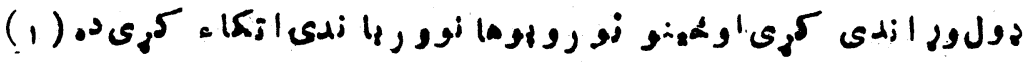

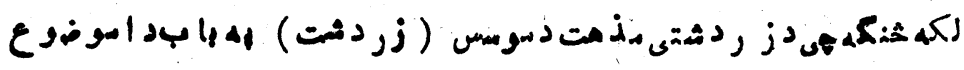

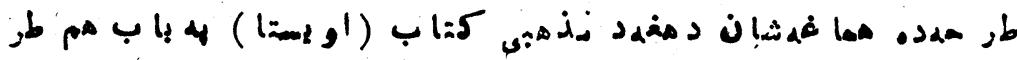

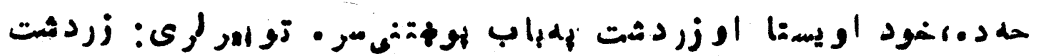

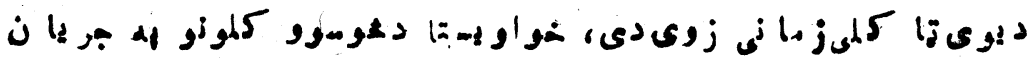

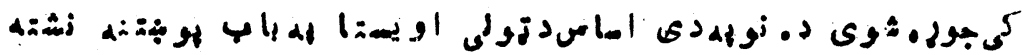

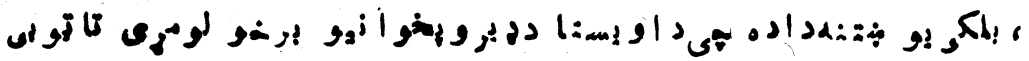

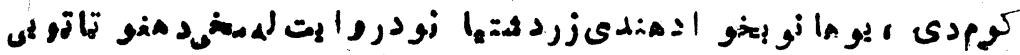

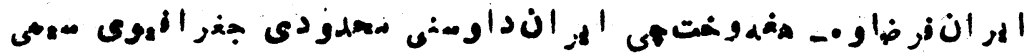

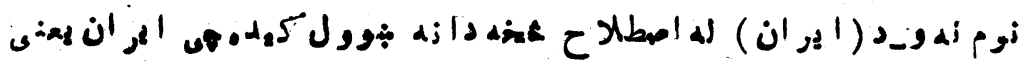

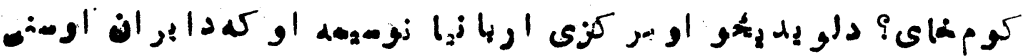

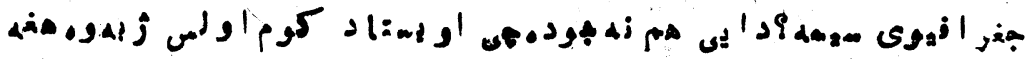

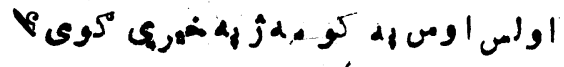

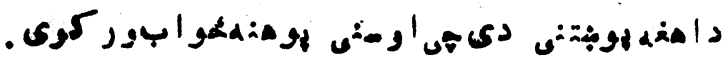

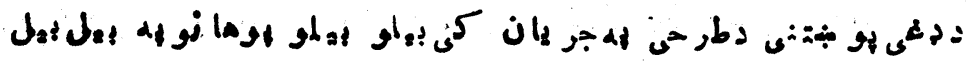

- 


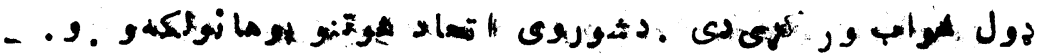

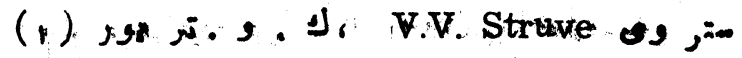

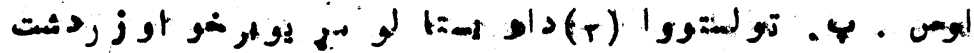

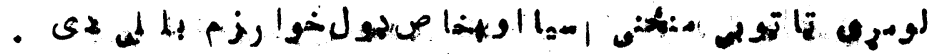

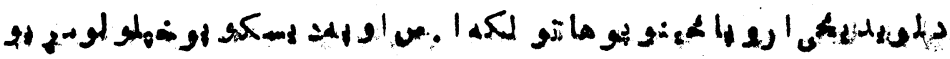
أt

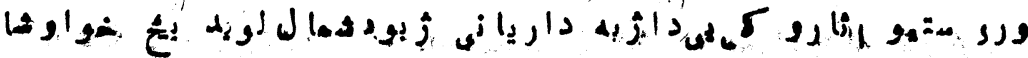

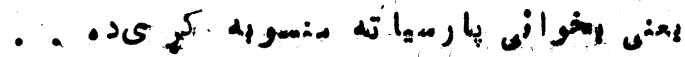

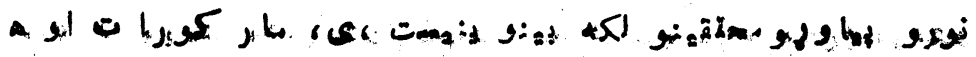

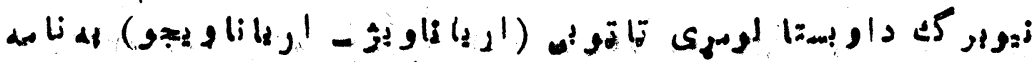

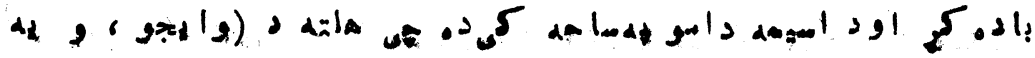

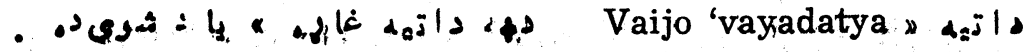

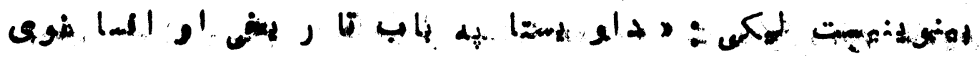

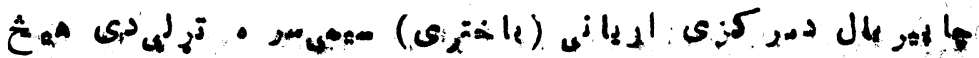

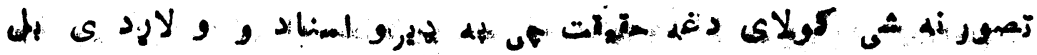
a.. $v w^{5}$ ils

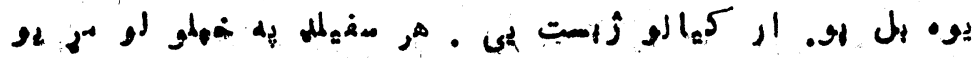

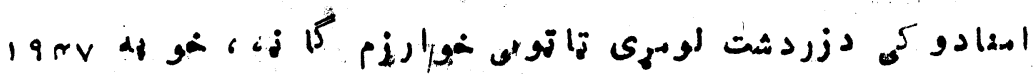

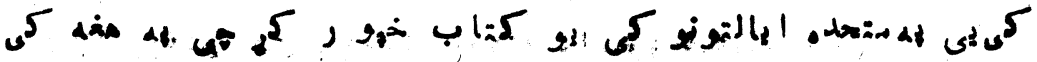

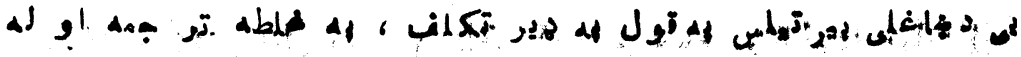




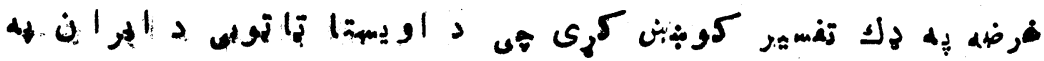

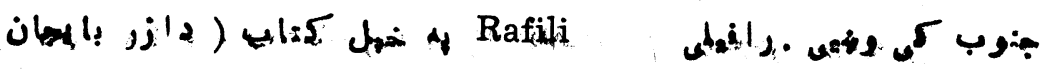

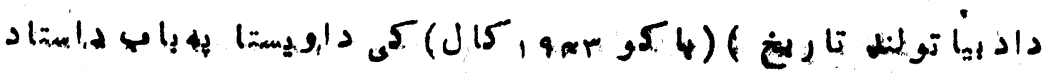

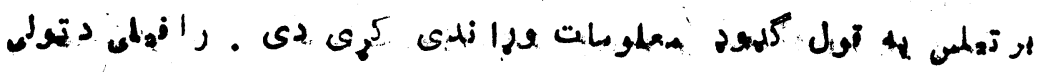

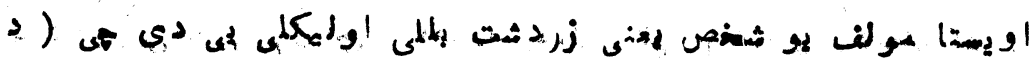

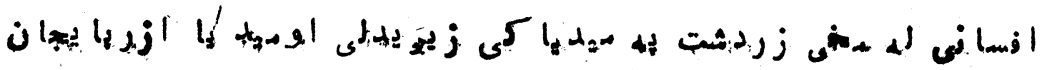

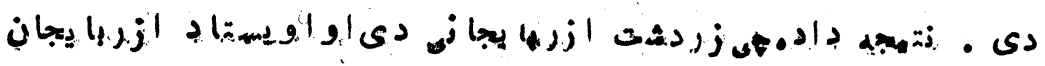

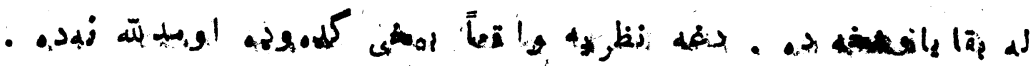

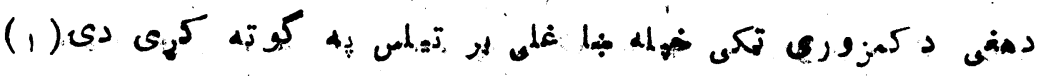
هـا مصر لوردن.

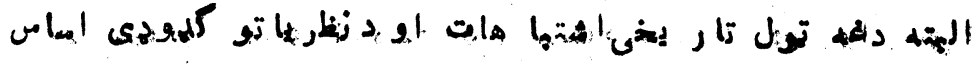

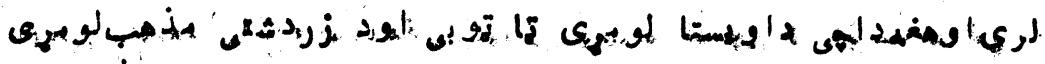

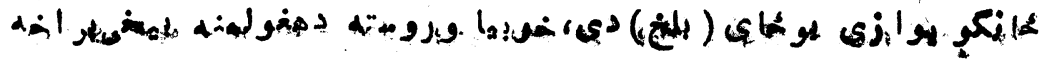

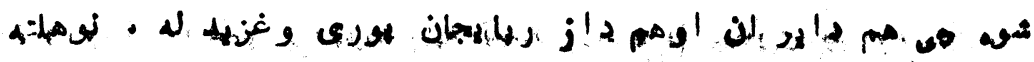
هis

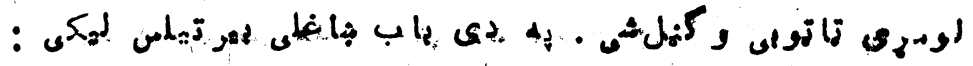

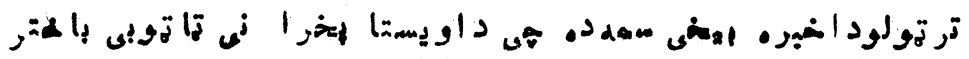

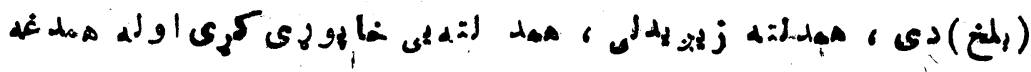

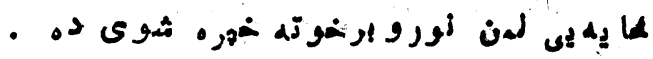

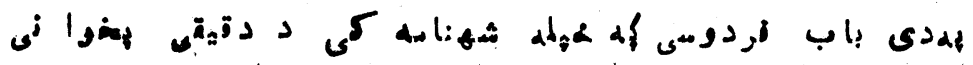

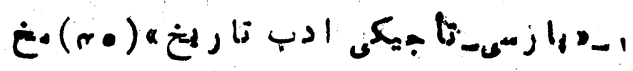


إلمغ

$-18-$

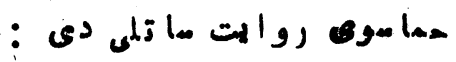

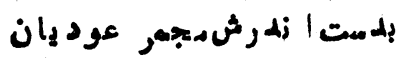

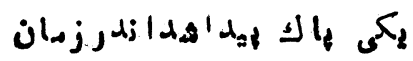

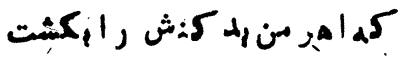

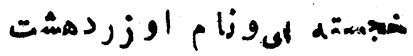

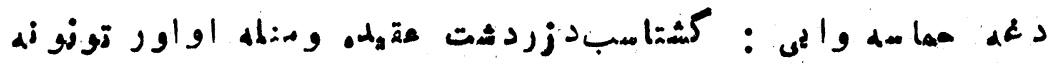

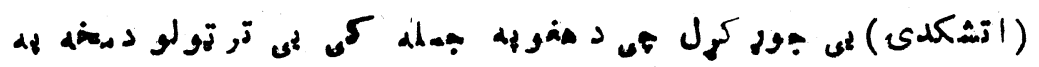

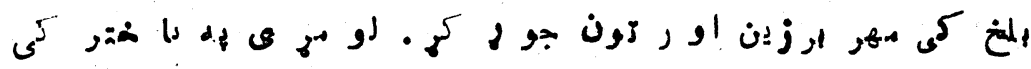

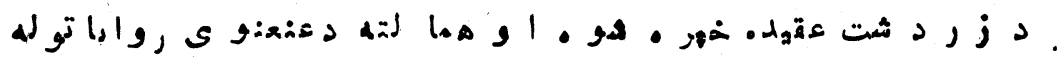

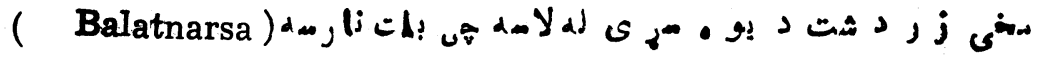

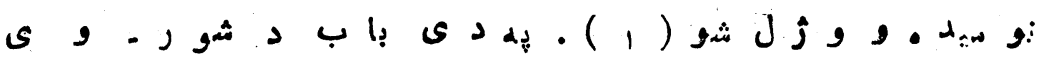

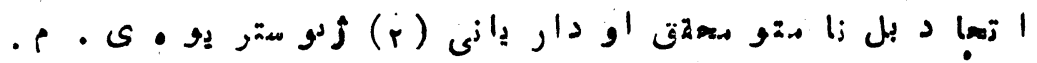

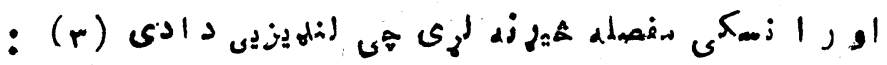

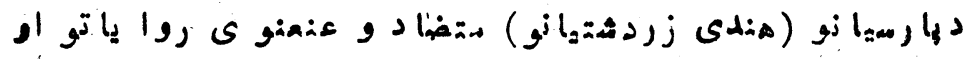

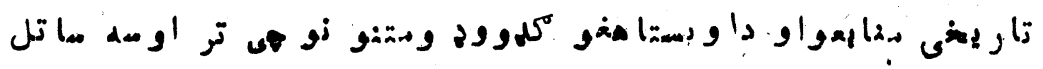

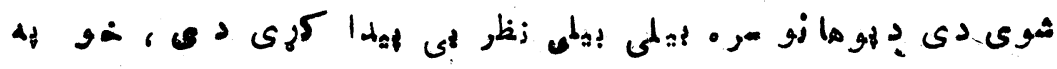

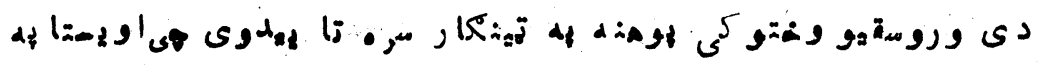

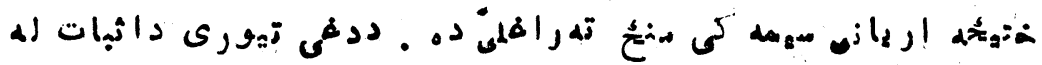

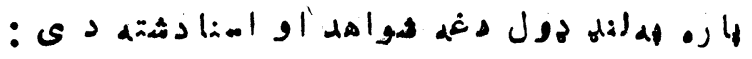

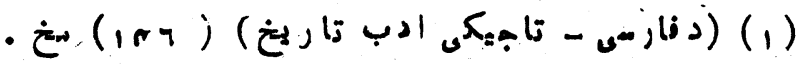

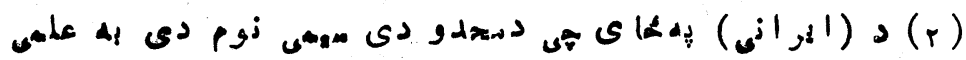

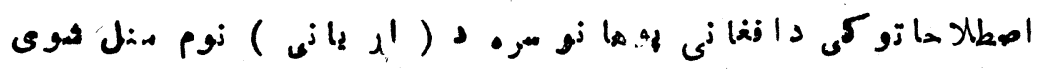

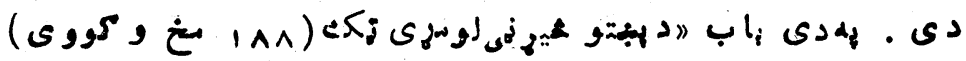

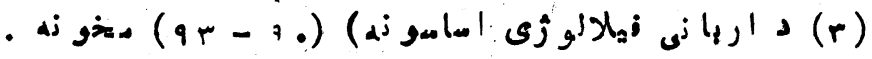


$-1 r-$

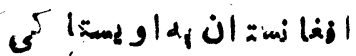

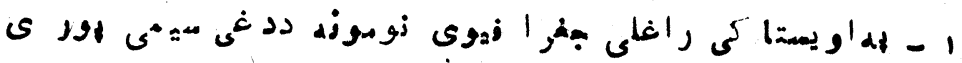

- 1

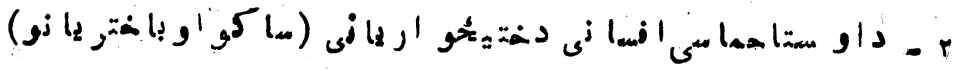

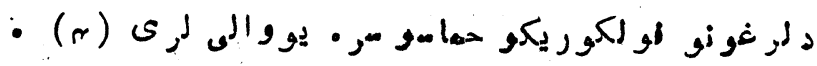

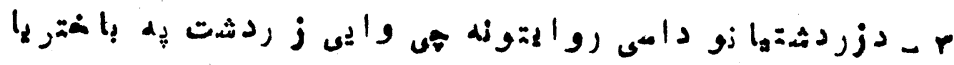

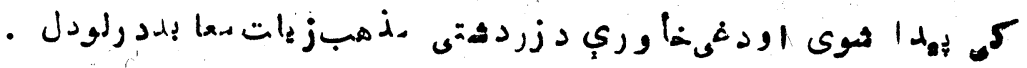

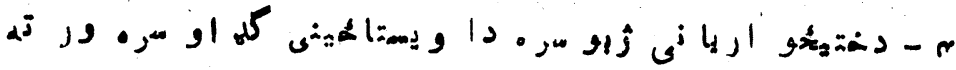

- خموصودات

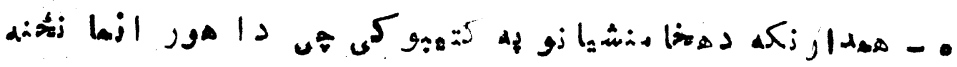

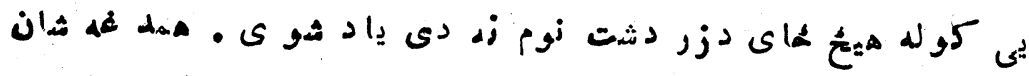

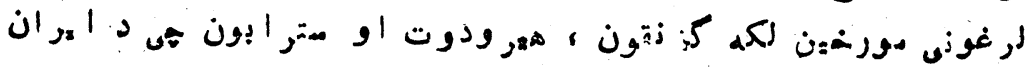

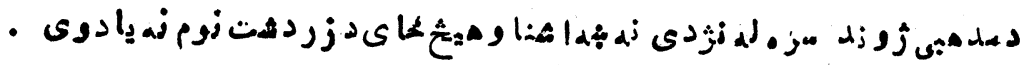

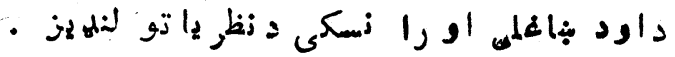

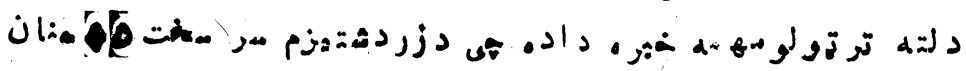

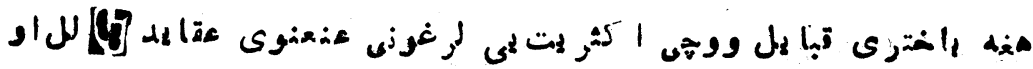

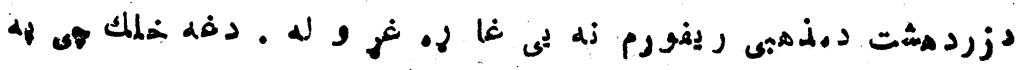

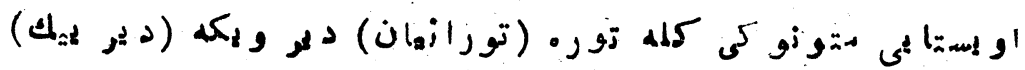

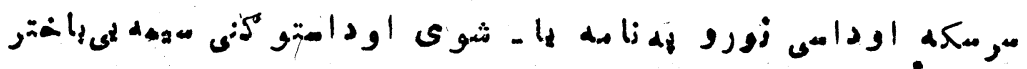

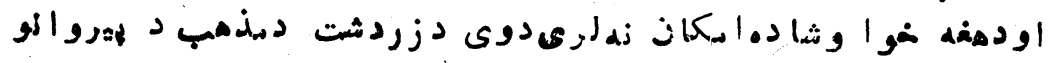

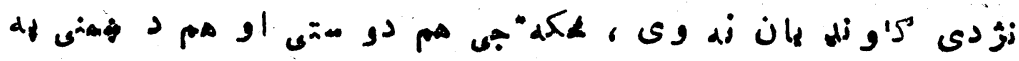

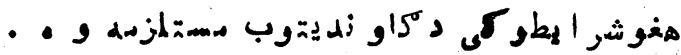

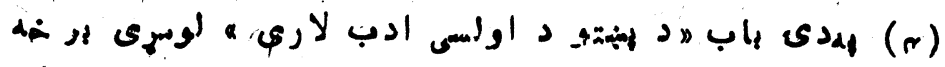

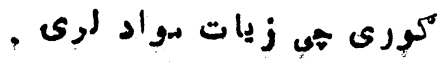


¿ll?

$-1 m-$

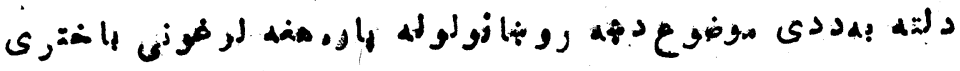

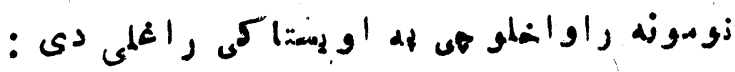

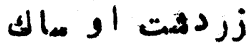

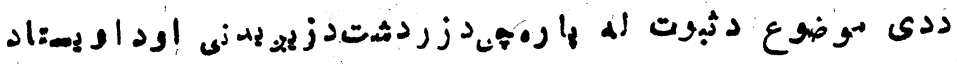

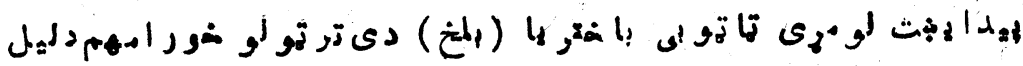

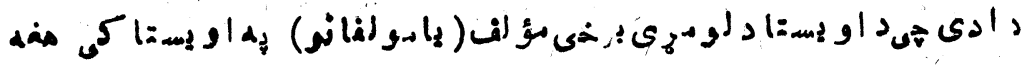

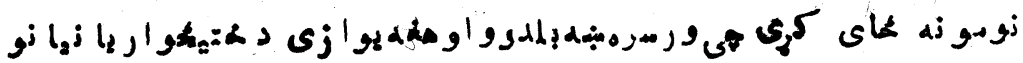

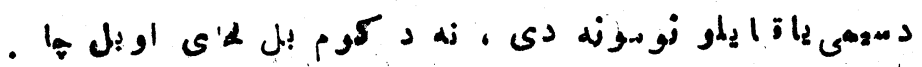

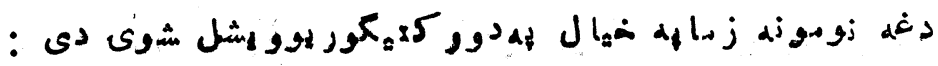

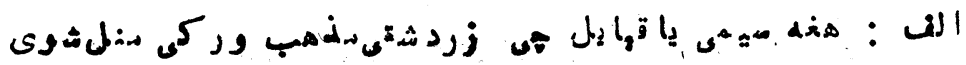

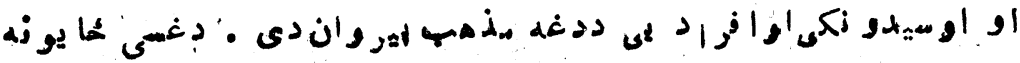

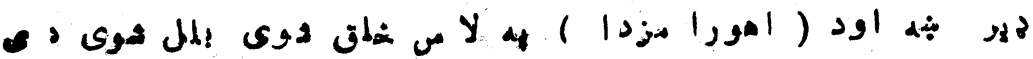

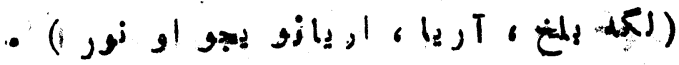

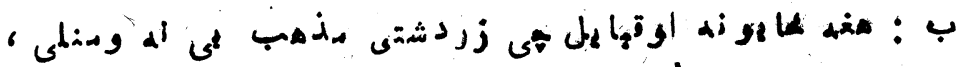

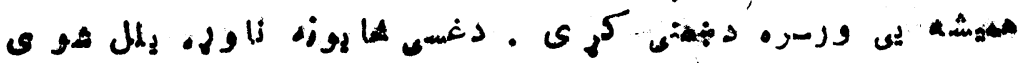

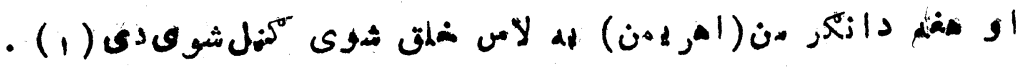

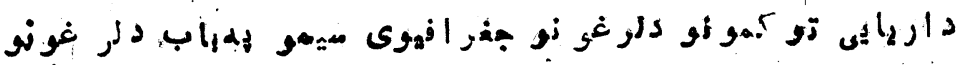

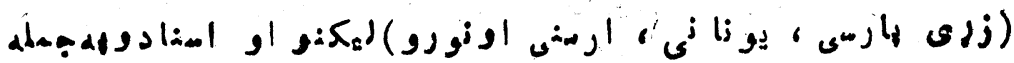

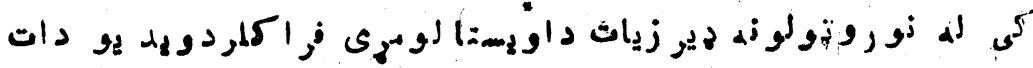

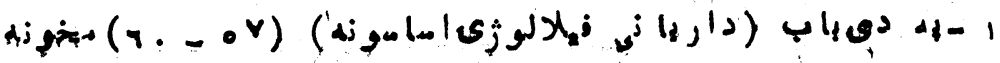

- $v$, 
$-10-$

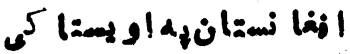

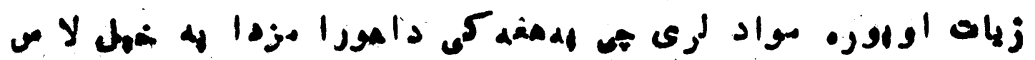

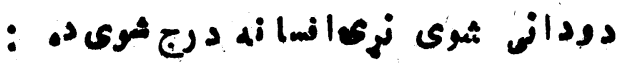

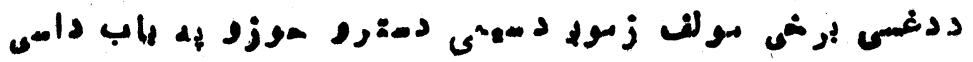

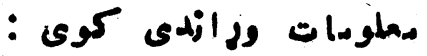

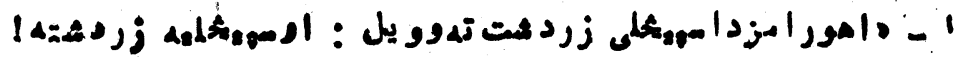

ale

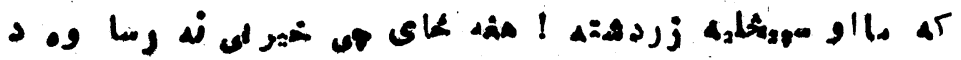

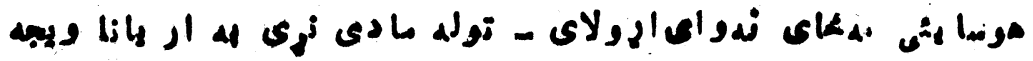

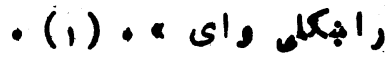

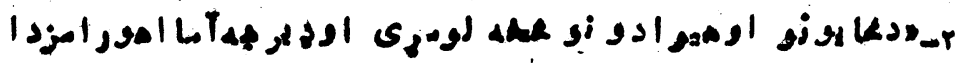

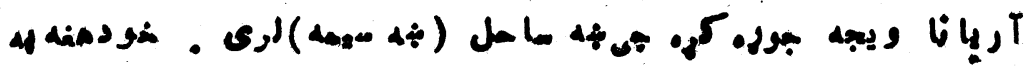

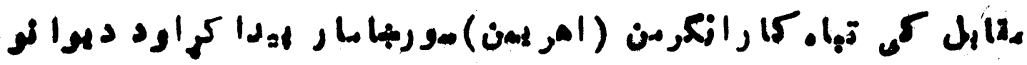

- (r) (

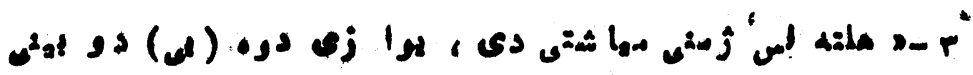

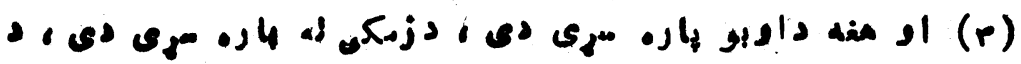

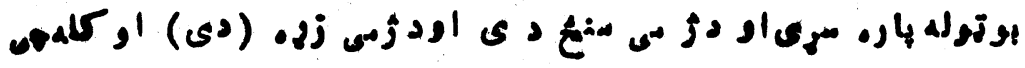

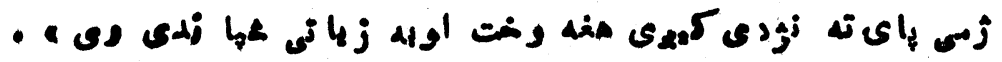

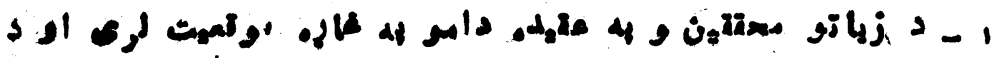

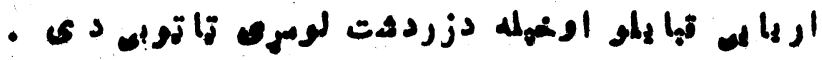

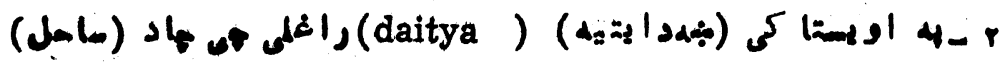

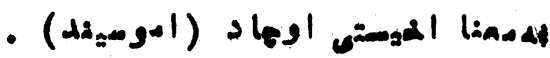

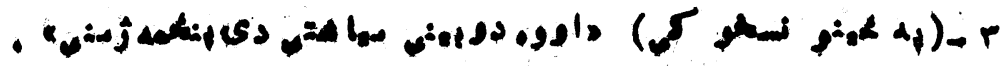




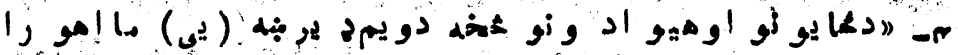

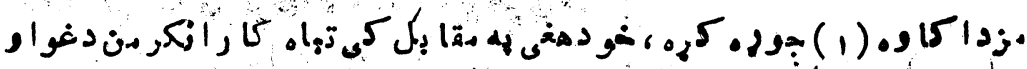

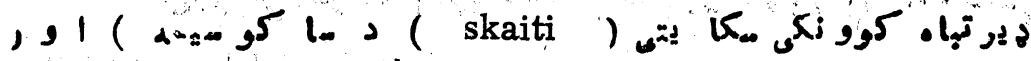

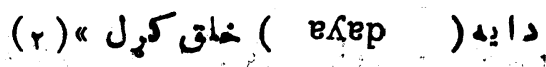

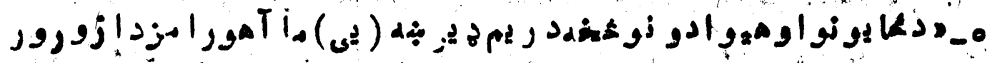

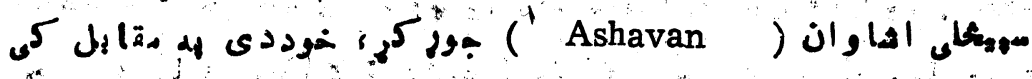

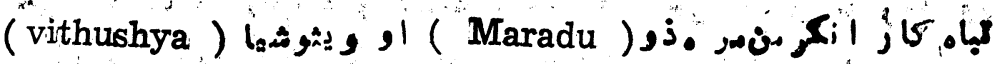

$$
\text { . }
$$

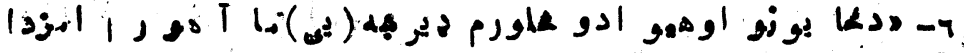

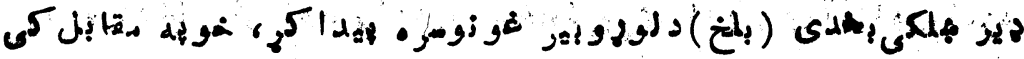

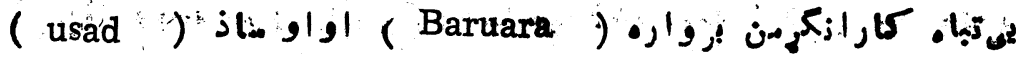

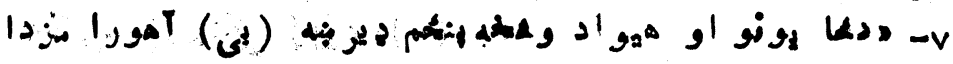

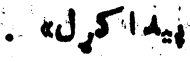

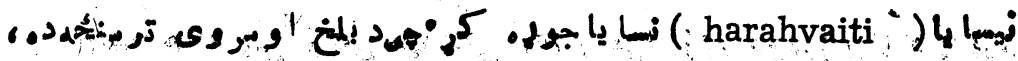

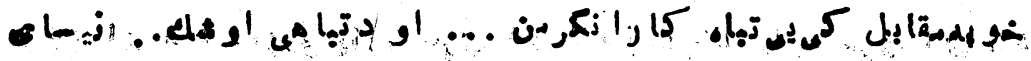

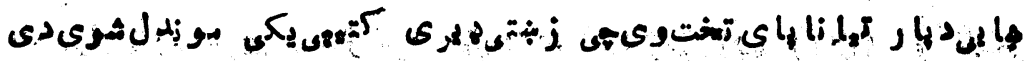

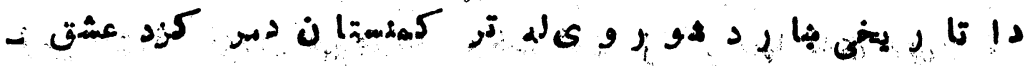

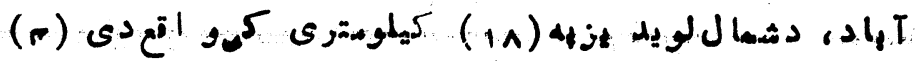

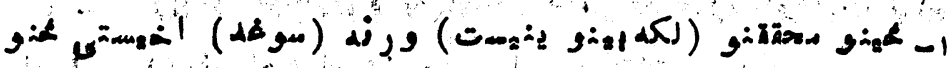

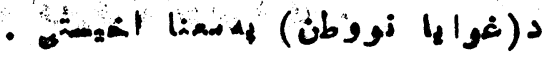

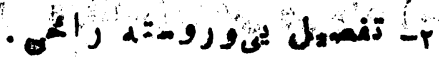
•

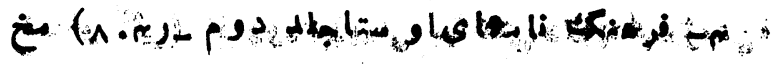


$-1 v-$

|

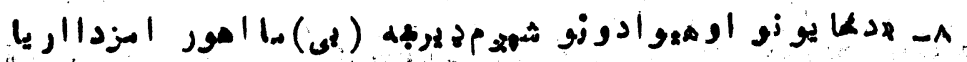

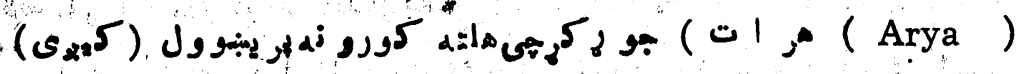

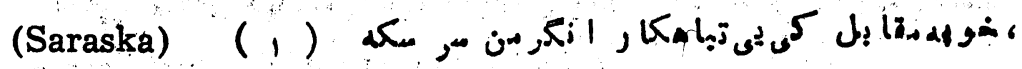

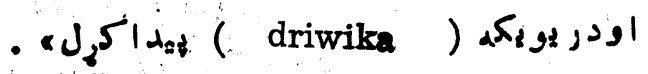

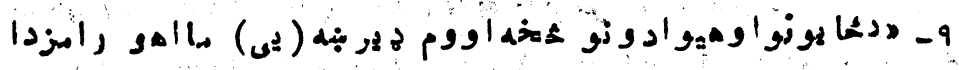

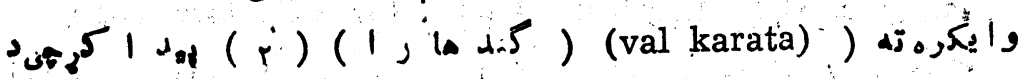

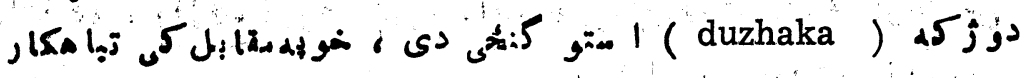
a)

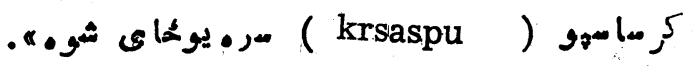

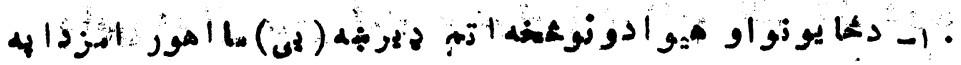

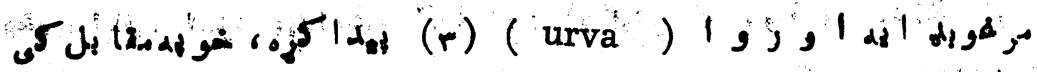

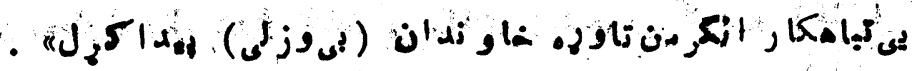

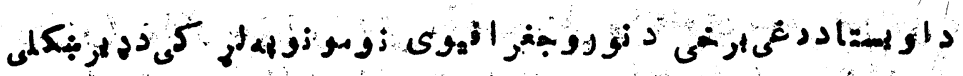

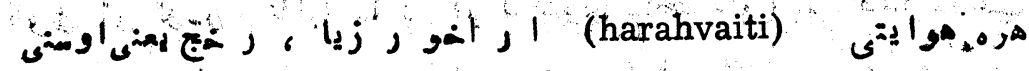

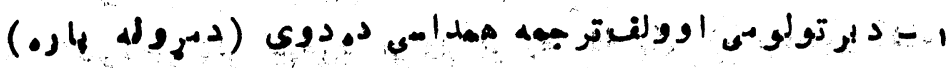

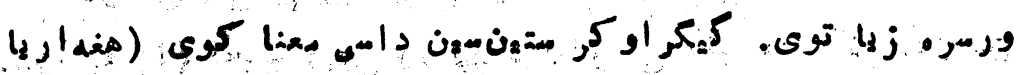

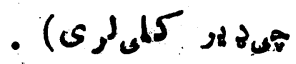

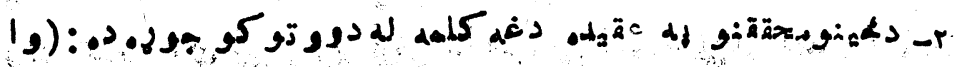

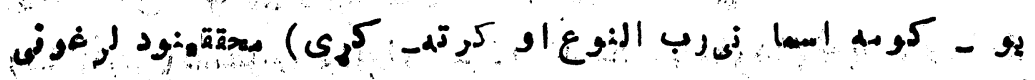

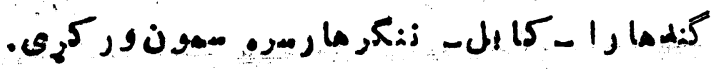

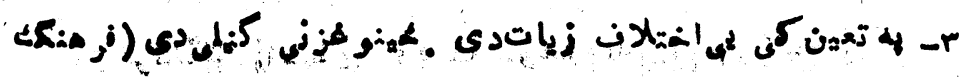

( 
id:

$-1 A$

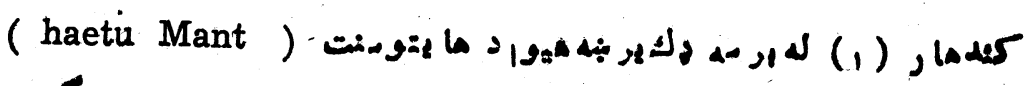

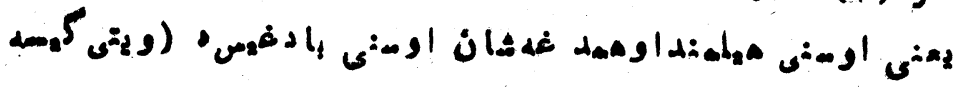
(

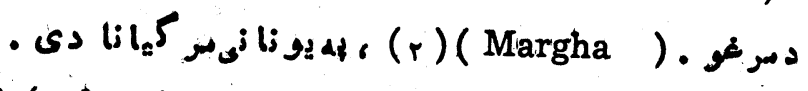

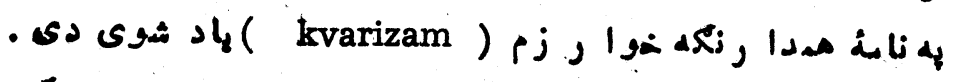

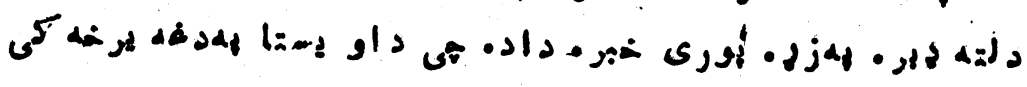

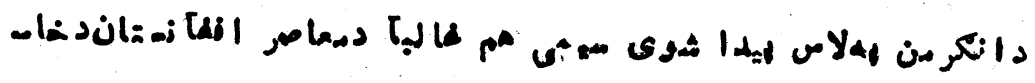
م رى أرخى دأ

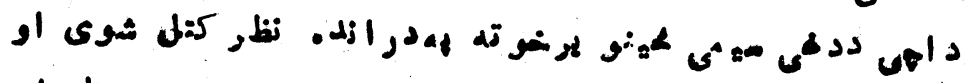

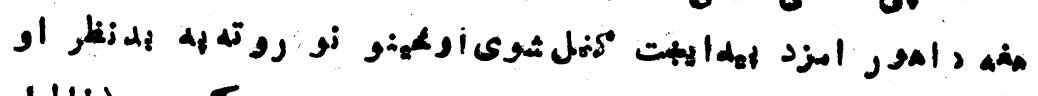

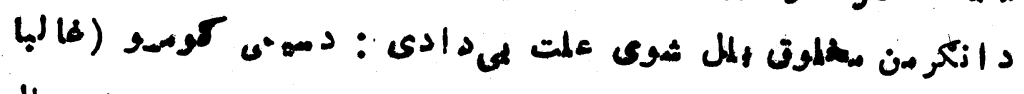

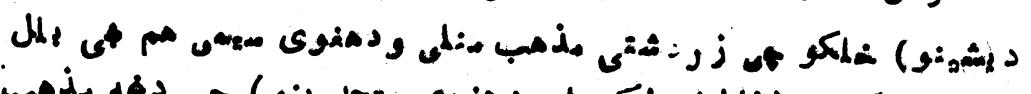

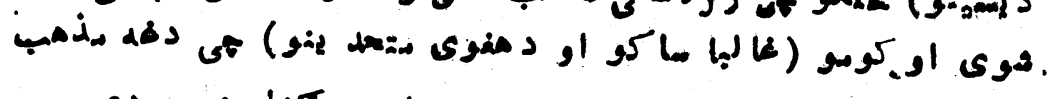

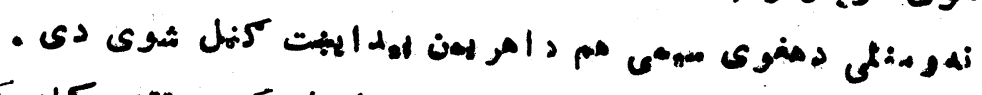

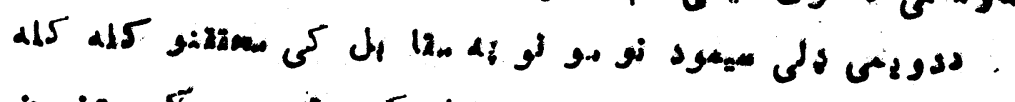

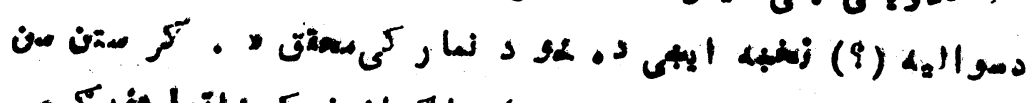
(Christen sen)

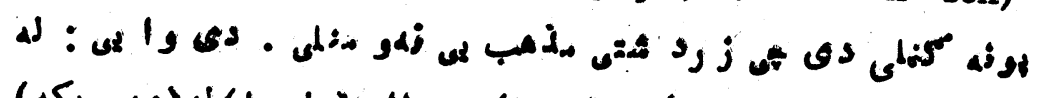

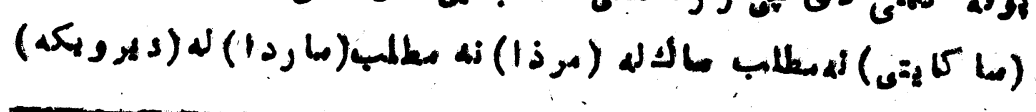

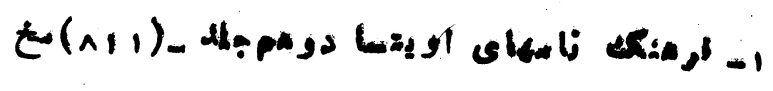

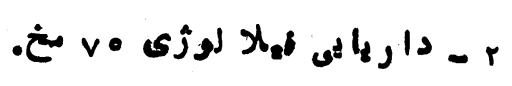


$-19-$

|

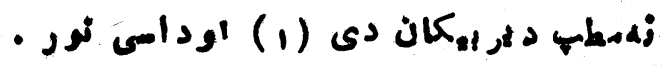

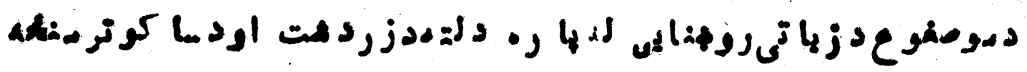
-

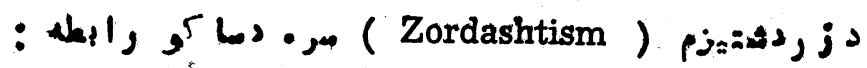

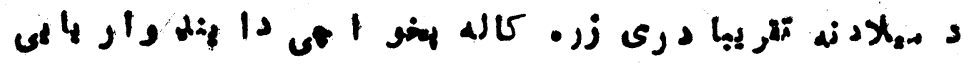

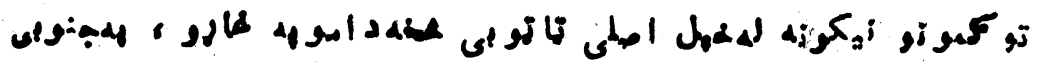

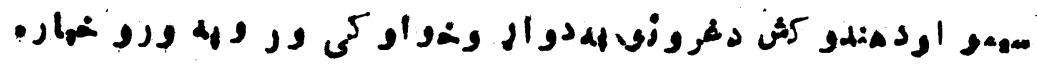

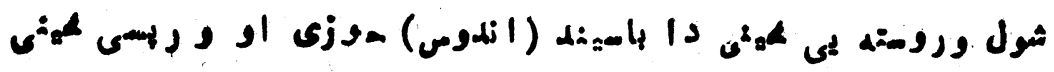

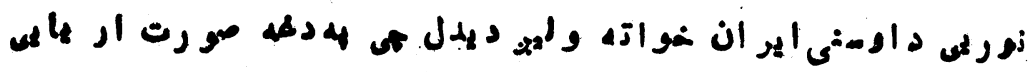

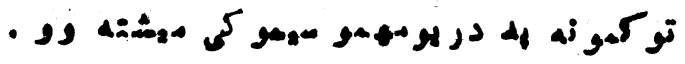

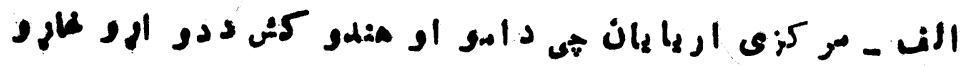
- له

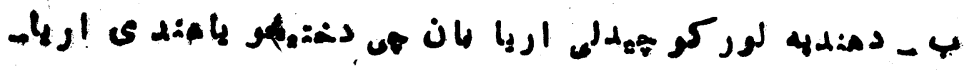

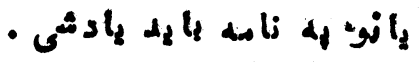

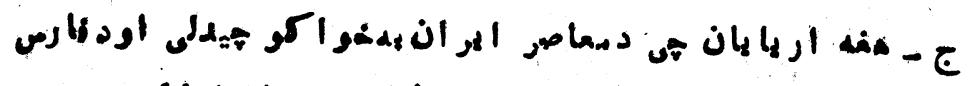

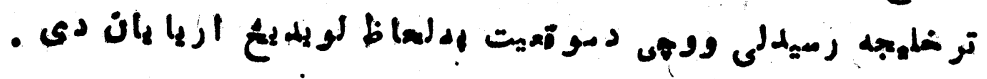

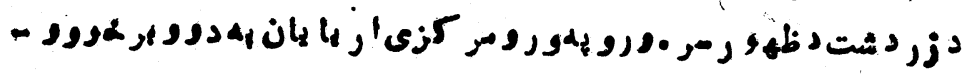
:

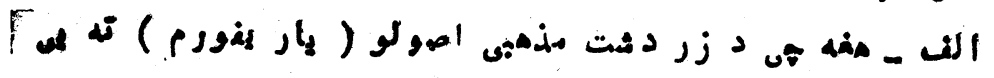

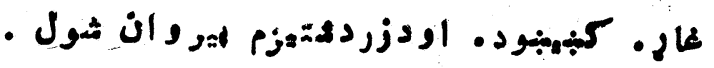

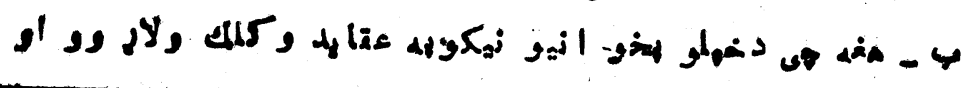
- 


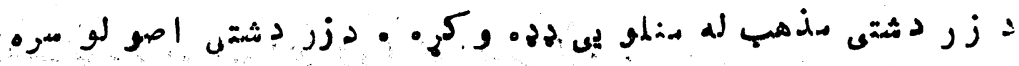

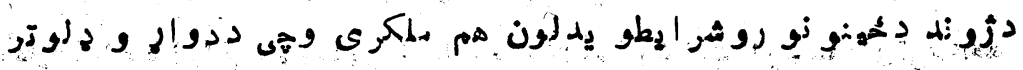

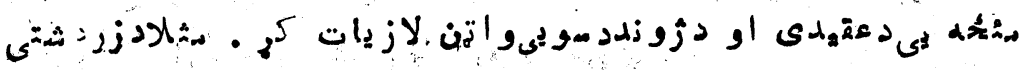

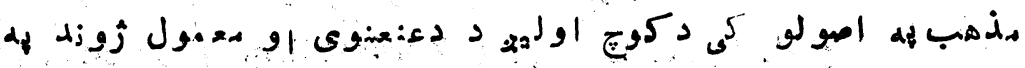

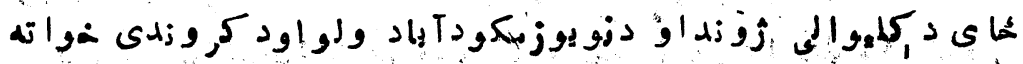

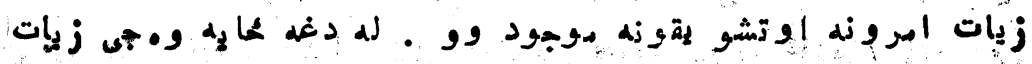

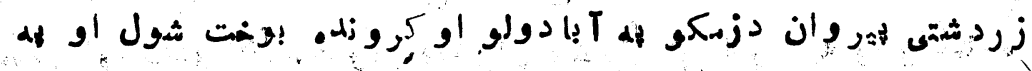

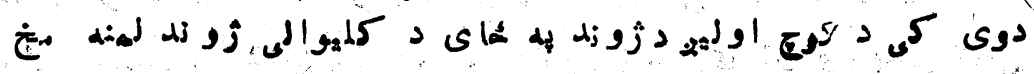

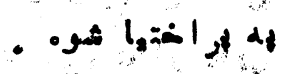

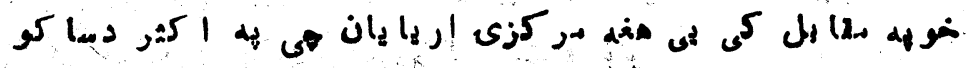

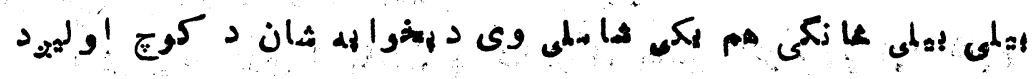

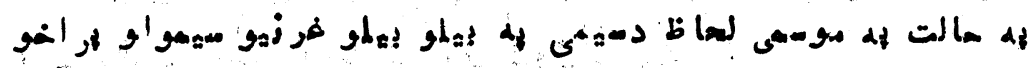

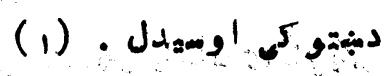

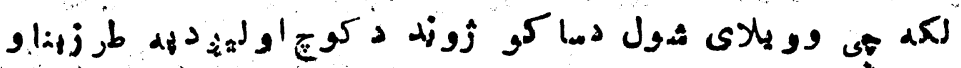

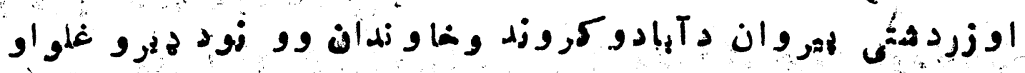

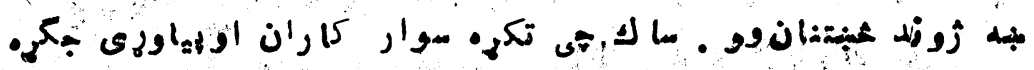

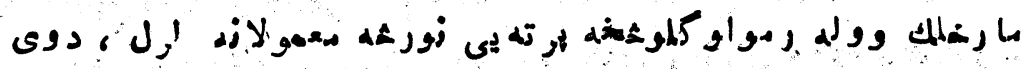

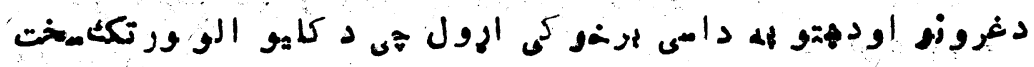

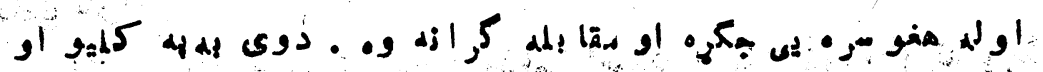

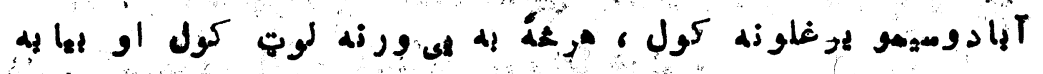

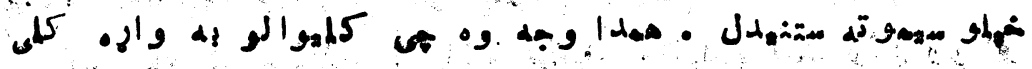

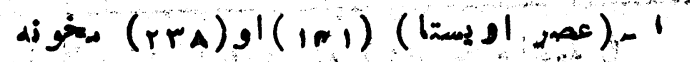




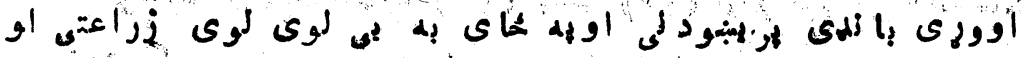

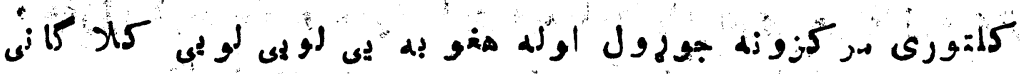

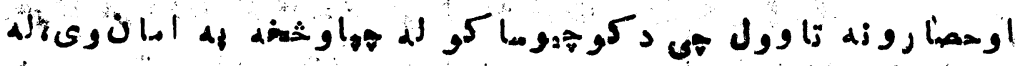

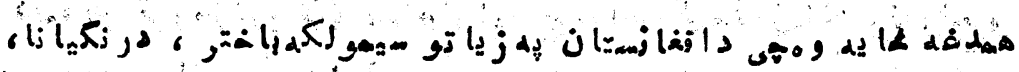

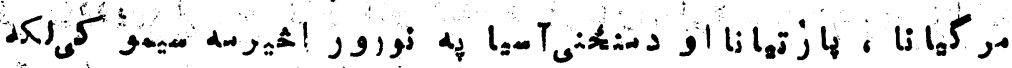

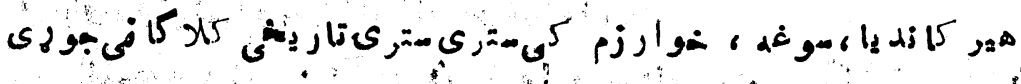

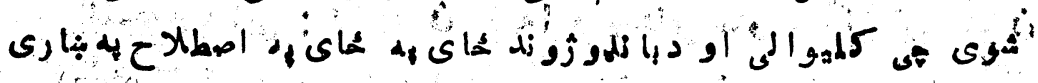

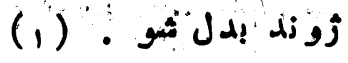

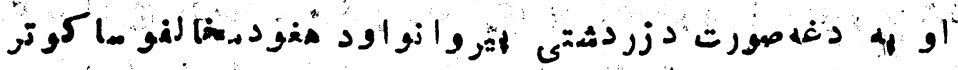

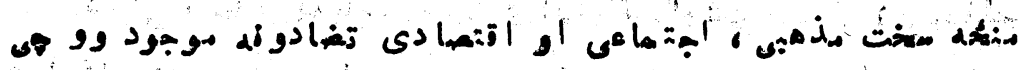

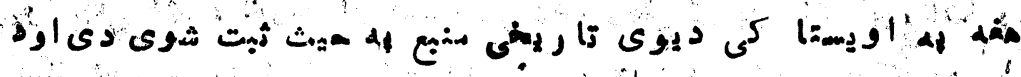

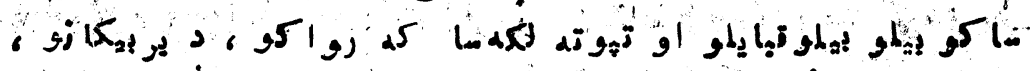

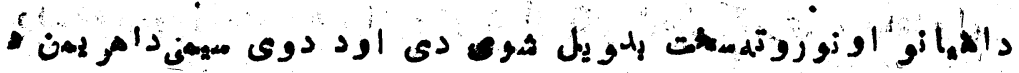

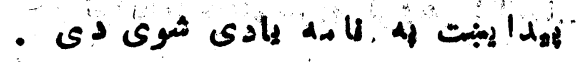

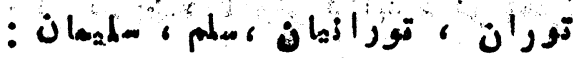

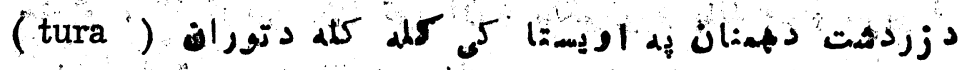

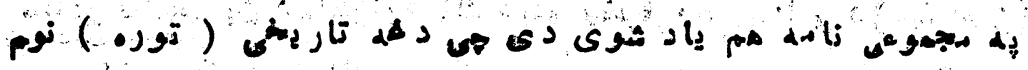

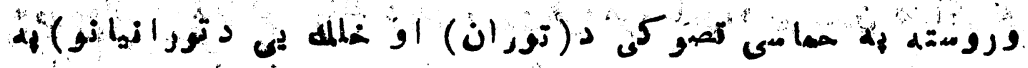

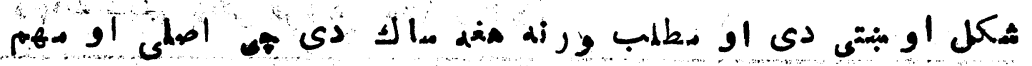

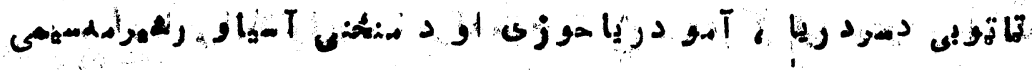

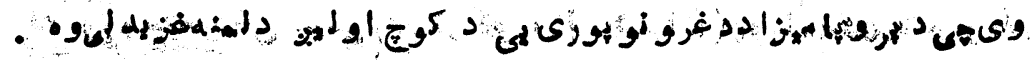

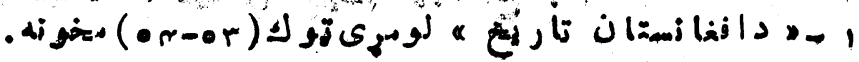




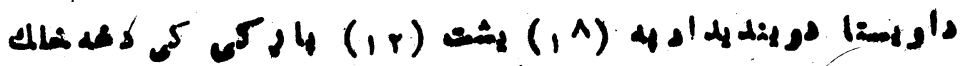

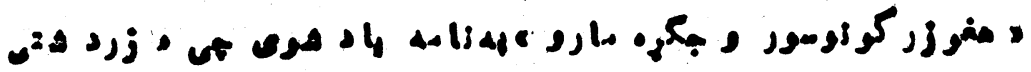

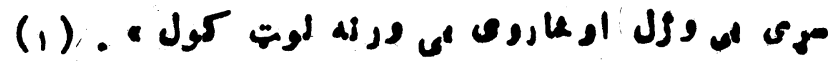

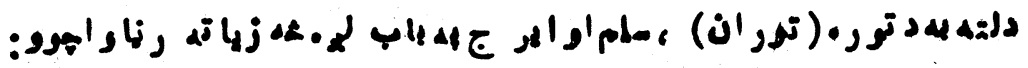

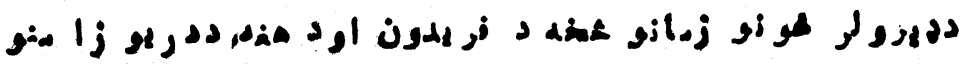

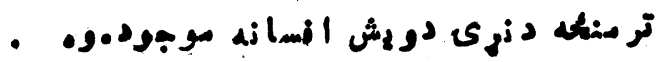

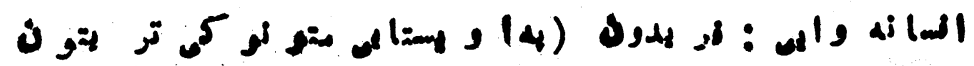
(1) (Treton)

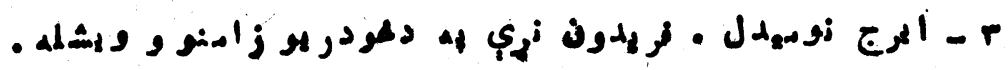

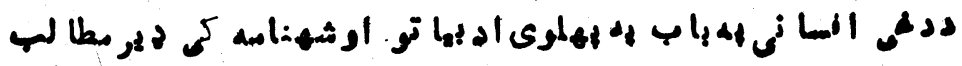

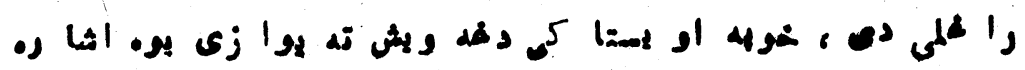

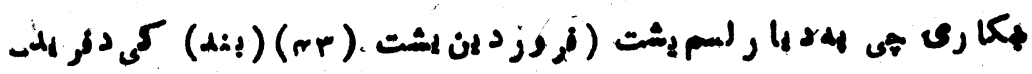

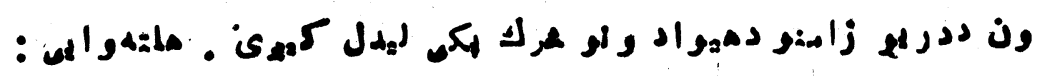

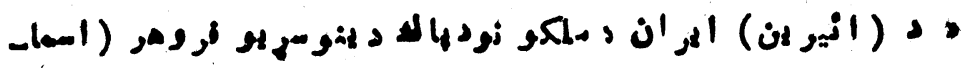

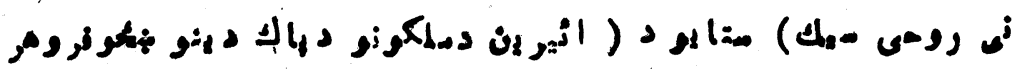

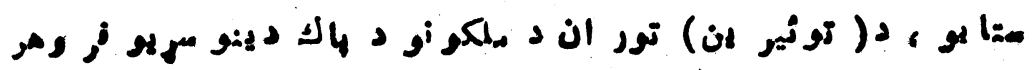

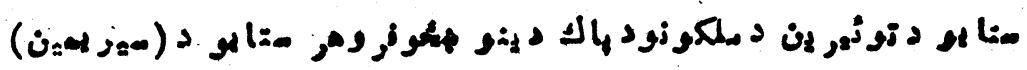

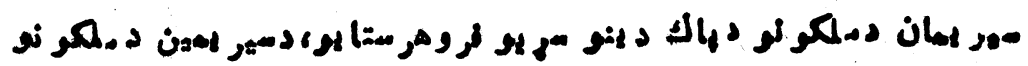

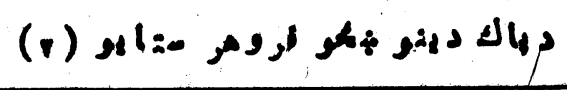

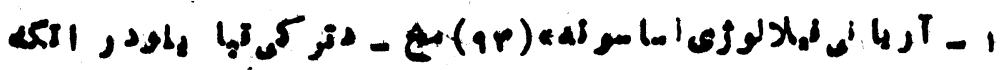

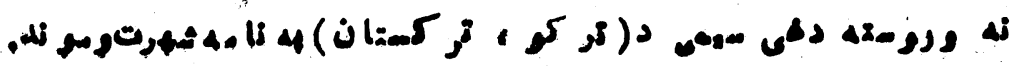

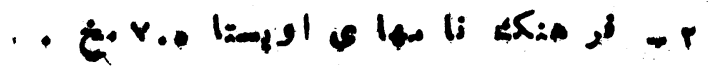


-rro

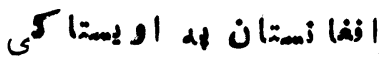

ه تحقة"

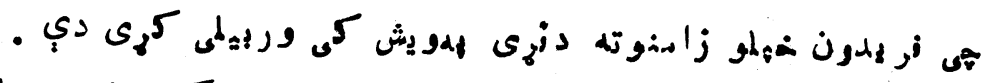

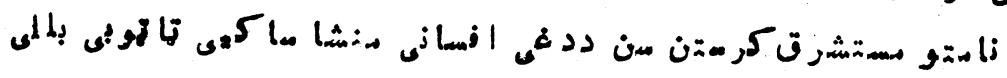

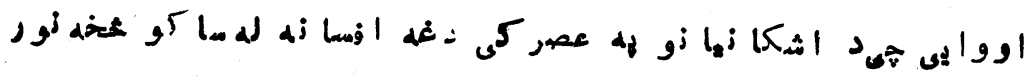

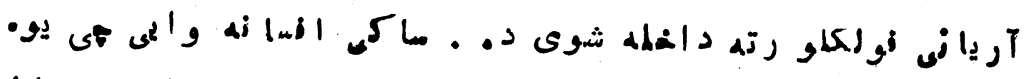

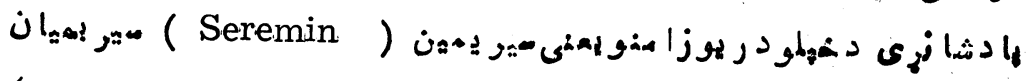

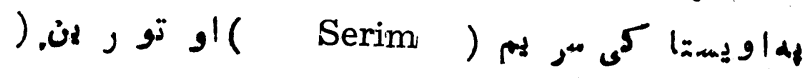

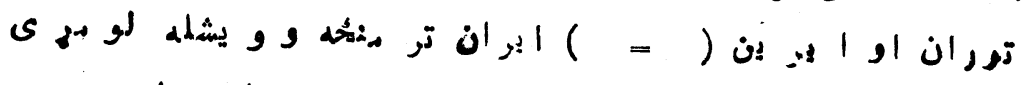

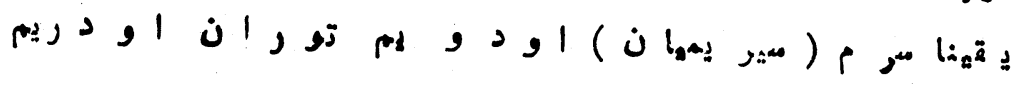

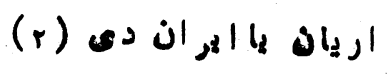

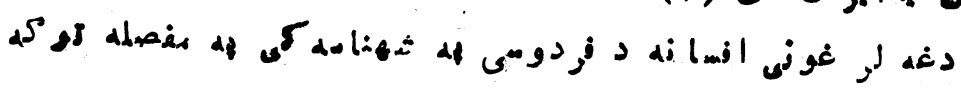

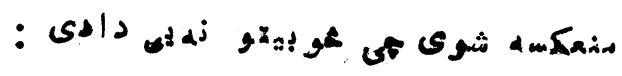
زئه

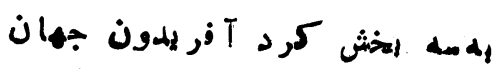

年

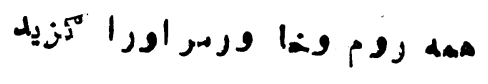

:

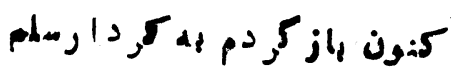

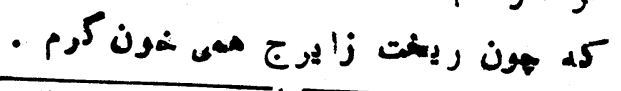

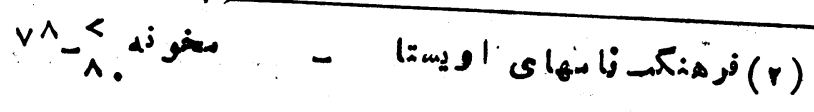


غй

$-r m-$

年

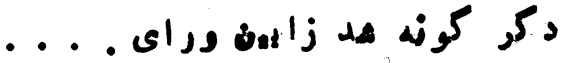

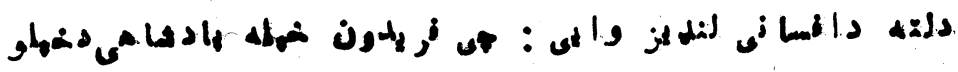

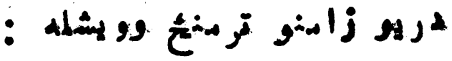

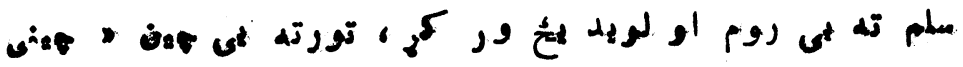

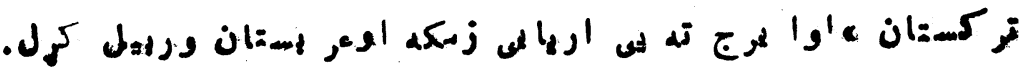

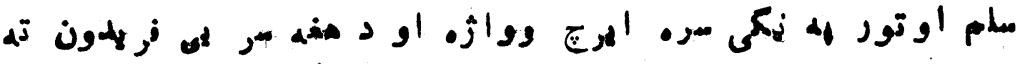

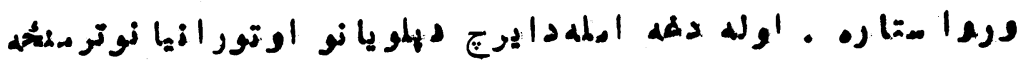

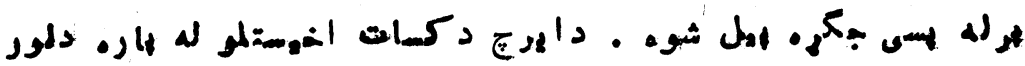

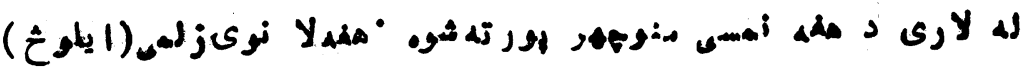

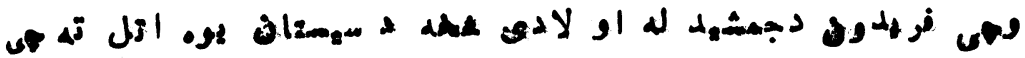

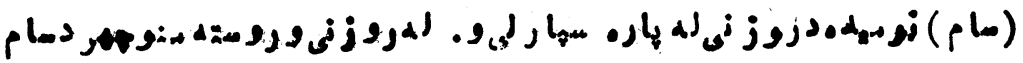

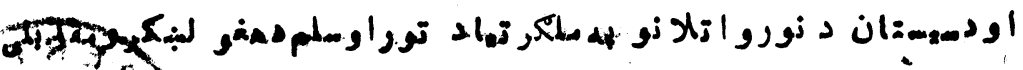

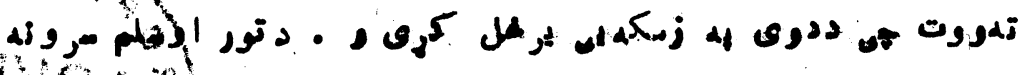

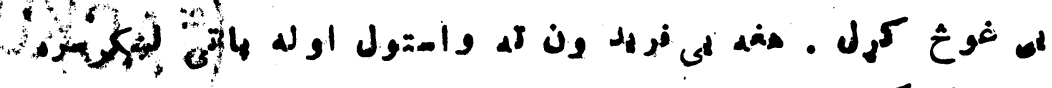
(1)

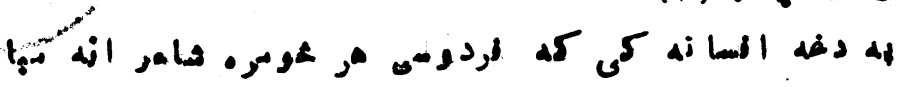

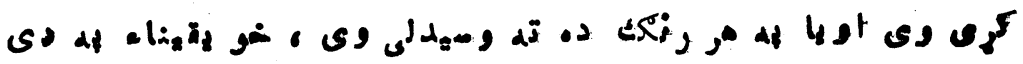

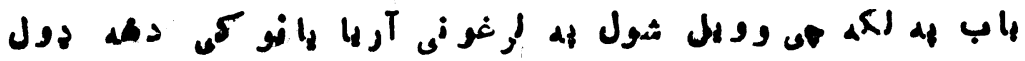

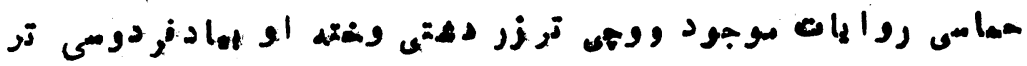

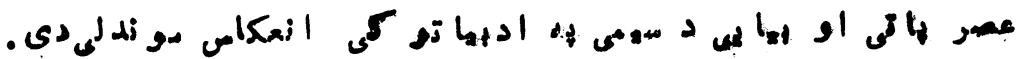

- . 
-ro -

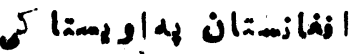

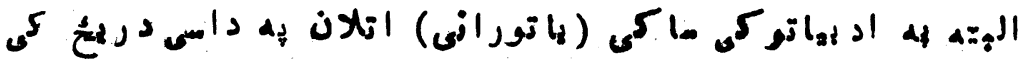

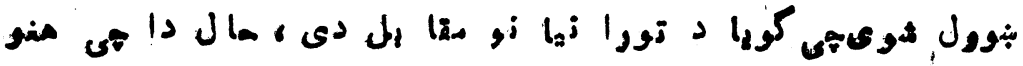

- N v

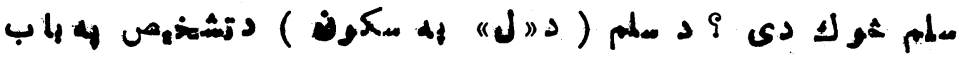
م-

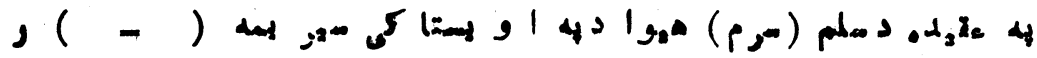

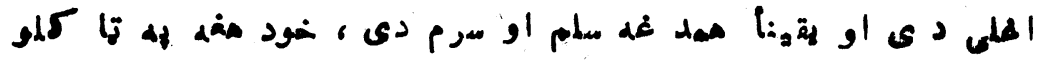

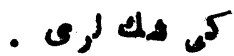

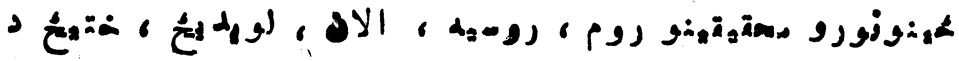

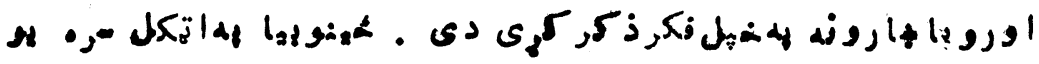

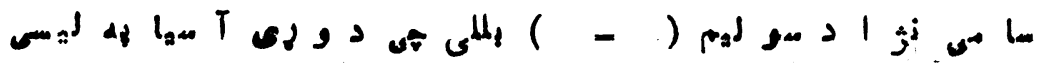

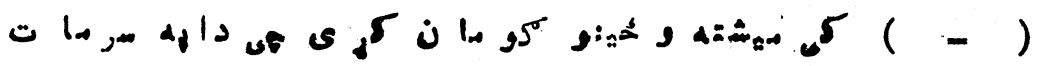

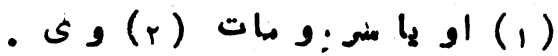

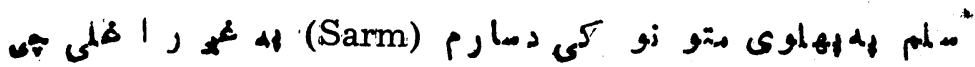

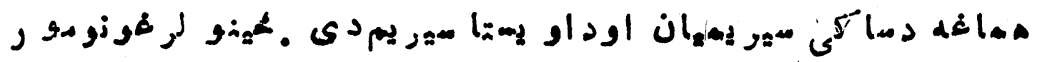

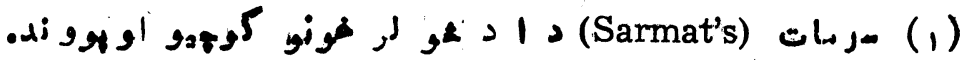

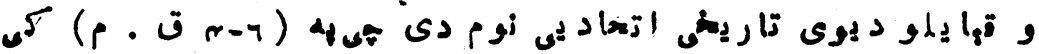

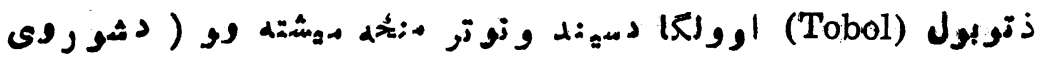

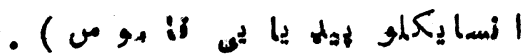

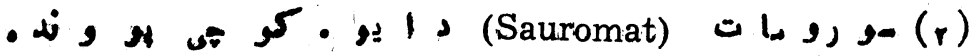

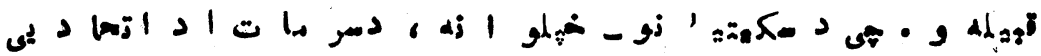

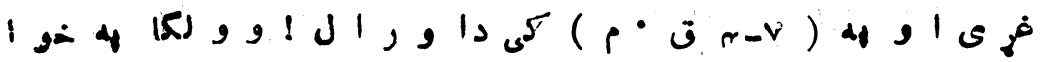

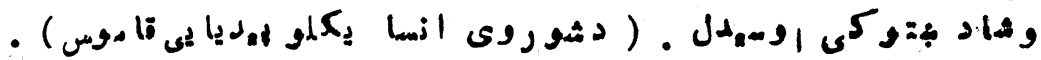


dit

$-r y-$

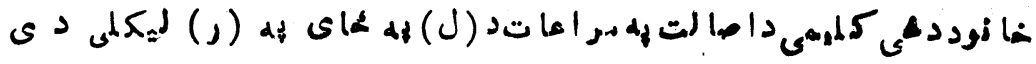

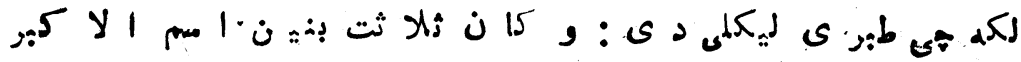

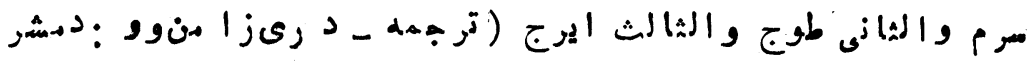

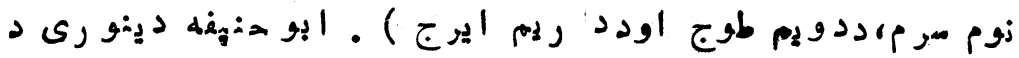

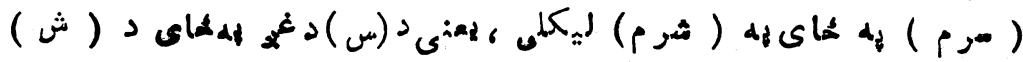
ف

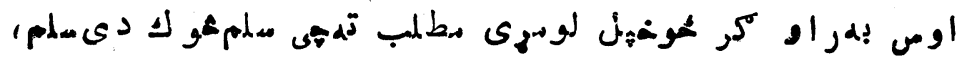

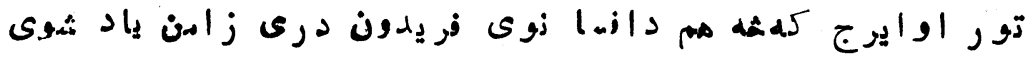

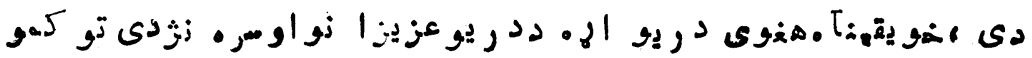

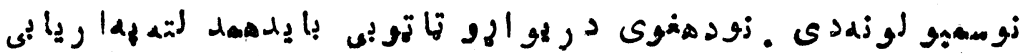

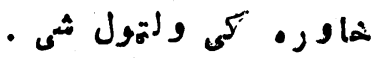

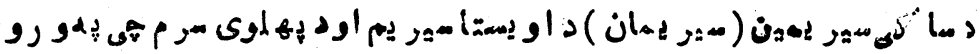

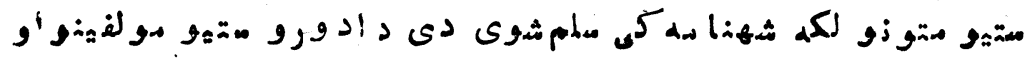

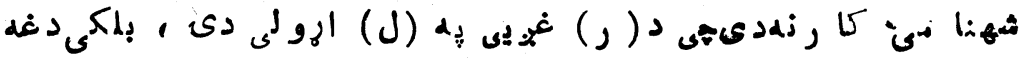

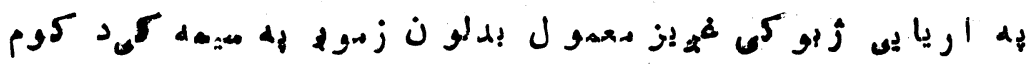

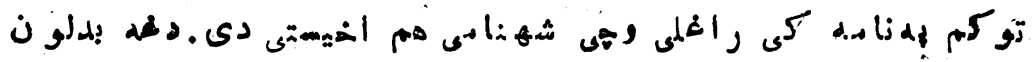

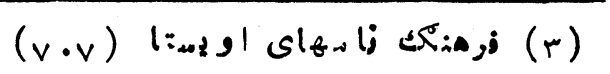

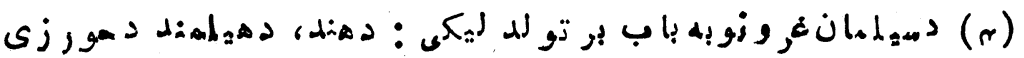

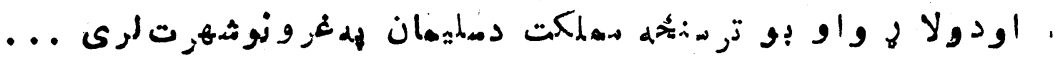

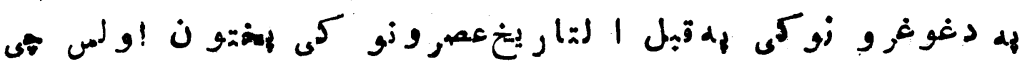

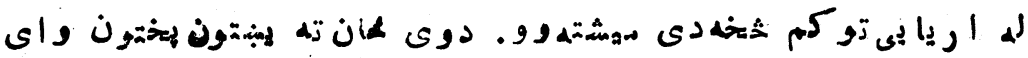

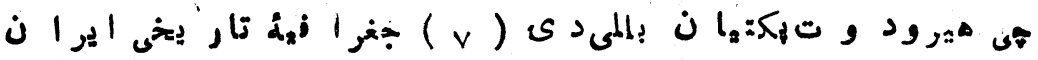

(ن) ( r.) 
arvo

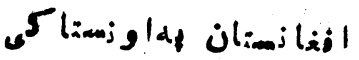

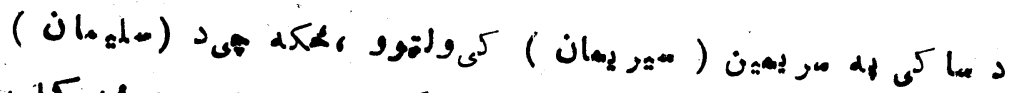

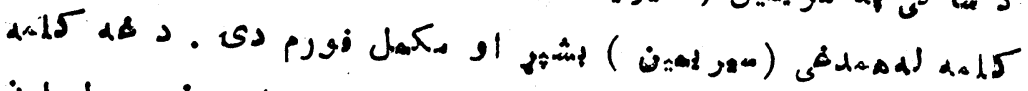

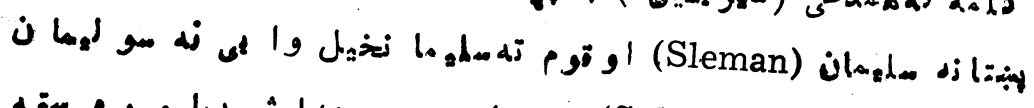

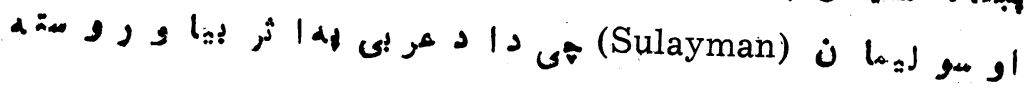

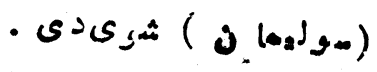

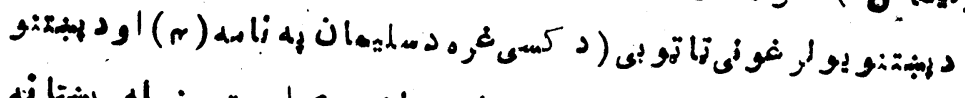

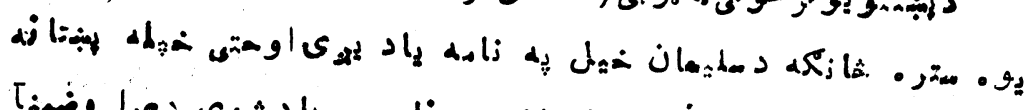

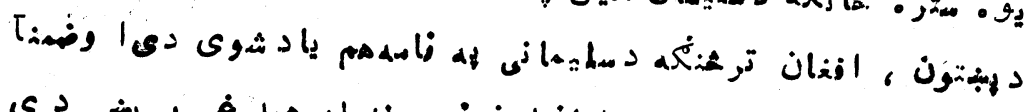

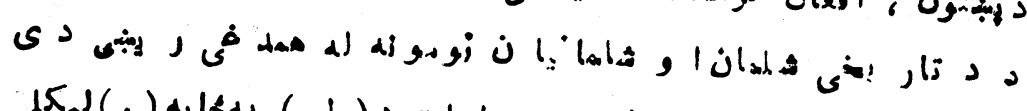

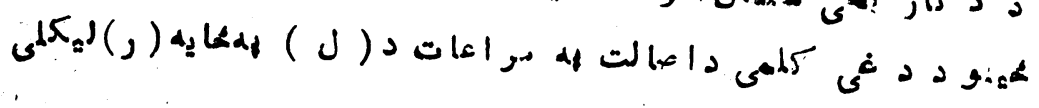

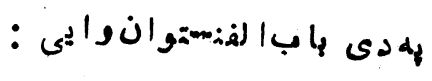

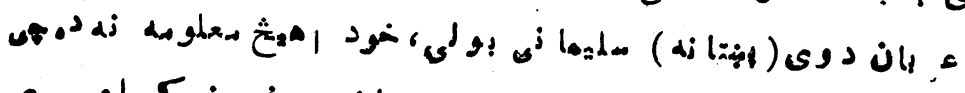

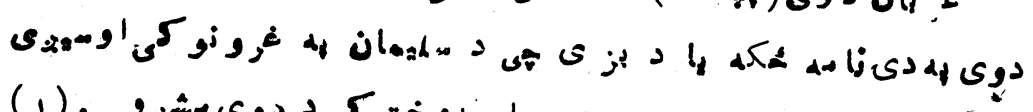

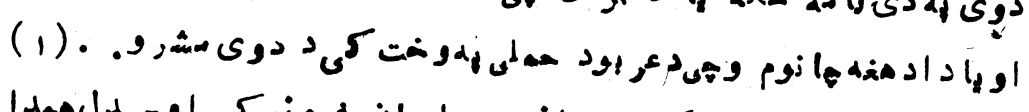

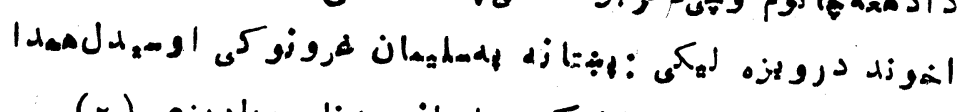

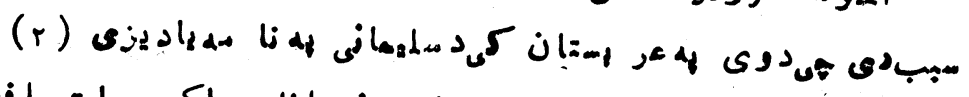

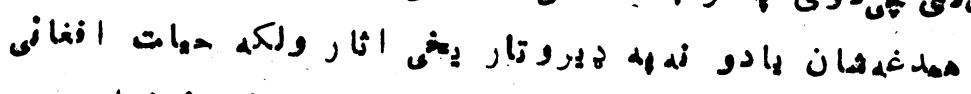

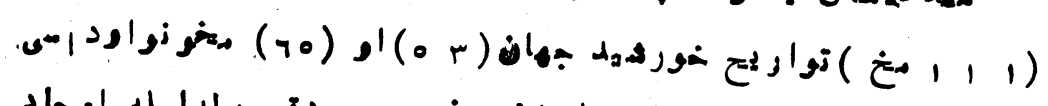

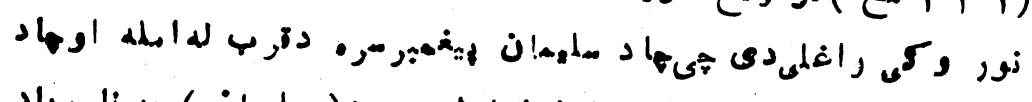

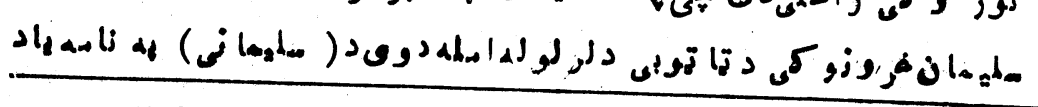

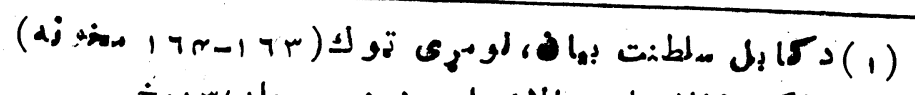

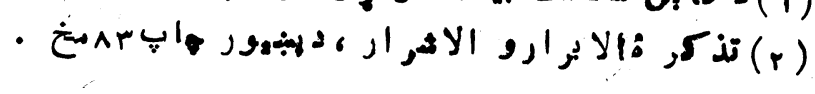


cls?

-rAD

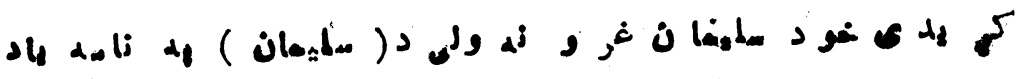

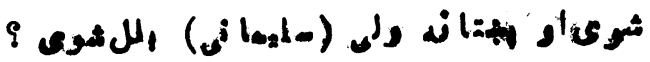

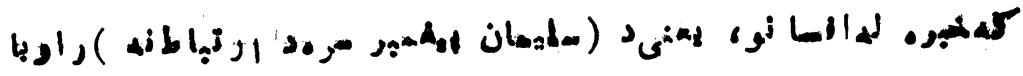

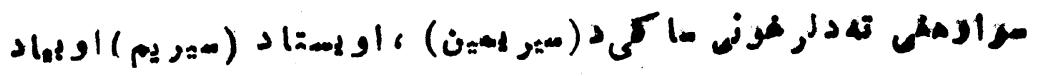

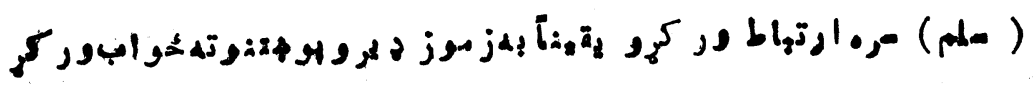

هو

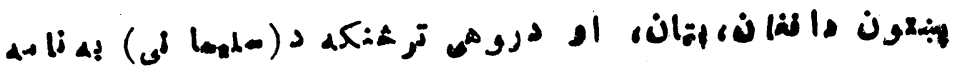

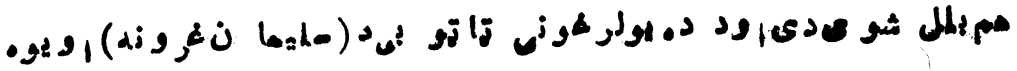

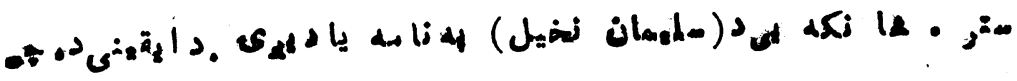

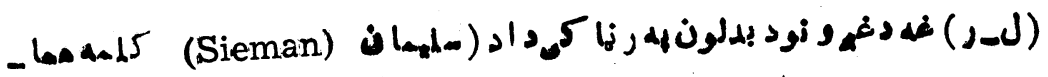

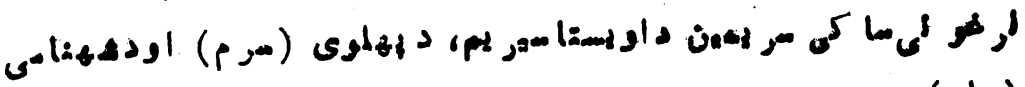

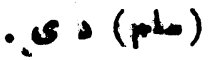

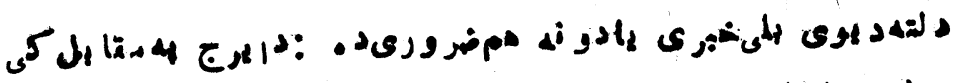

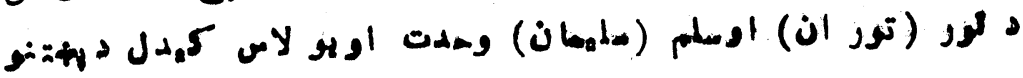

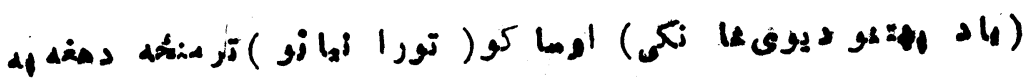

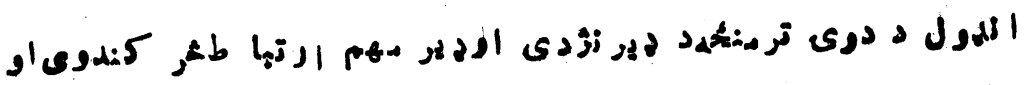

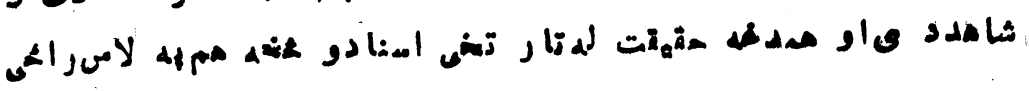

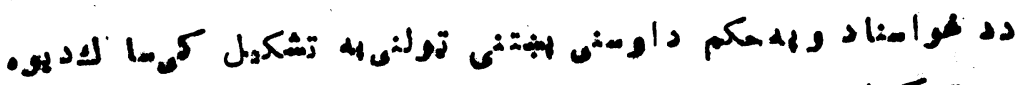

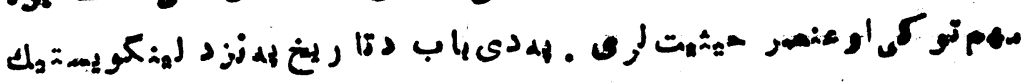

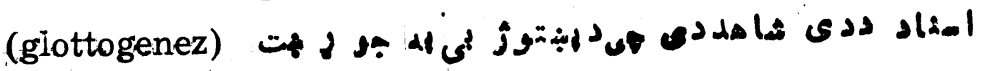




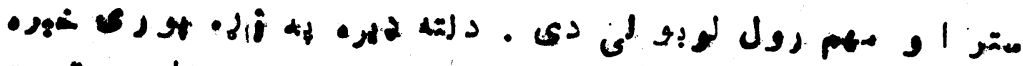

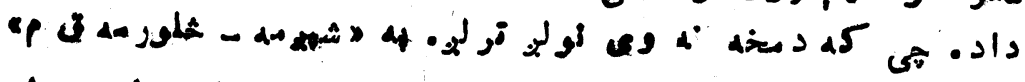

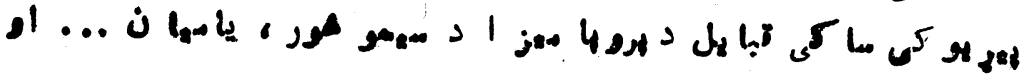

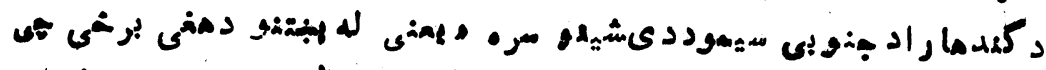

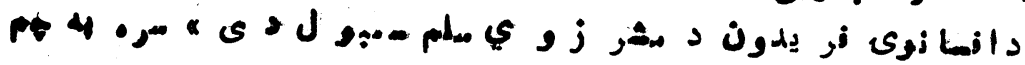

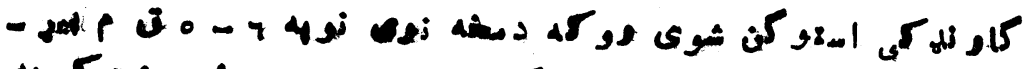

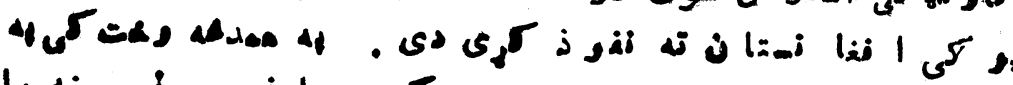

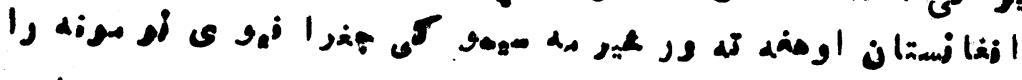

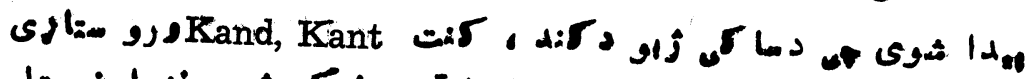

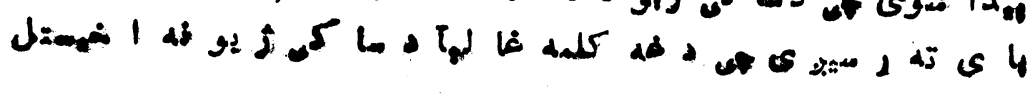
شو ى د. . 1'

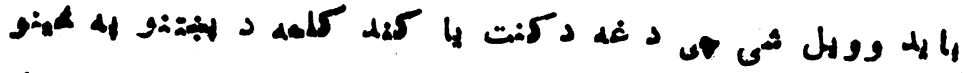

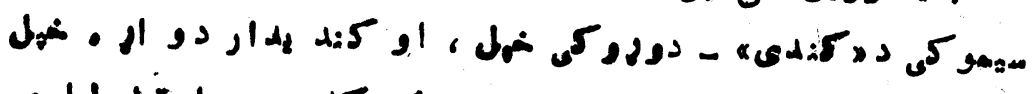

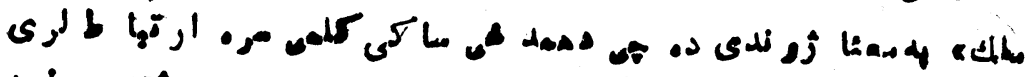

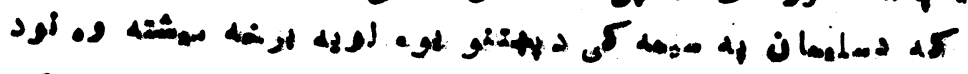

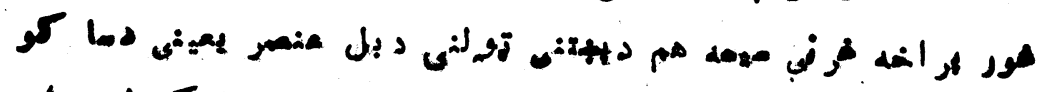

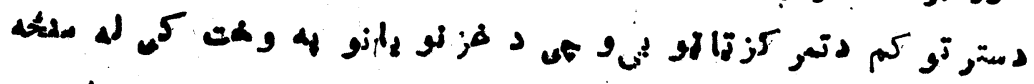

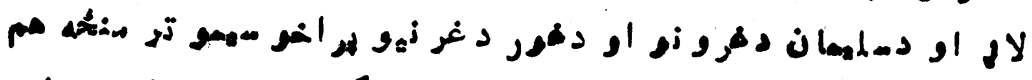

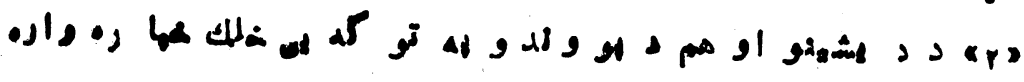
- $\int a_{a}=a^{2}$

$$
\text { - }
$$

r 


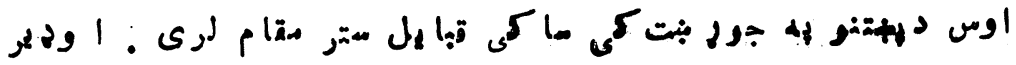

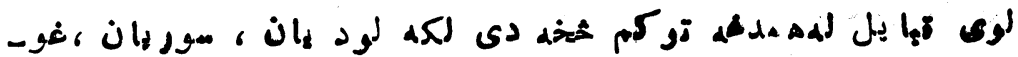

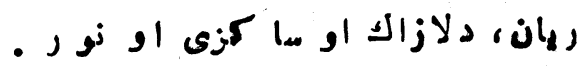

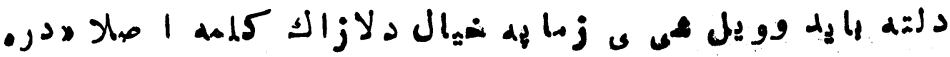

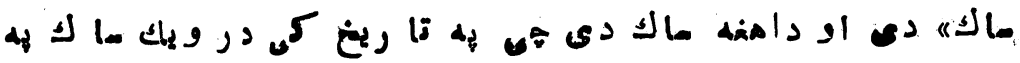

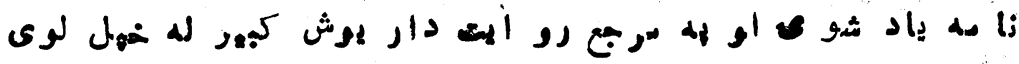

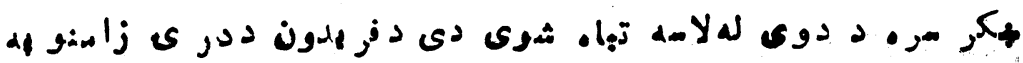

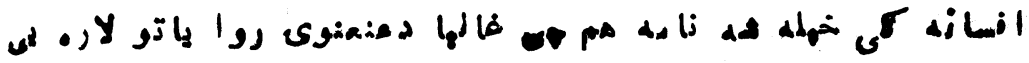

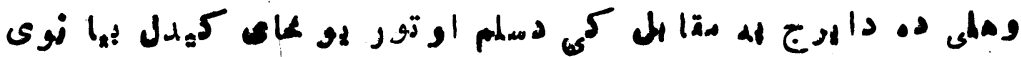

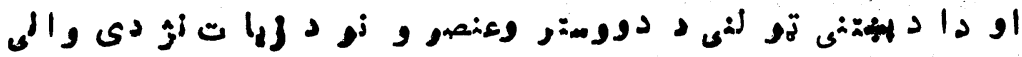

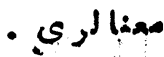

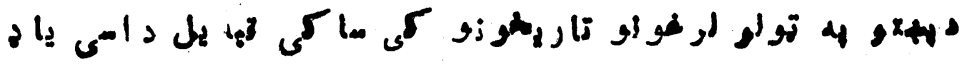

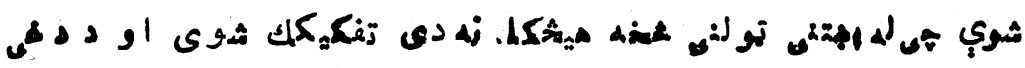

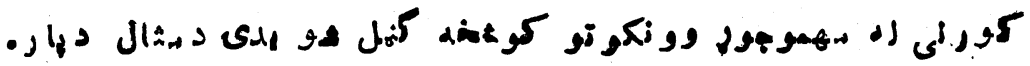

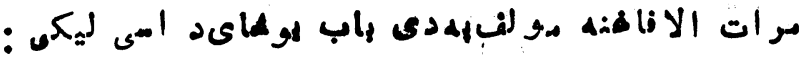

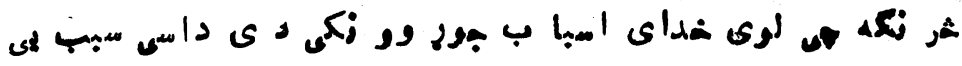

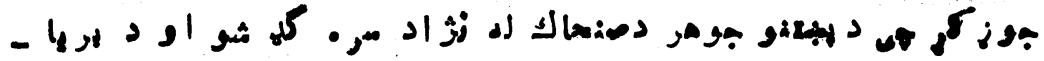

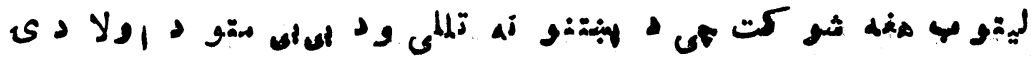


- ri -

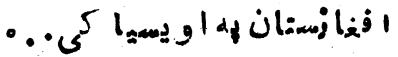

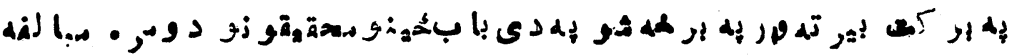

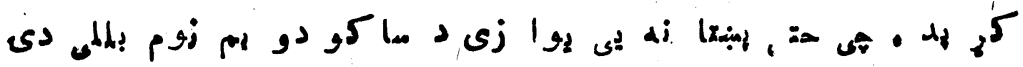
•

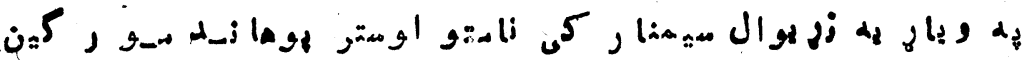

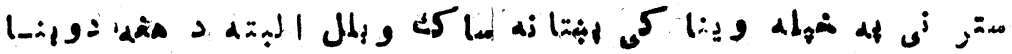

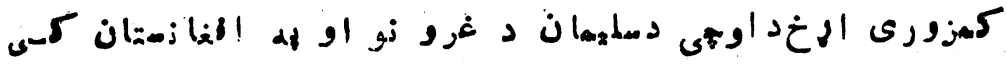

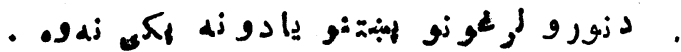

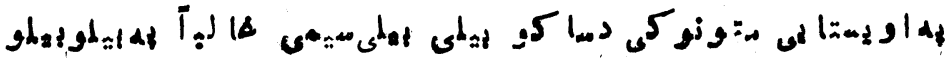

مون

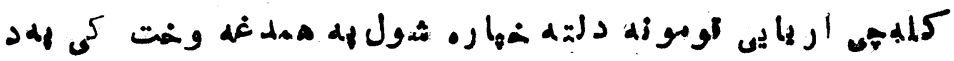

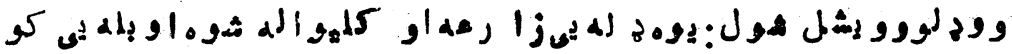

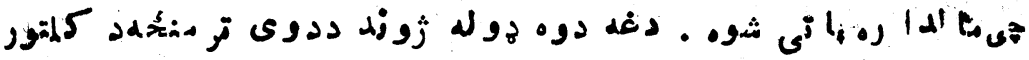

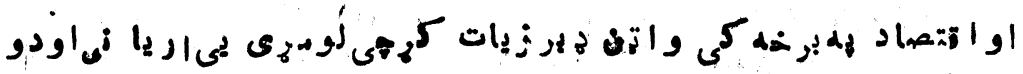

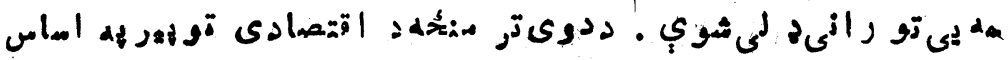

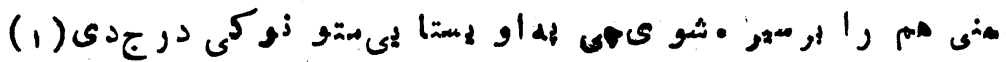

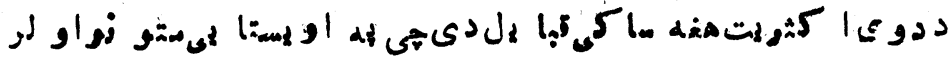

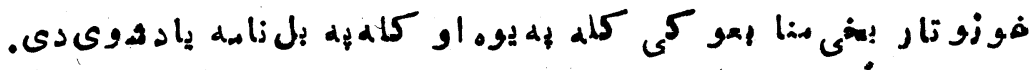

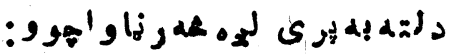

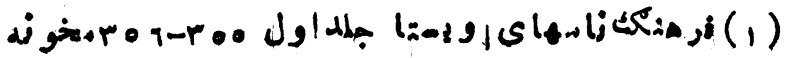




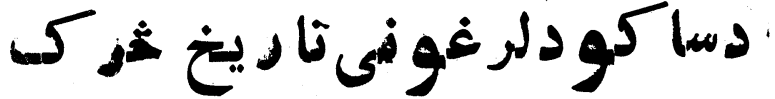

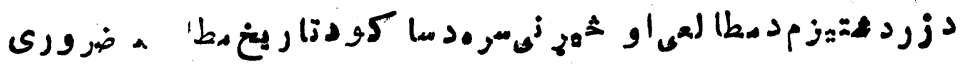

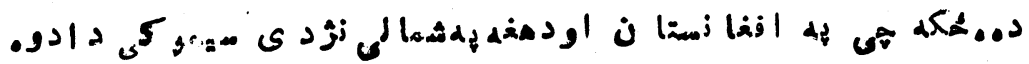

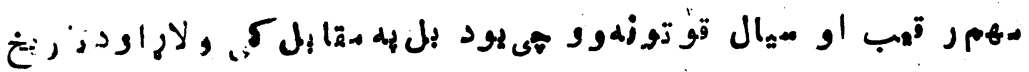

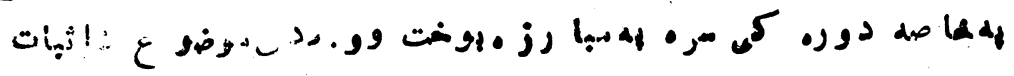

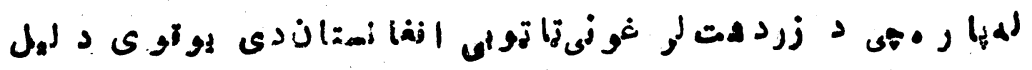

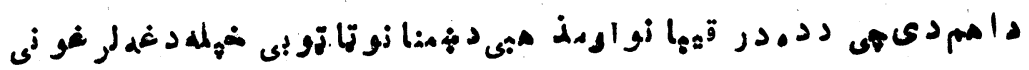

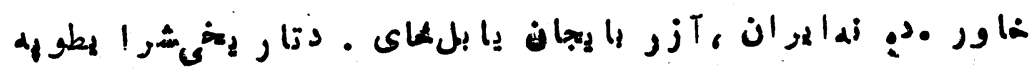

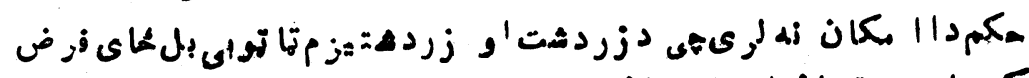

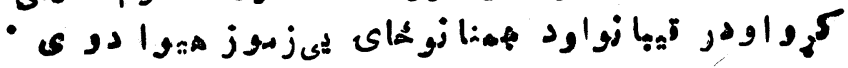

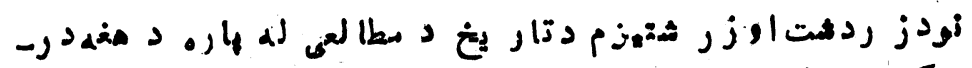

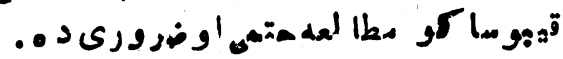

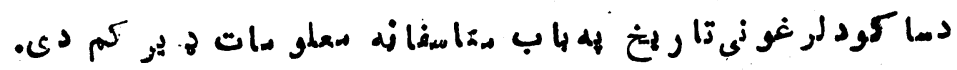

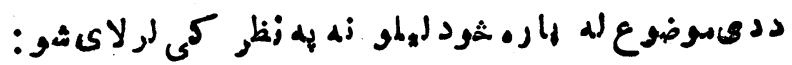

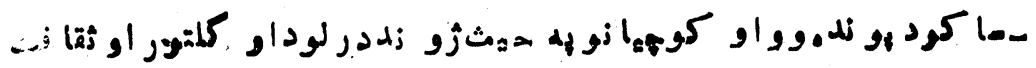

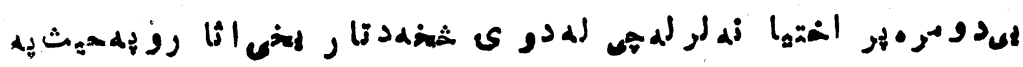

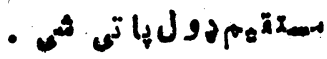


- rr -

$\ldots 0^{5}$ liand glap jlimjlijl

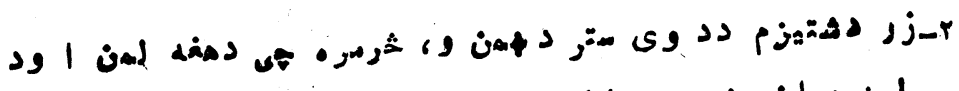

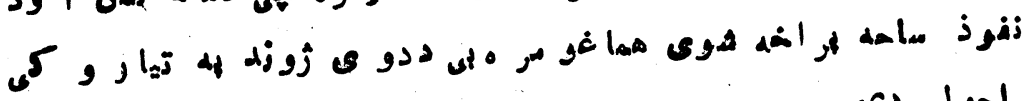

ا اهو Jैى

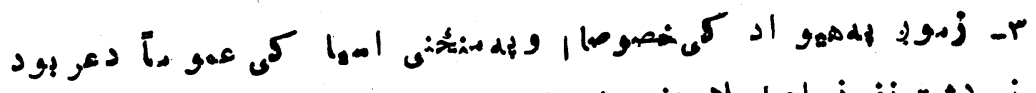

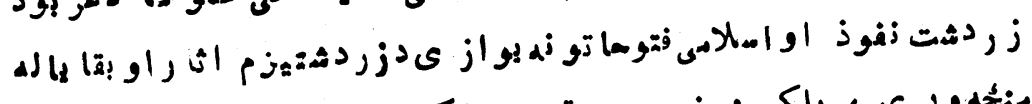

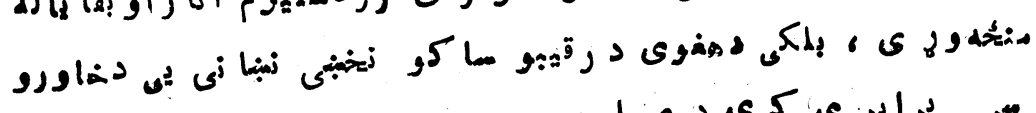

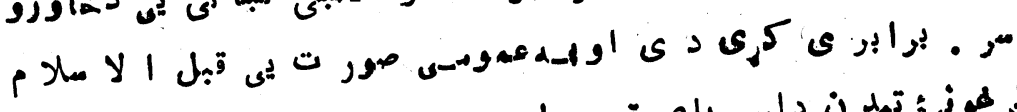

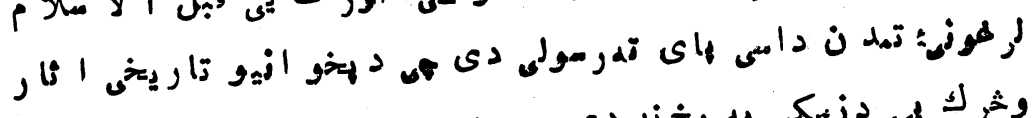

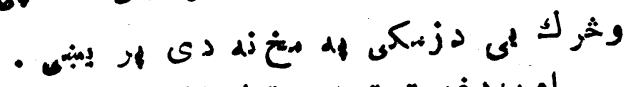

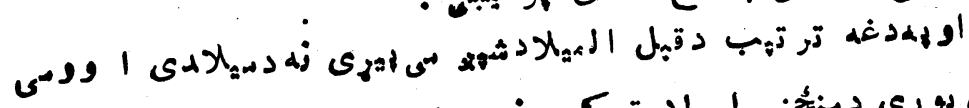

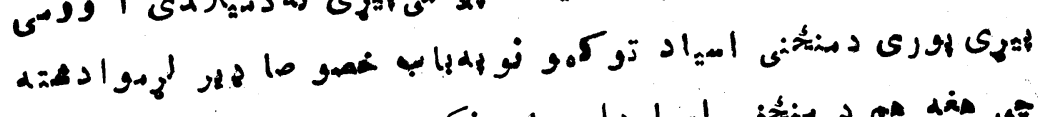

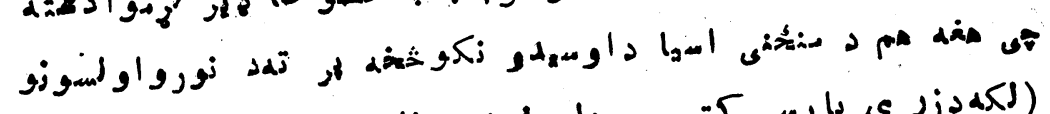

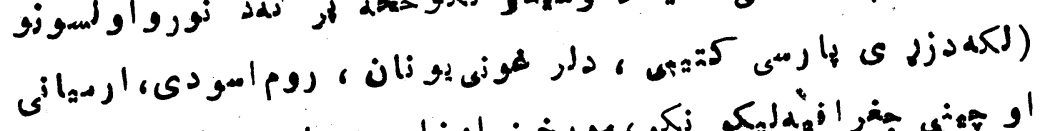

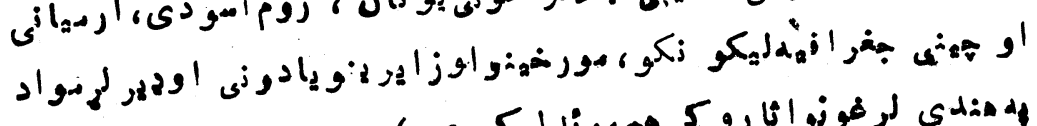

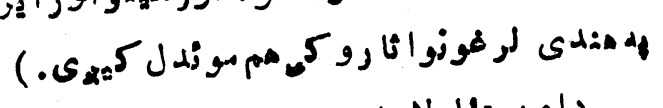

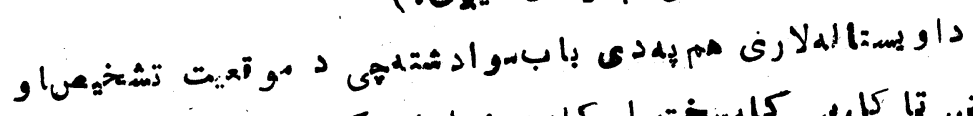

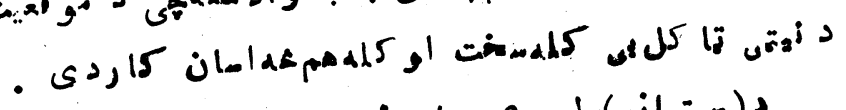
د)

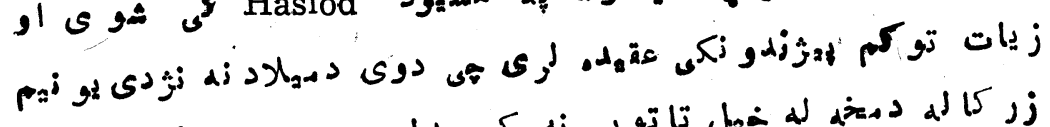

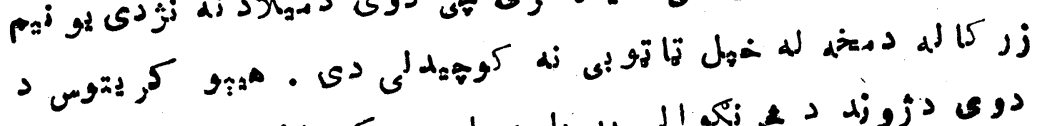

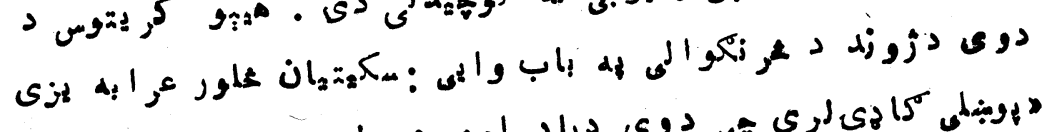

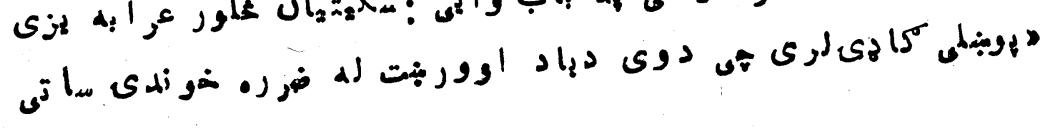


د....

- Mro

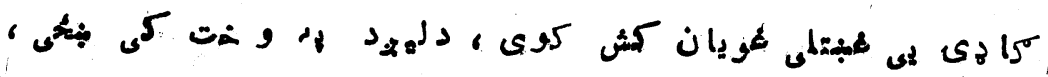

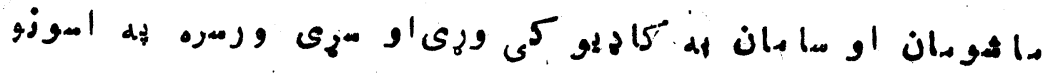

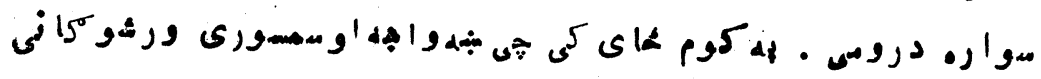

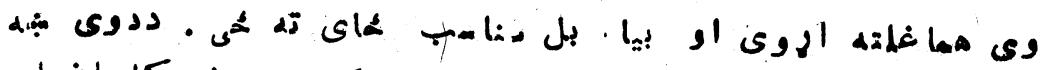

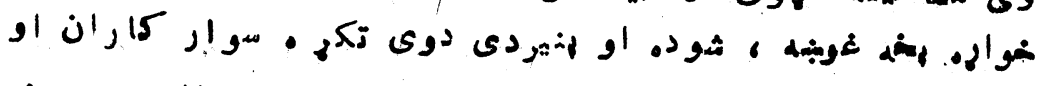

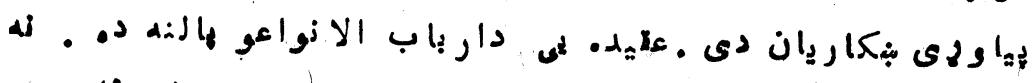

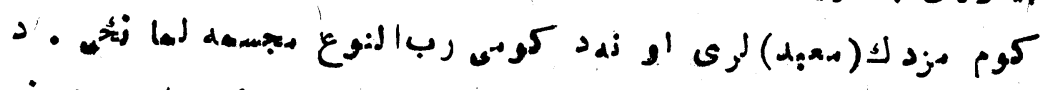

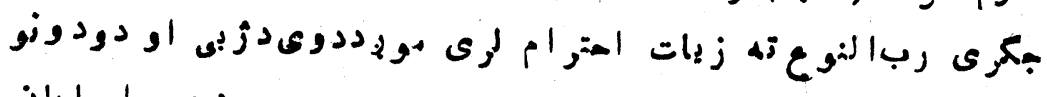

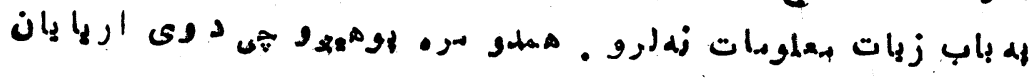

- (1) v

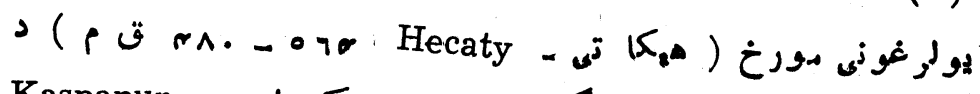

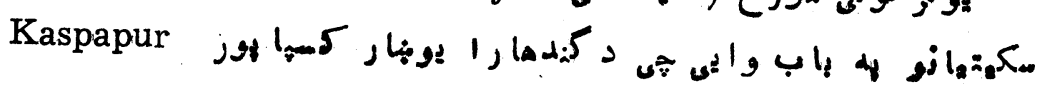

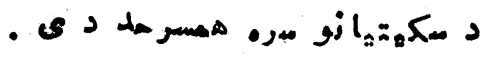

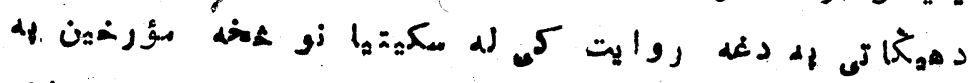

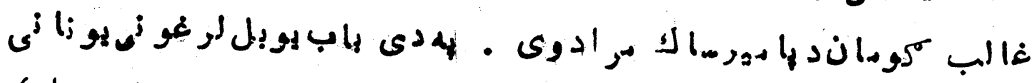

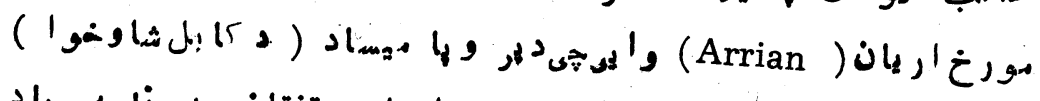

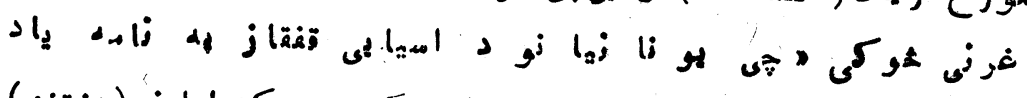

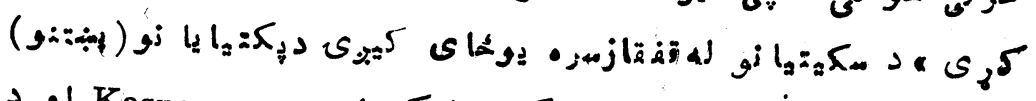

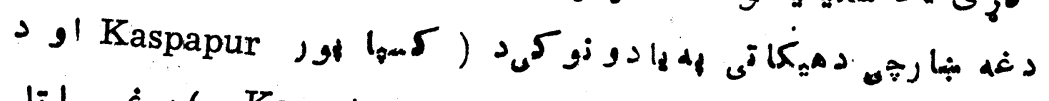

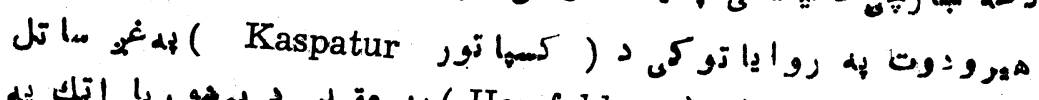

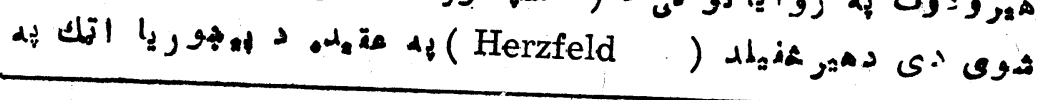

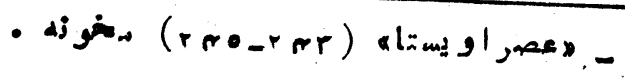




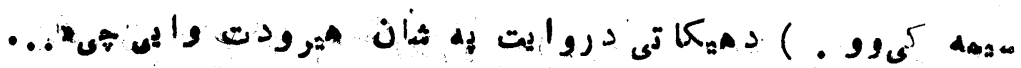

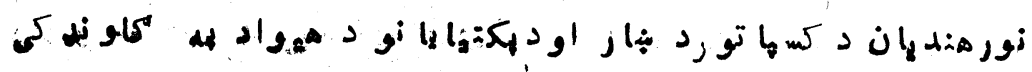

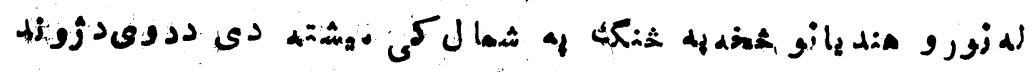

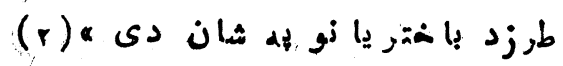

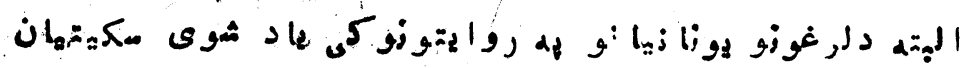

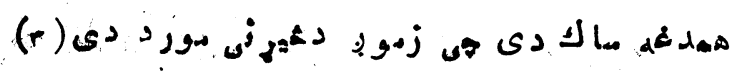

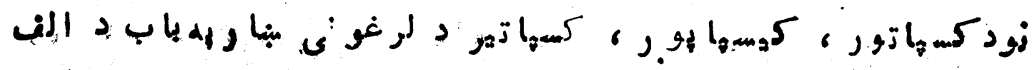

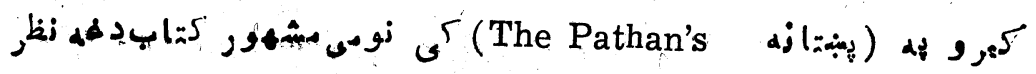

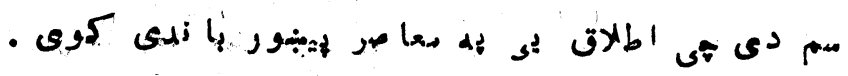

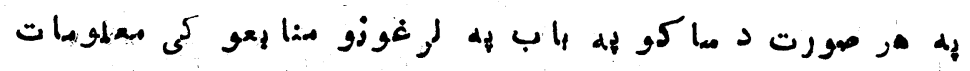

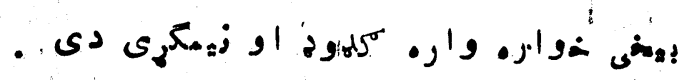

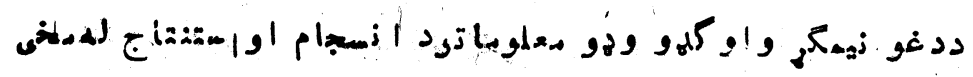

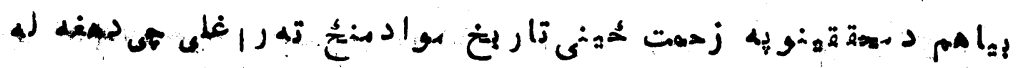

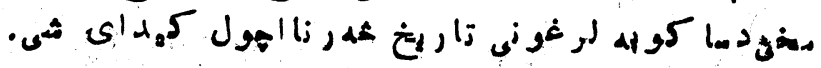

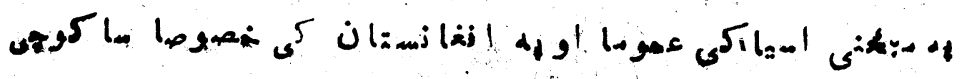

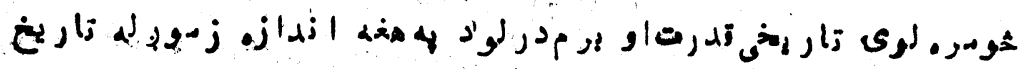

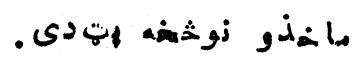

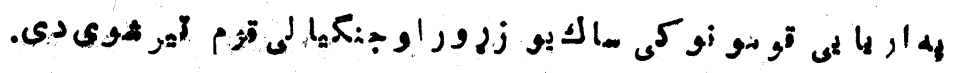

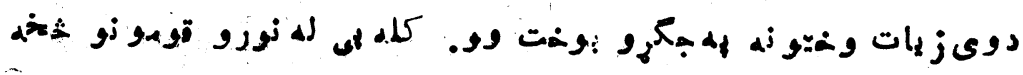

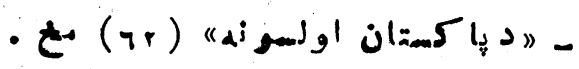

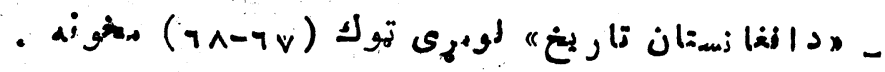


د ما كو ...

-

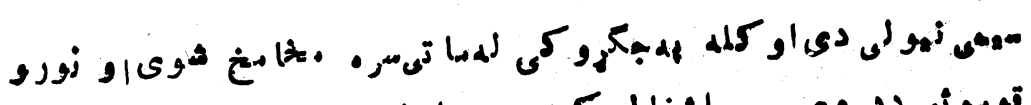

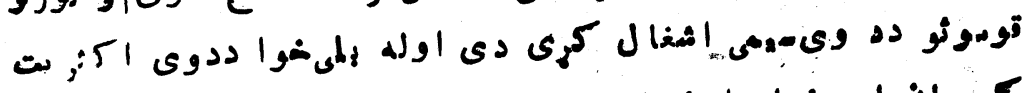

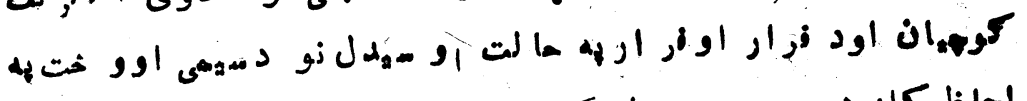

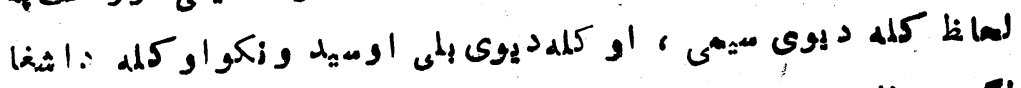

- المر

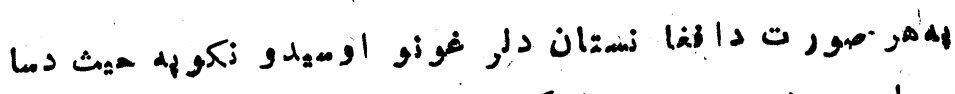

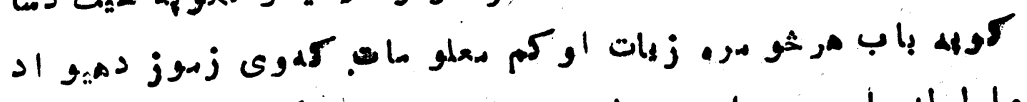

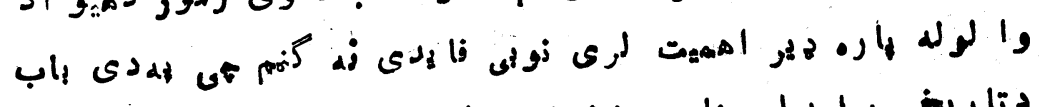

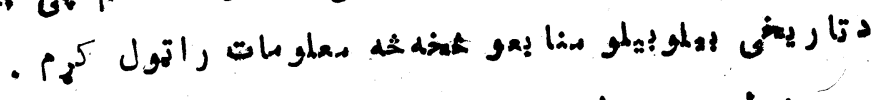

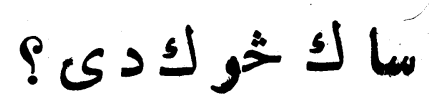

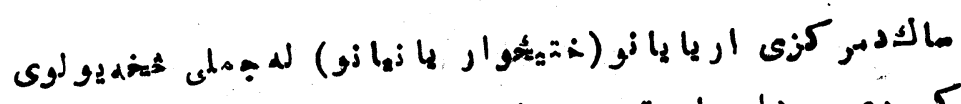

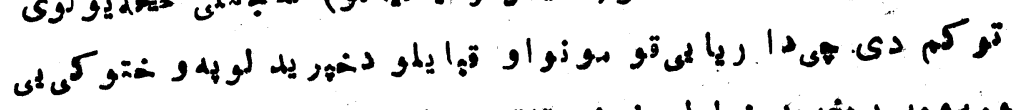

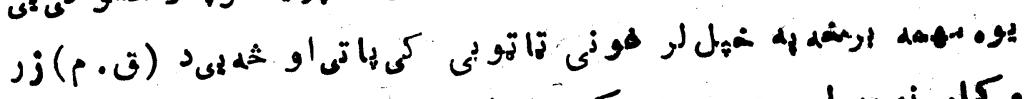

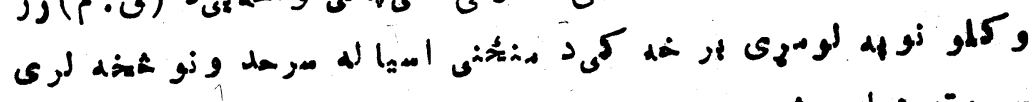

.

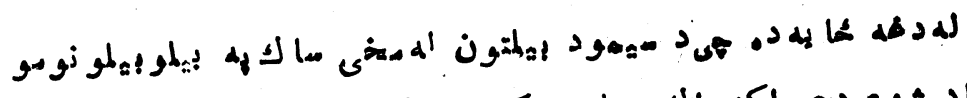

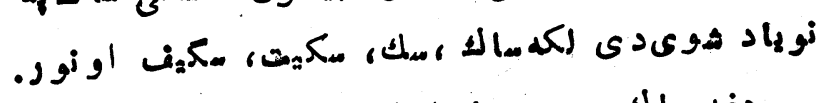

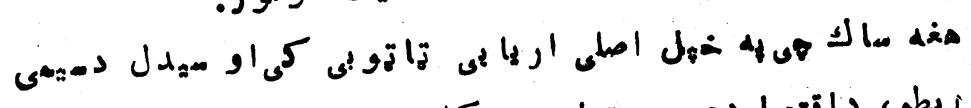

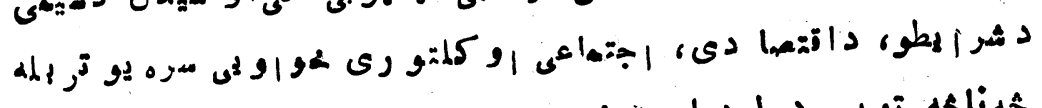

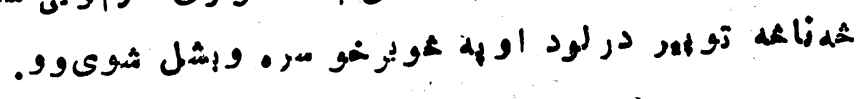


rvo

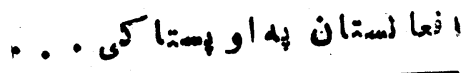

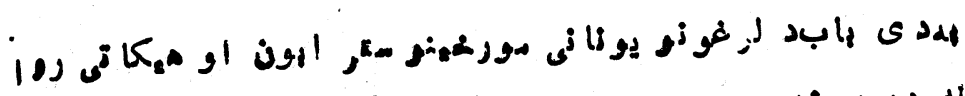

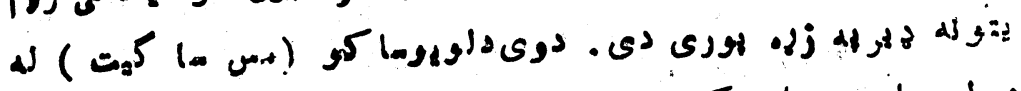
:

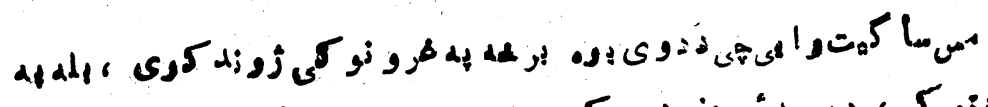

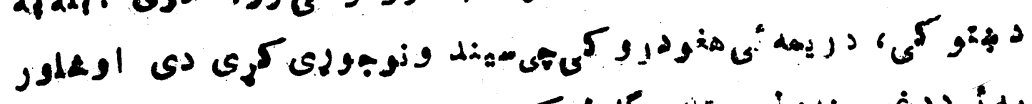

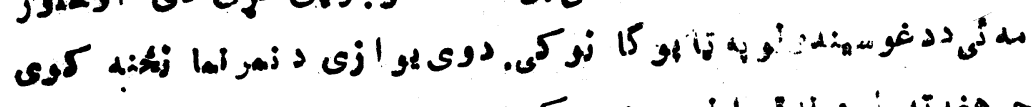

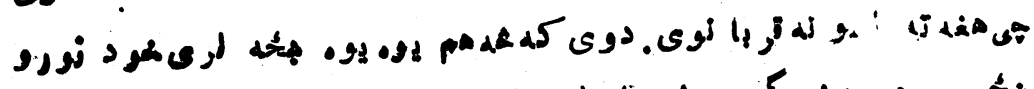

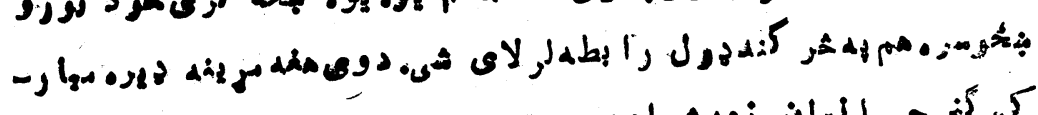

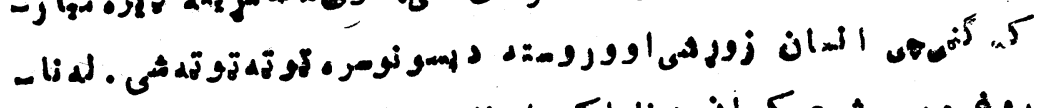

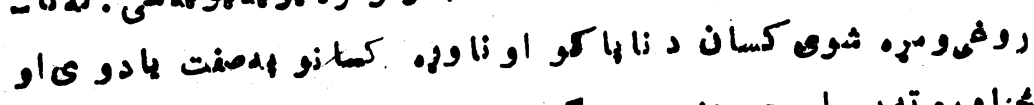

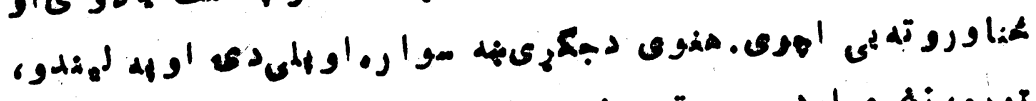

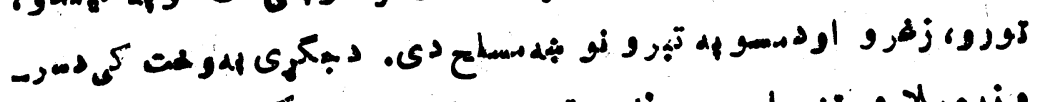

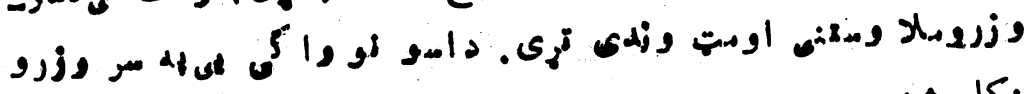

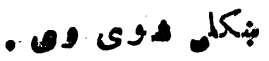

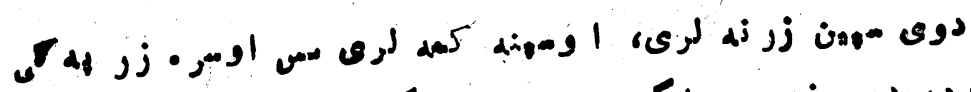

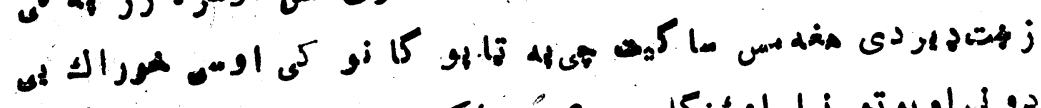

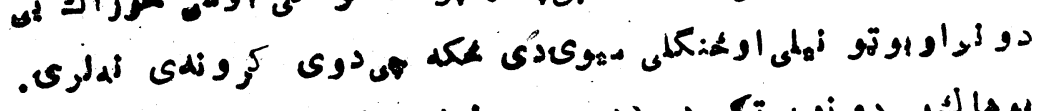

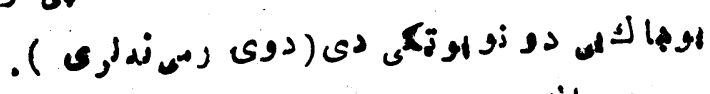

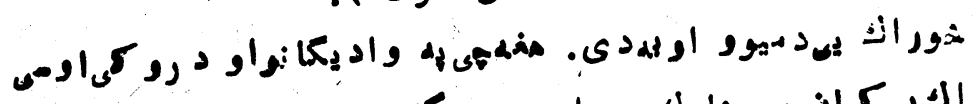

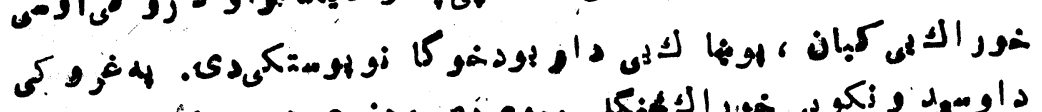

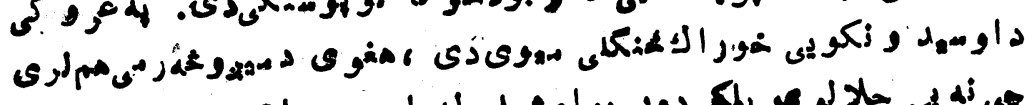

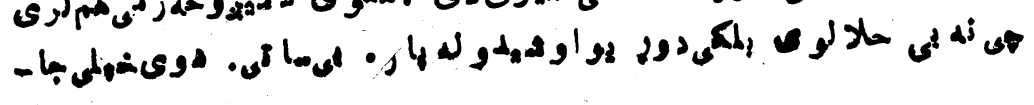




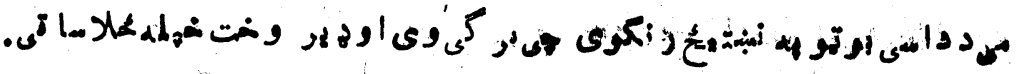

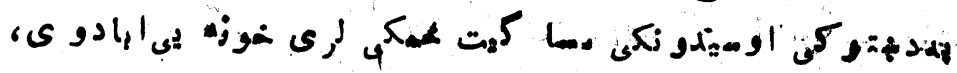

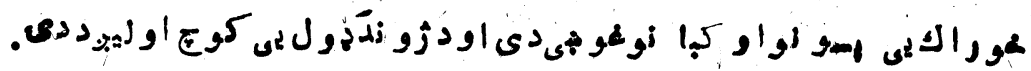

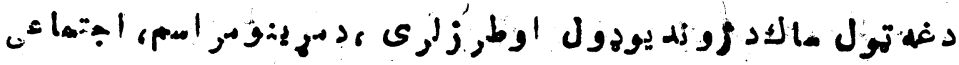

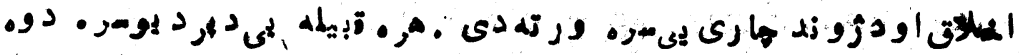

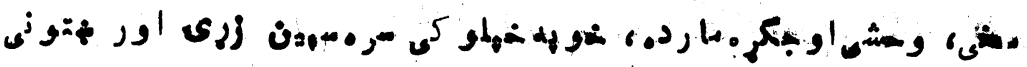
(1) (1)

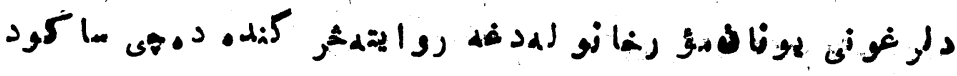

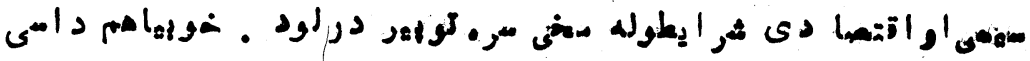

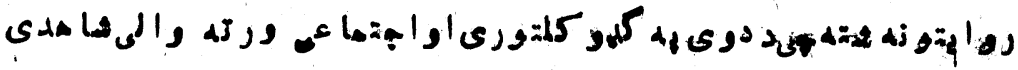

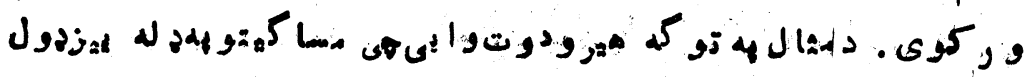

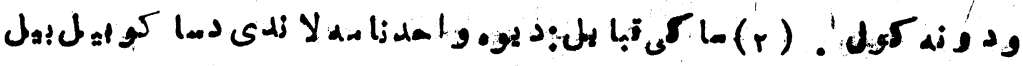

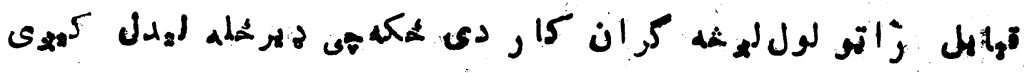

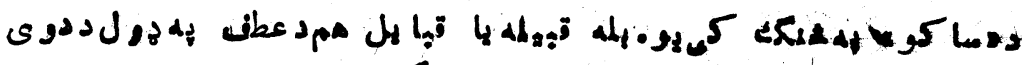

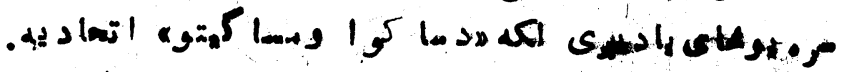

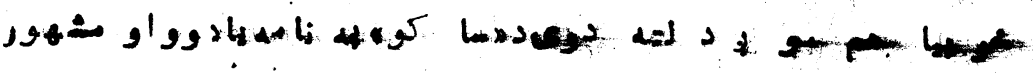

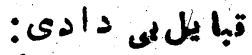

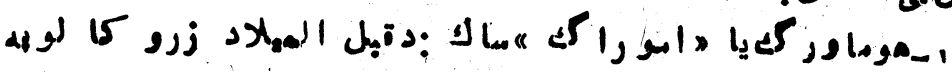

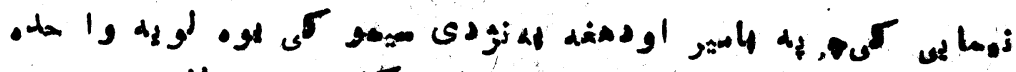

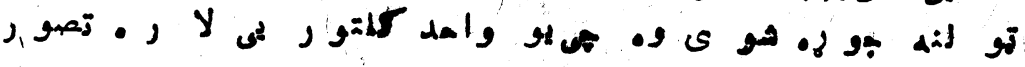

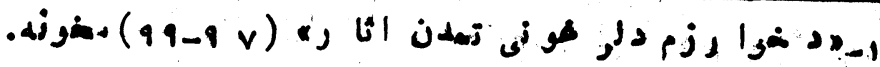

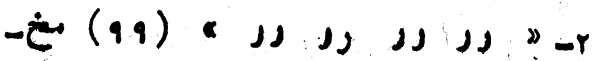


-

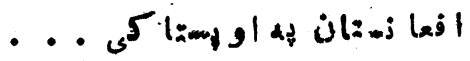

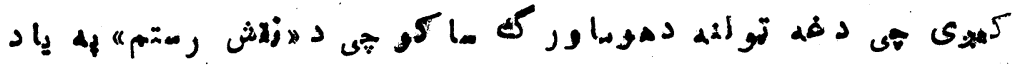

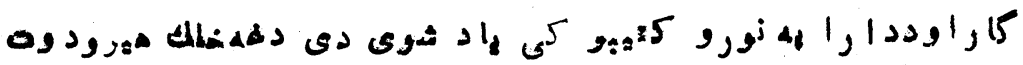

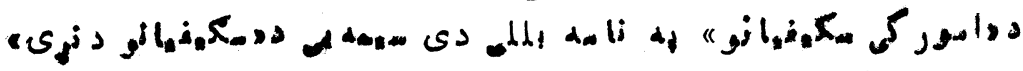

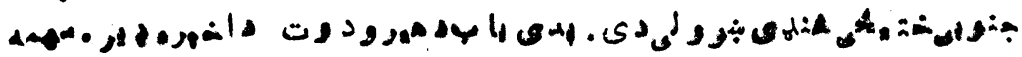

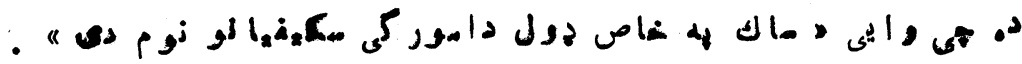

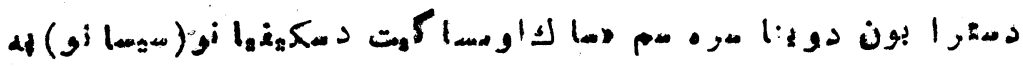

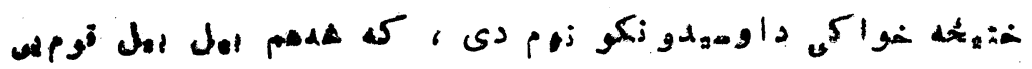

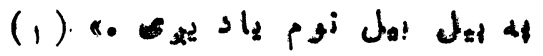

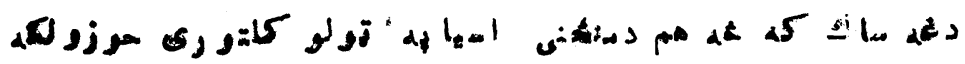

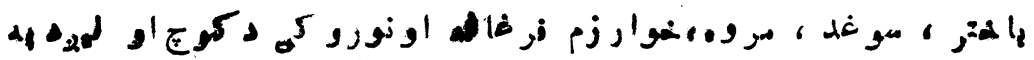

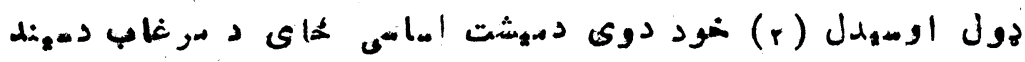

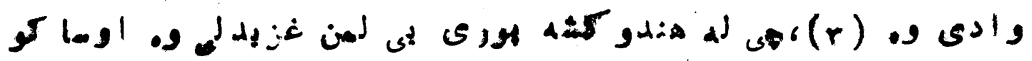

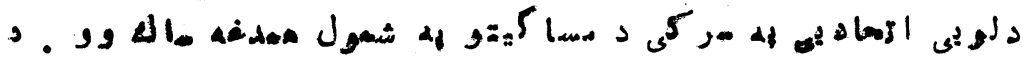

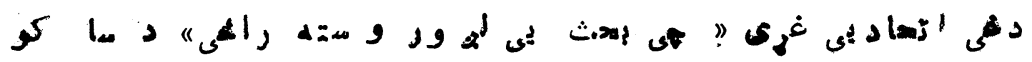

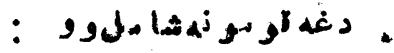

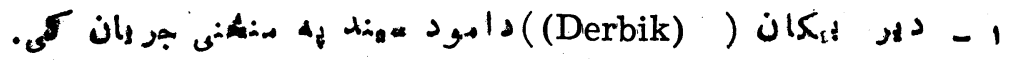

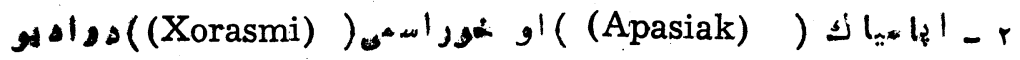
ا

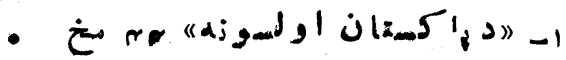

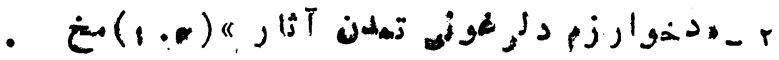
- r

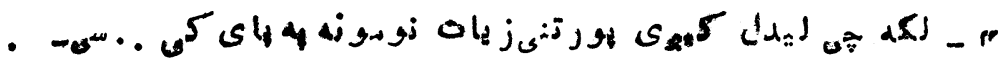

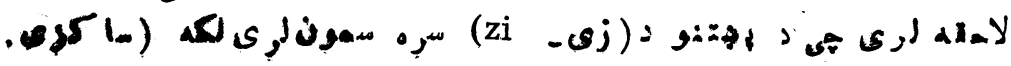
(... 
...

$-r \cdot-$

"

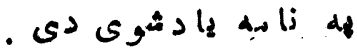

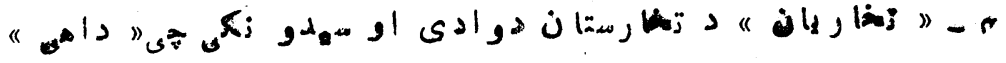

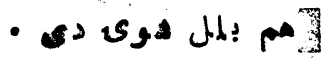

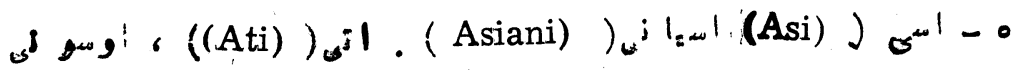

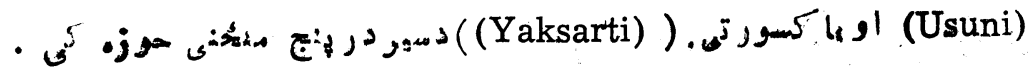

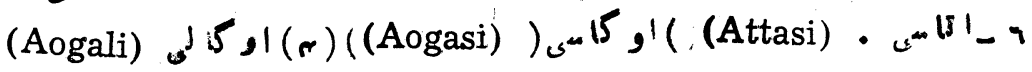

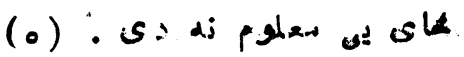

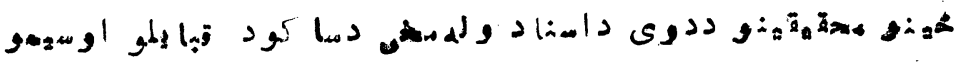

:

- ((Saka-tigro-Xaada) )

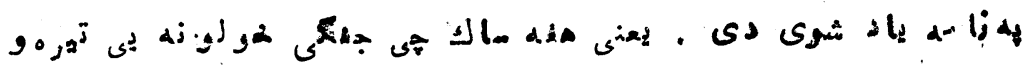

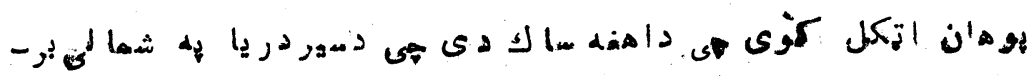

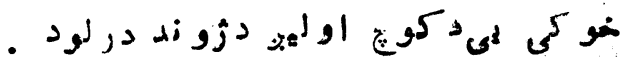

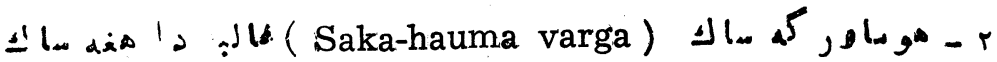

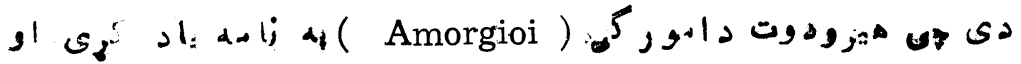

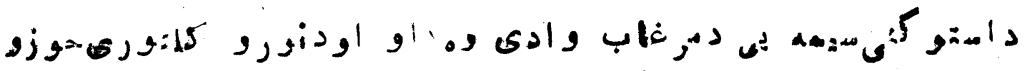

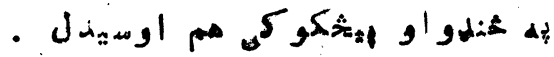

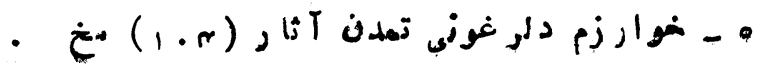


$-1-$

- . Flimglas jlimilaí

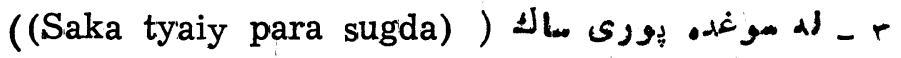

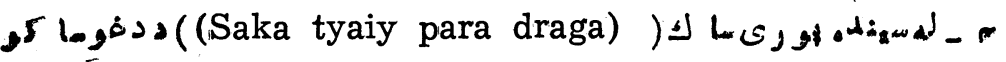

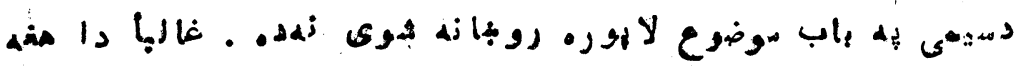

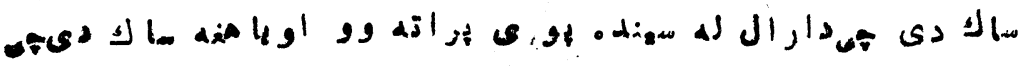

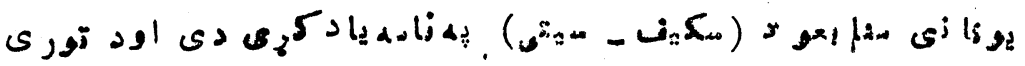

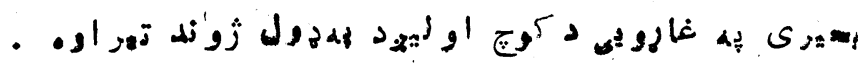

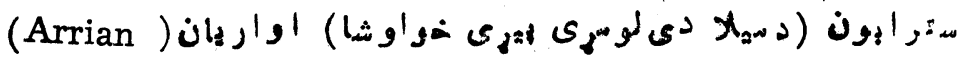

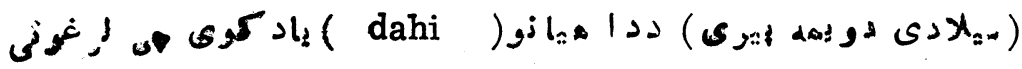

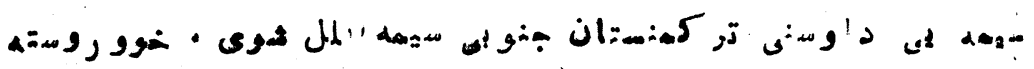
. و و

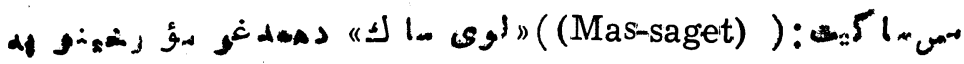

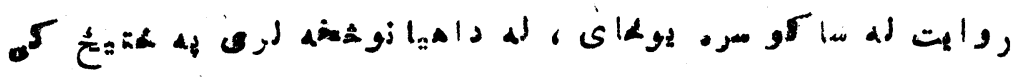

2.

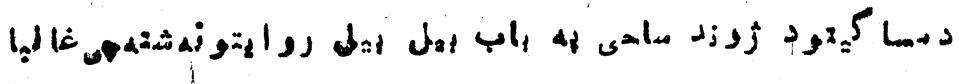

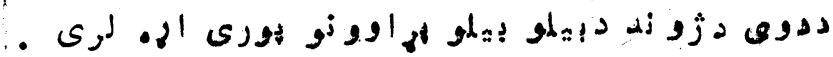

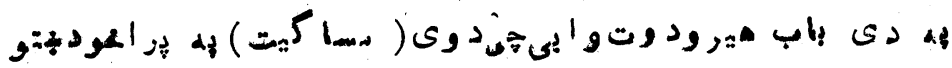

-

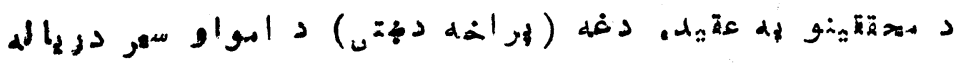

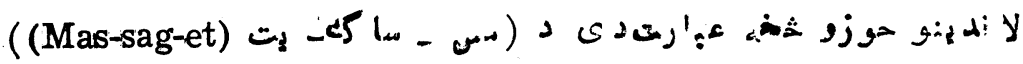

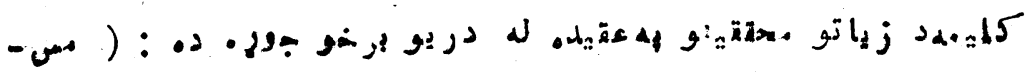

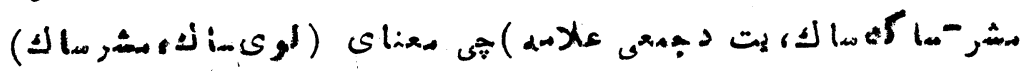

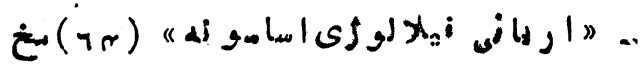


-.

-mr

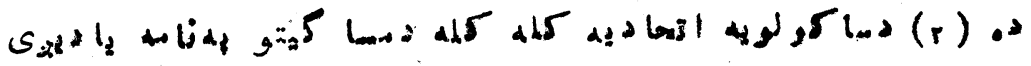

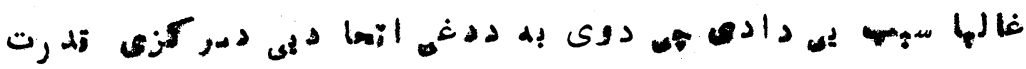

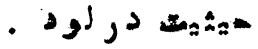

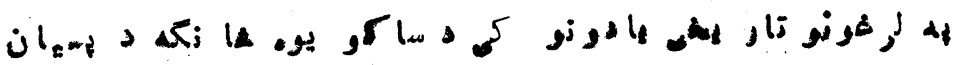

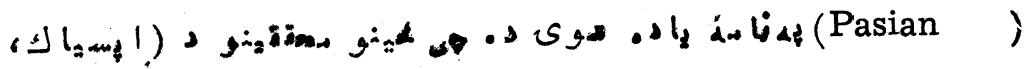

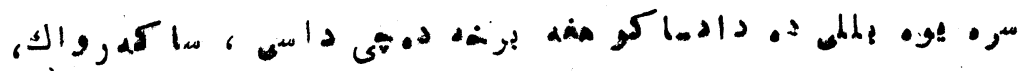

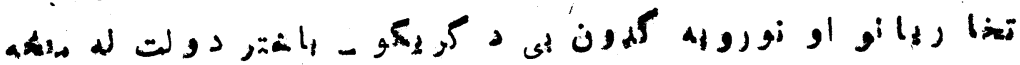

- 29

د)

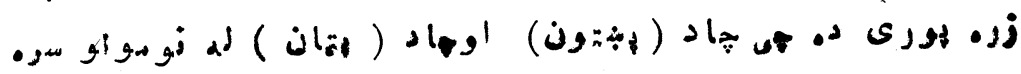

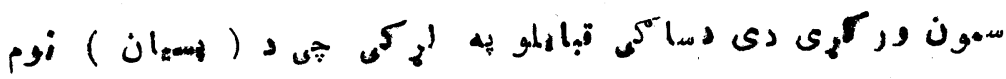

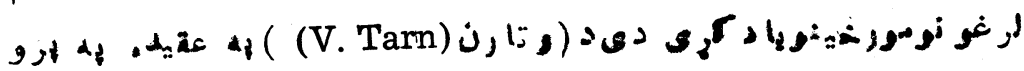

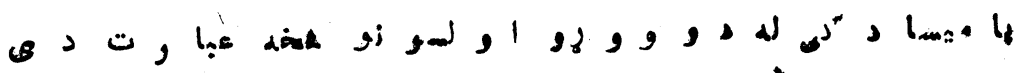

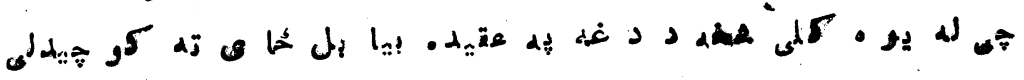
وو • (H. W. Baley) (

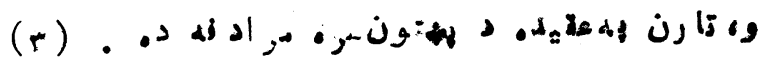

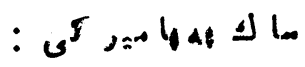

(

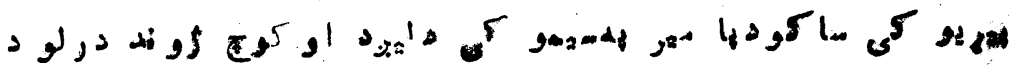

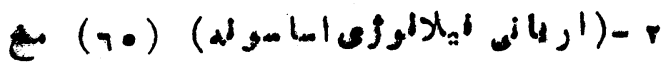

$$
\begin{aligned}
& \text { (Irr) }
\end{aligned}
$$


$-m+$

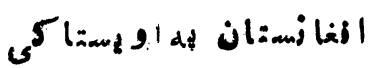

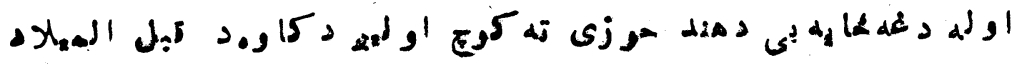
دارو كار أو

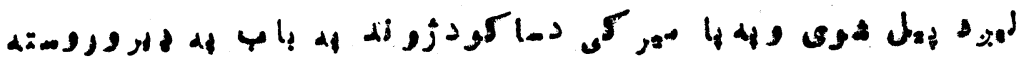

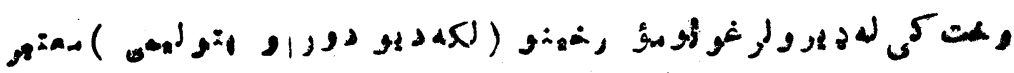

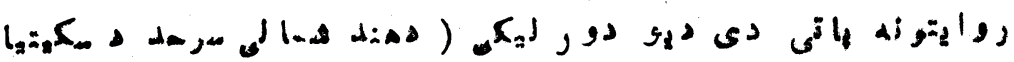

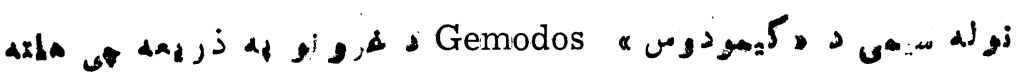

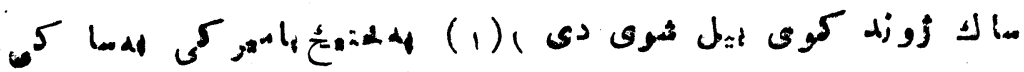

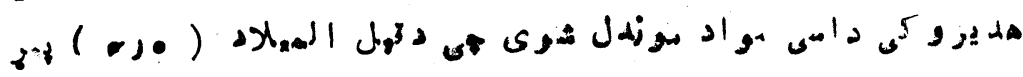

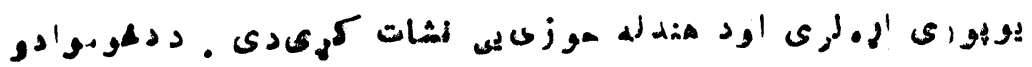

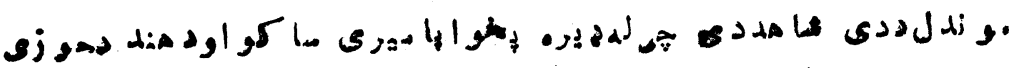

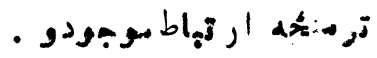

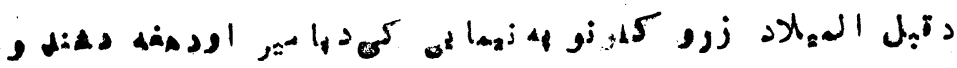

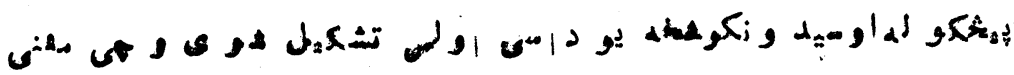

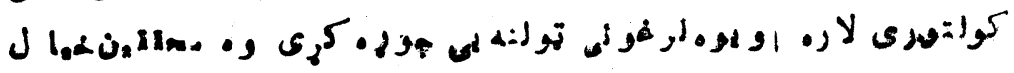

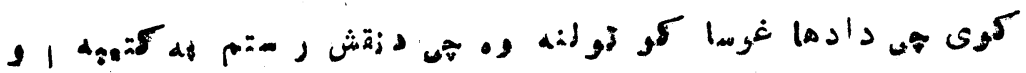

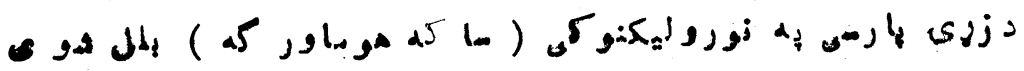

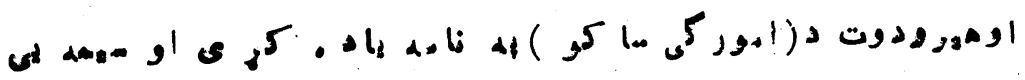

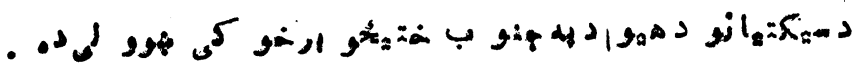

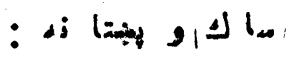

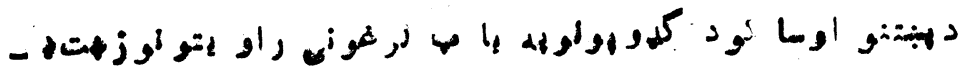

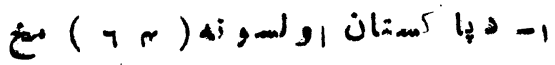




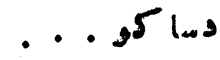

$-m+$

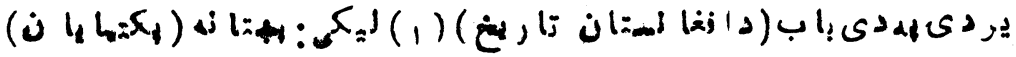

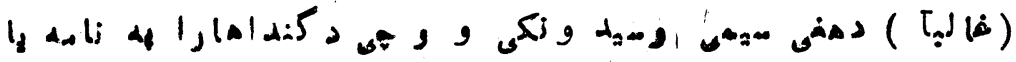

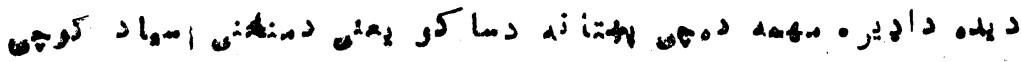

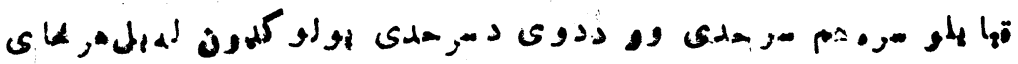
定

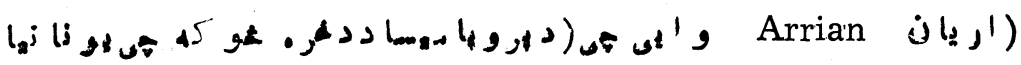

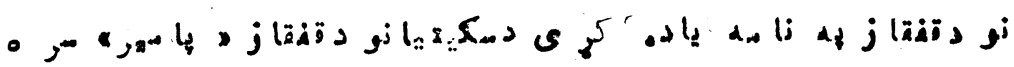

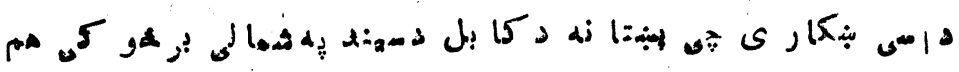

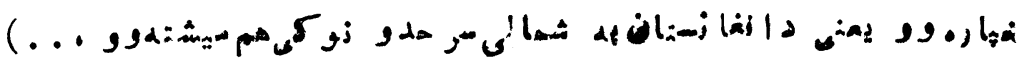

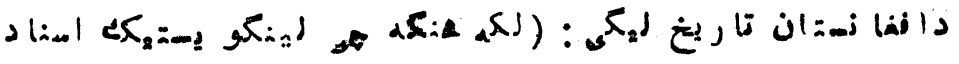

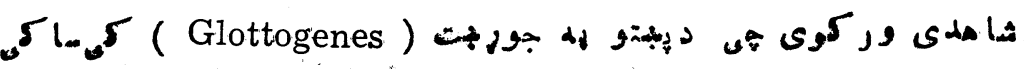

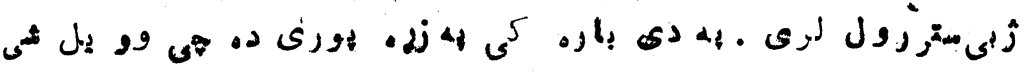

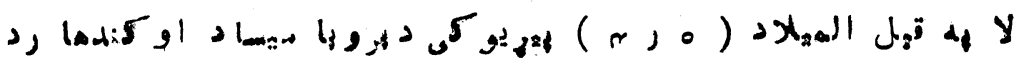

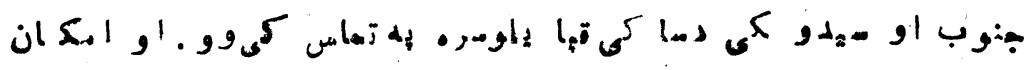

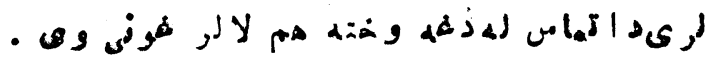

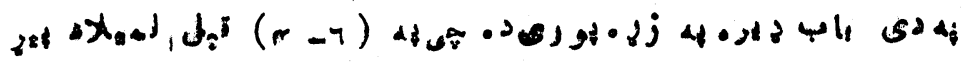

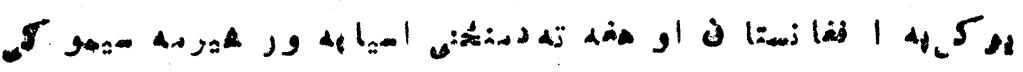

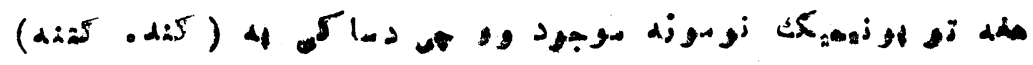

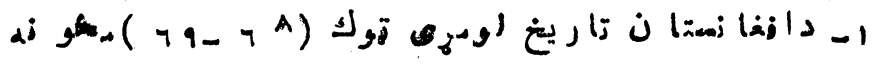


$m \cdot m$

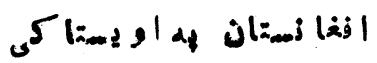

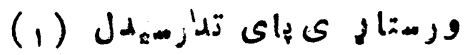

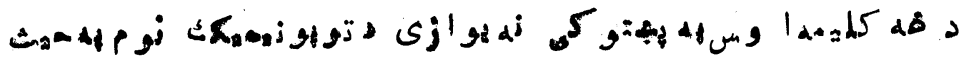

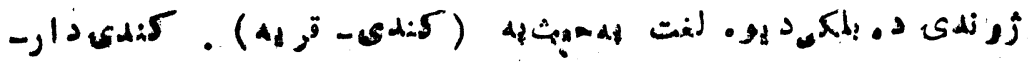

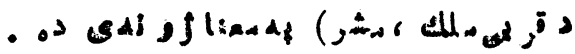

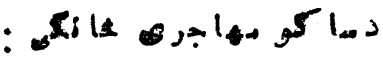

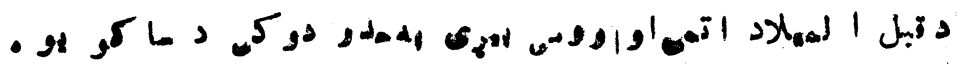

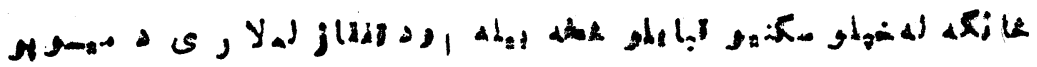

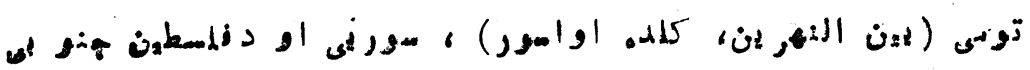

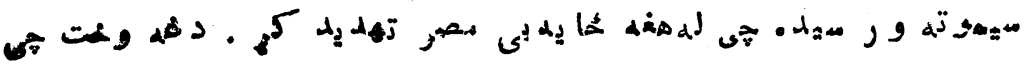

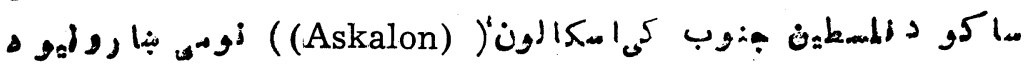

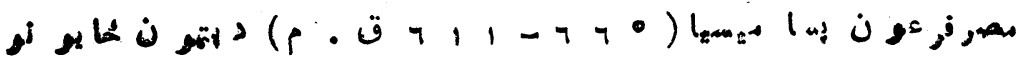

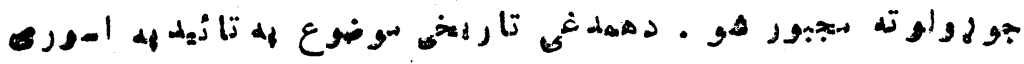

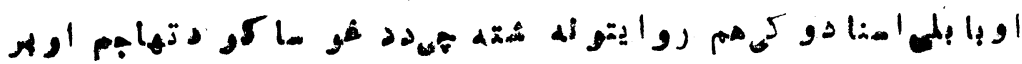
(r) . (r)

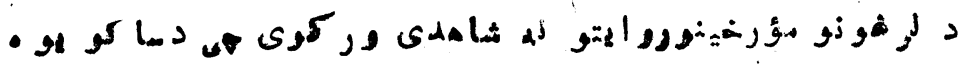

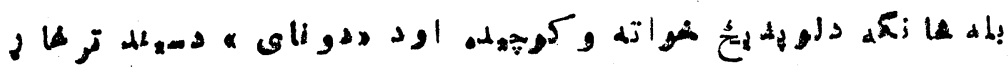

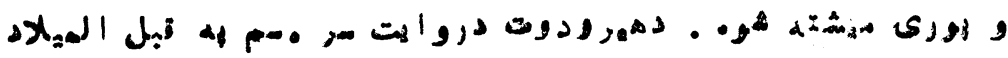

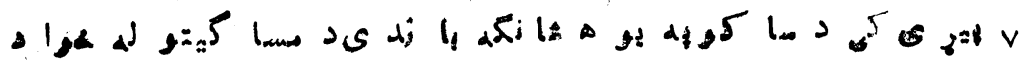

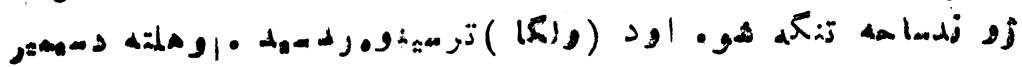

-

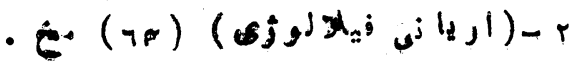




$$
\text { ... S r las }
$$

$-67-$

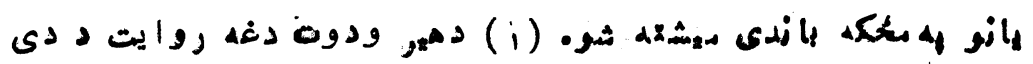

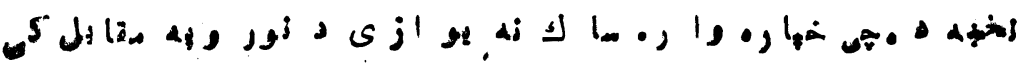

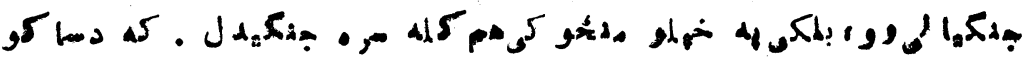

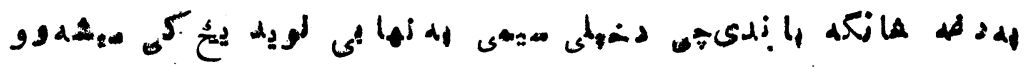

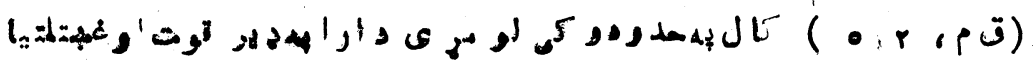

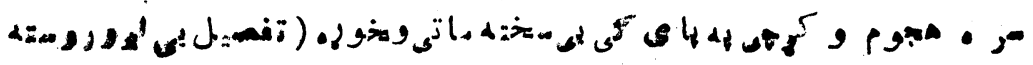

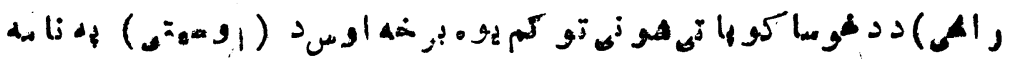

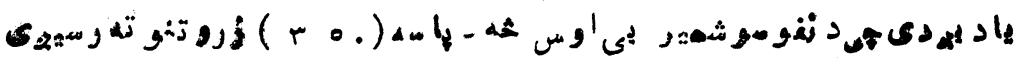

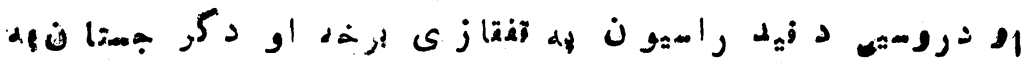

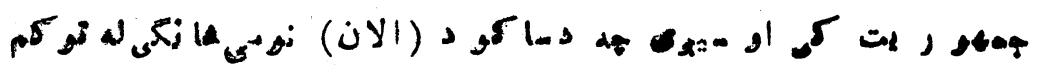

(r) . v s dine

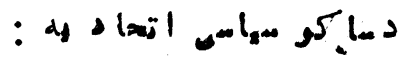

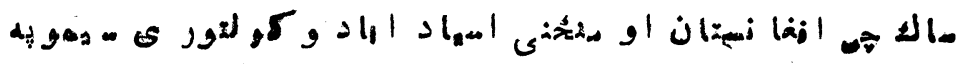

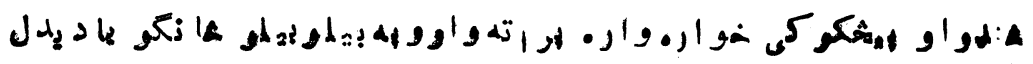

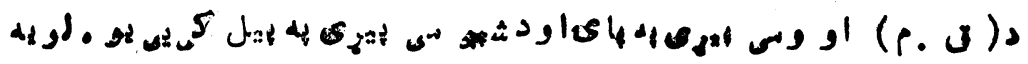

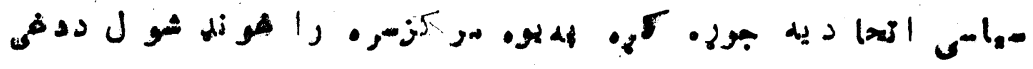

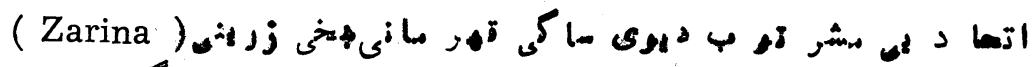

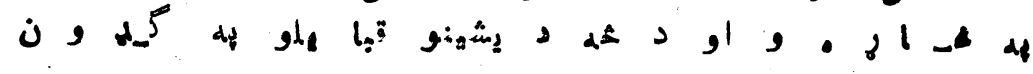

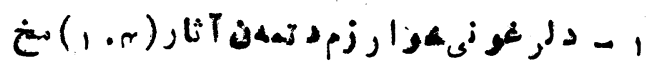

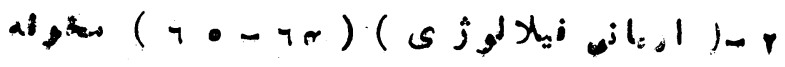


$-e^{2}-$

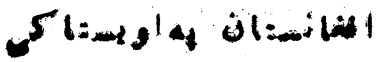

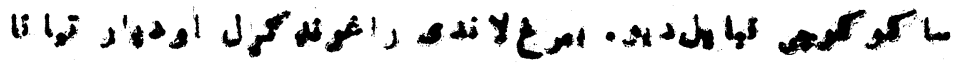

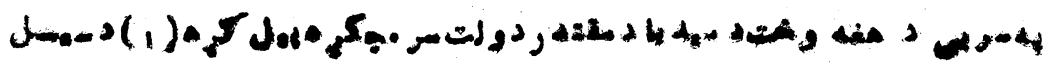

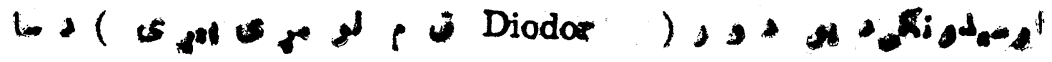

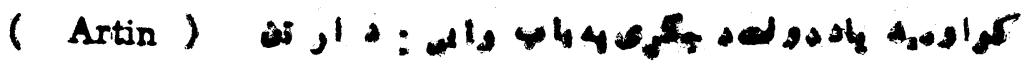
ه

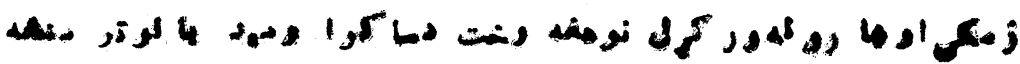

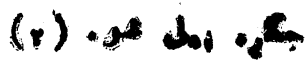

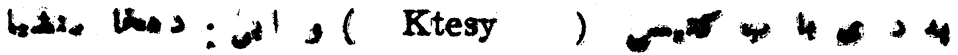
زو له

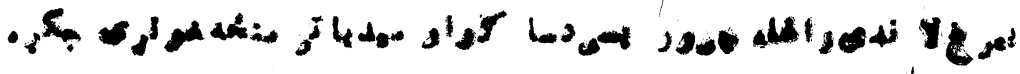

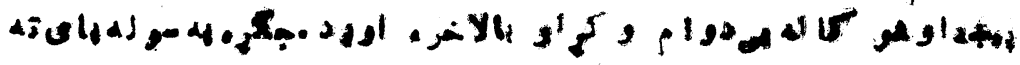

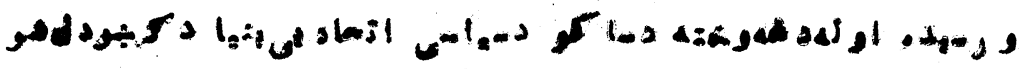

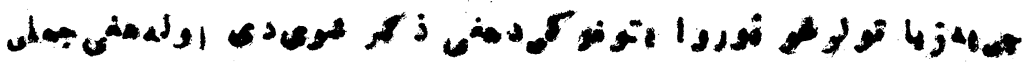

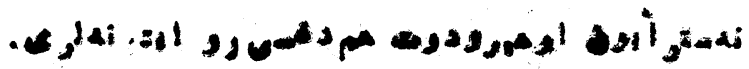

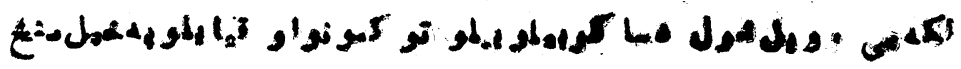

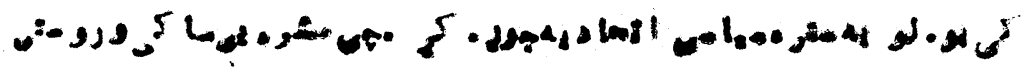

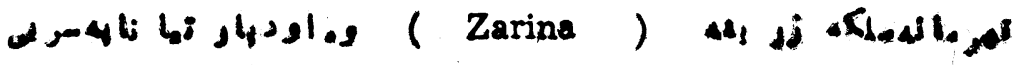
-

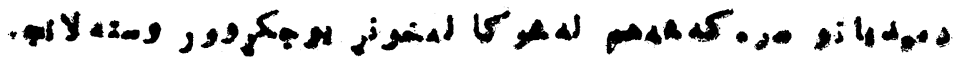

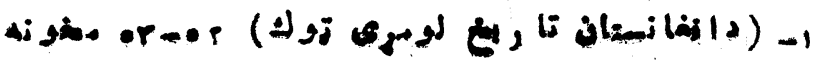

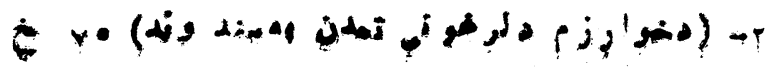


-.. 5102

mA-

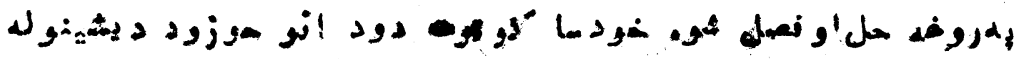

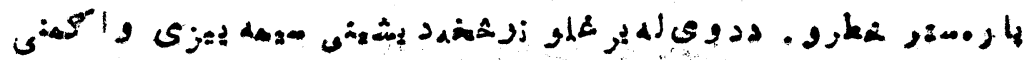

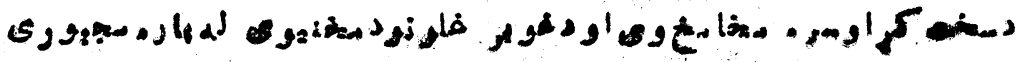

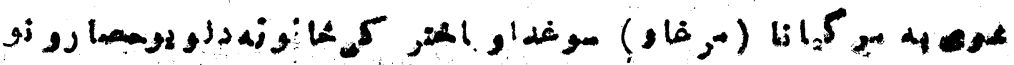

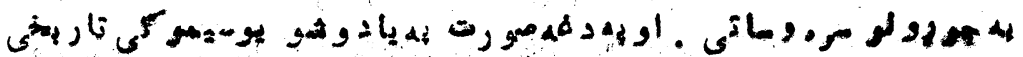
1). $6 y^{4} 4290015$ at

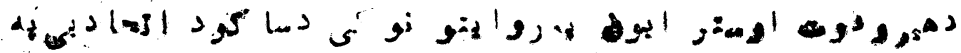

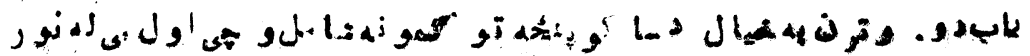

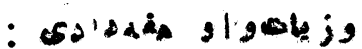

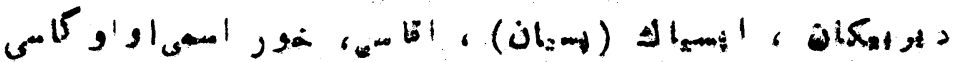

$$
\text { (r) } \cdot(\sqrt{3} 15,1)
$$

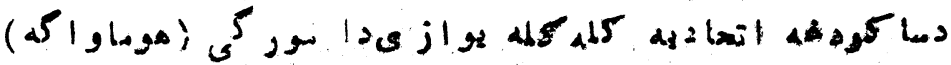

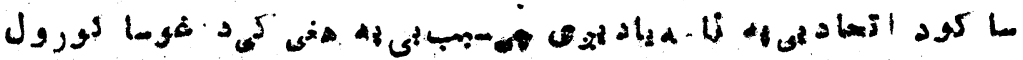

أهمتد

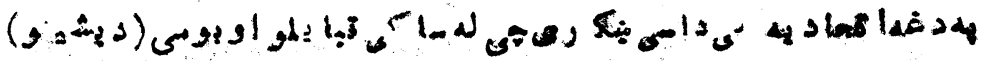
مح

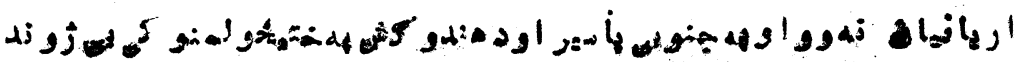

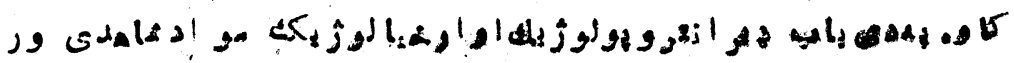

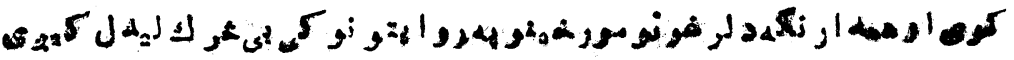

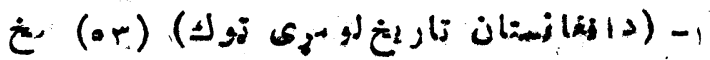

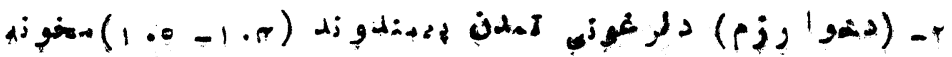


$\rightarrow 1-$

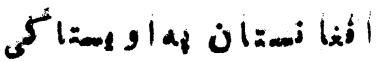

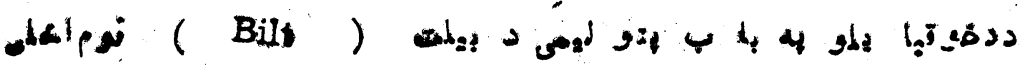

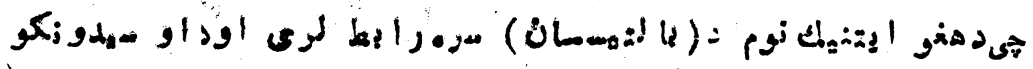

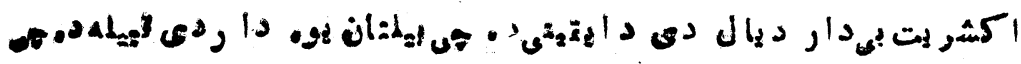

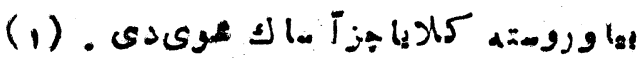
همدار زكله الهد

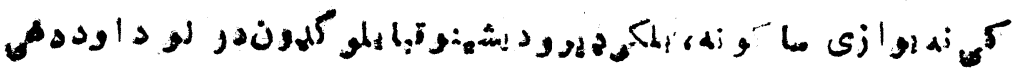

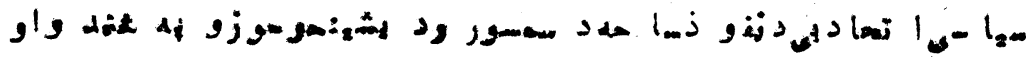

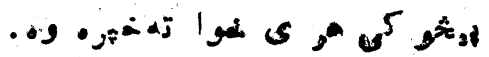

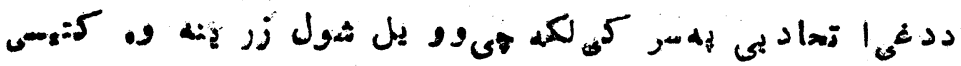

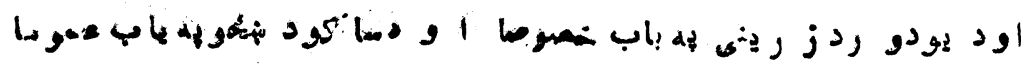

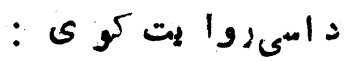

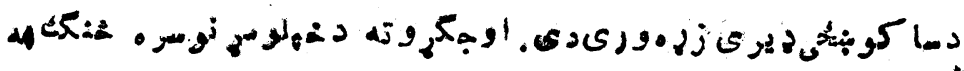

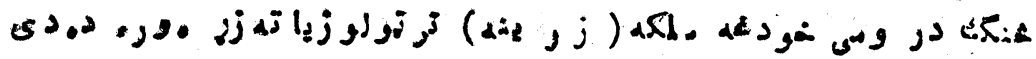

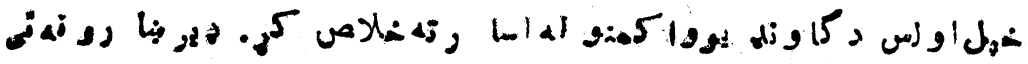

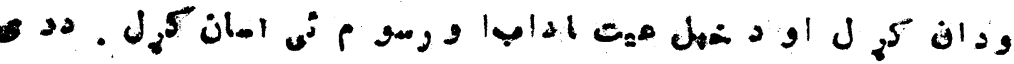

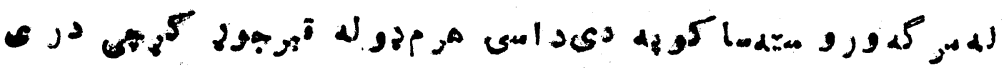

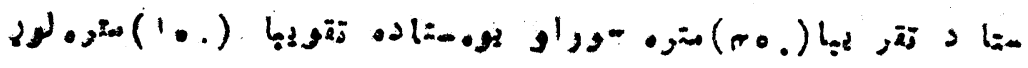

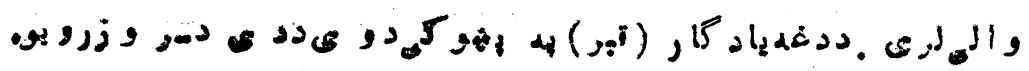

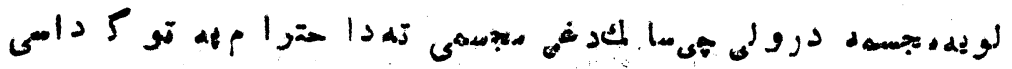
- 


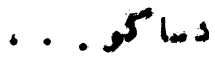

$\rightarrow$

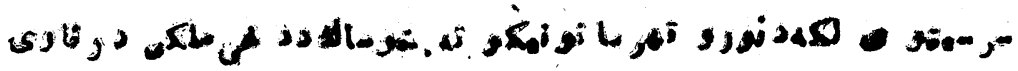

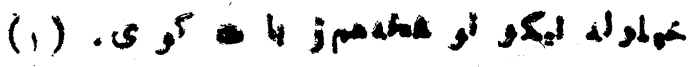
:

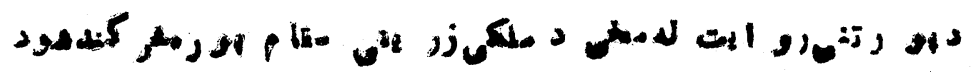

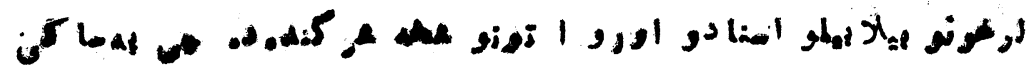

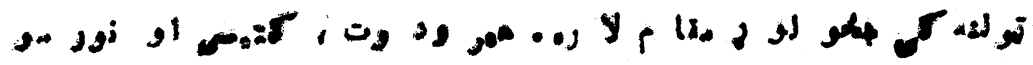

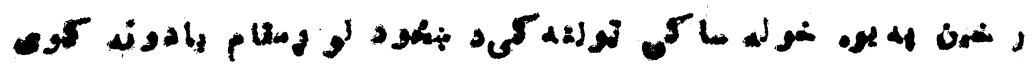

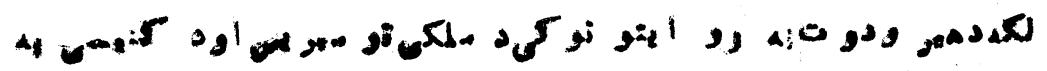

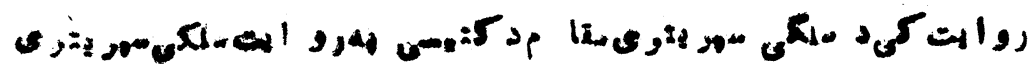

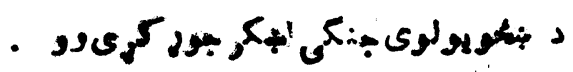

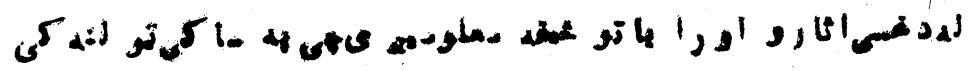

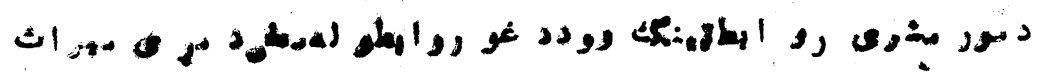

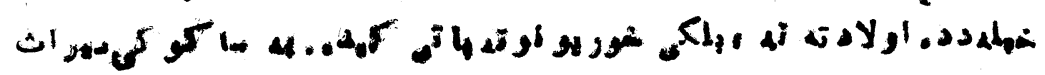

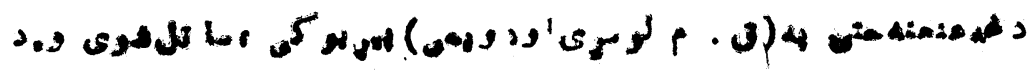

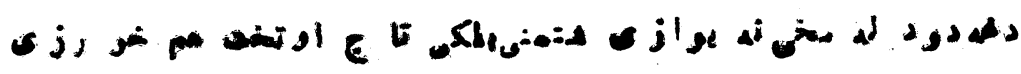

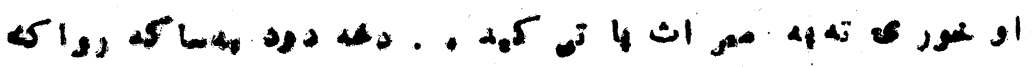

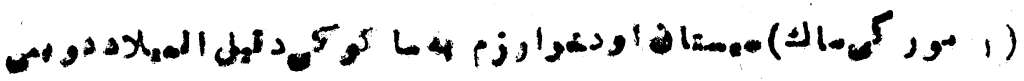
$(1) \cdot$, V

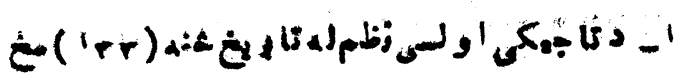

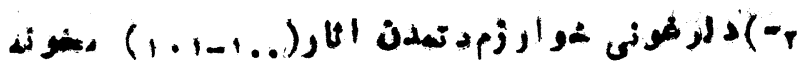




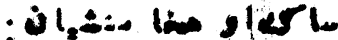

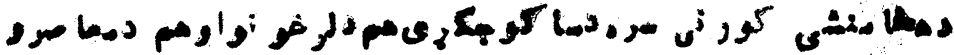

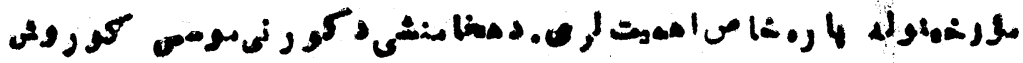

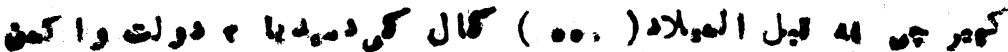

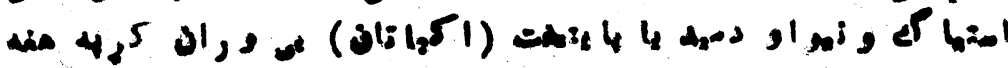
3.

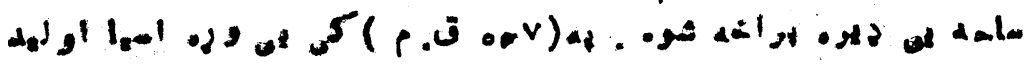

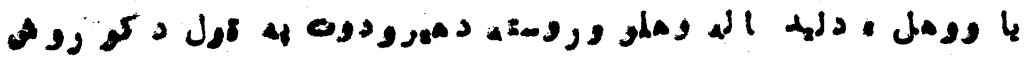

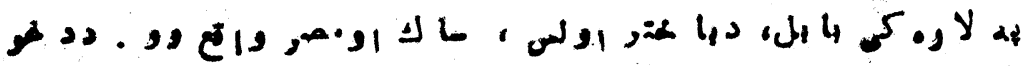

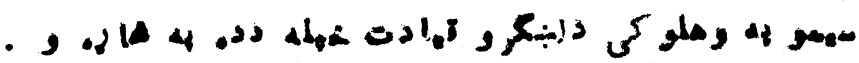

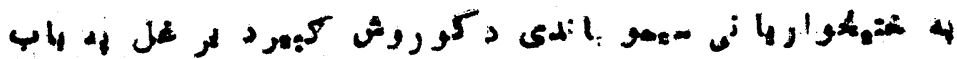

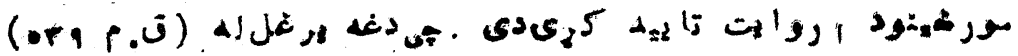

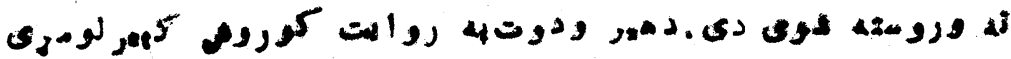

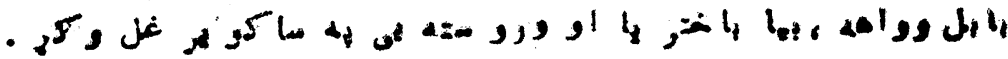

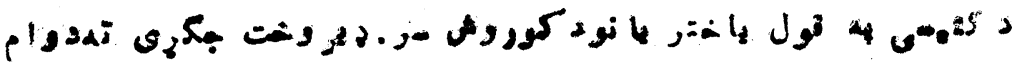

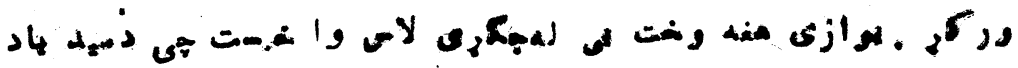

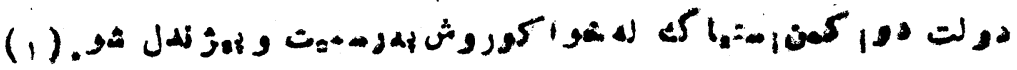

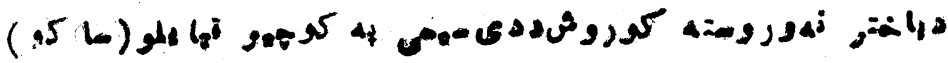
و

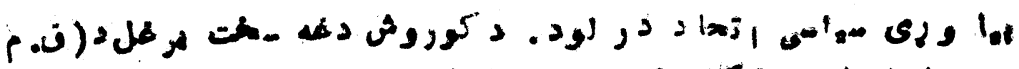

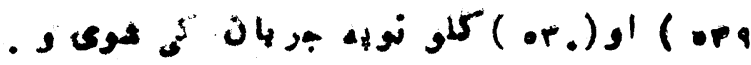

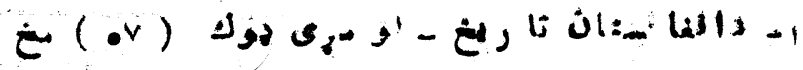




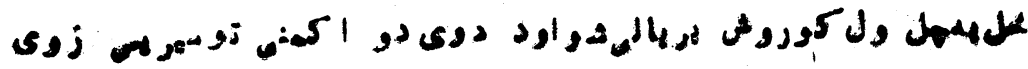

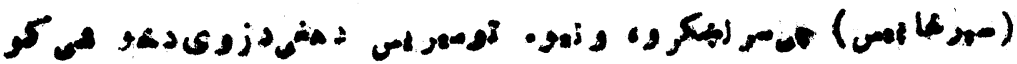

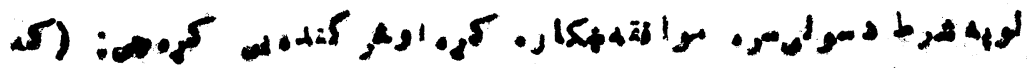

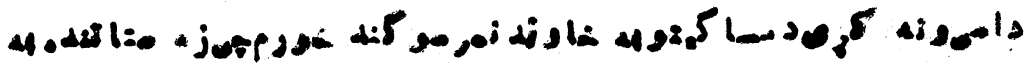

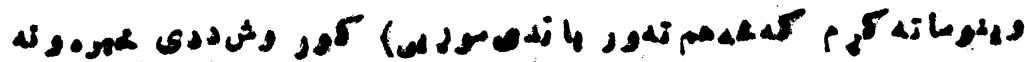

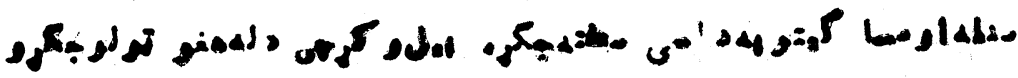


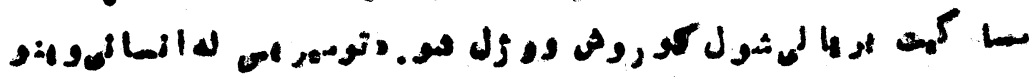

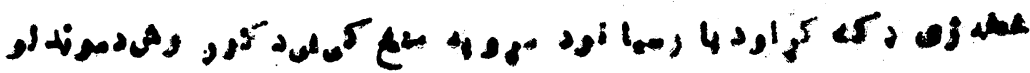

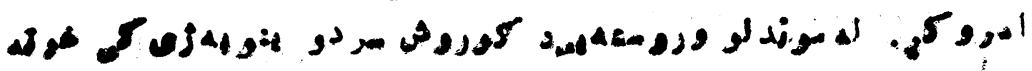
كواو

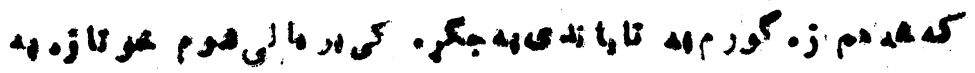

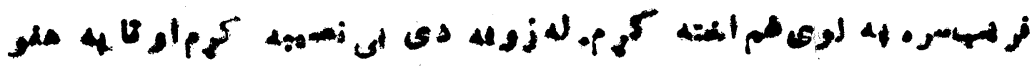
(1)

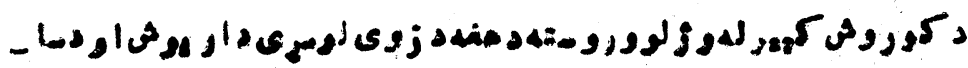

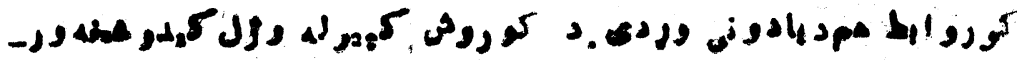

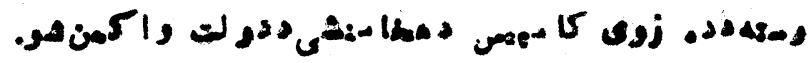

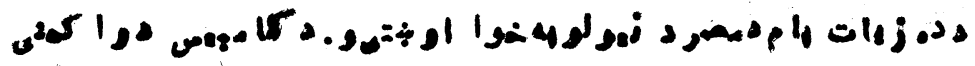

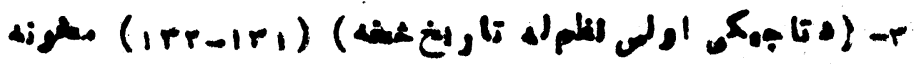

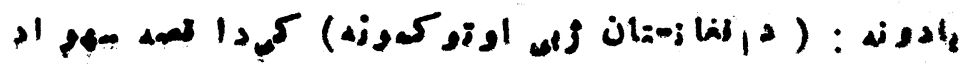

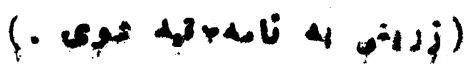


ك:="

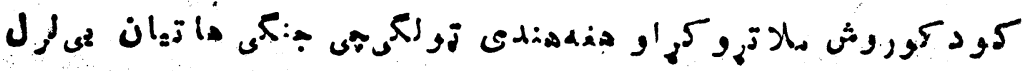

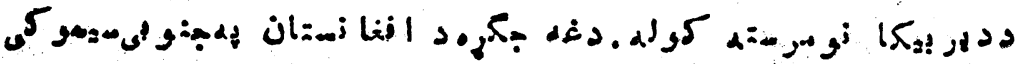

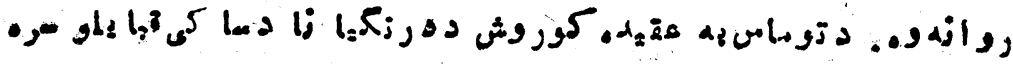

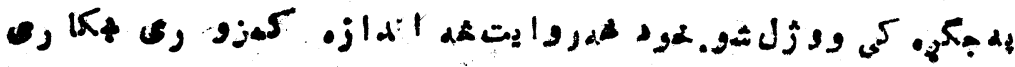

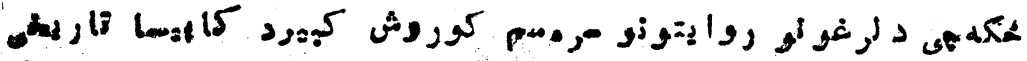

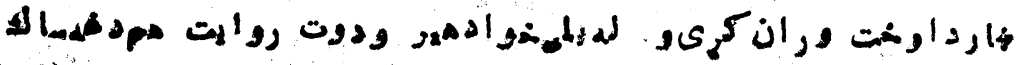

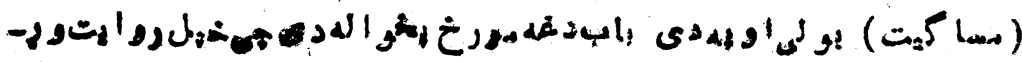

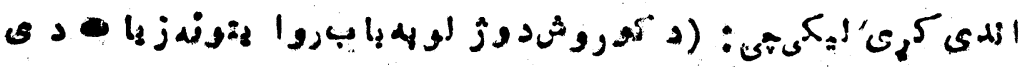

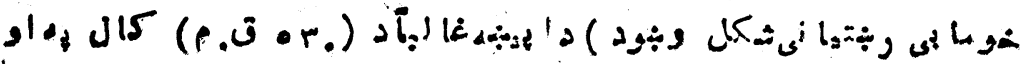

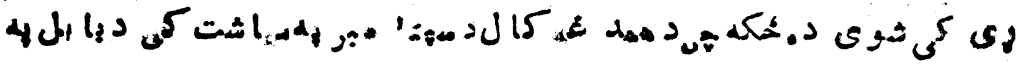

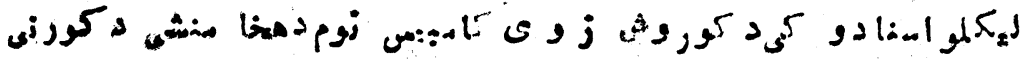

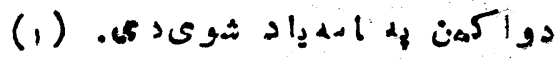
.

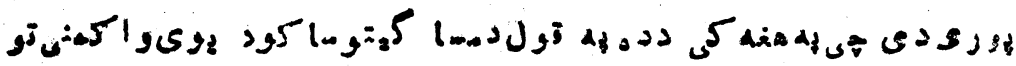

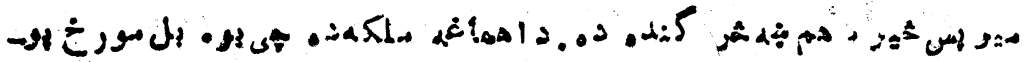

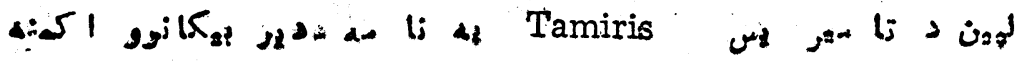

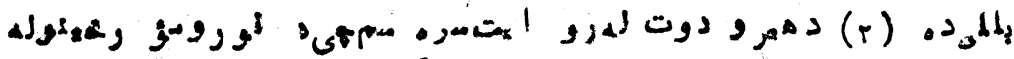

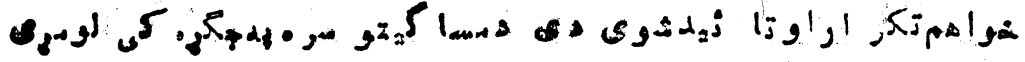

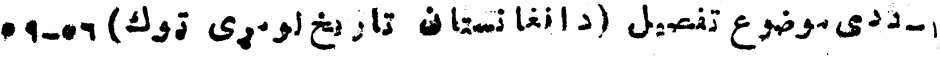

di dis

- 


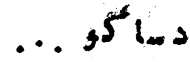

$-6+$

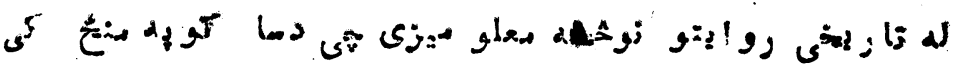

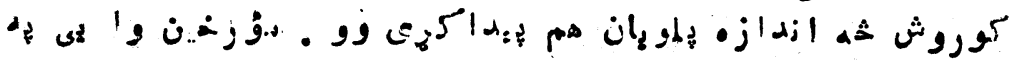

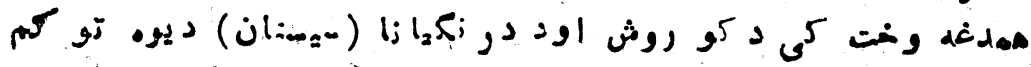

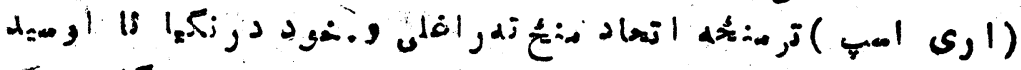

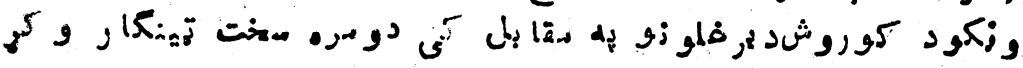

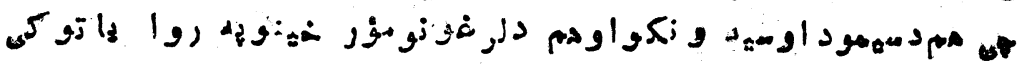

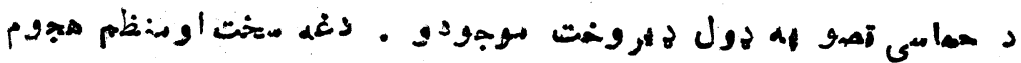

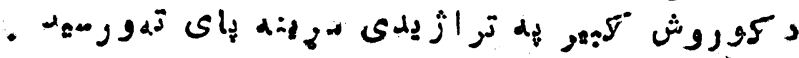

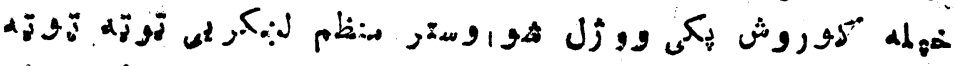

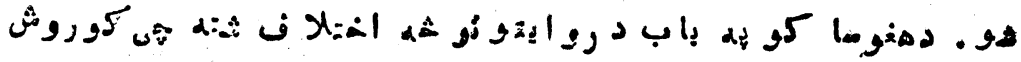

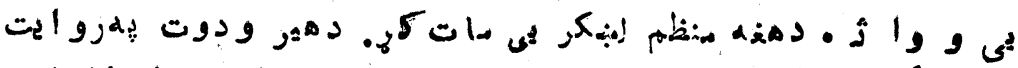

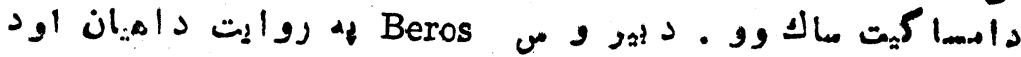

•

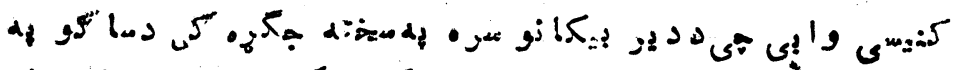

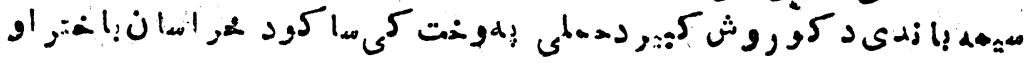

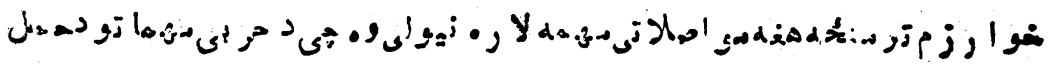

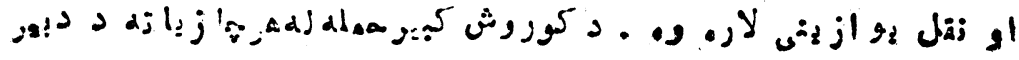

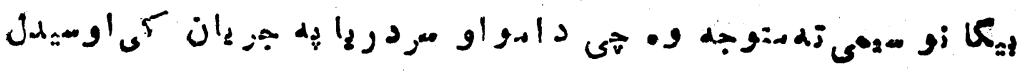

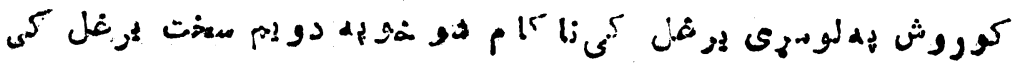

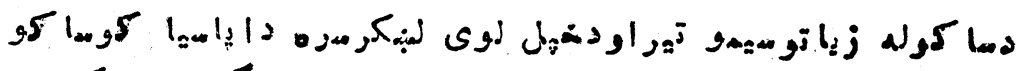

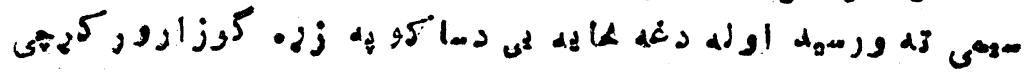

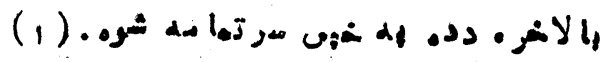

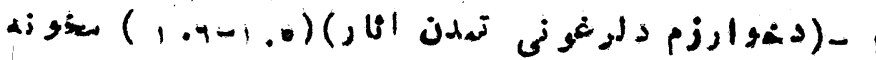


- $00-$

SI

Sم Satrap S

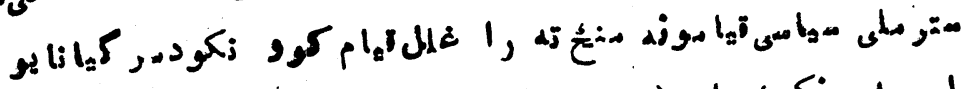

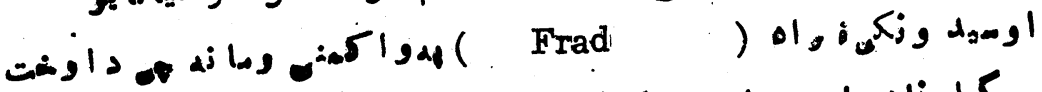

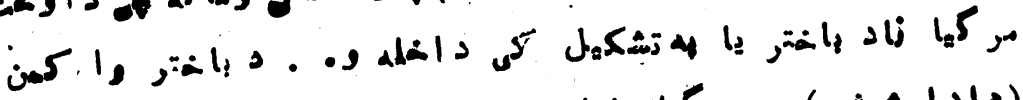

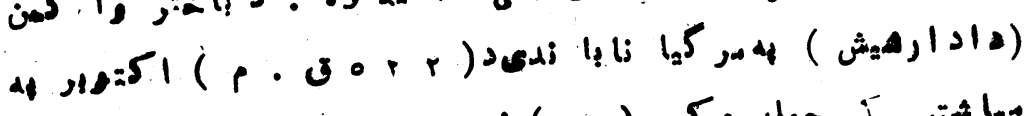

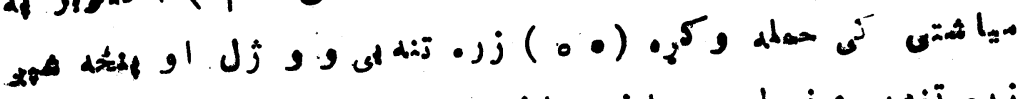

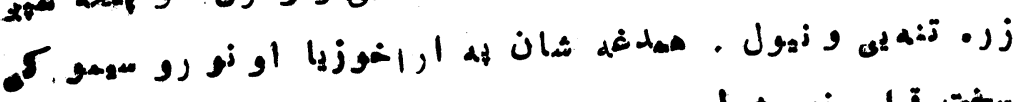

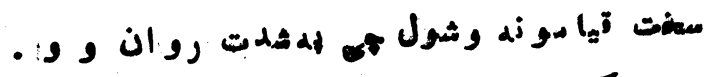

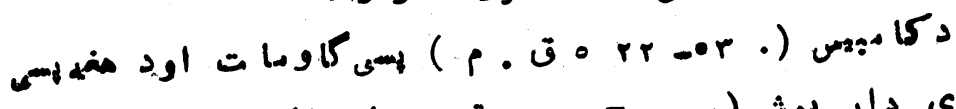

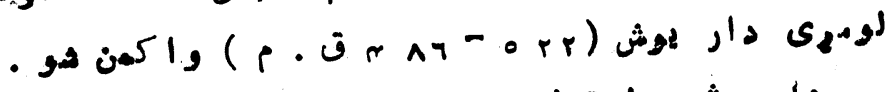

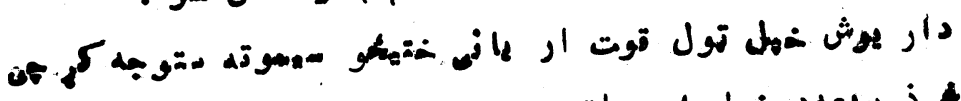

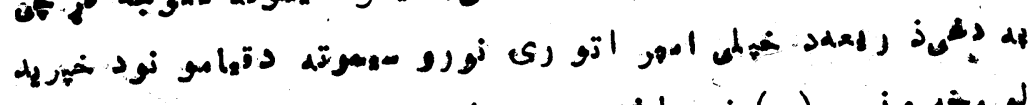

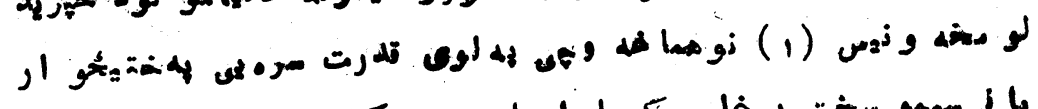

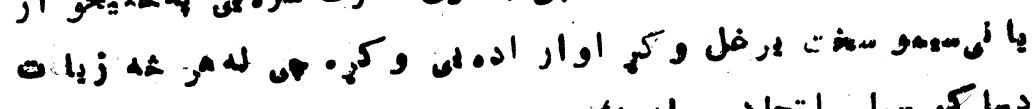

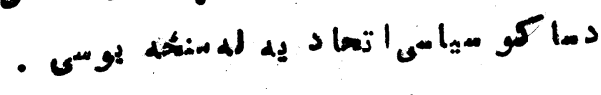

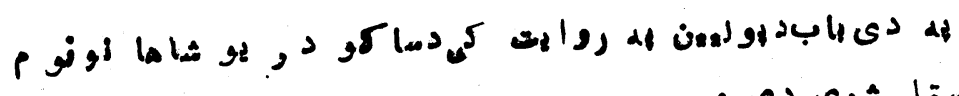

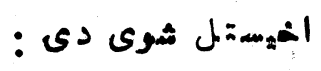

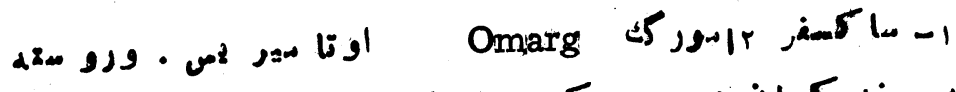

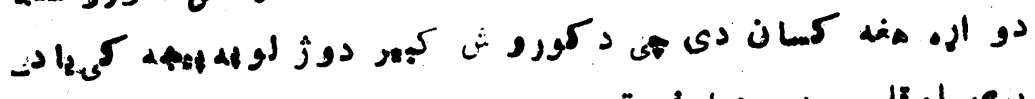

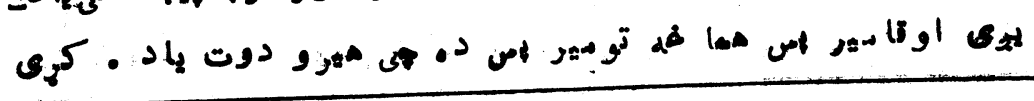

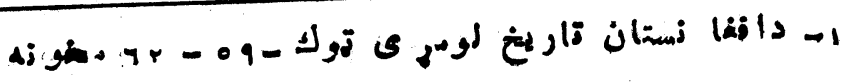


-. $0^{5}$ l.

$-07$

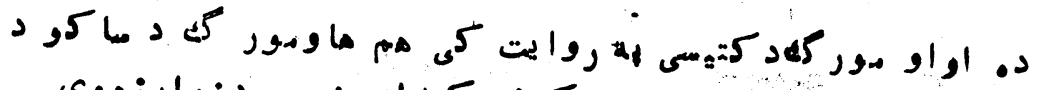

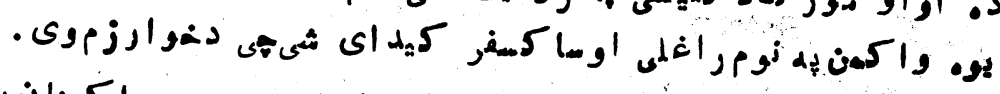

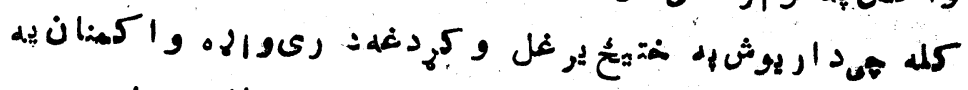

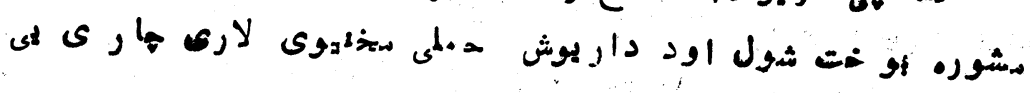

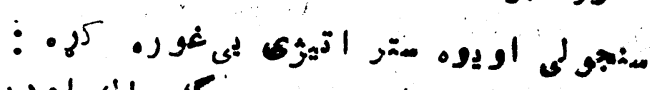

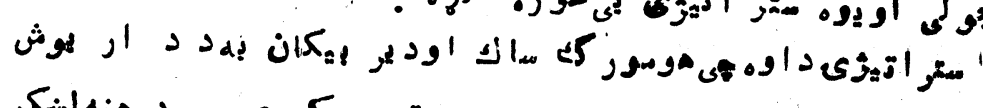

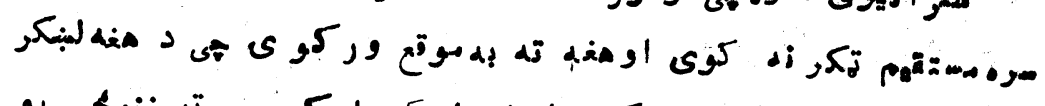

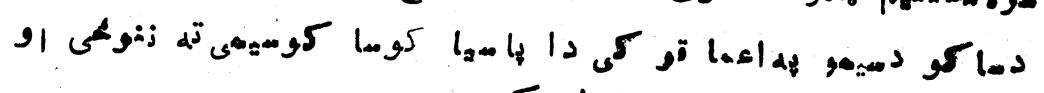

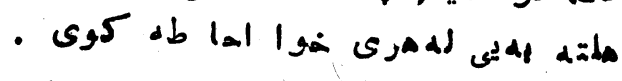

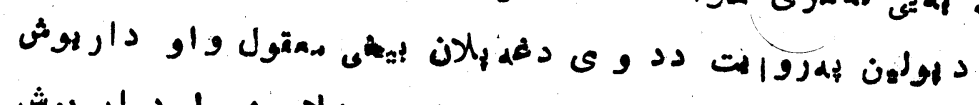

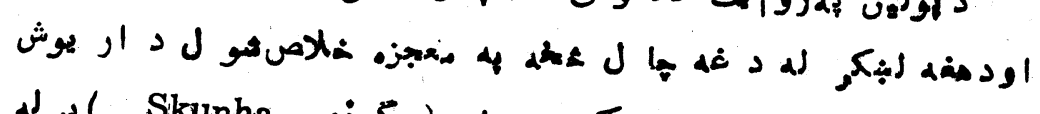

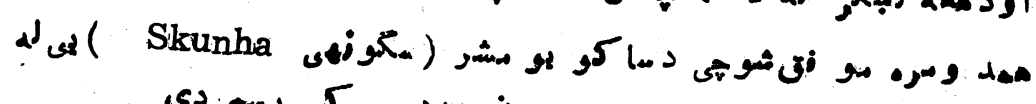

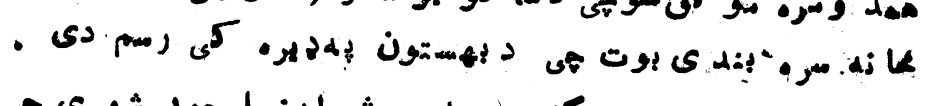

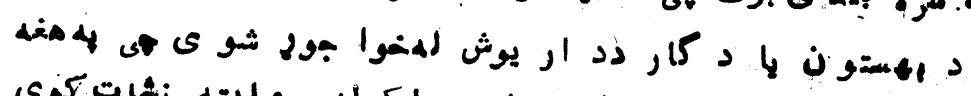

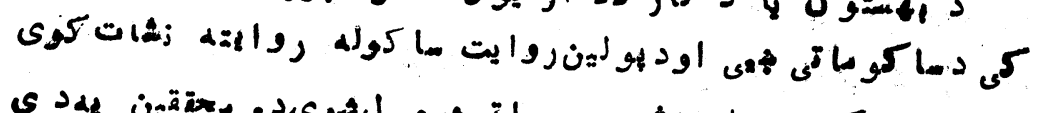

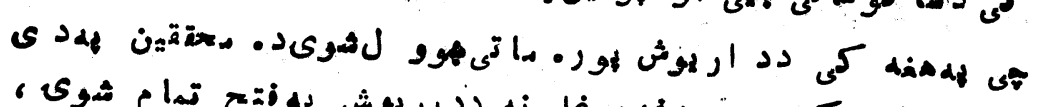

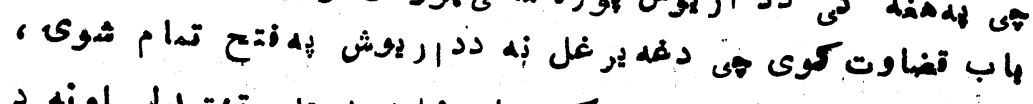

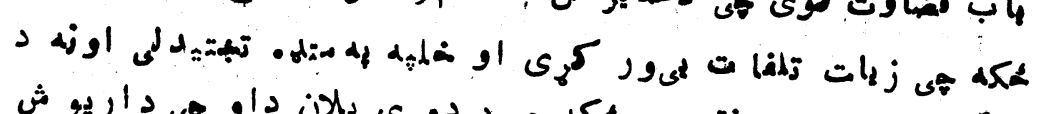

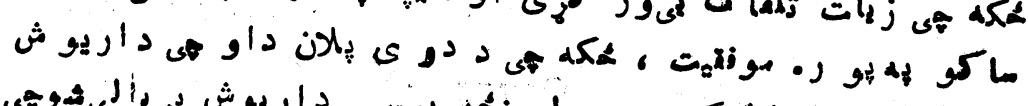

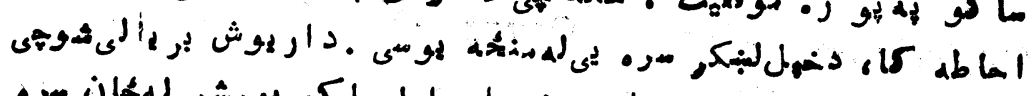

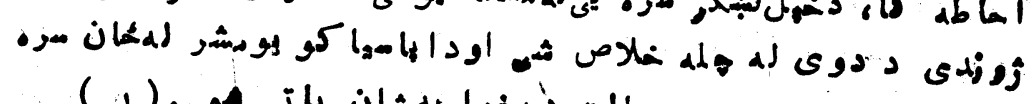

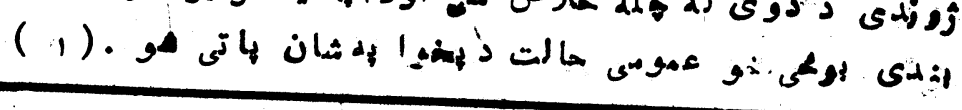

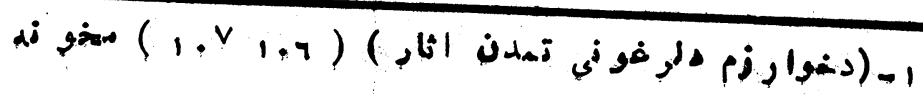


$-0^{2}$

كا

$$
\text { : }
$$

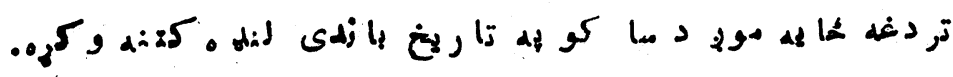

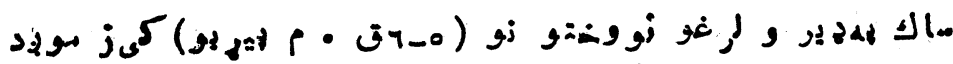

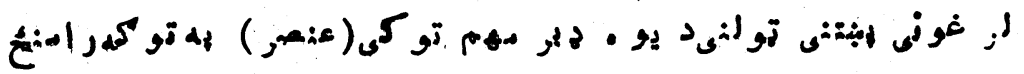

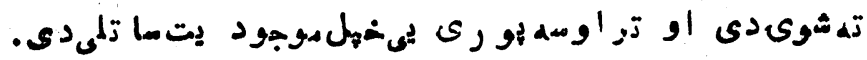

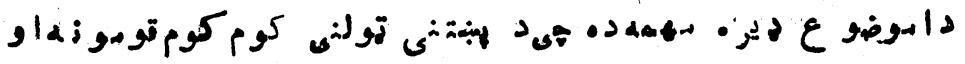

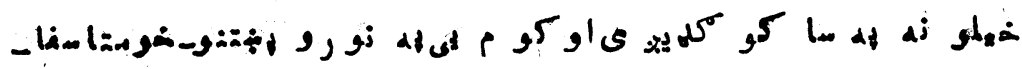

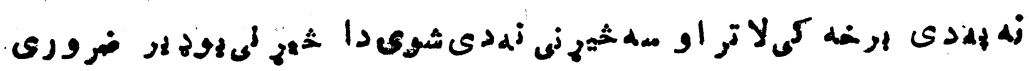

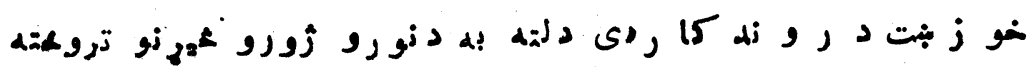

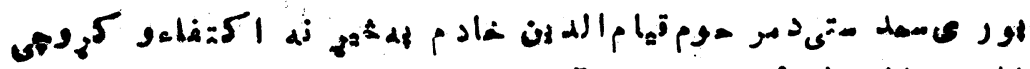

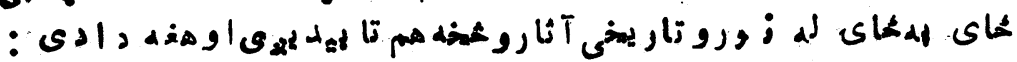

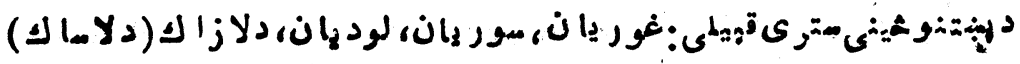

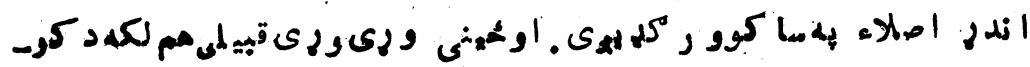

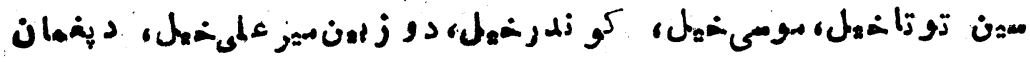

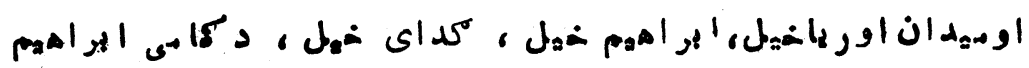

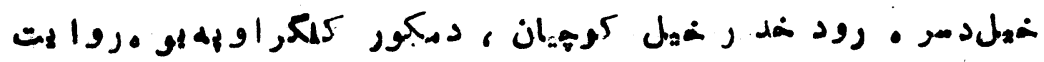

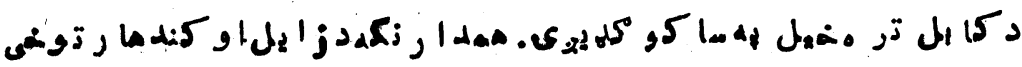

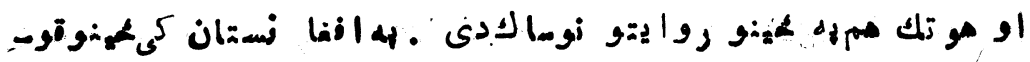

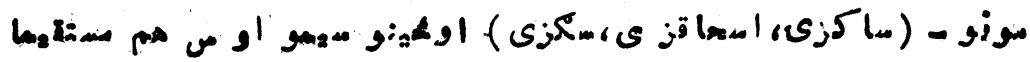

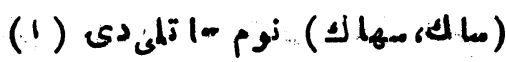

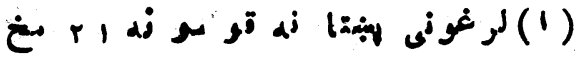




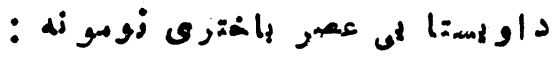

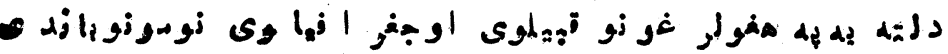
政

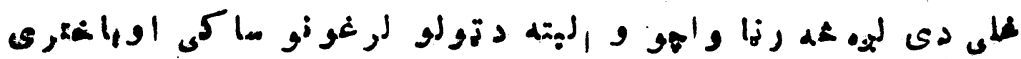

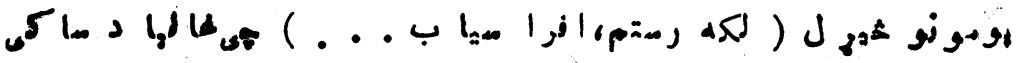

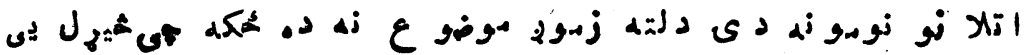

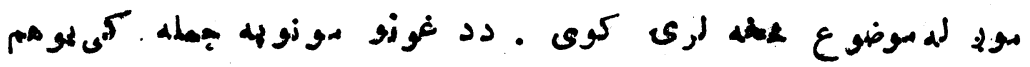

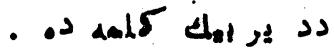

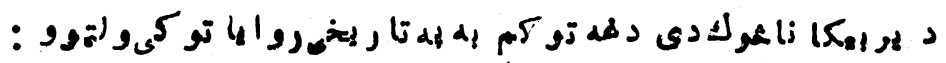

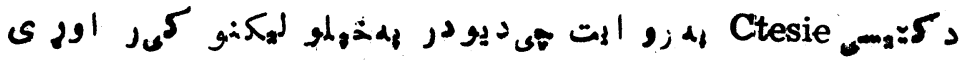

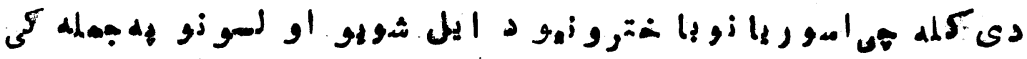

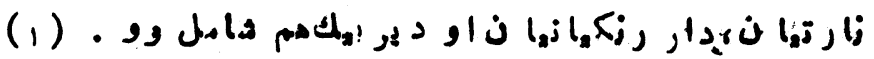

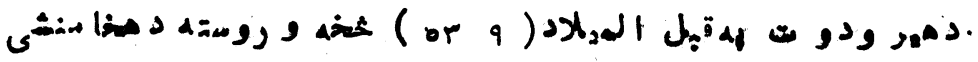

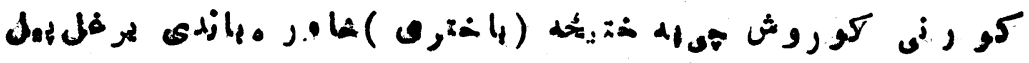

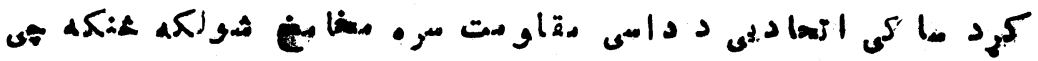

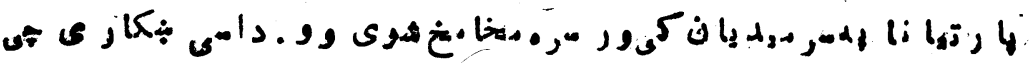

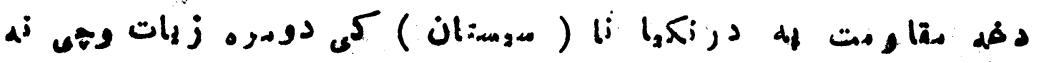

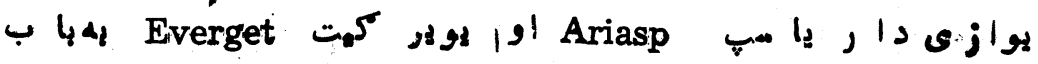

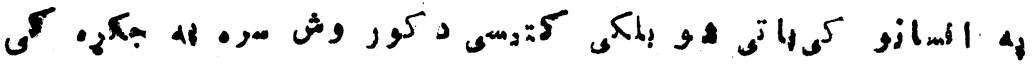

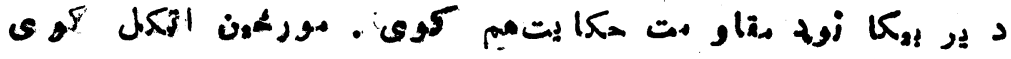

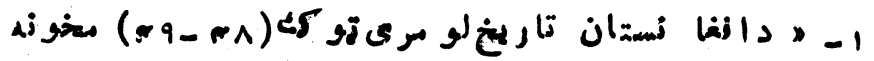


-・9-

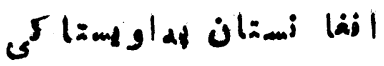

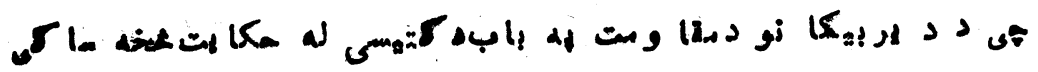

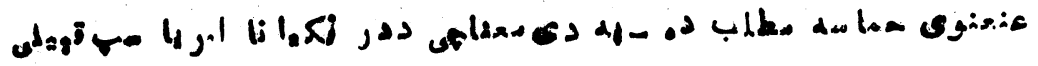

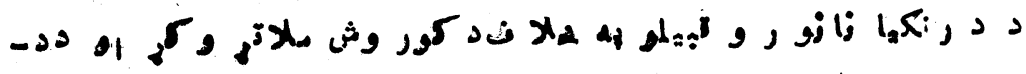

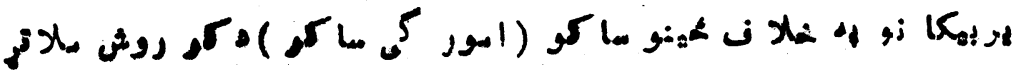

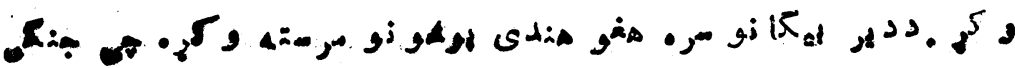

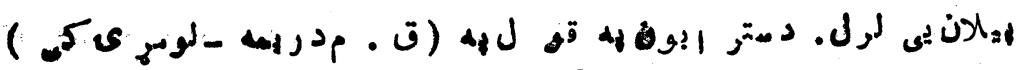

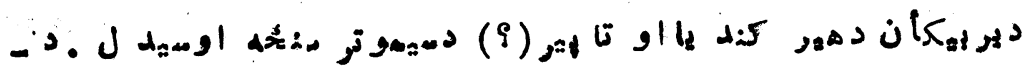

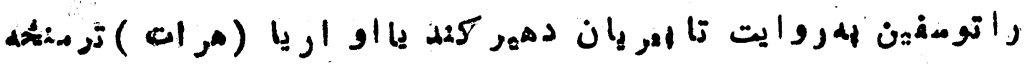

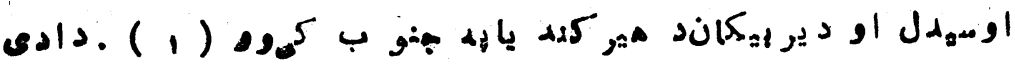

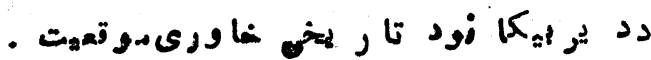

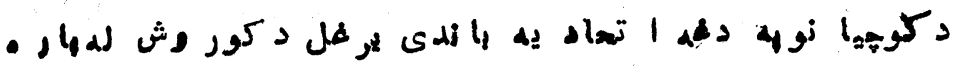

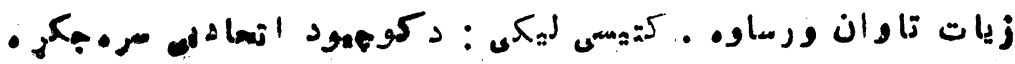

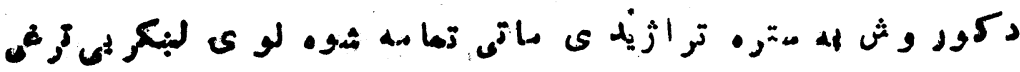

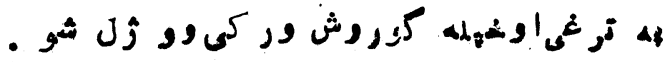

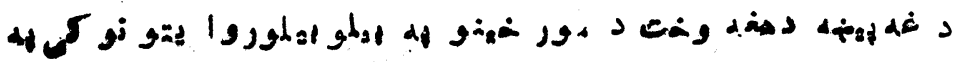

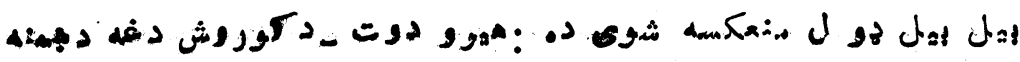

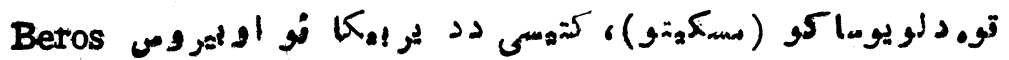

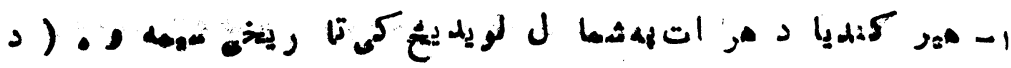

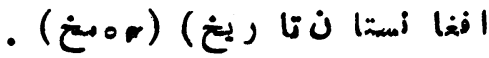




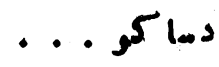

$-1 \cdot-$

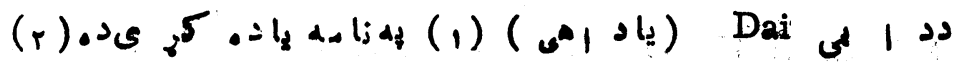

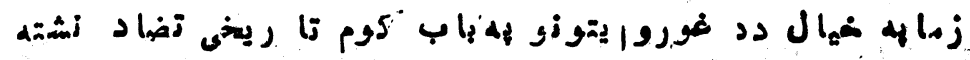

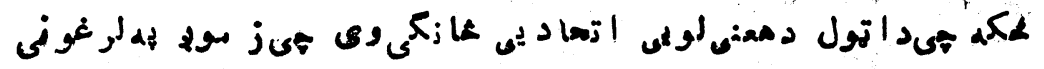

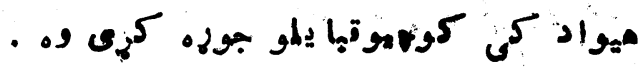

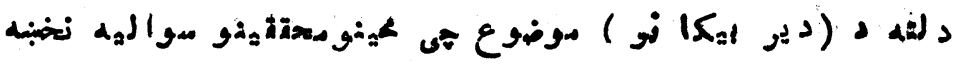

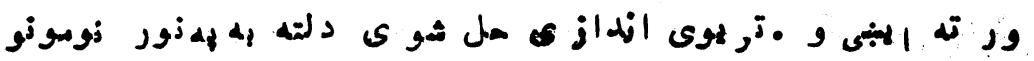

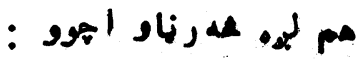

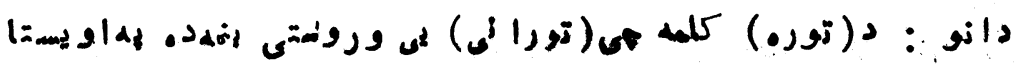

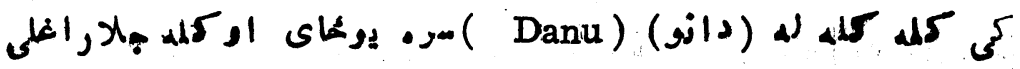

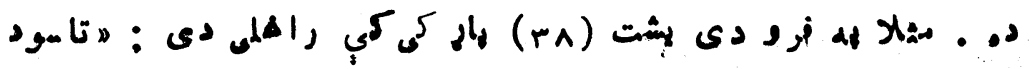

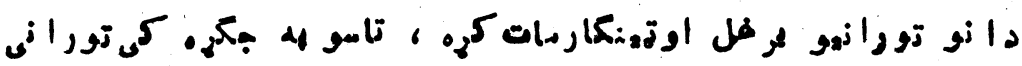

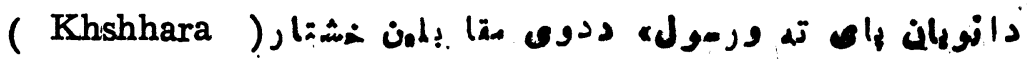

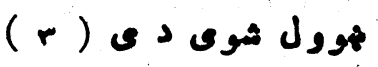

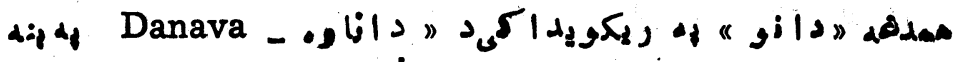

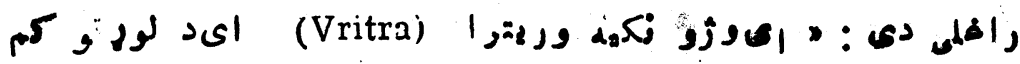

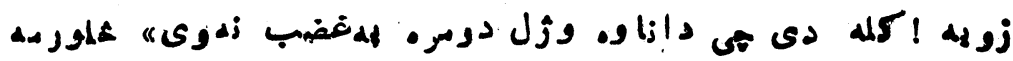

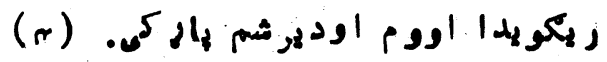

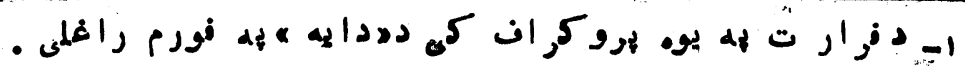

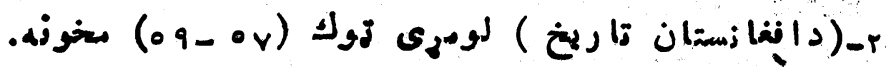

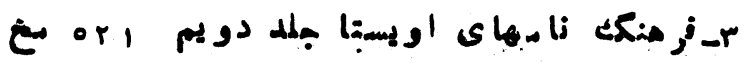

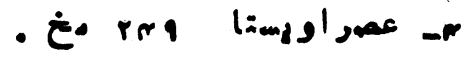




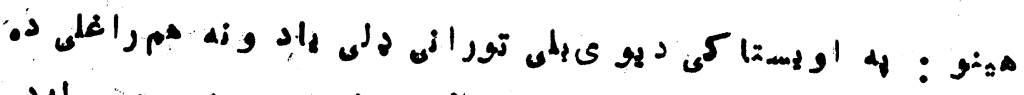

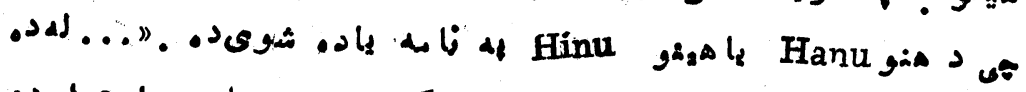

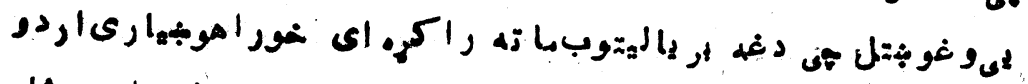

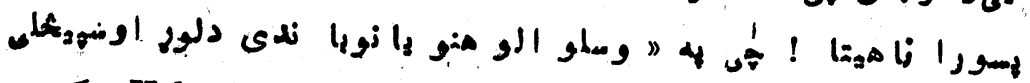

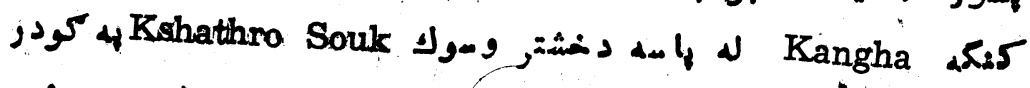

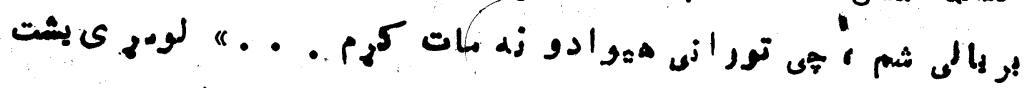

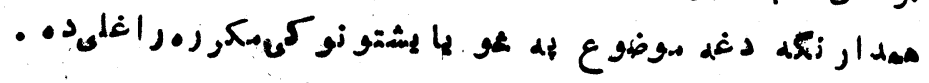

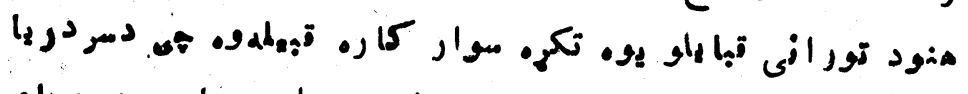

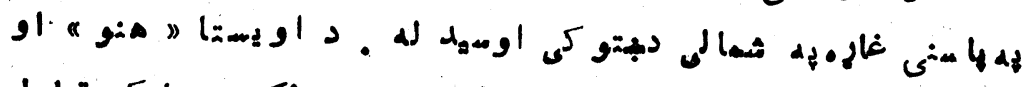

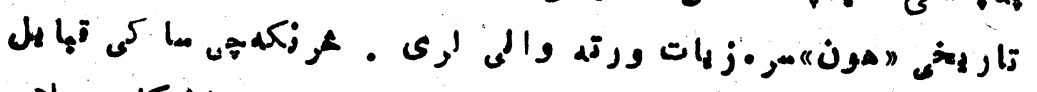

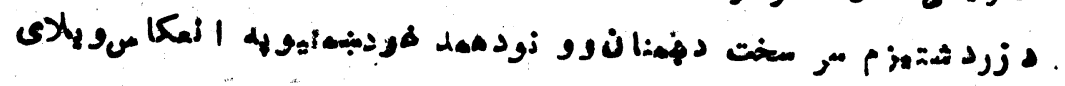

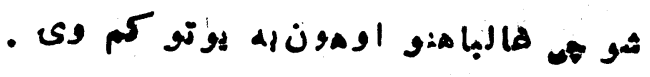

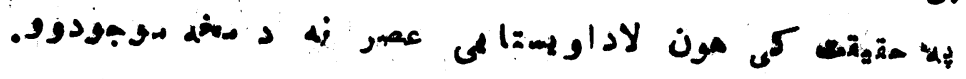

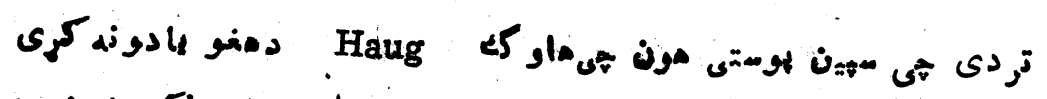

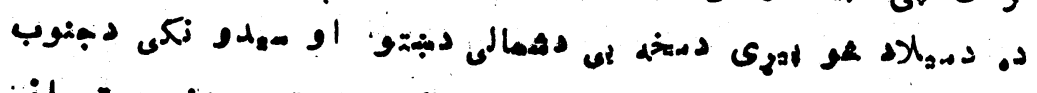

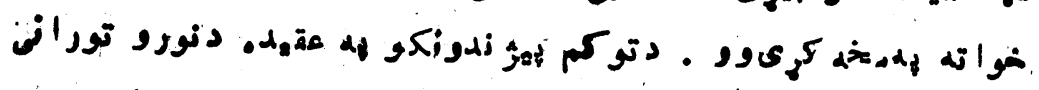

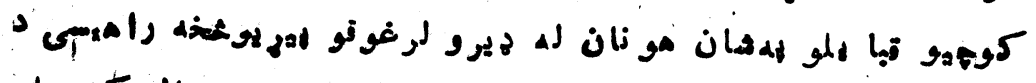

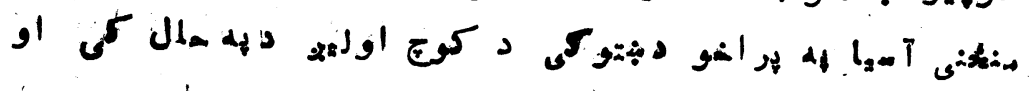
(i)

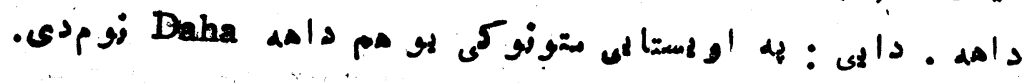

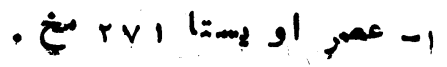


$-1 \%-$

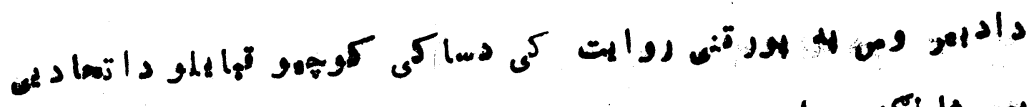

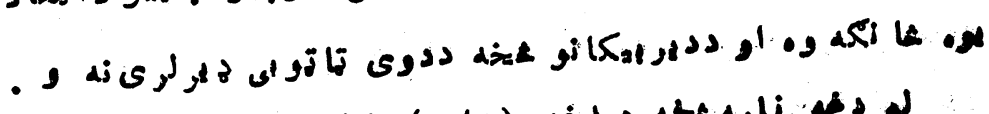

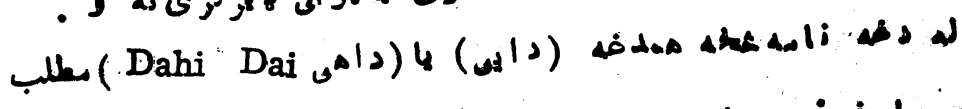

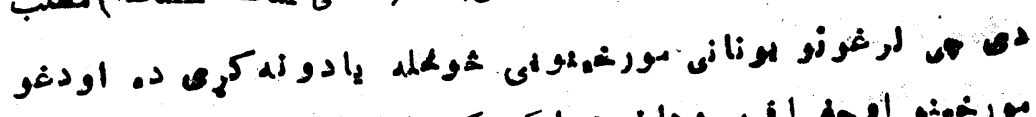

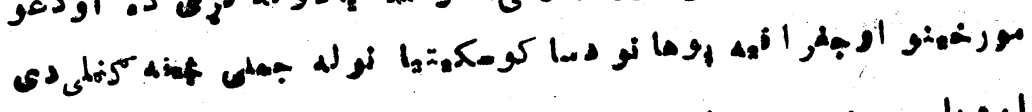

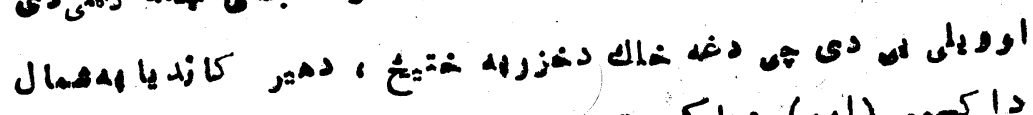

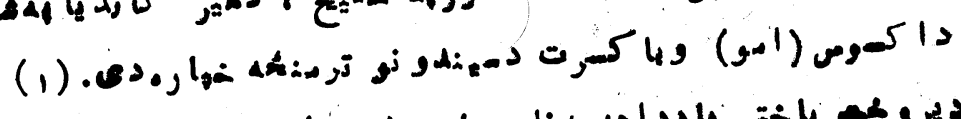

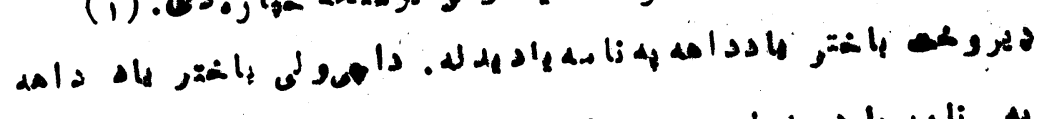

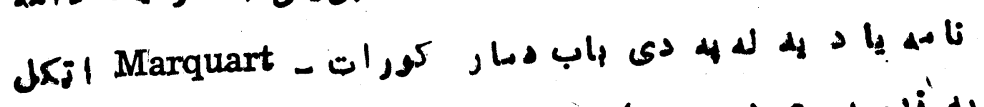

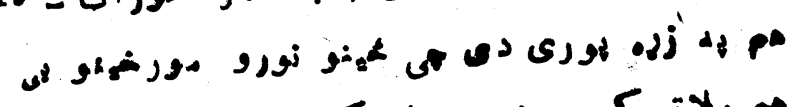

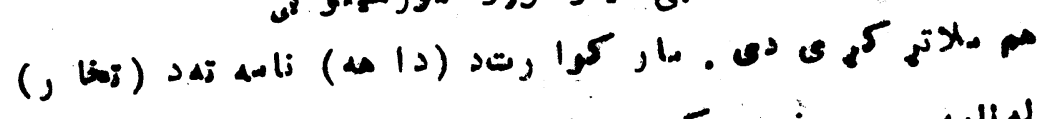

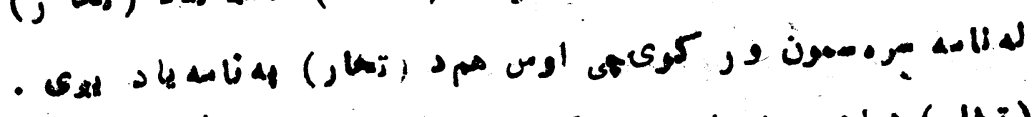

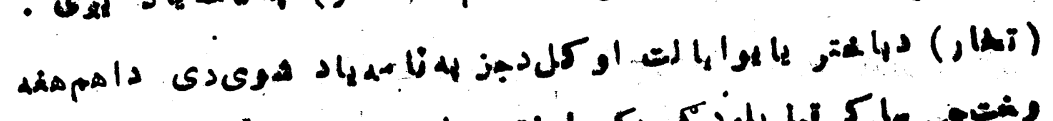

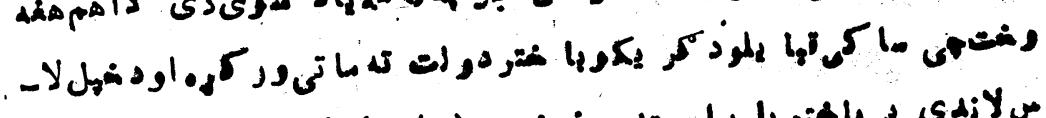

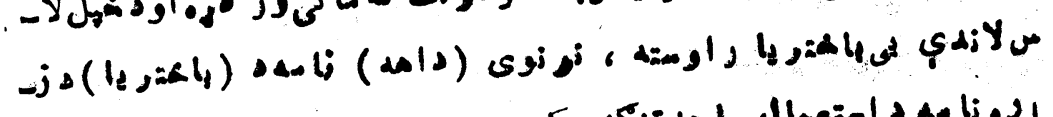

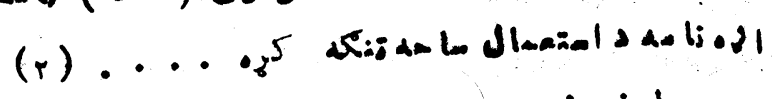

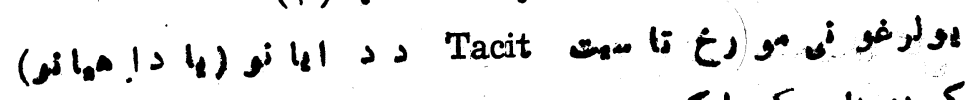

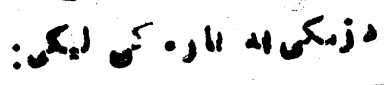

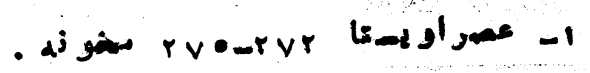

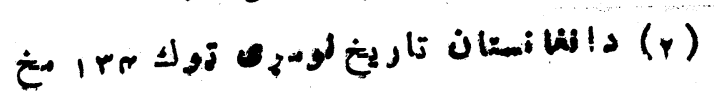




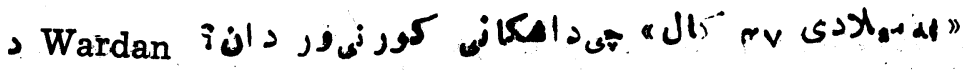

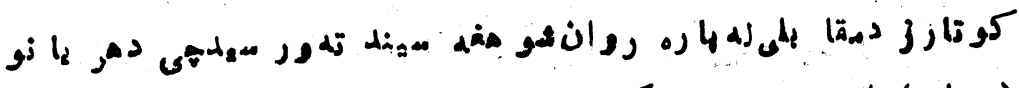

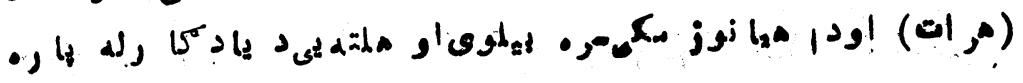

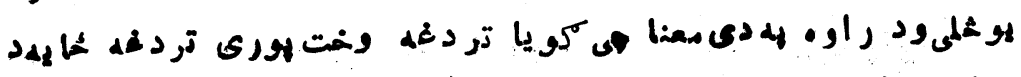

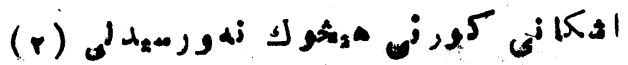

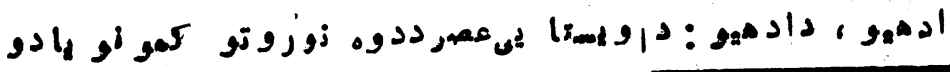

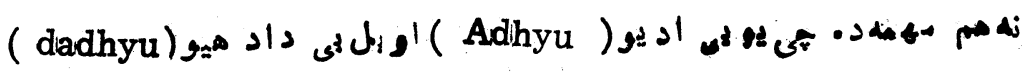

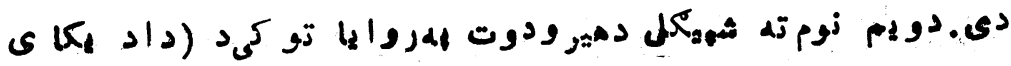
(dadicai)

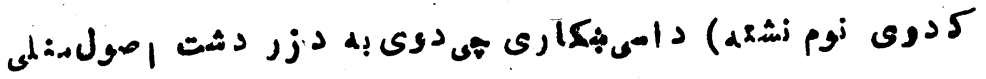

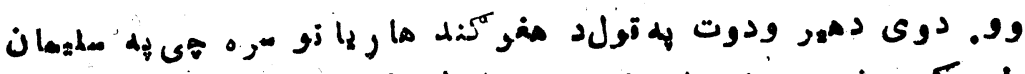

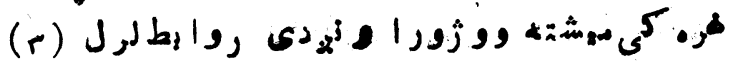

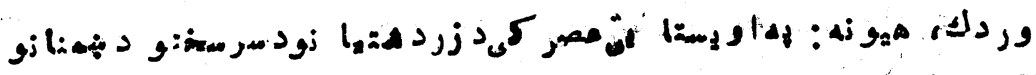

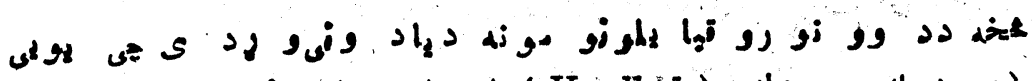

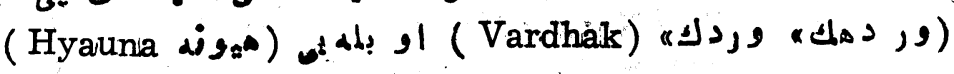

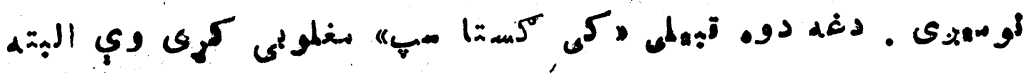

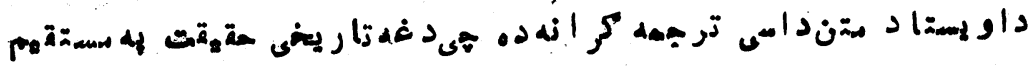

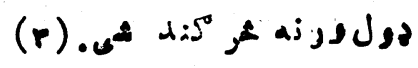

$$
\begin{aligned}
& \text { E ImA } \\
& \text { נ) } \\
& \text { J) } \\
& \text { נ) (1) }
\end{aligned}
$$

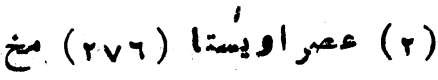

$$
\begin{aligned}
& \text { (rvr) (r) }
\end{aligned}
$$




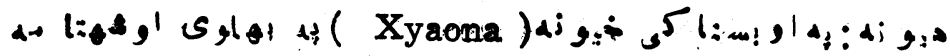

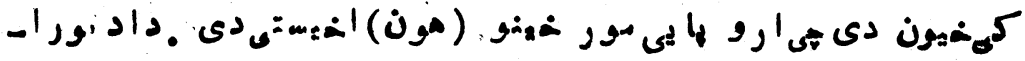

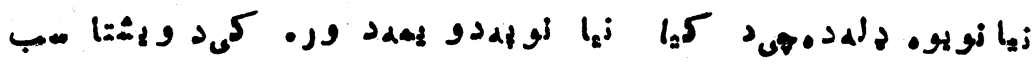

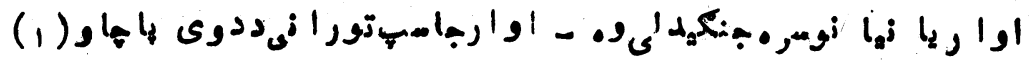

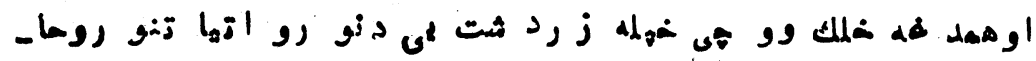

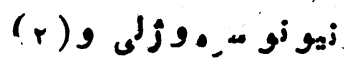

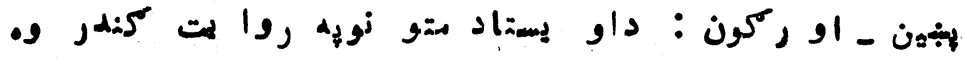

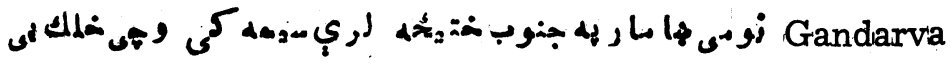

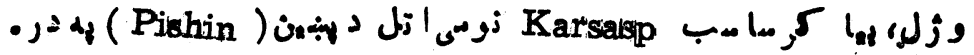

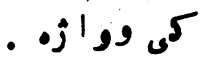

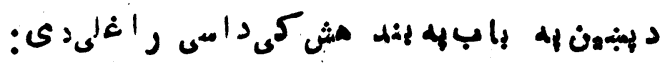

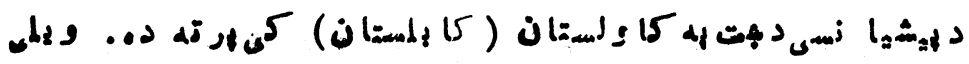

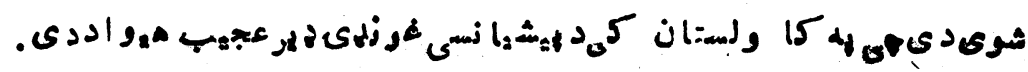

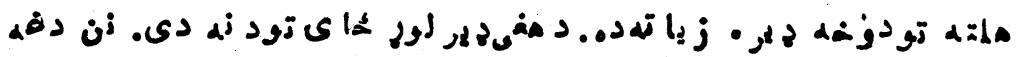

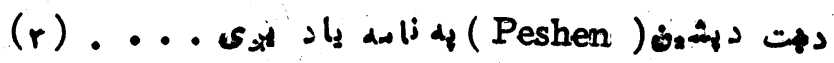

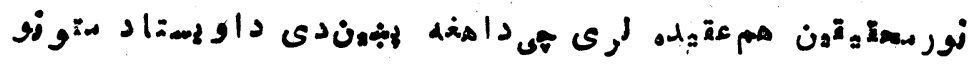

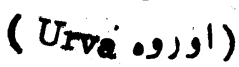

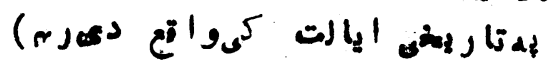

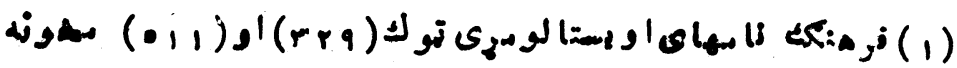

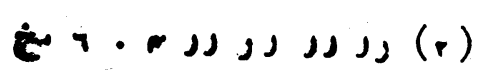

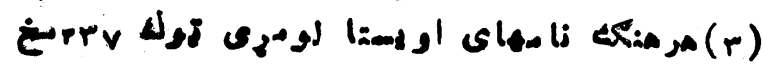

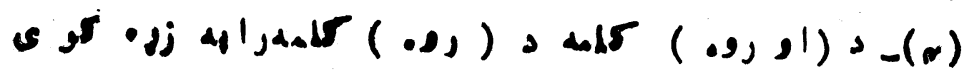


$-10-$

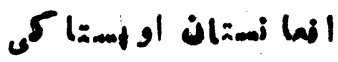

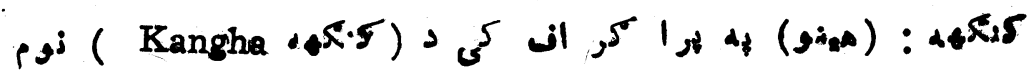

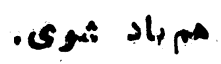

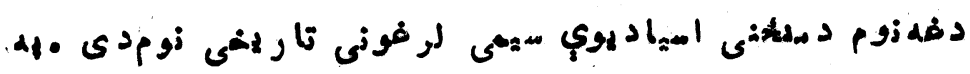

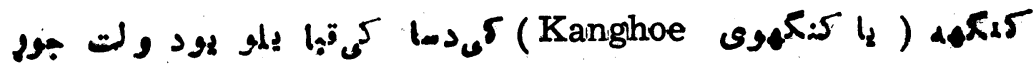

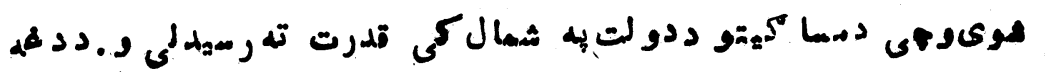

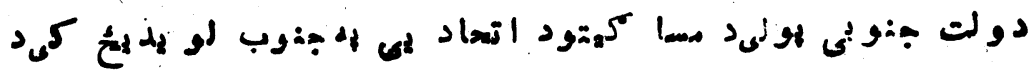

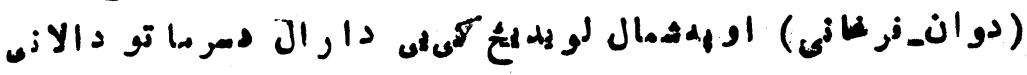

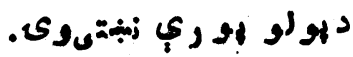

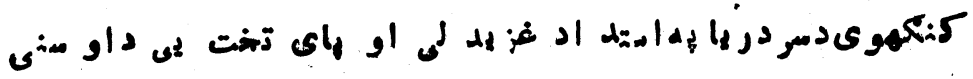

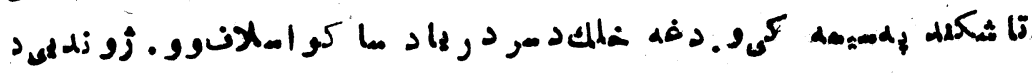

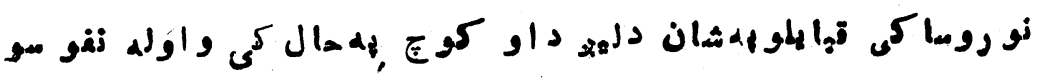

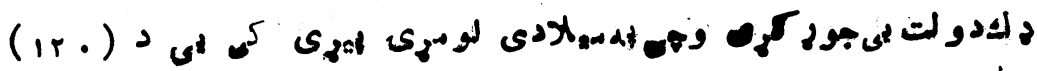

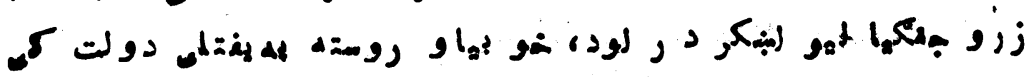

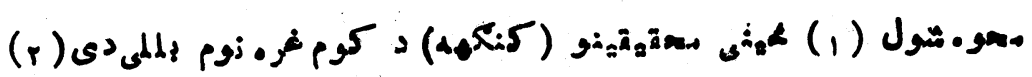

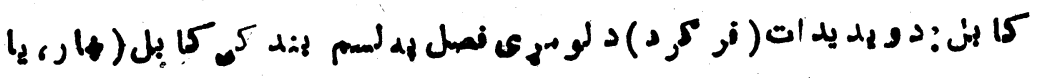

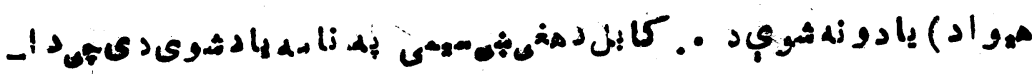

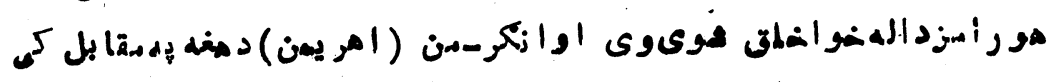

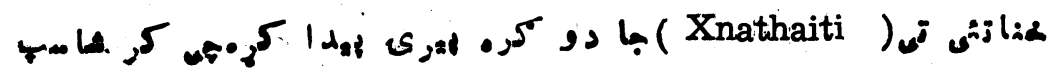

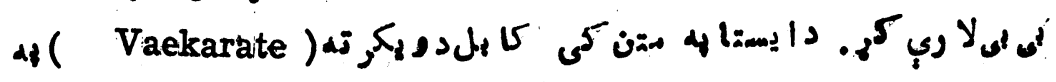

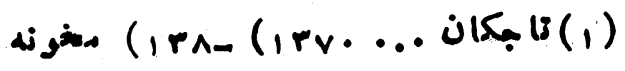

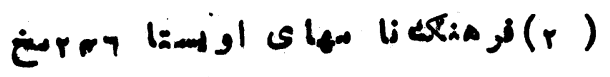




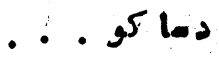

-99

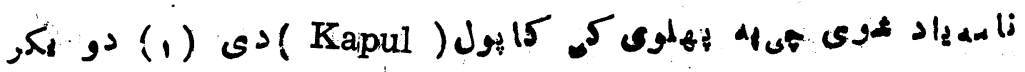

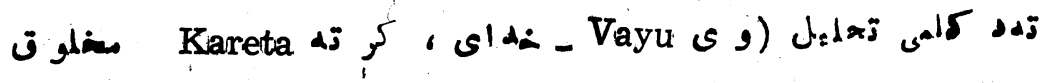

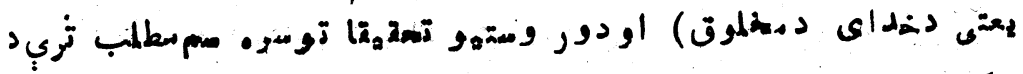
(r) (r)

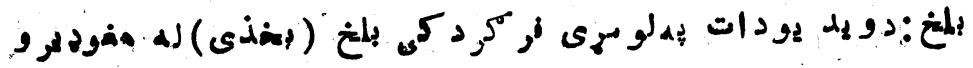

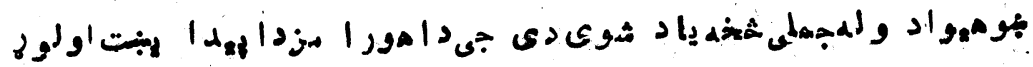

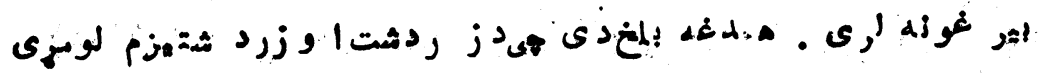

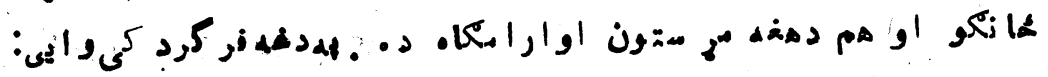

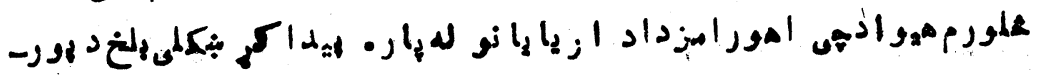

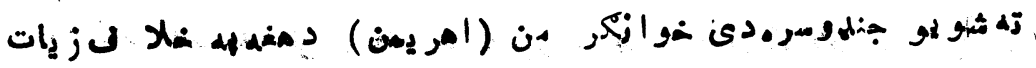

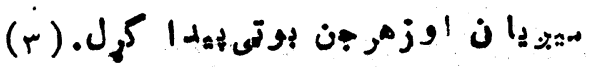

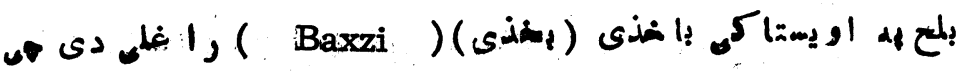

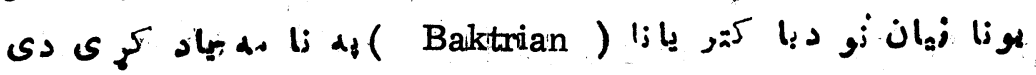
S

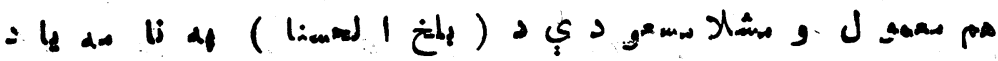

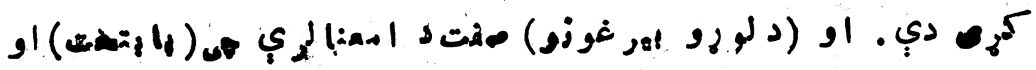

(r)

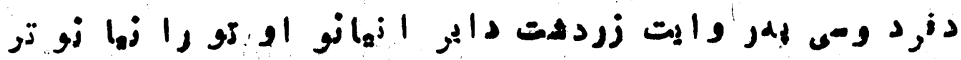

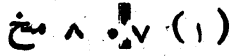

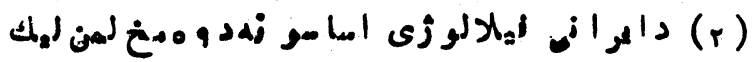

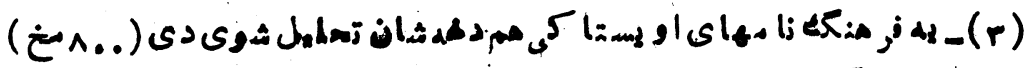

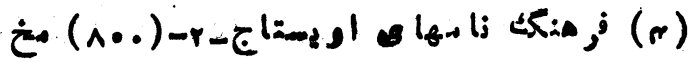


$-7 v$

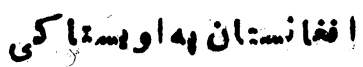

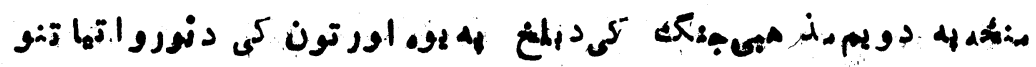

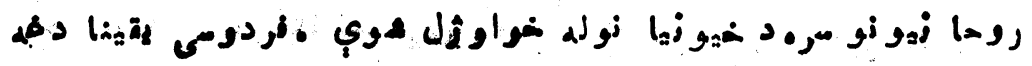

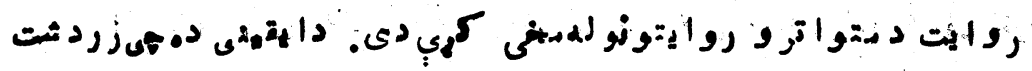

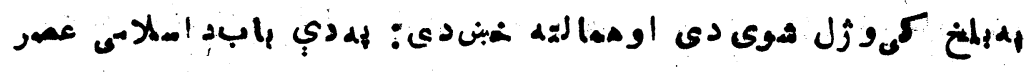

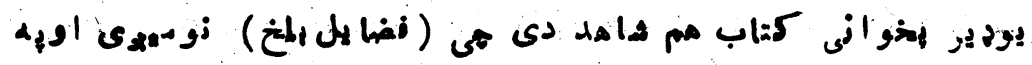

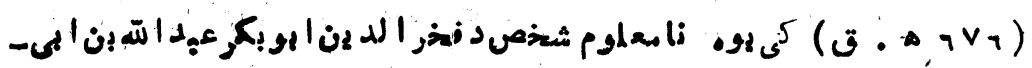

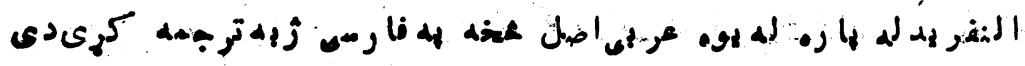

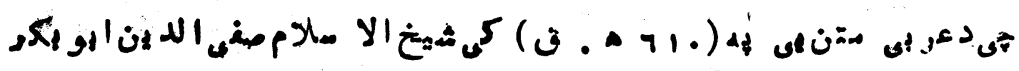

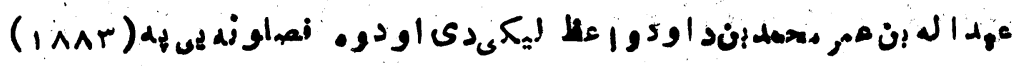

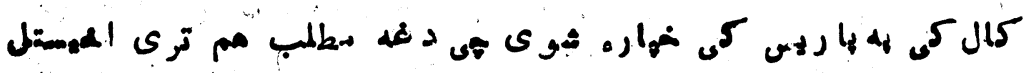

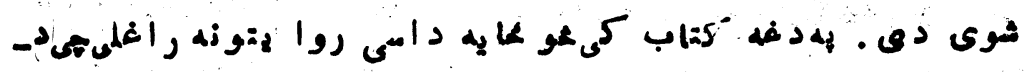

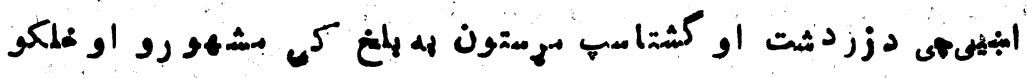

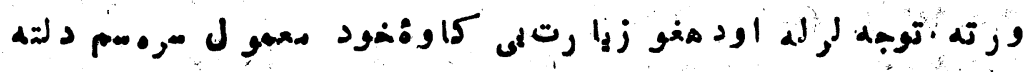

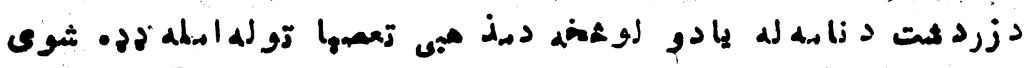

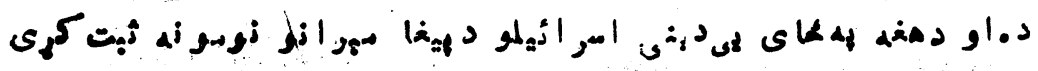

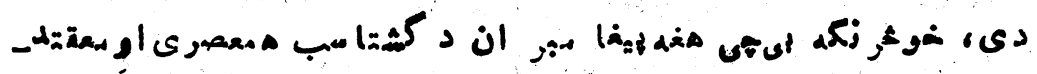

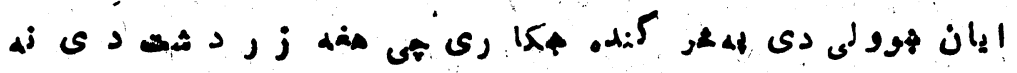

(1)

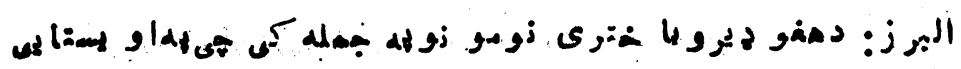

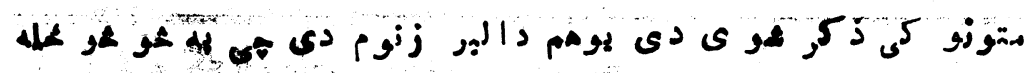

رأهل

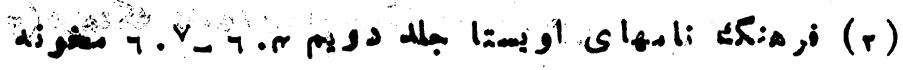


$\therefore$.

$-71$

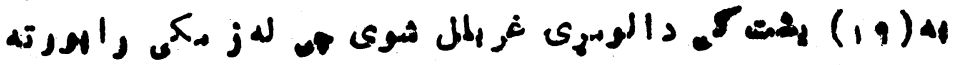

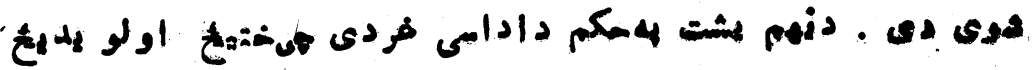

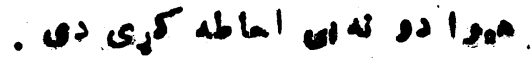

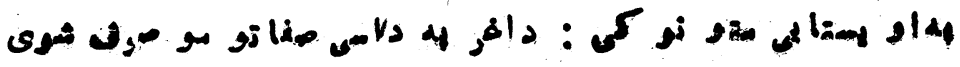

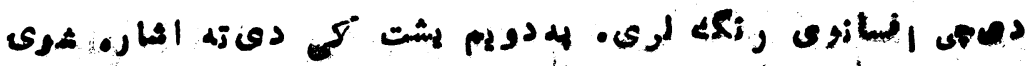

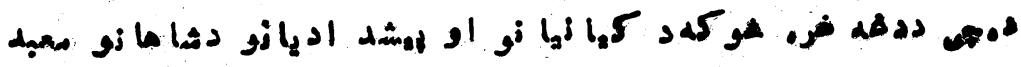
- و (1)

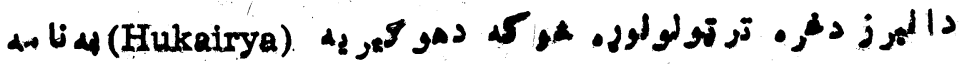

(r) . ocest osh

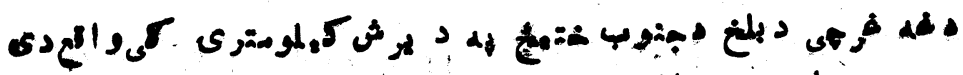
ارو

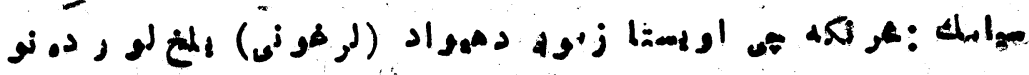
a)

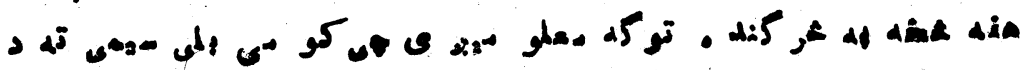

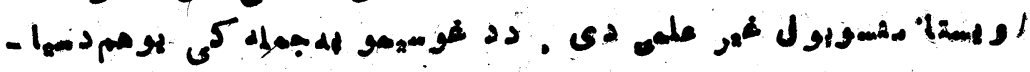

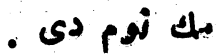

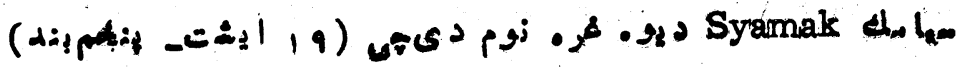

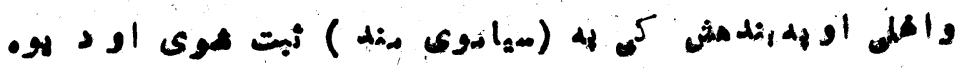

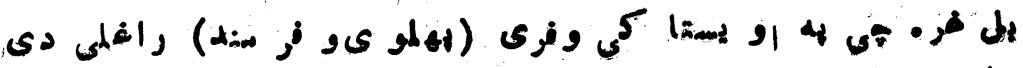

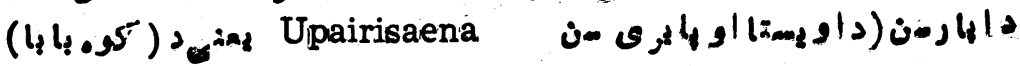
(r) (r )

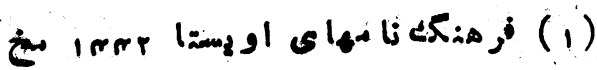

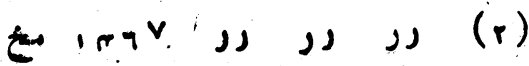

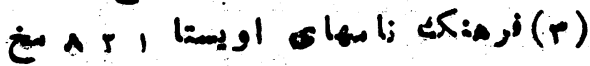


$-790$

Fl

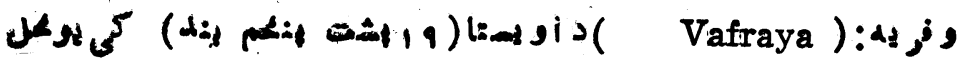

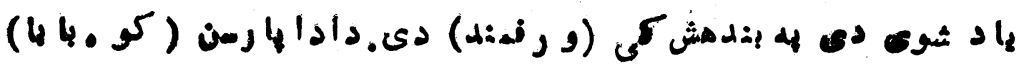

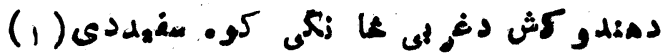

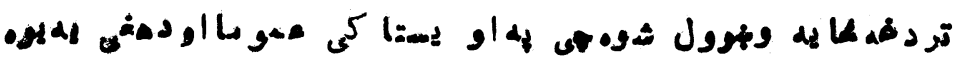

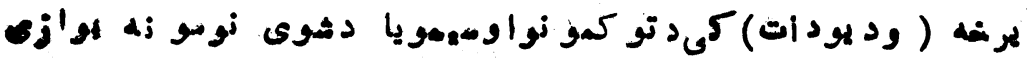

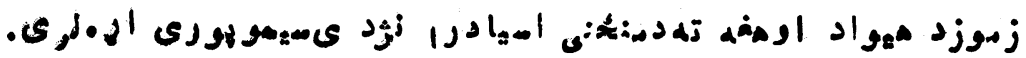

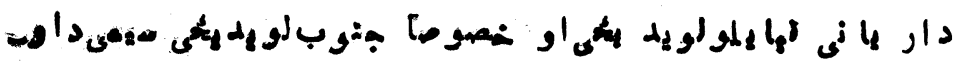

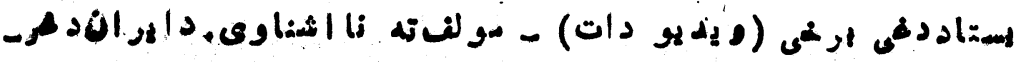

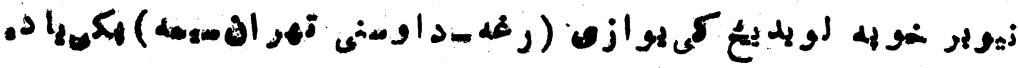

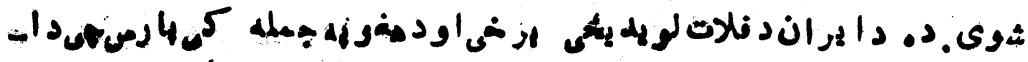

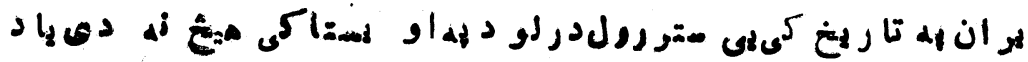

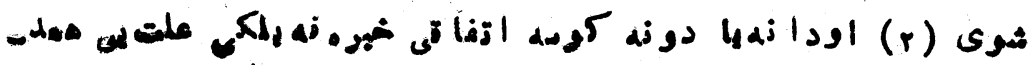

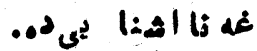

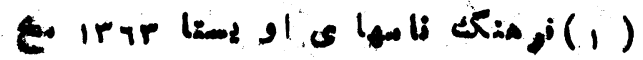

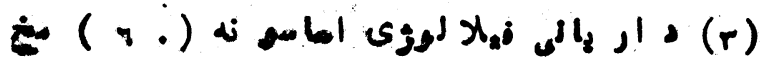




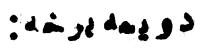

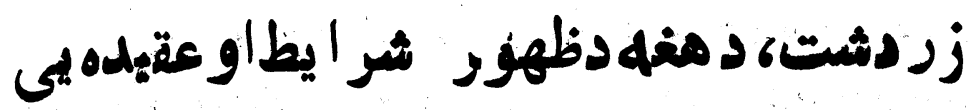

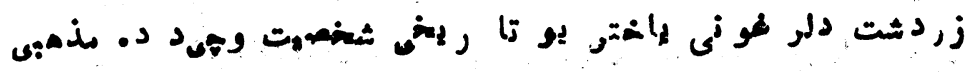

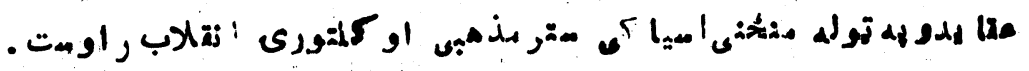

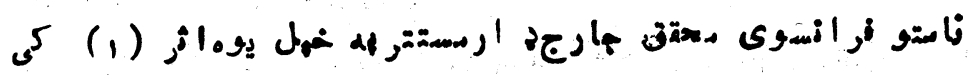

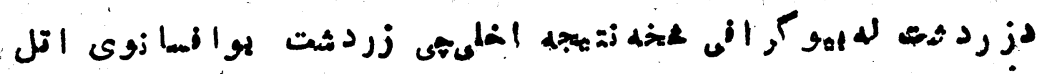

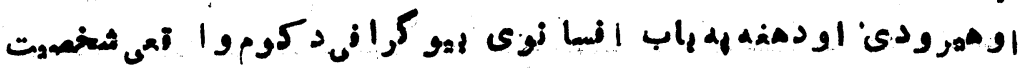

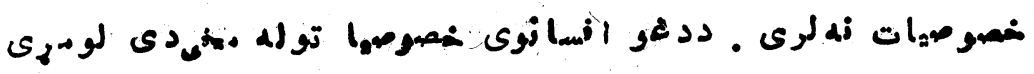

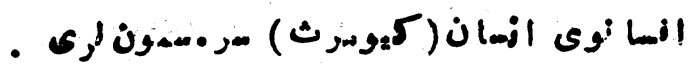

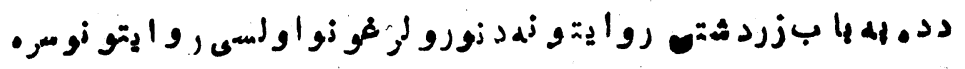

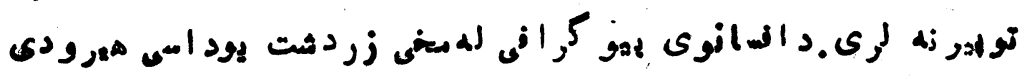

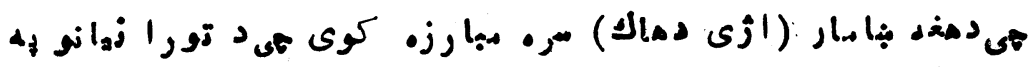

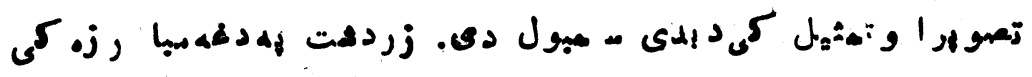

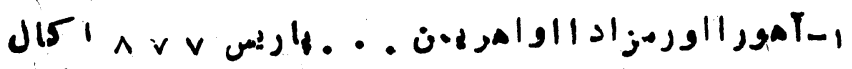




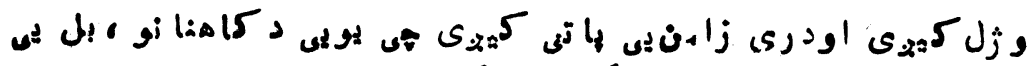

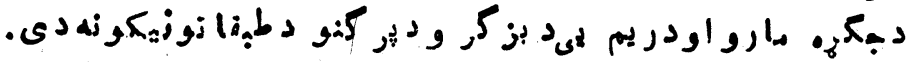

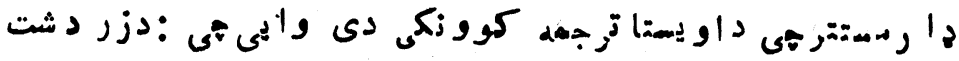

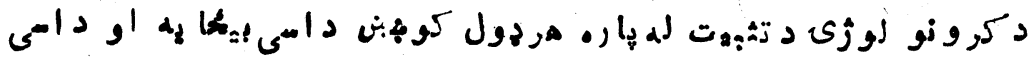

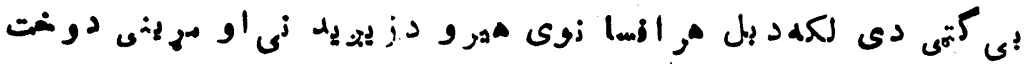

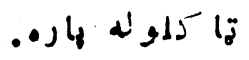

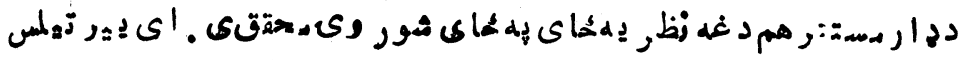

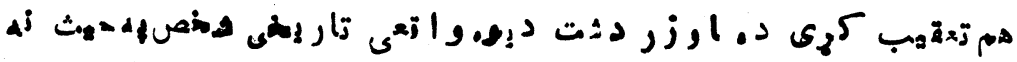

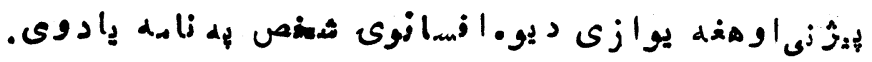

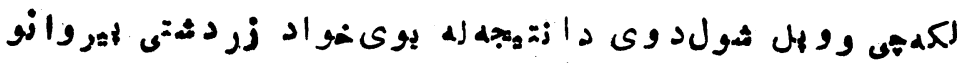

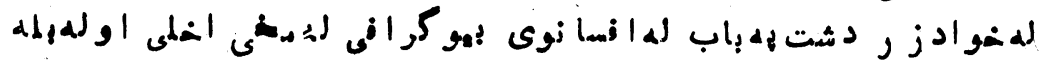

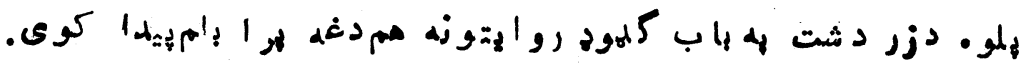

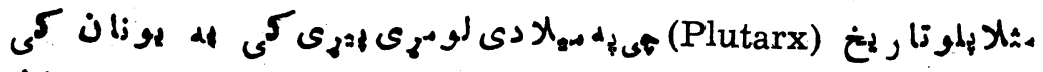

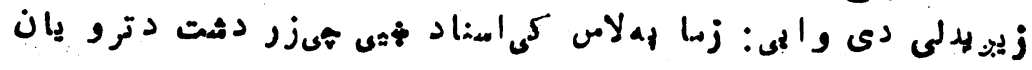
(Troean)

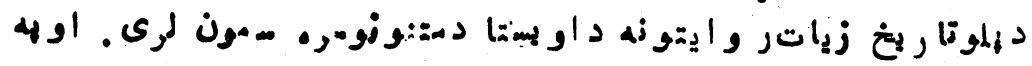

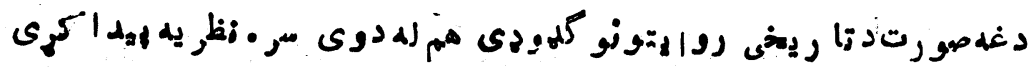

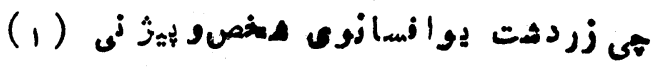

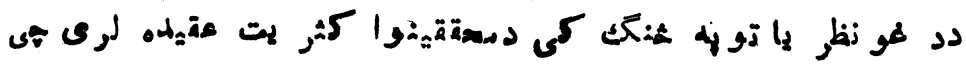

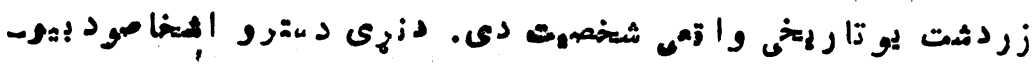

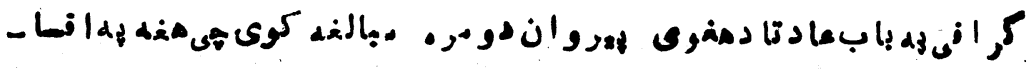

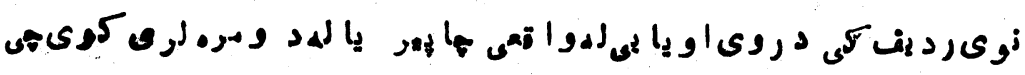

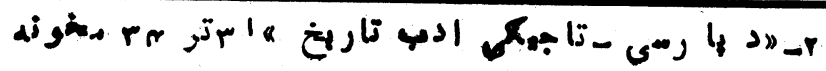




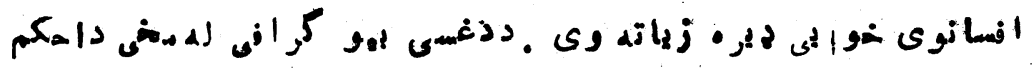

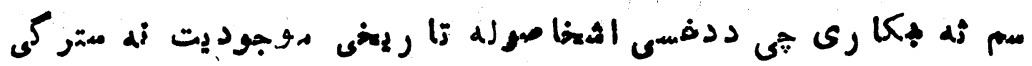

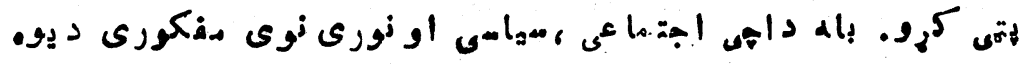

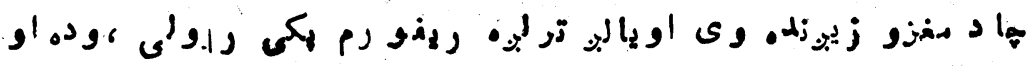

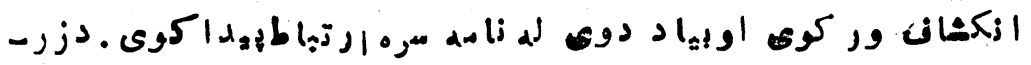

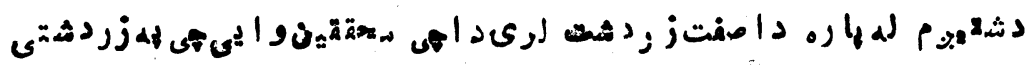

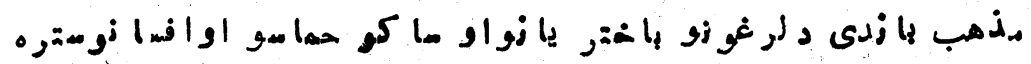

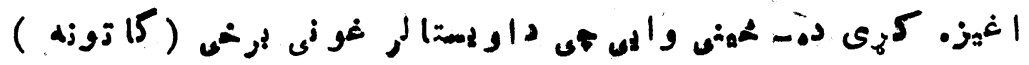

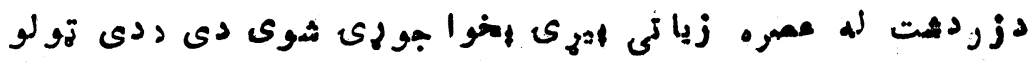

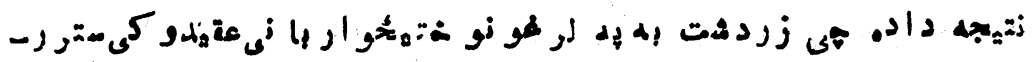

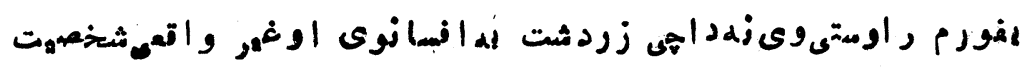

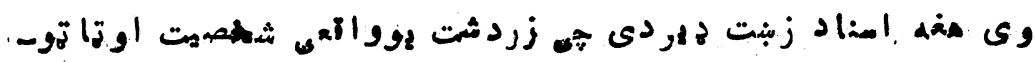

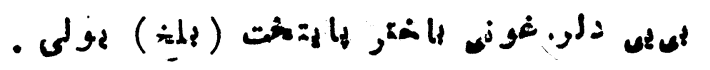

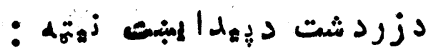

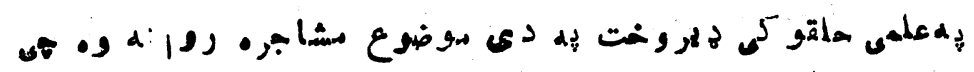

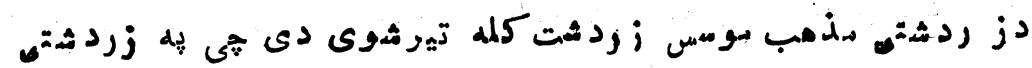

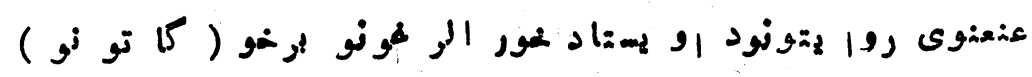
مولن دى دئ

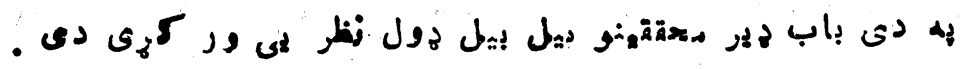

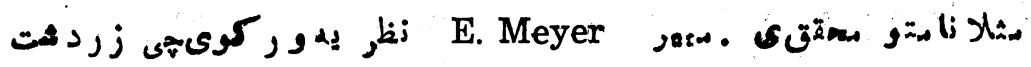

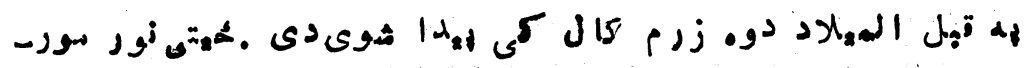

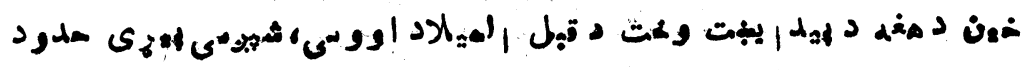




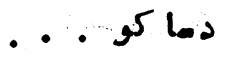

$-v_{r}$

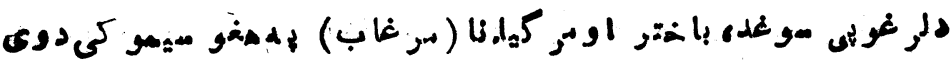

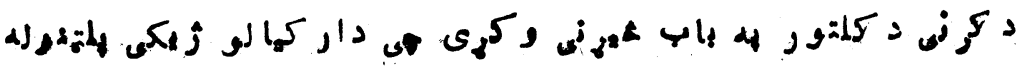

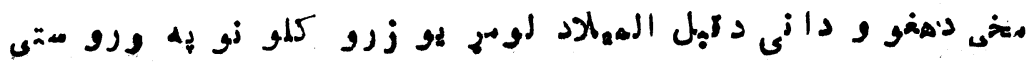

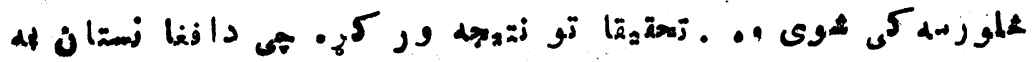

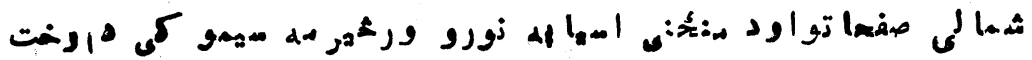

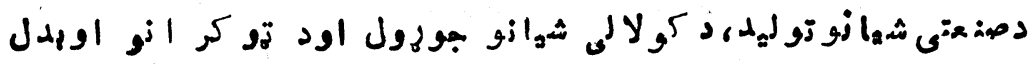

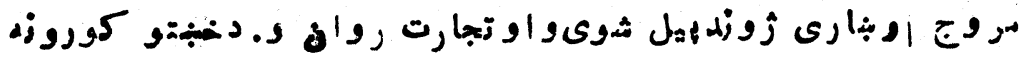

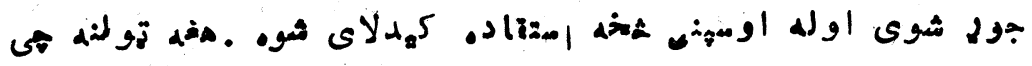

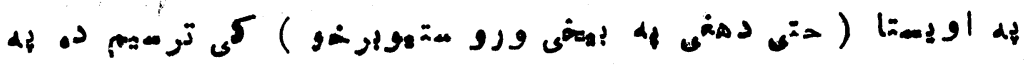

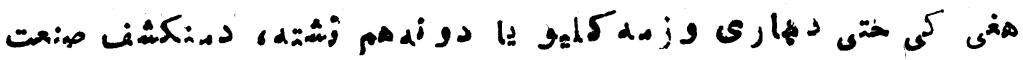

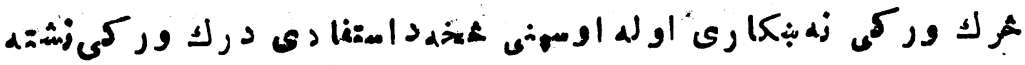

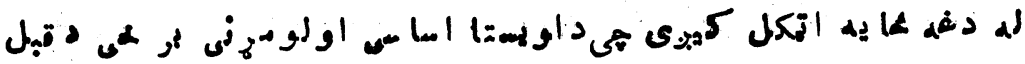

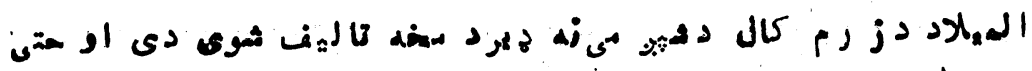

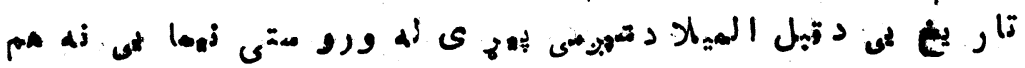

- v د د د

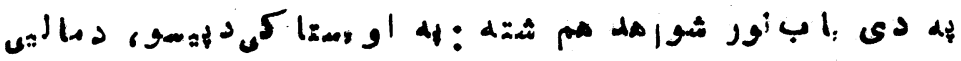

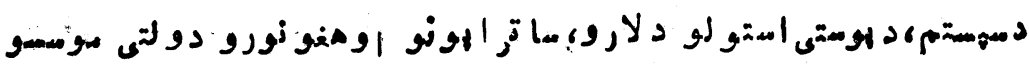

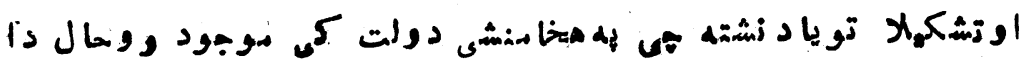

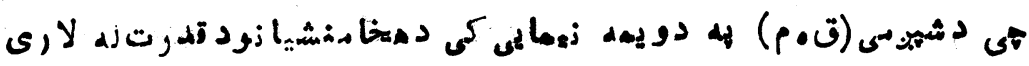

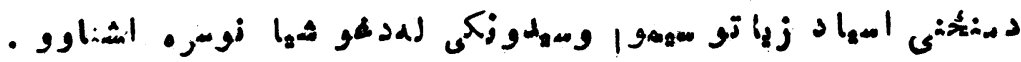

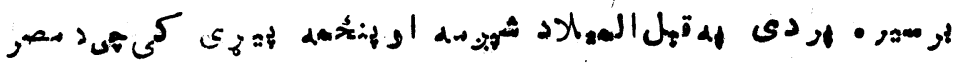

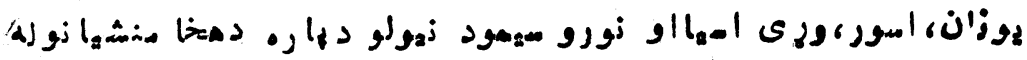




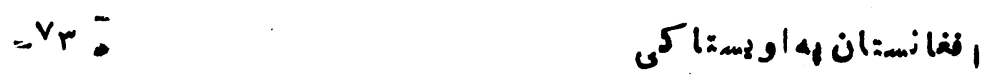

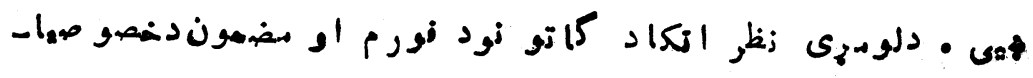

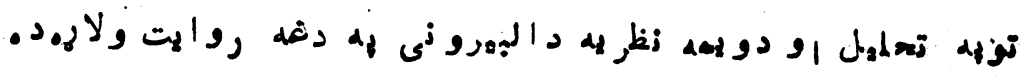

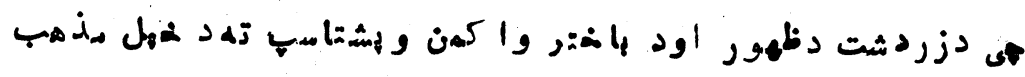

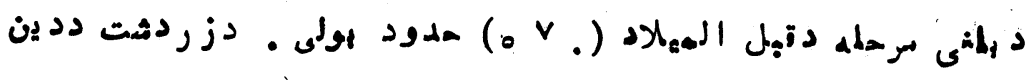

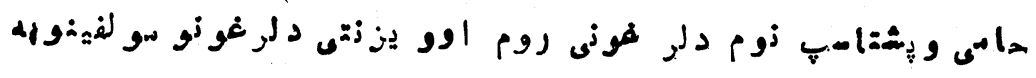

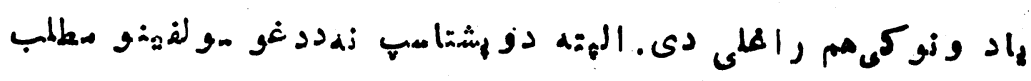

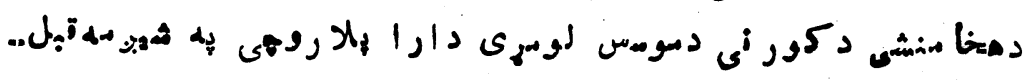

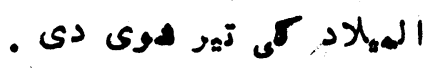

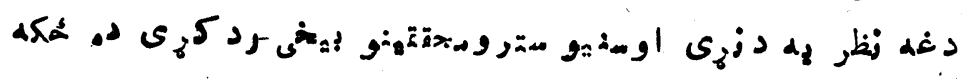

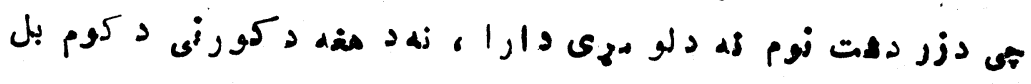

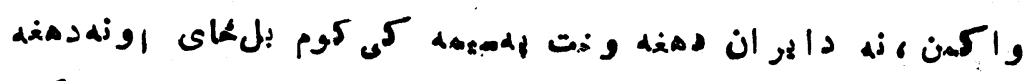

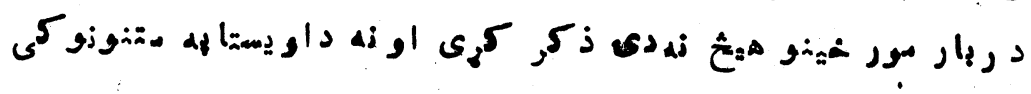

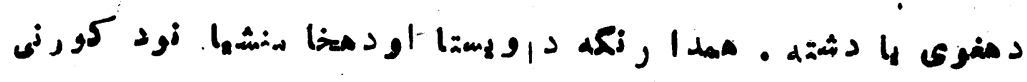

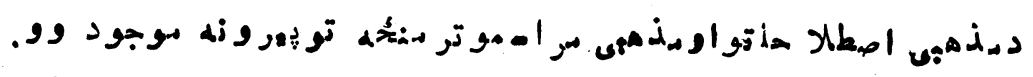
مall

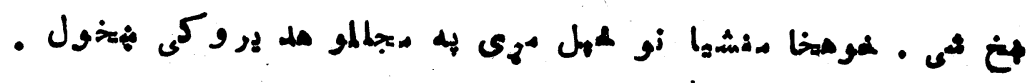

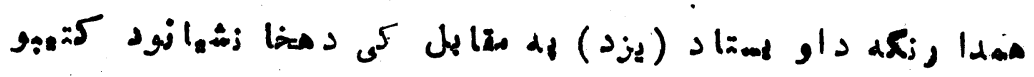

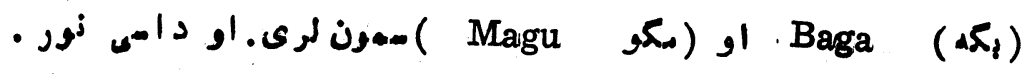

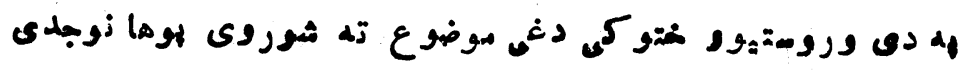

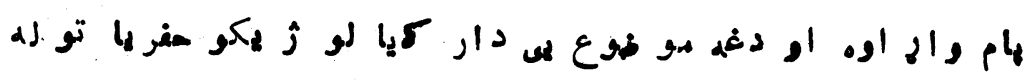

- لا رى 
$-v_{0}-$

S lavgl

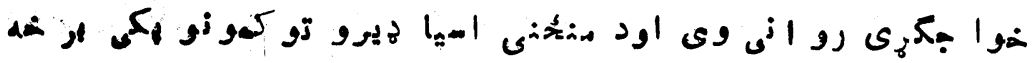

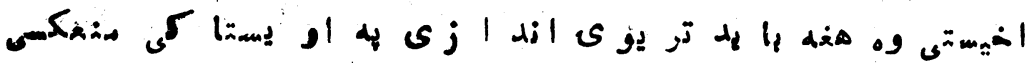

مونى وانى

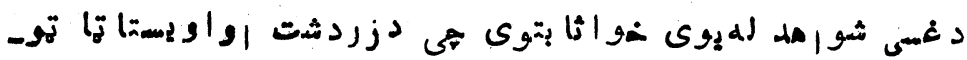

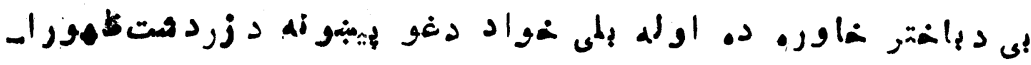

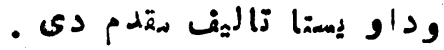

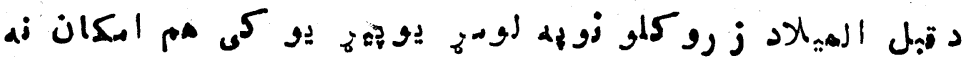

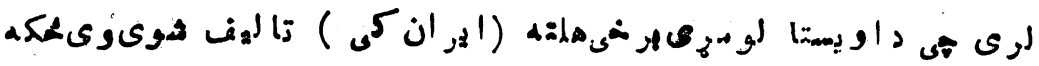

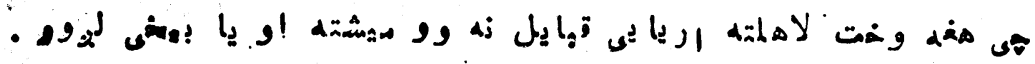

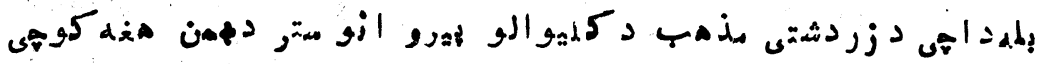

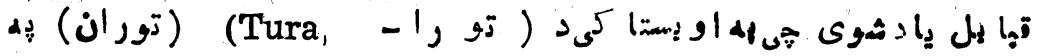

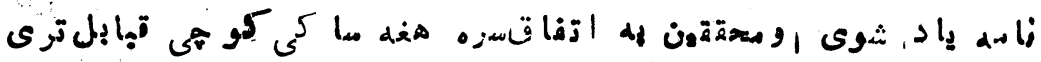

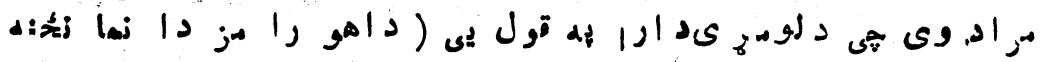

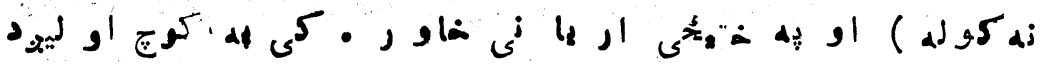

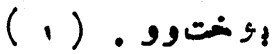

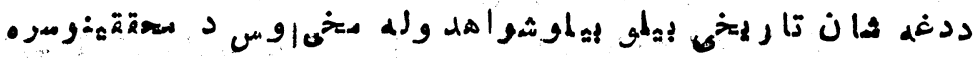

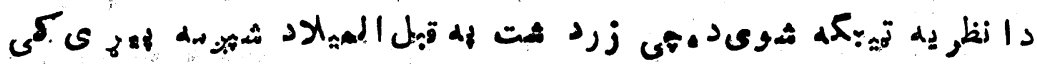

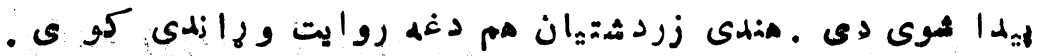

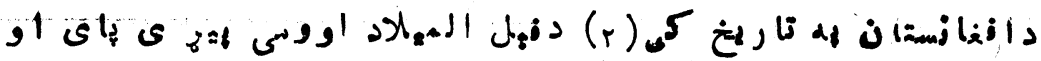

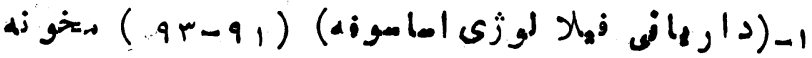

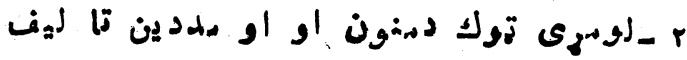




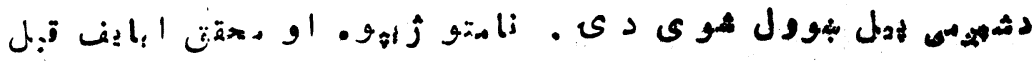

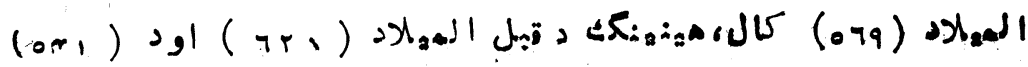

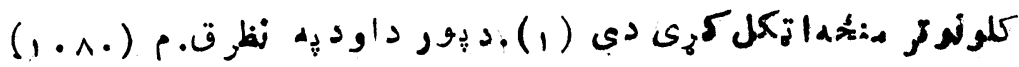

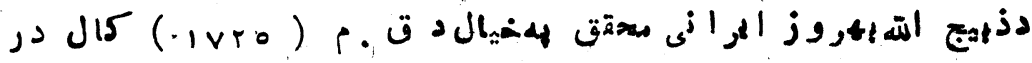

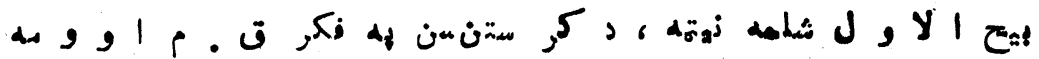

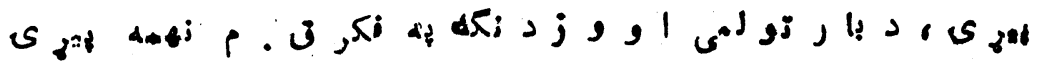

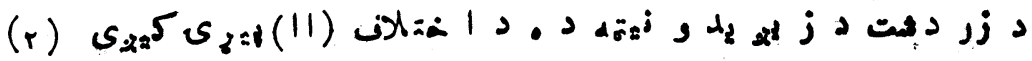

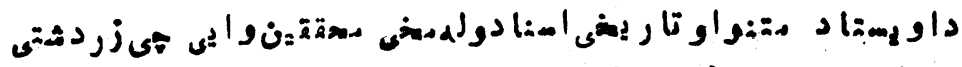

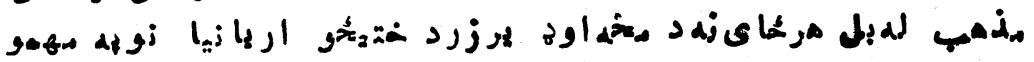

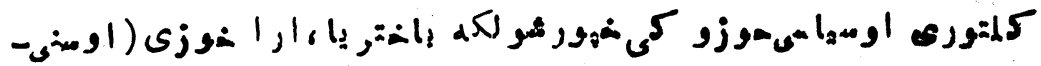

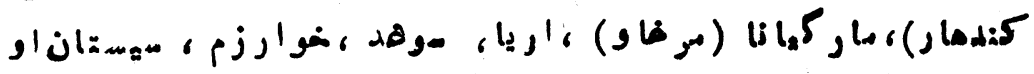

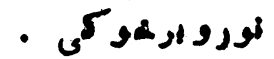

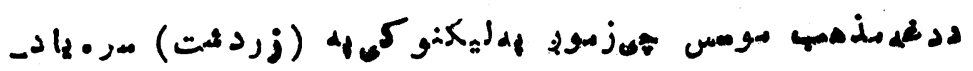

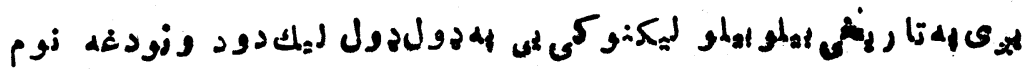

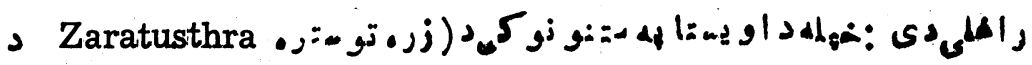

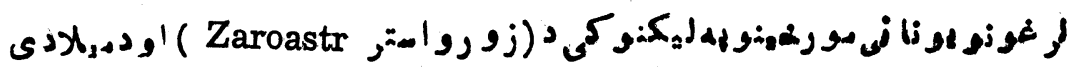

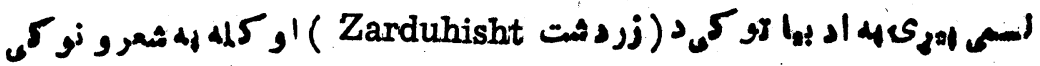

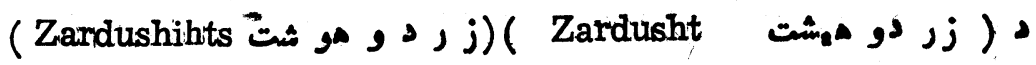

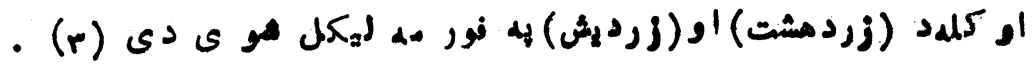

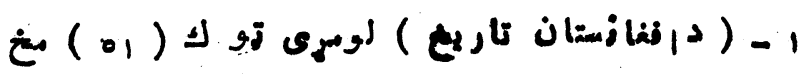

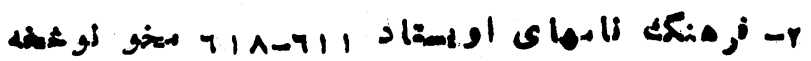

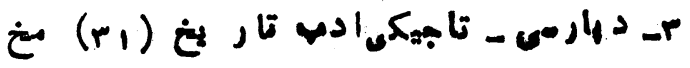




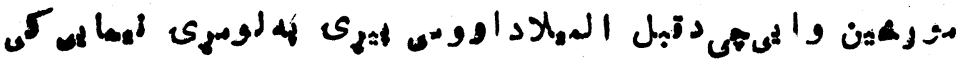

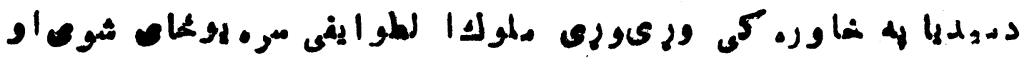

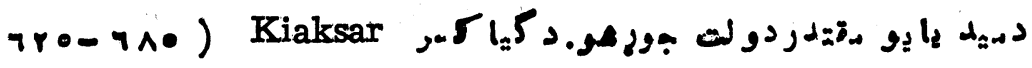

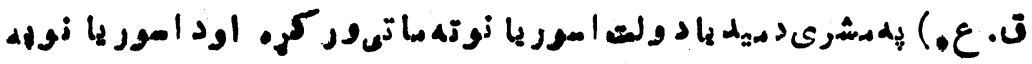

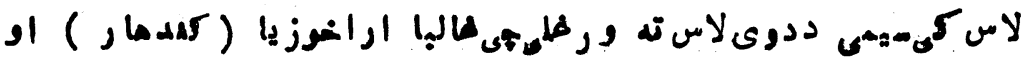

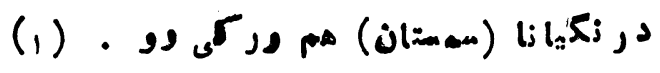

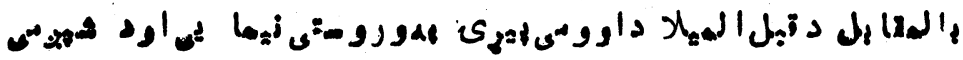

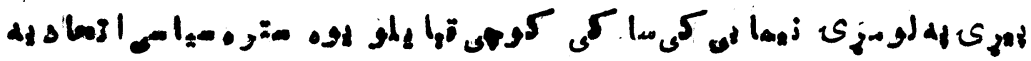

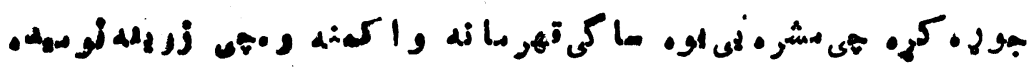

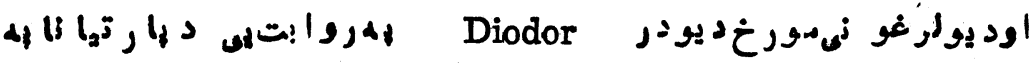

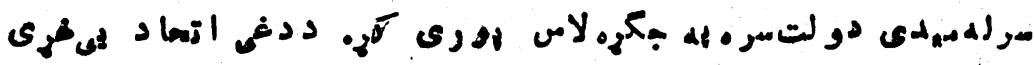

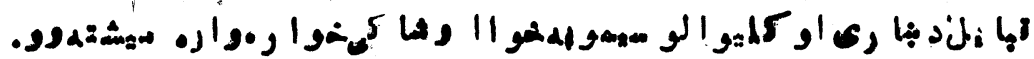

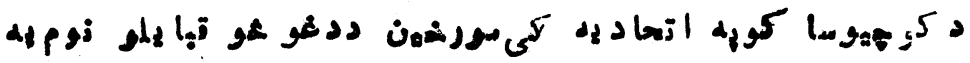

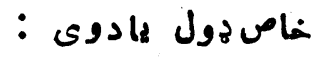

(Apasiakie ) (

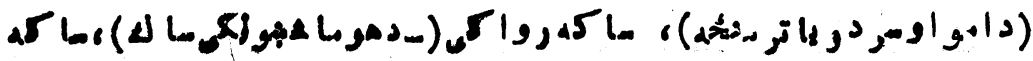

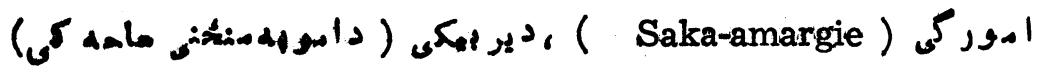

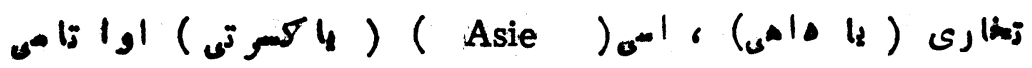
(r) . (Attasie)

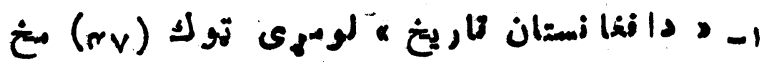

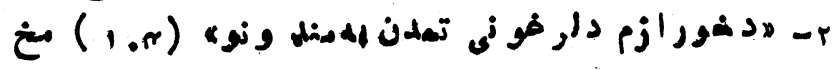


-..

$-{ }^{v} \wedge-$

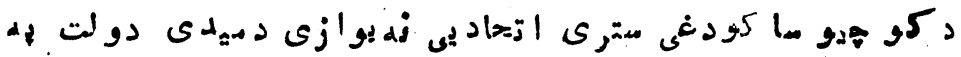

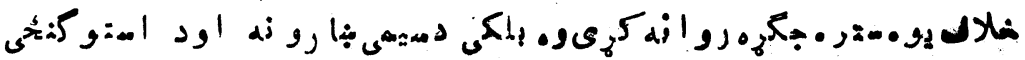

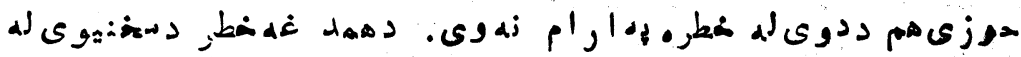

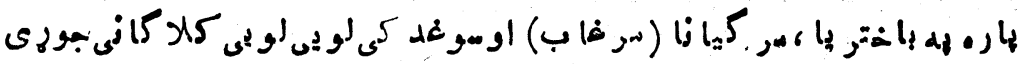

موى .

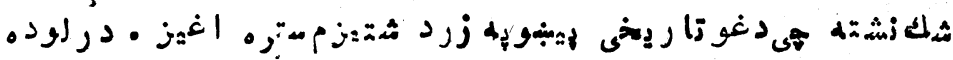

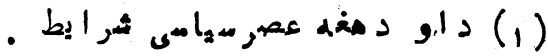

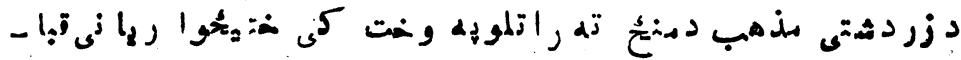

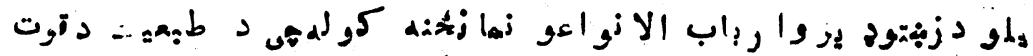

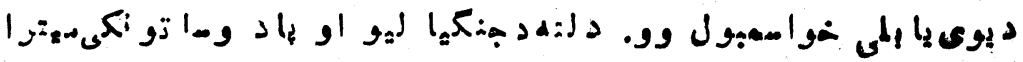
(Mitra)

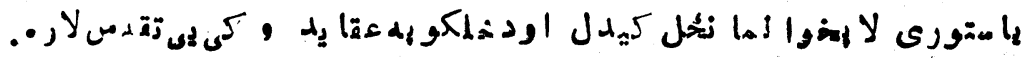

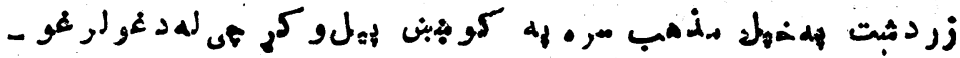

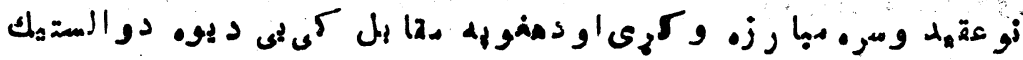

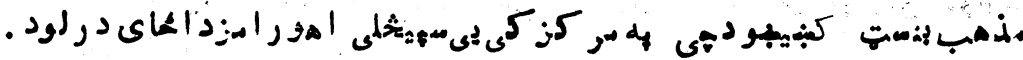

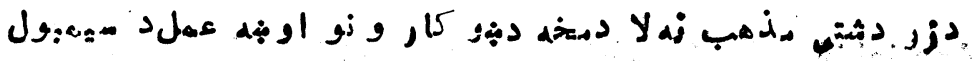
ك

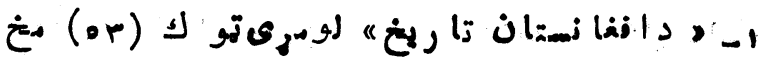

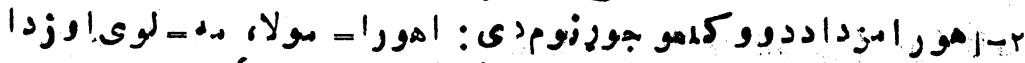

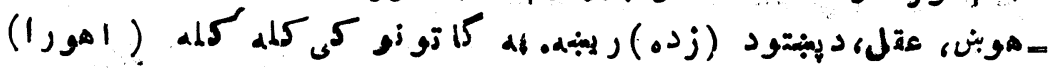

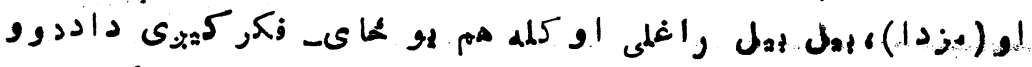

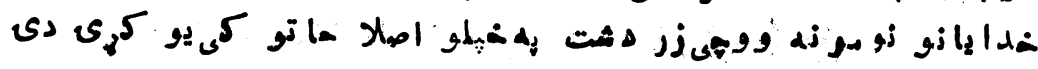

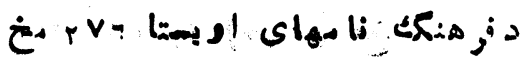


- v9-

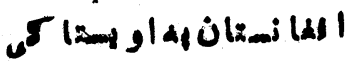

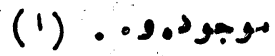

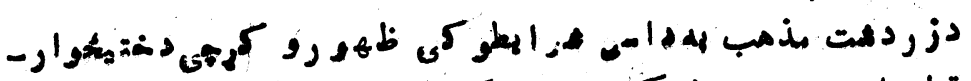

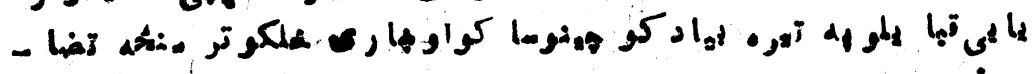

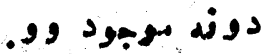

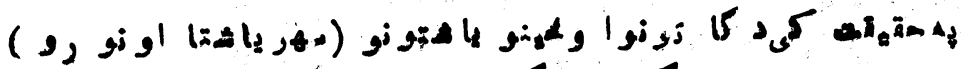

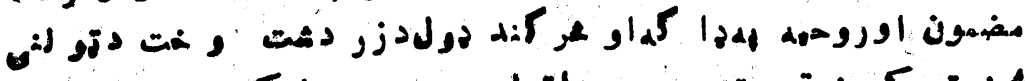

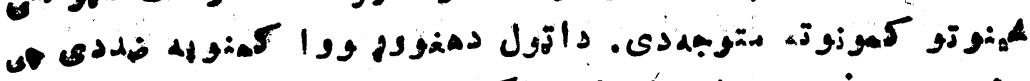

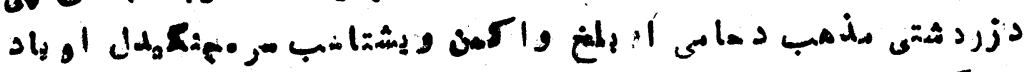

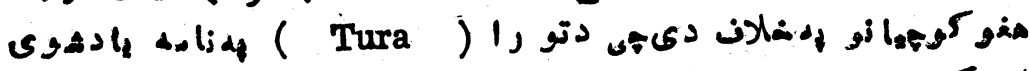

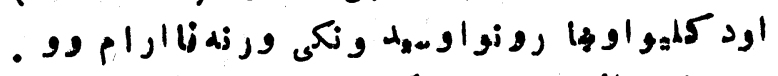

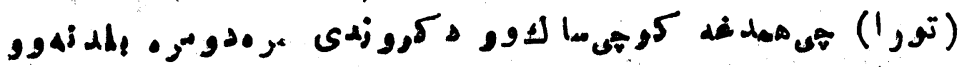

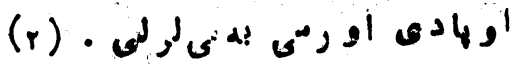

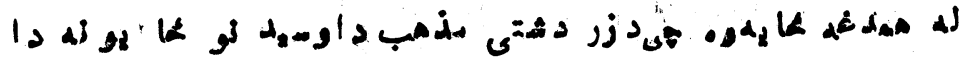

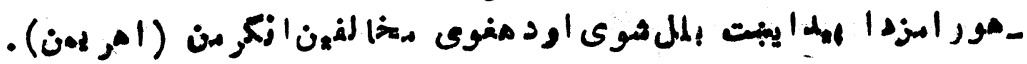

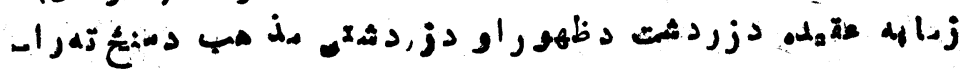

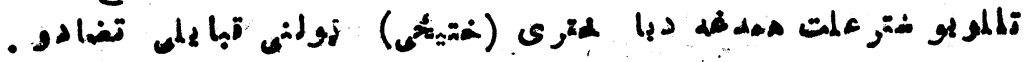

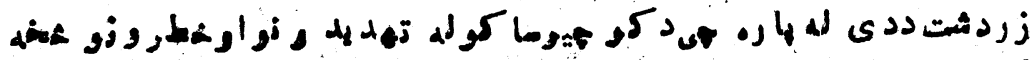

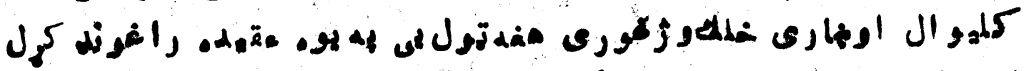

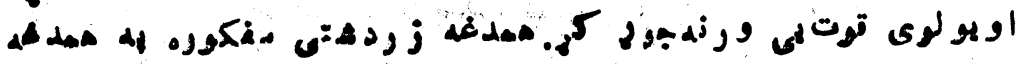

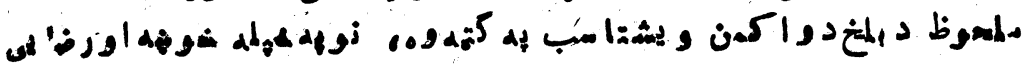

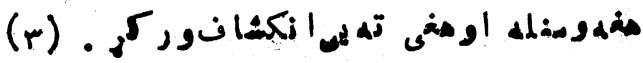

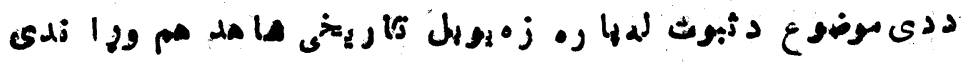

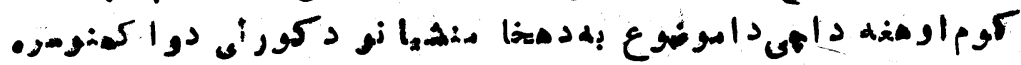

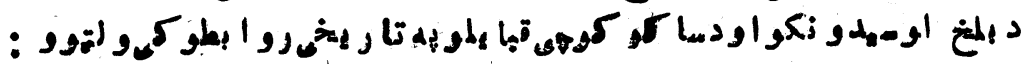

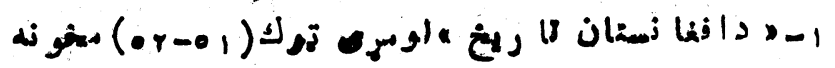

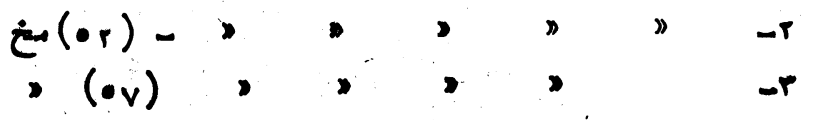


- . ol s

$\stackrel{\wedge}{\wedge-}$

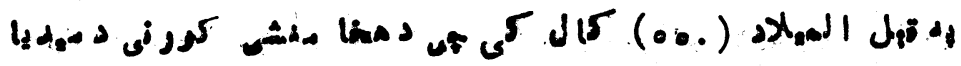

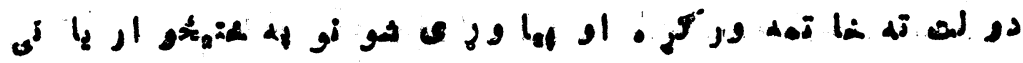

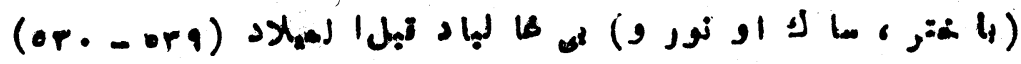

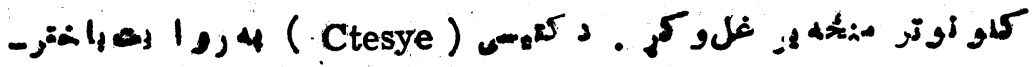

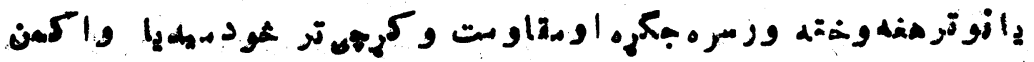
ا

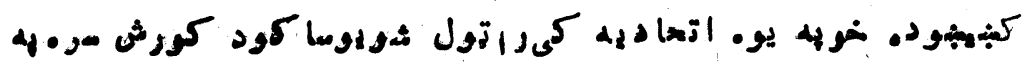

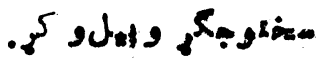

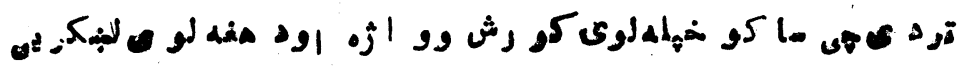

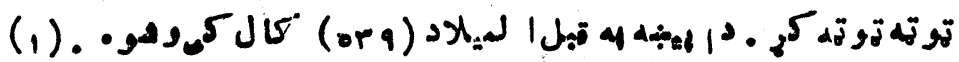

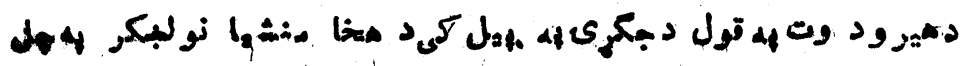

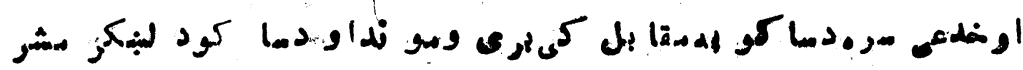

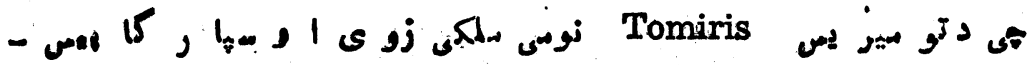
(Spargapis)

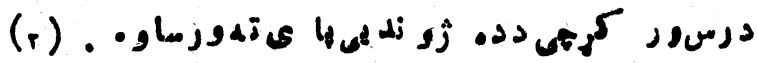

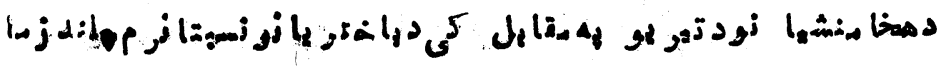

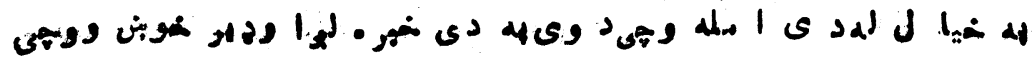

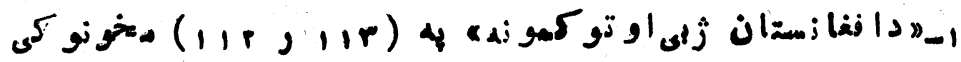

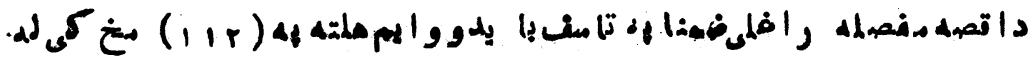

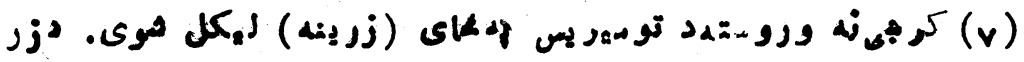

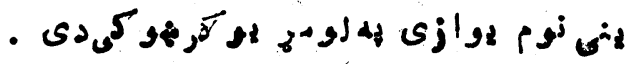

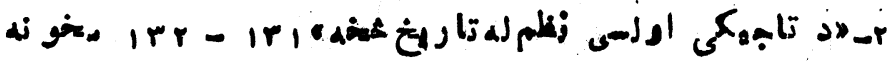


$-\Lambda_{1}-$

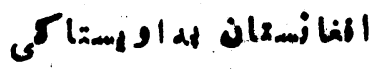

هوب:

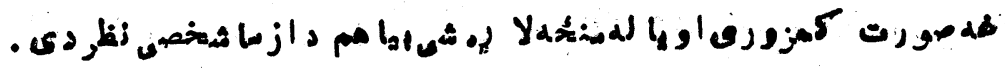

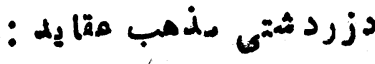

دزردثةتى مذهب دعis

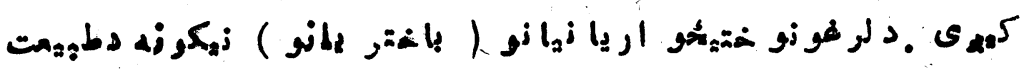

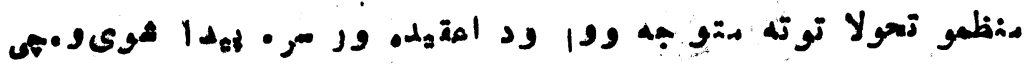

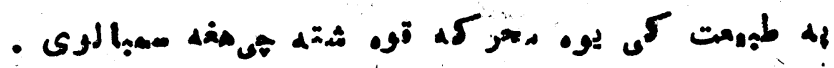

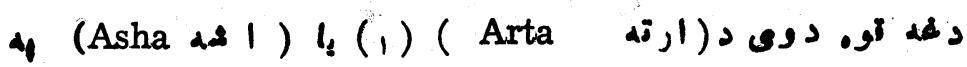
- Als alli

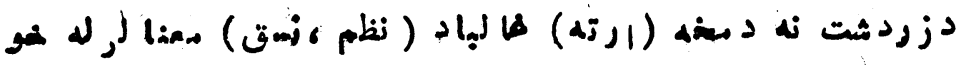

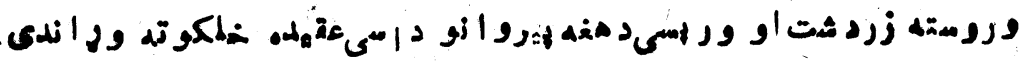

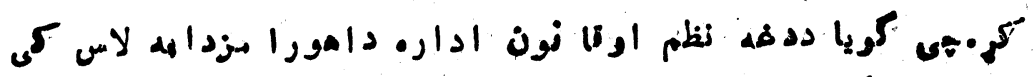

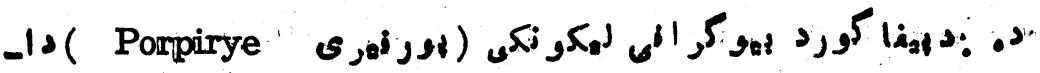

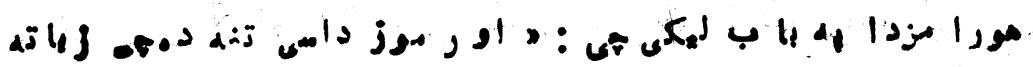

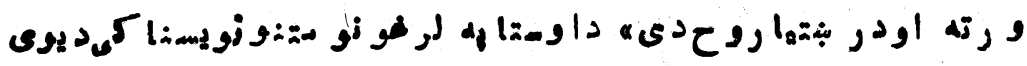

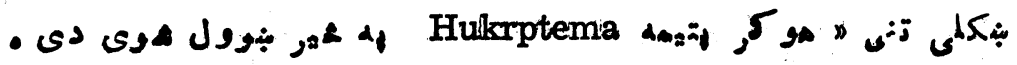

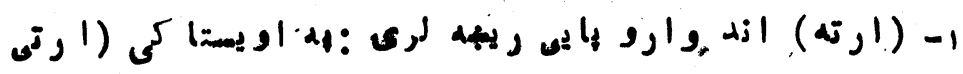

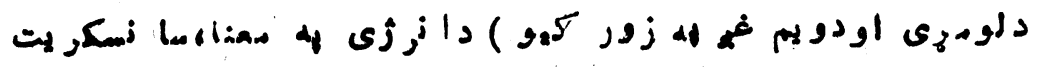

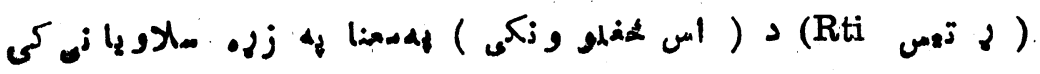

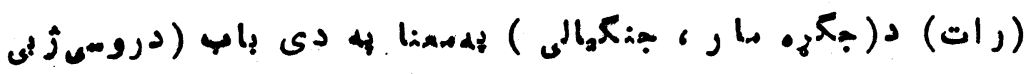

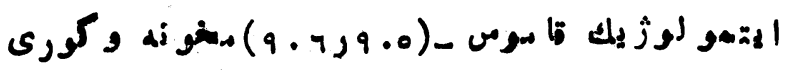




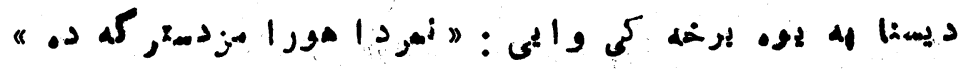

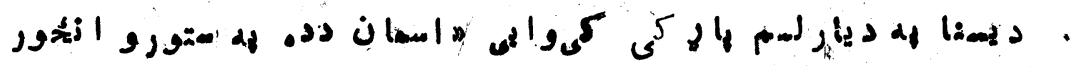

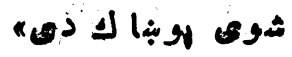

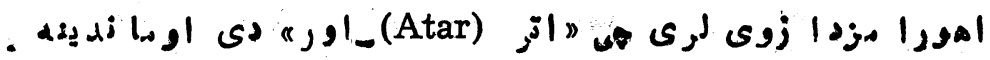

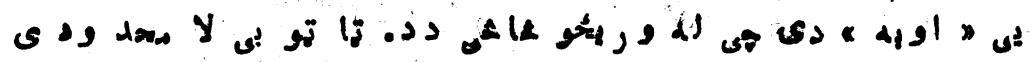
(1) (1)

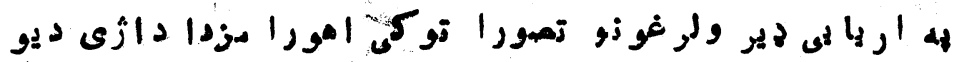

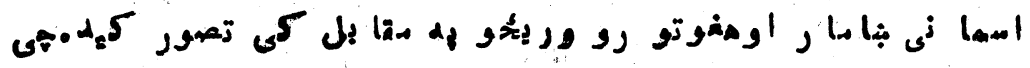

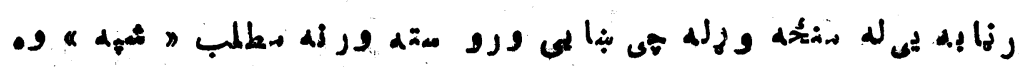

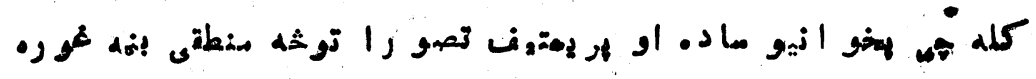

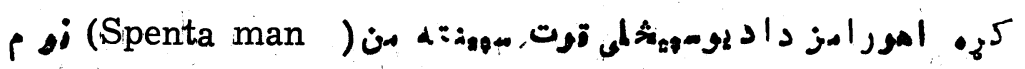

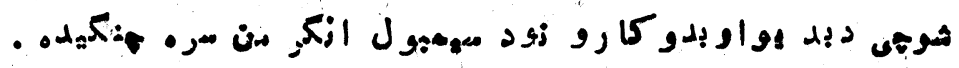

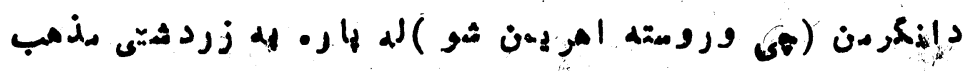

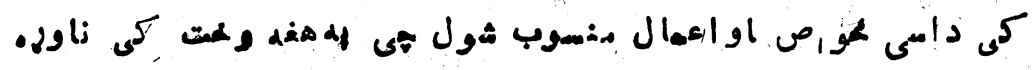

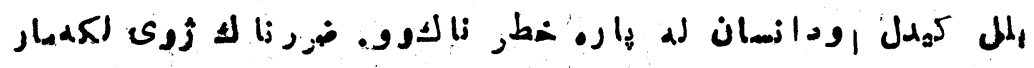

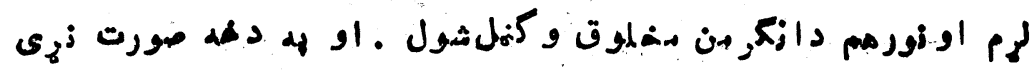

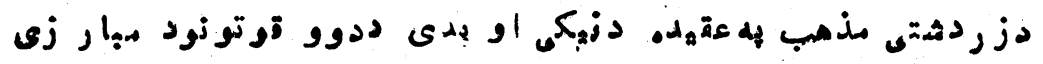

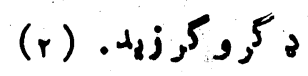

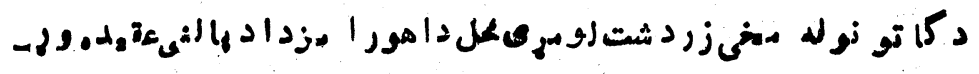

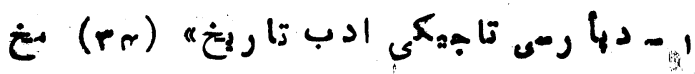

$$
\begin{aligned}
& \left(r_{0}\right)>0, r
\end{aligned}
$$




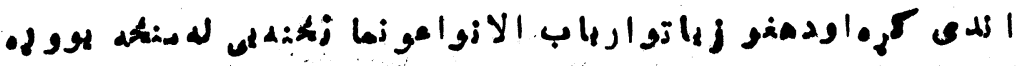
-

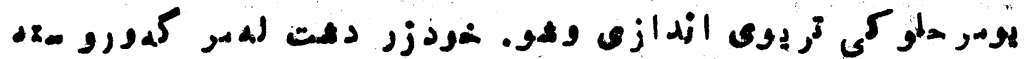

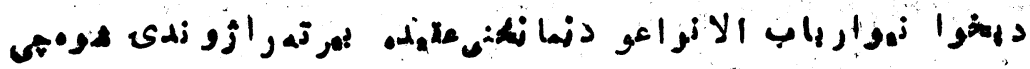

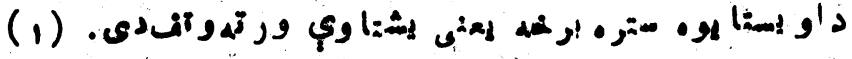

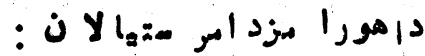

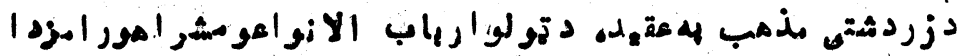

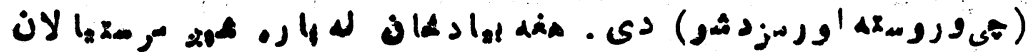
(v) $15 d_{a} i j$-Amesha spenta

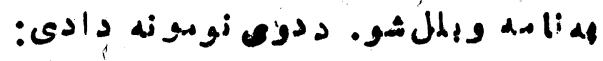

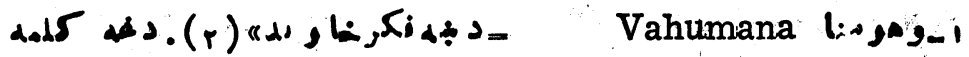
ور

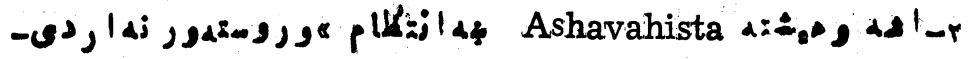

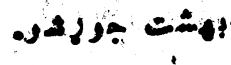

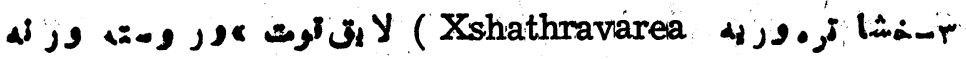
osinger gat

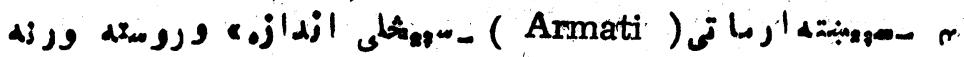

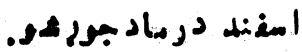

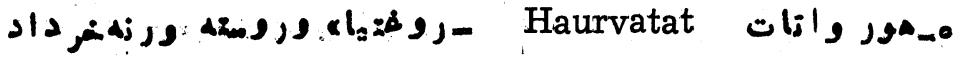

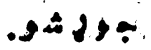

$$
\text { ا- }
$$

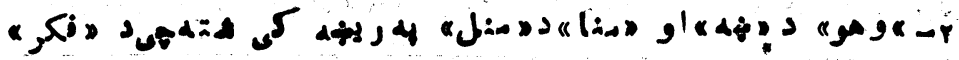




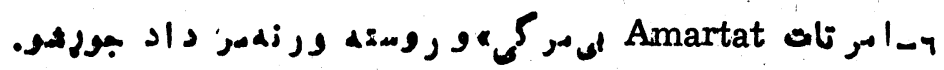

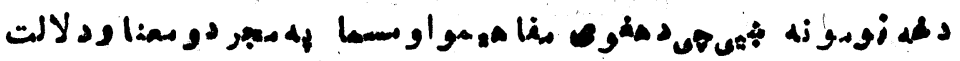

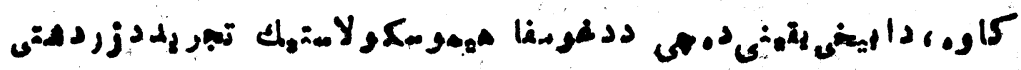

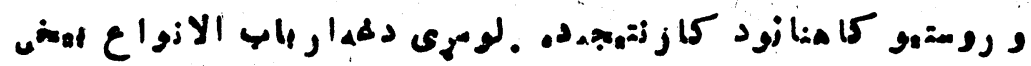

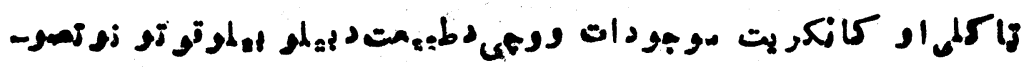

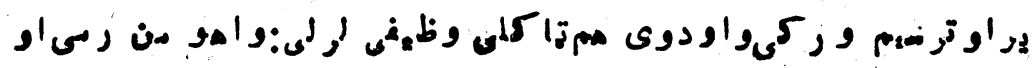

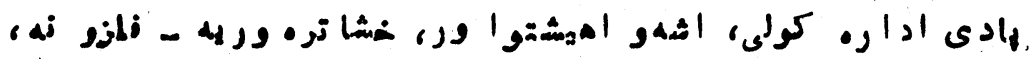

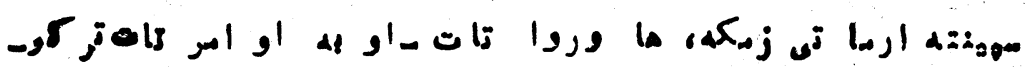
دع ادار. كول.

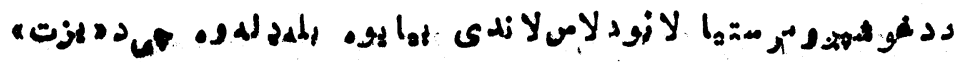

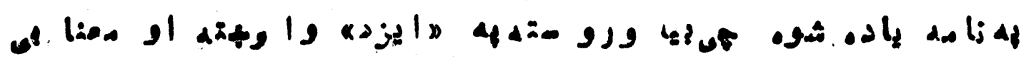

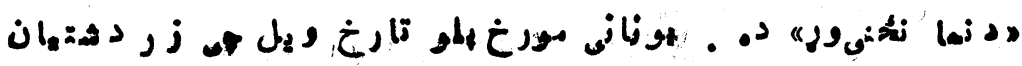

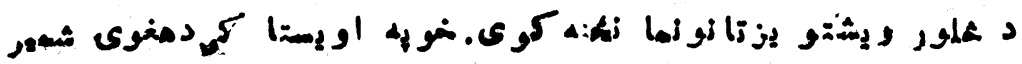

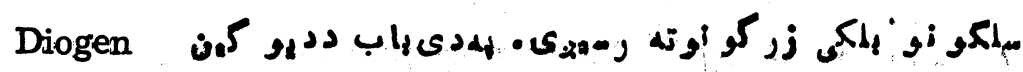

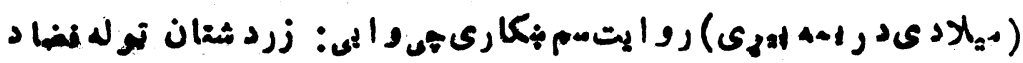

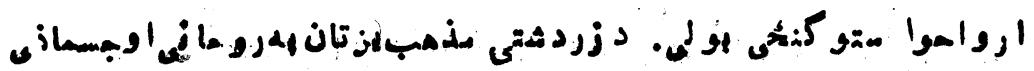

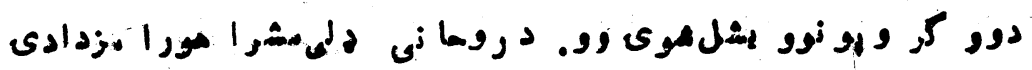

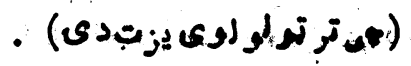

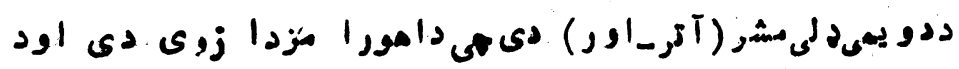

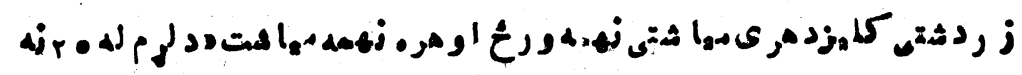

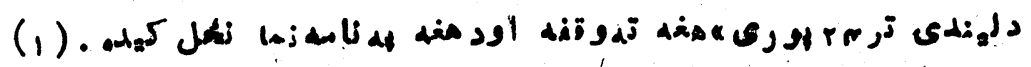

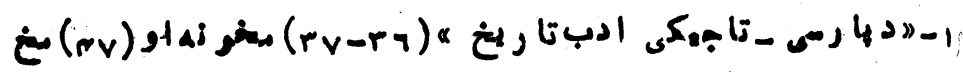


-AO-

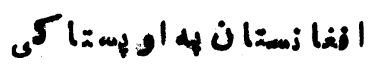

(Atur is Atar

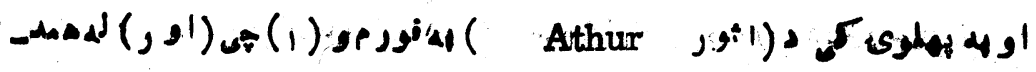

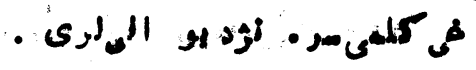
مiم

: J

والهو نر يان ( Vahufryan ) .

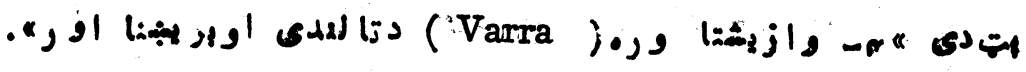

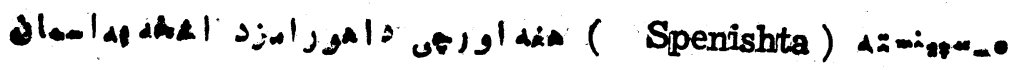

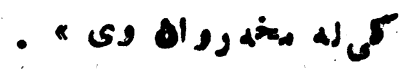

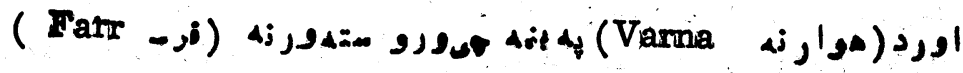

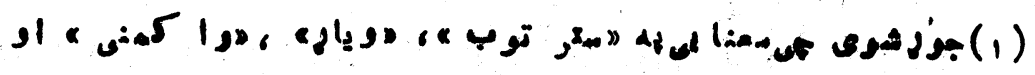

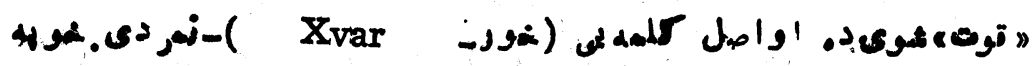

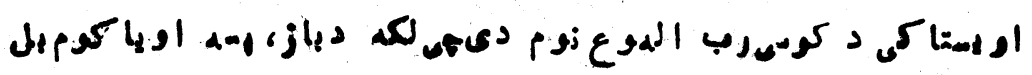

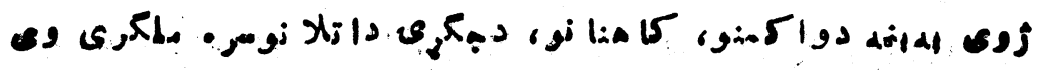

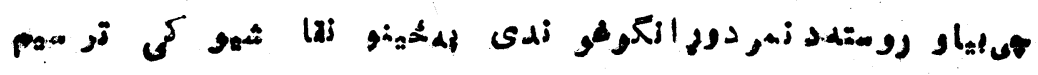
(r) : (s)

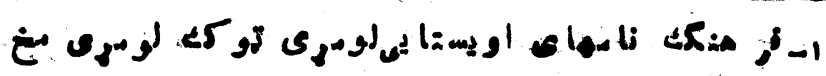

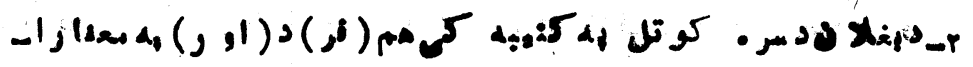
-

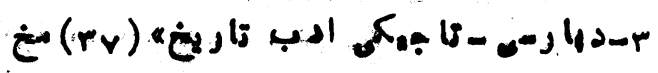




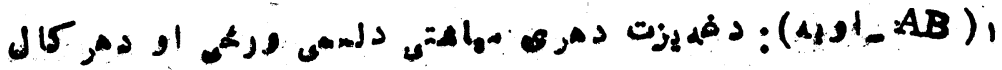

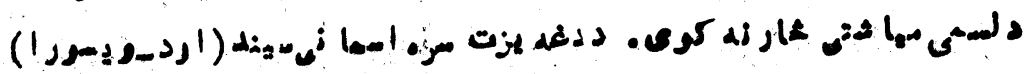
(Ardvisura)

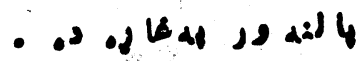

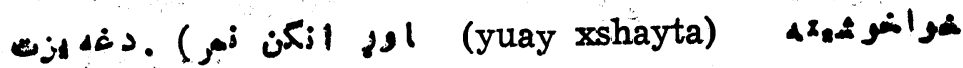

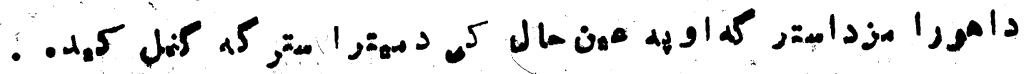

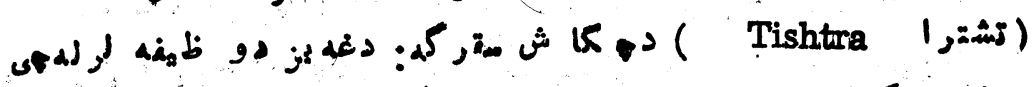

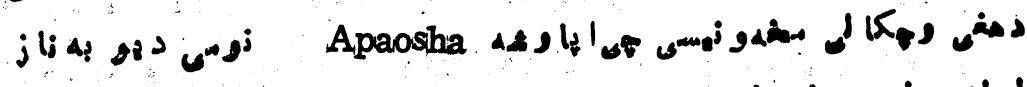

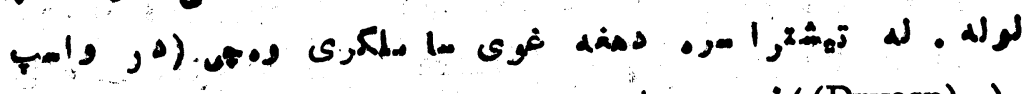

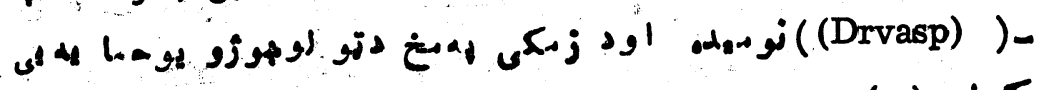
(1) (1) مو (a)

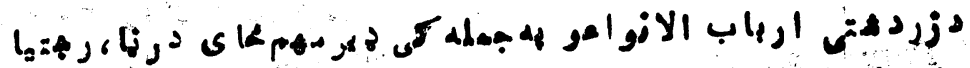

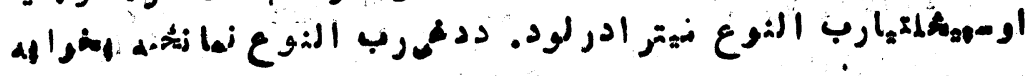

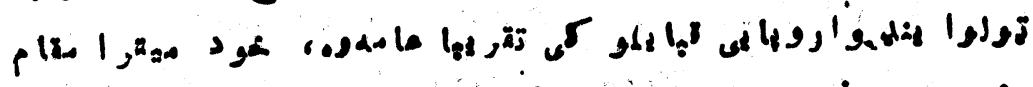

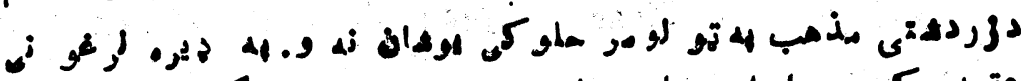

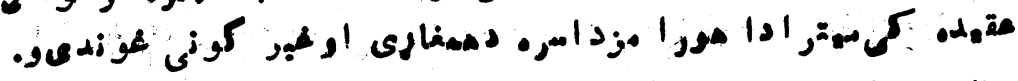

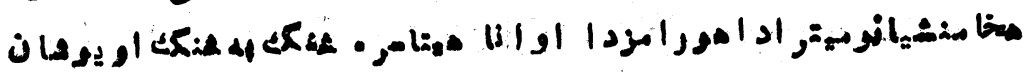

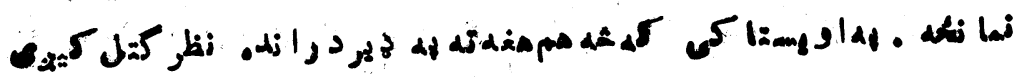

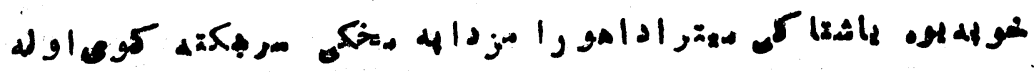

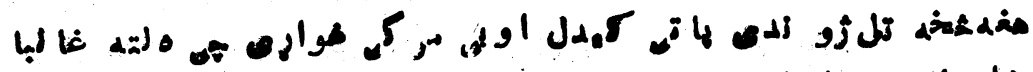

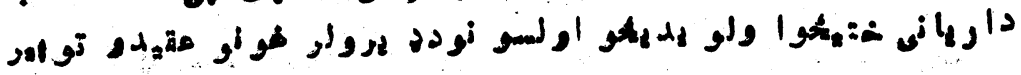
- 
$-\lambda^{\wedge} v_{-}$

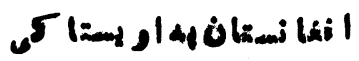

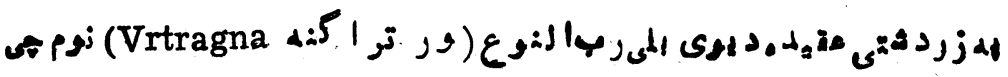

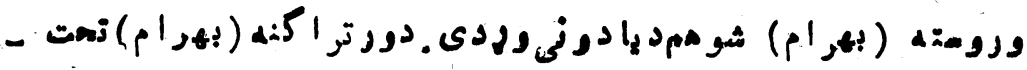

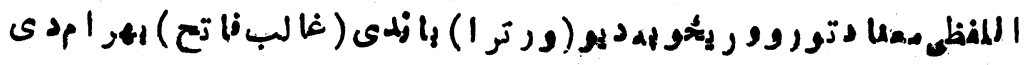

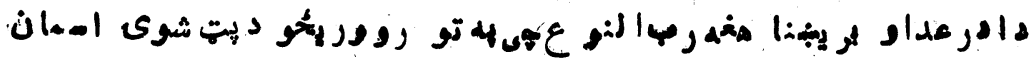

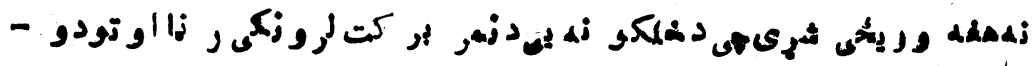

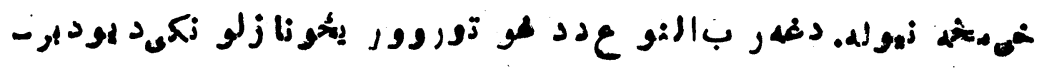

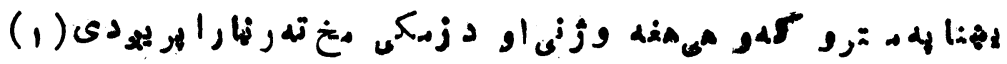

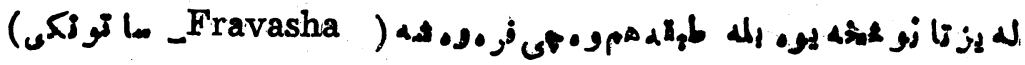

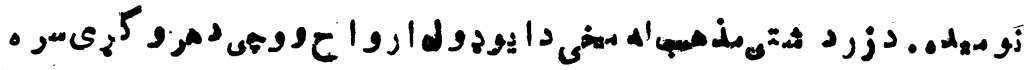

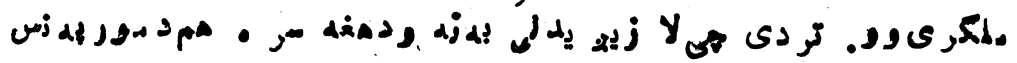

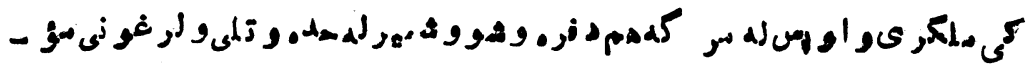

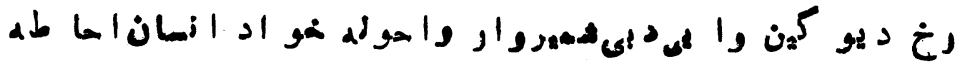

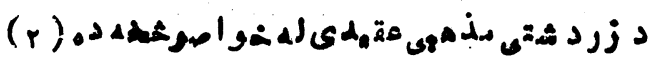

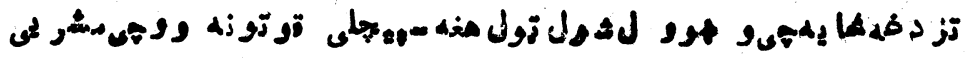

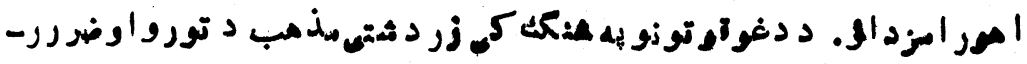

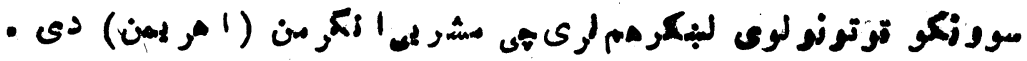

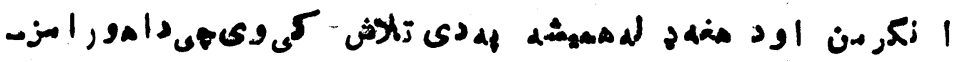

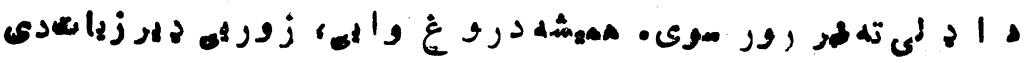

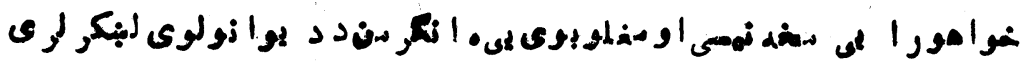

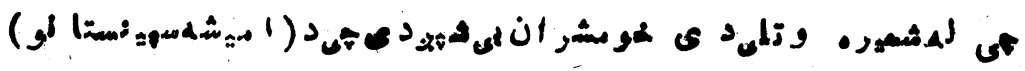
:

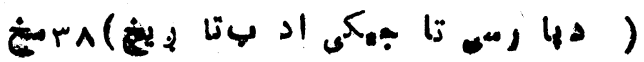




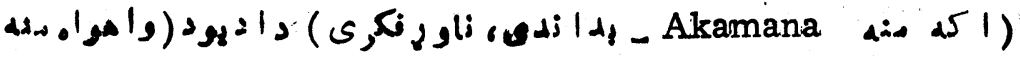

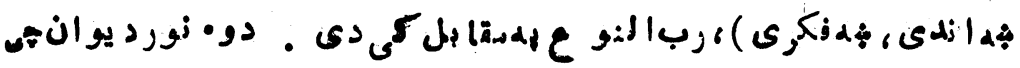

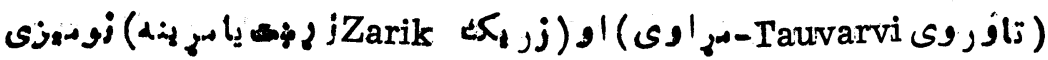

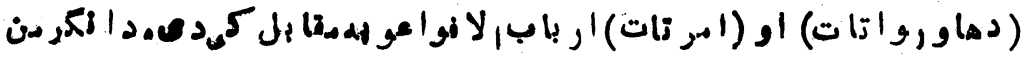

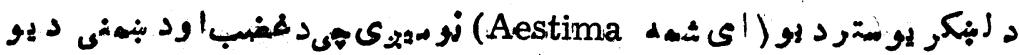

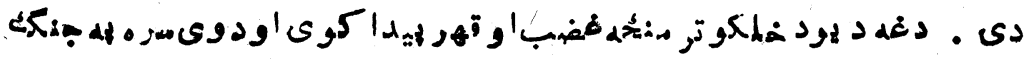

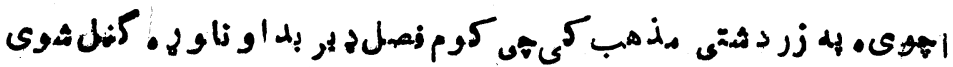

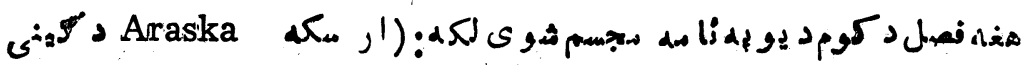

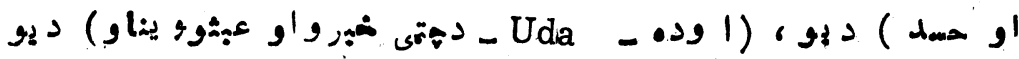

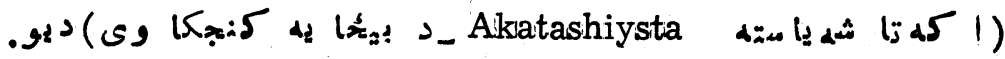

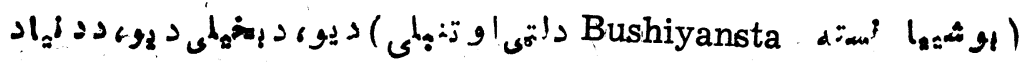

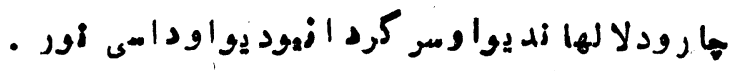

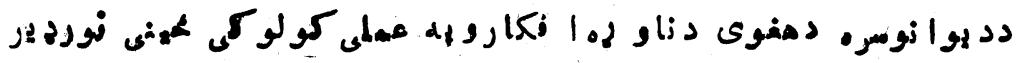

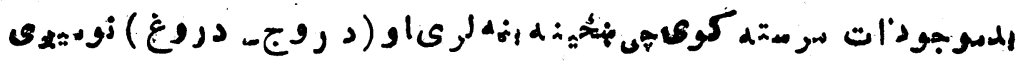

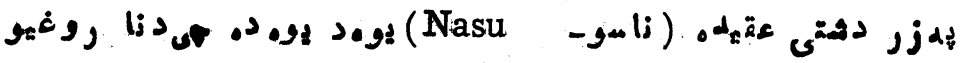

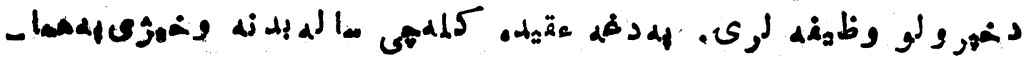

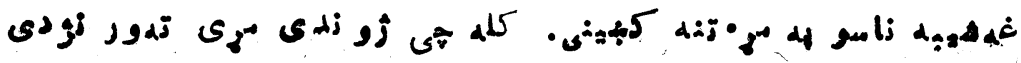

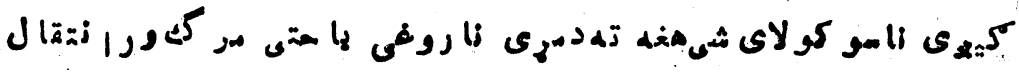

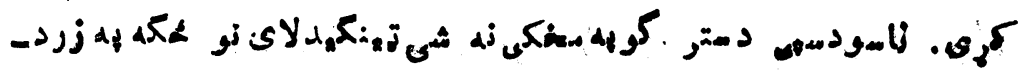

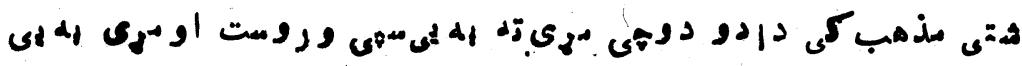

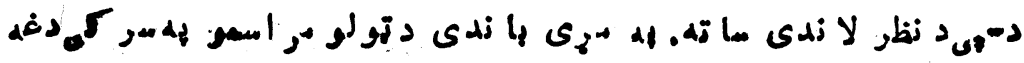

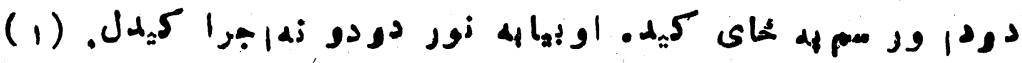

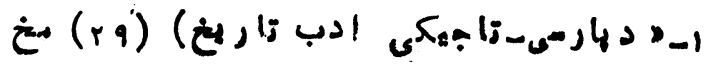




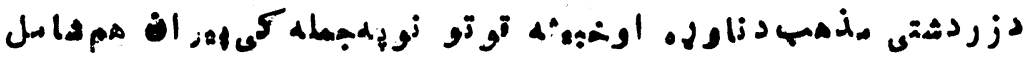

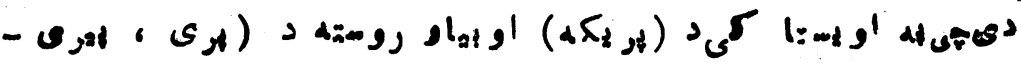
( Peri,Pari

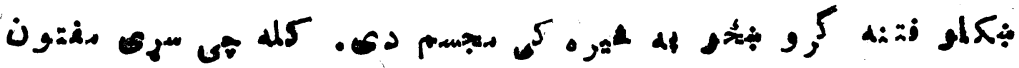

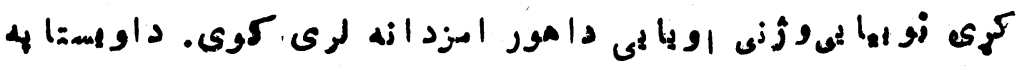

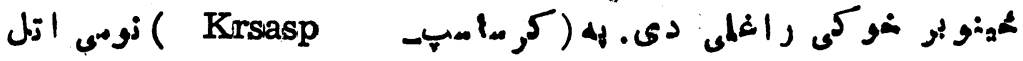

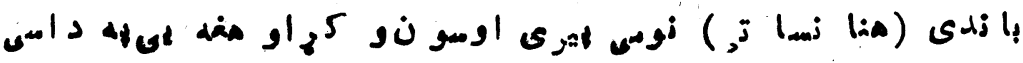

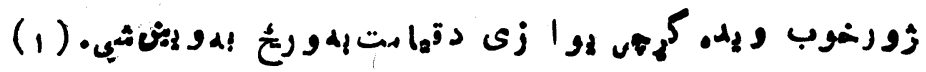

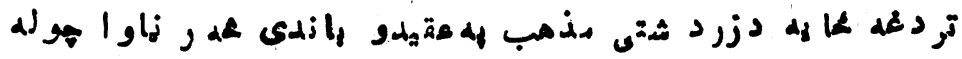

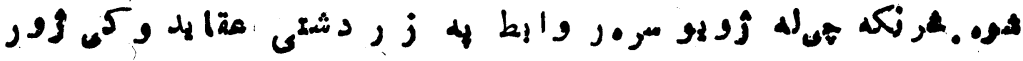

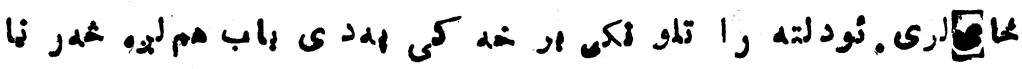
- 


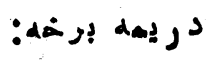

دزو يوسره دزر دشتيزم رابطهد(البرز)

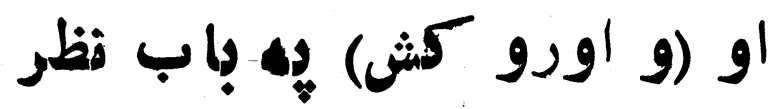

دا

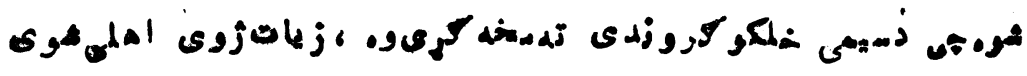

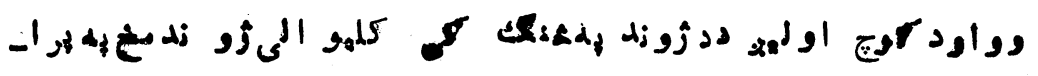

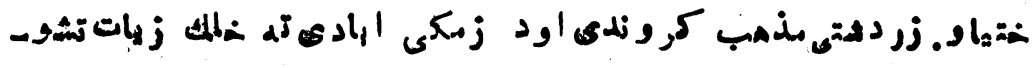

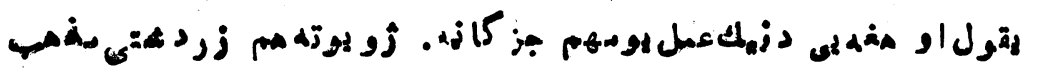

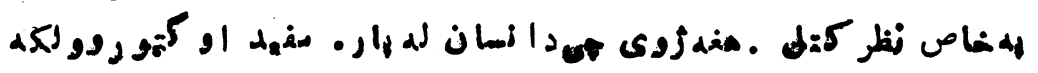

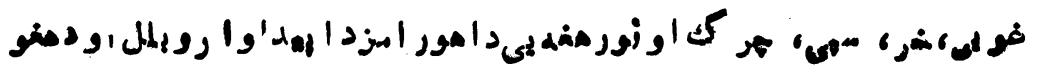

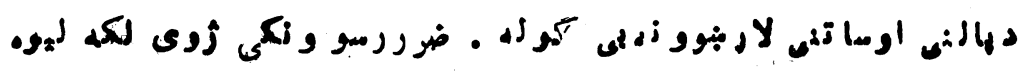

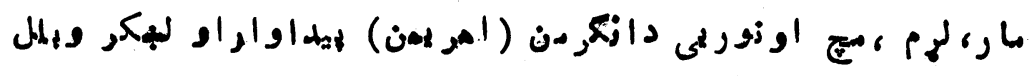

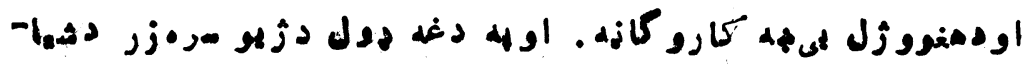

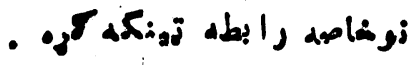


$-11-$

كا

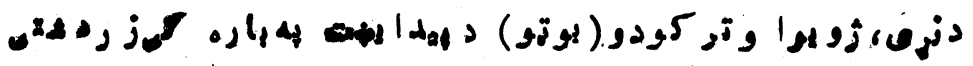

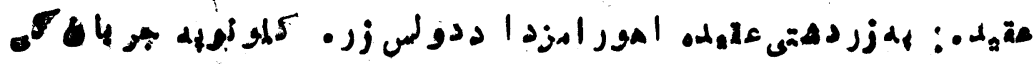

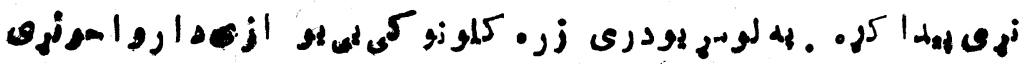

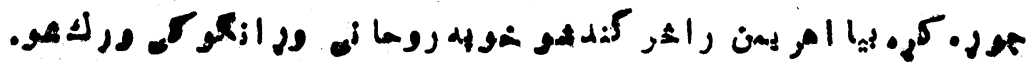

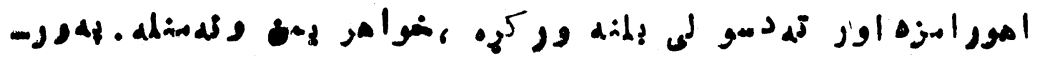

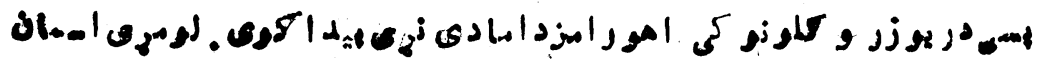

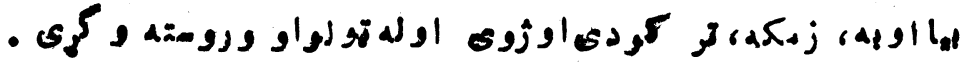

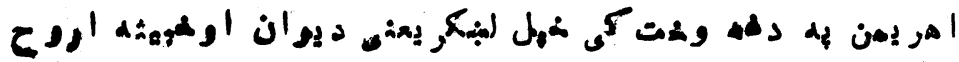

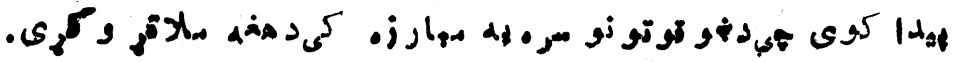

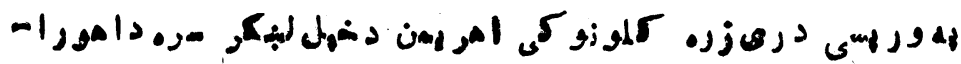

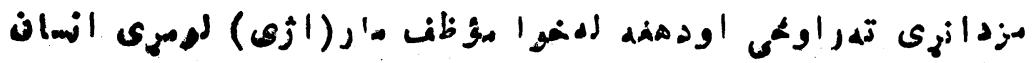

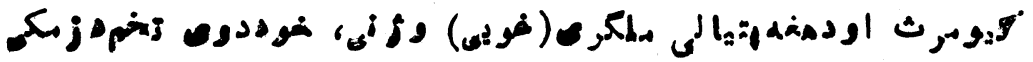

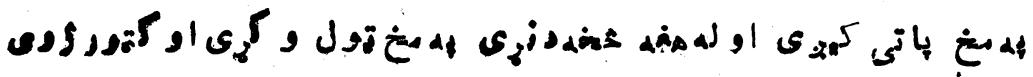

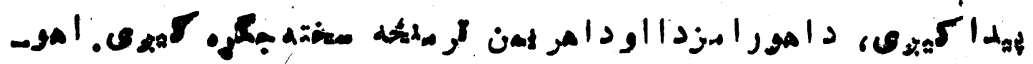

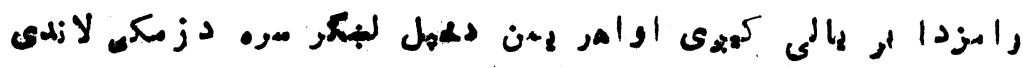

تهر و ته تمبنتيى

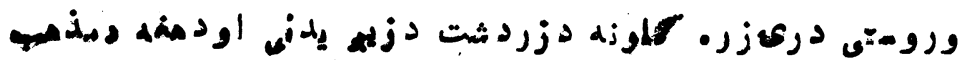

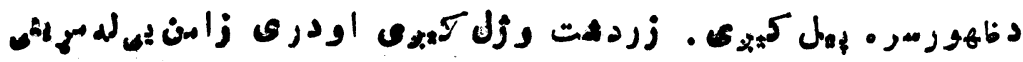

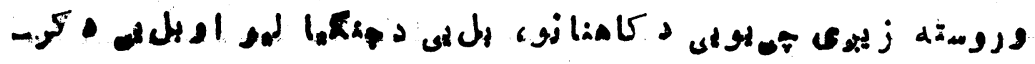
و

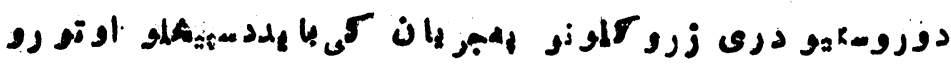

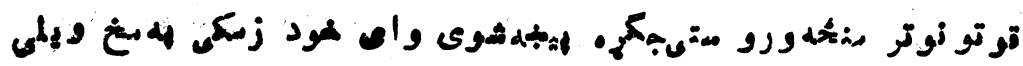


-. Slos

$-9 \dot{\gamma}=$

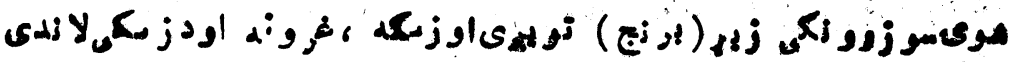

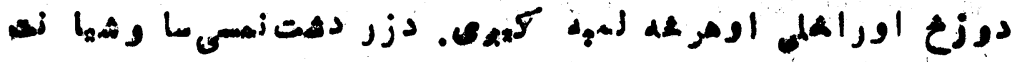
Sa Sashyant

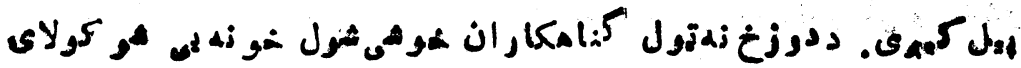
خ 1) Cinvat -

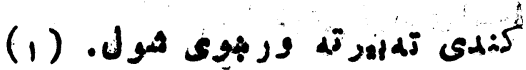

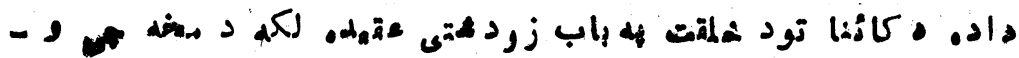

- dis

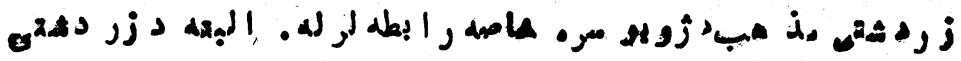

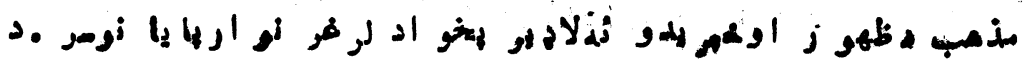

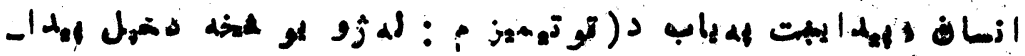

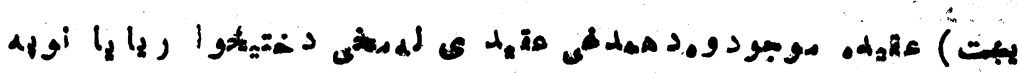

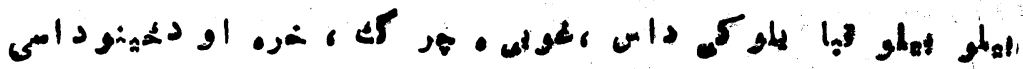

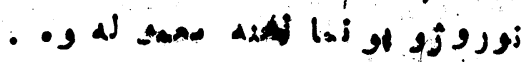

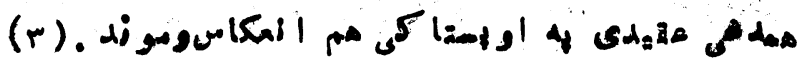

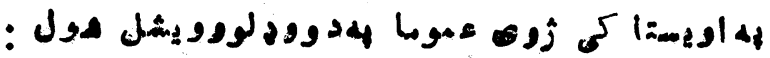

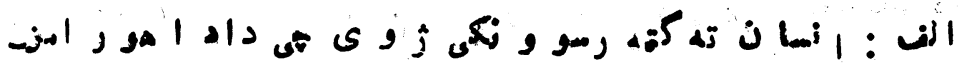

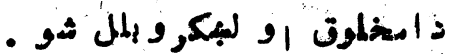

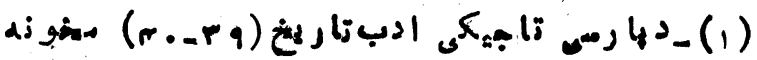

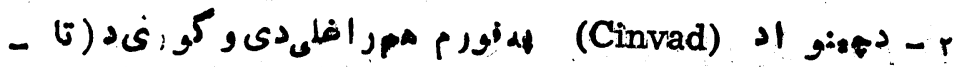

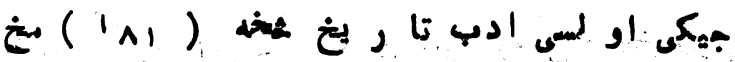

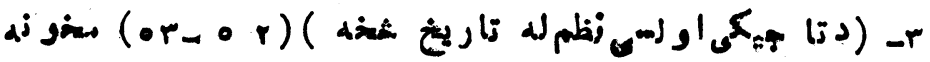




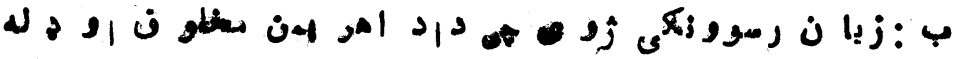

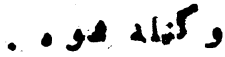

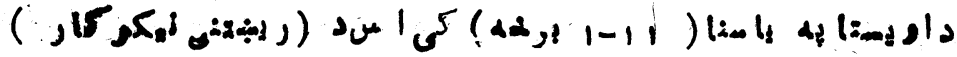

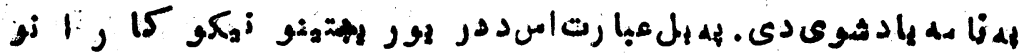

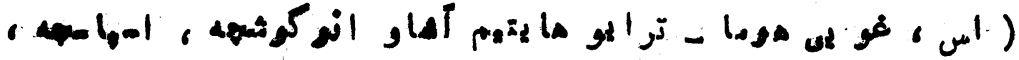

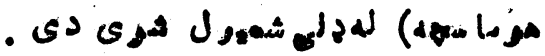

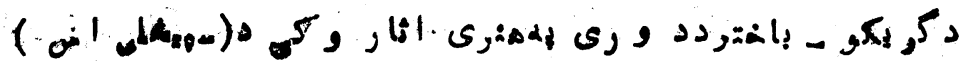

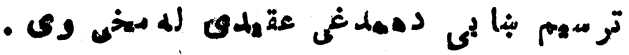

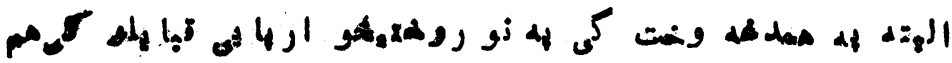

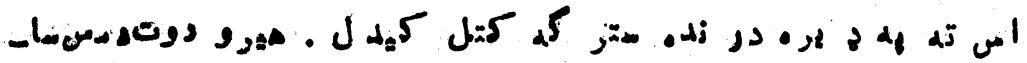

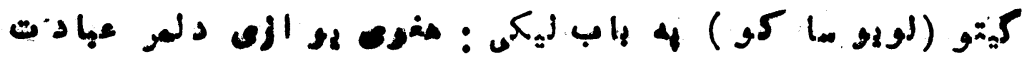

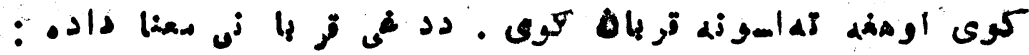

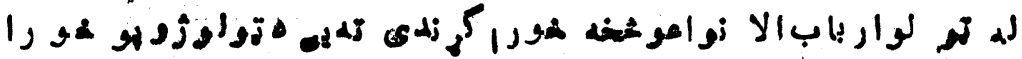

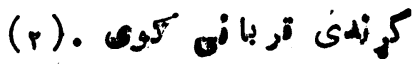

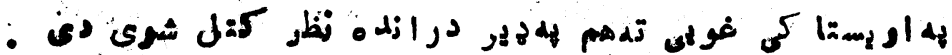

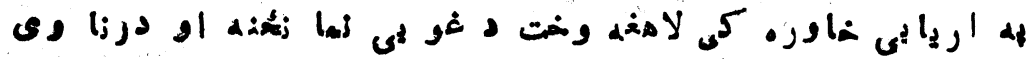

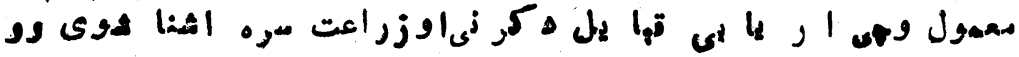

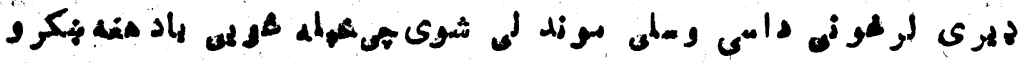

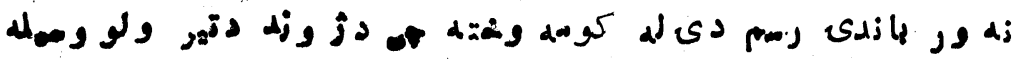

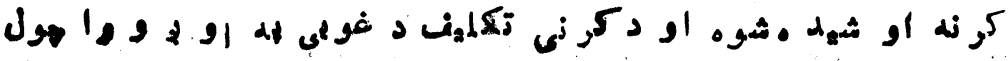

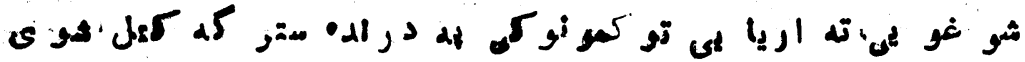

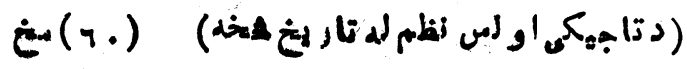




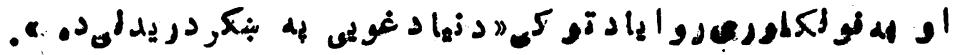

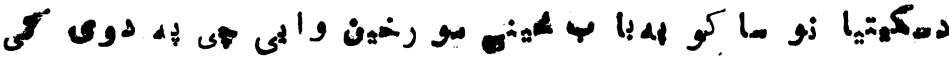

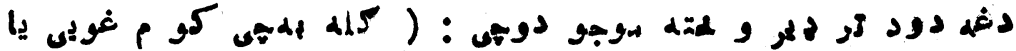

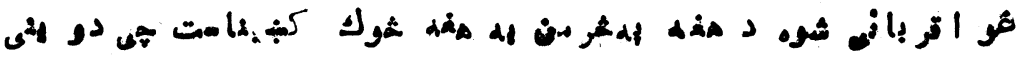

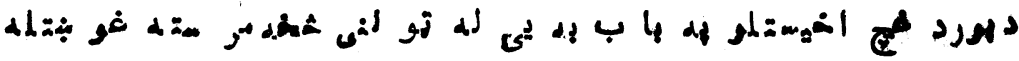

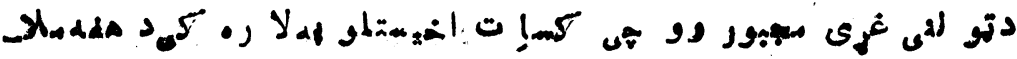

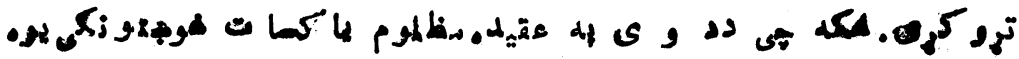

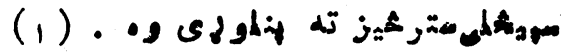

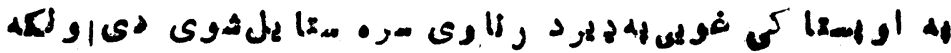

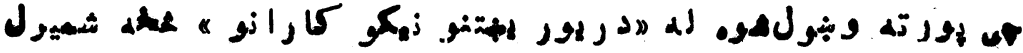

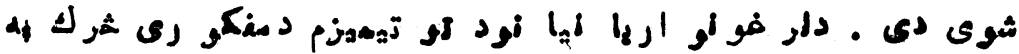

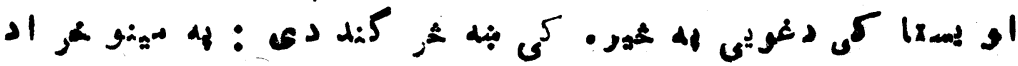
Menoixradi :

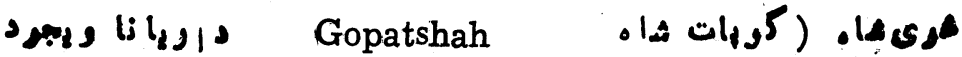

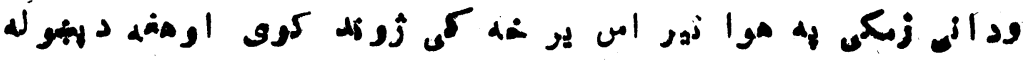

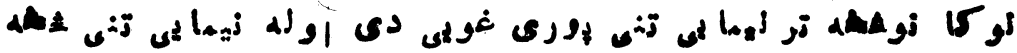

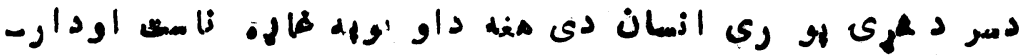

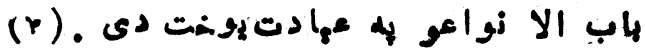

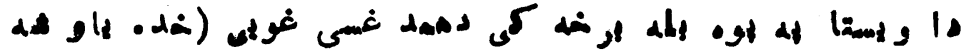
(Xadayosha

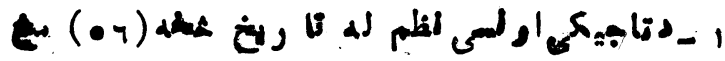

$$
\begin{aligned}
& \text { (or) } \\
& \text { ) } 1 \text {. }
\end{aligned}
$$


9

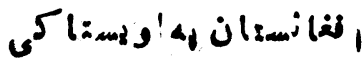

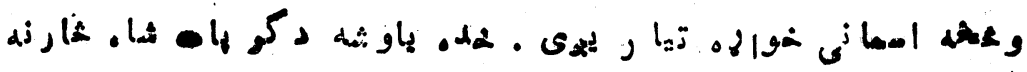

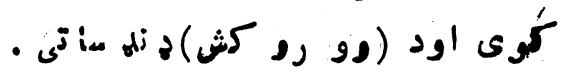

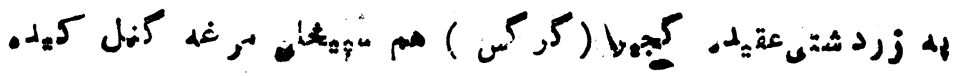

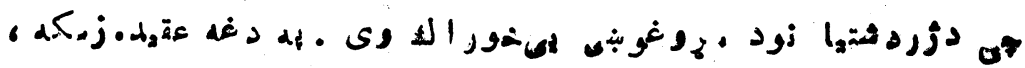

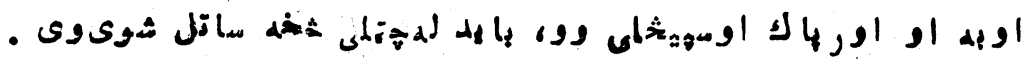

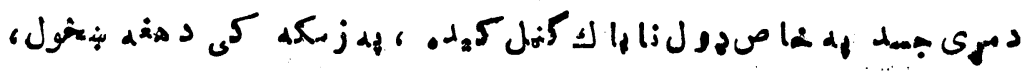

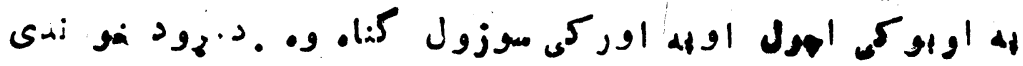

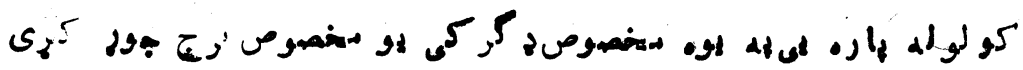

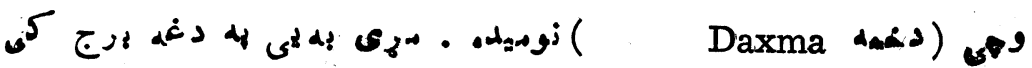

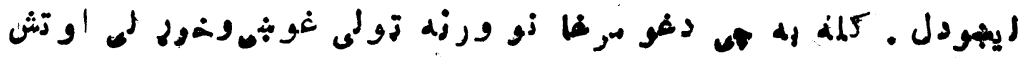

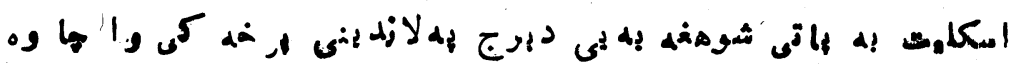

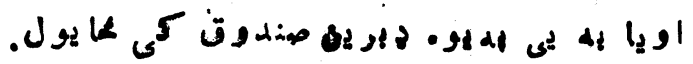

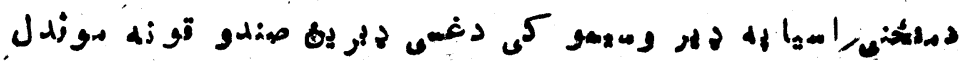

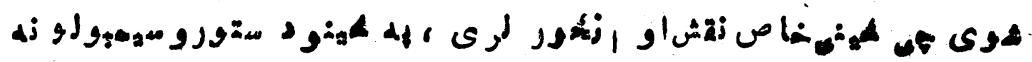

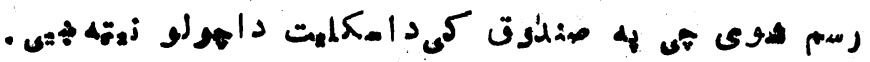

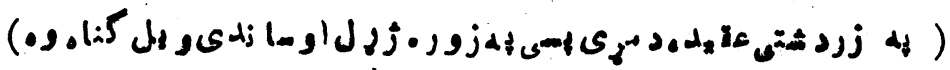

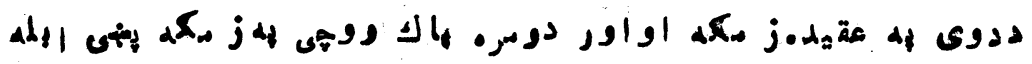

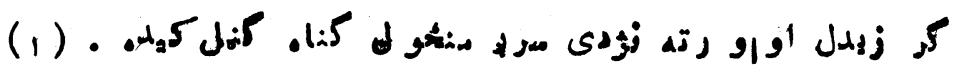

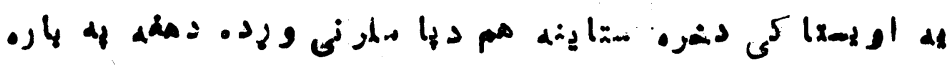

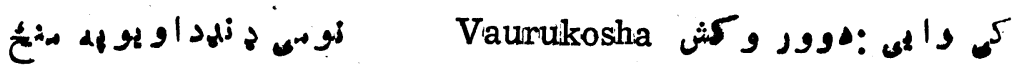

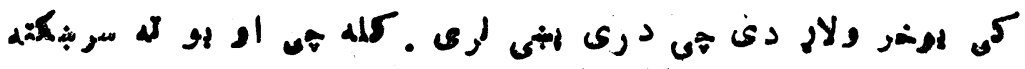

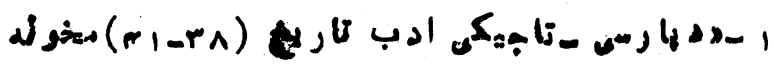


-... $\mathrm{s}^{5}$ (ans

$-97-$

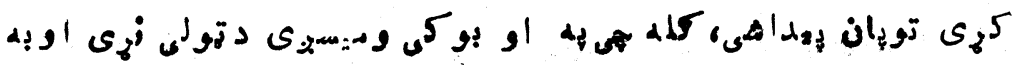

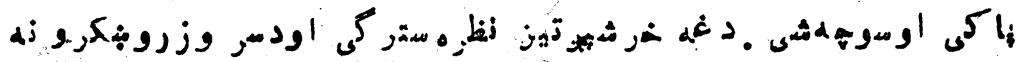

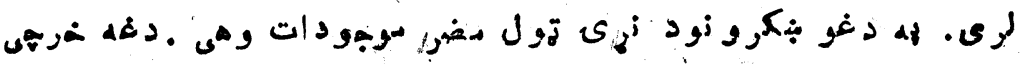

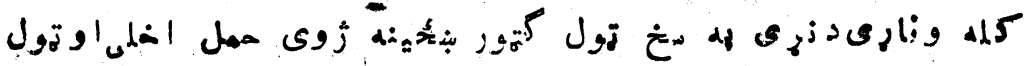

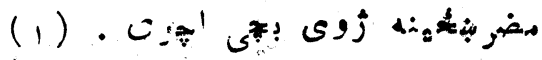

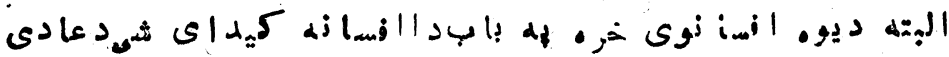

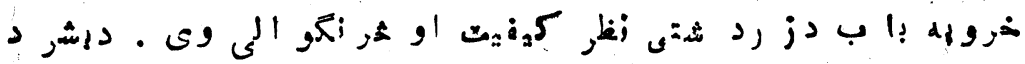

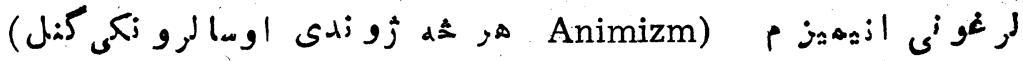

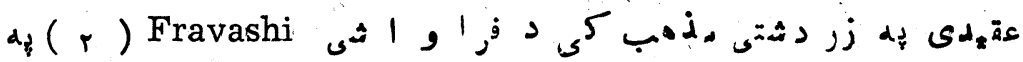

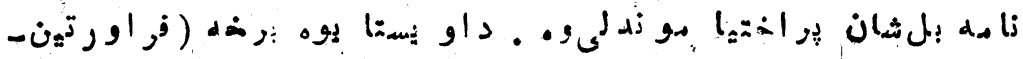

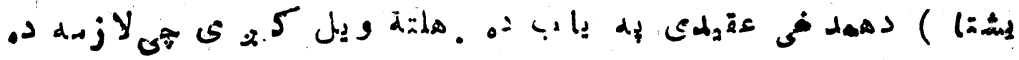

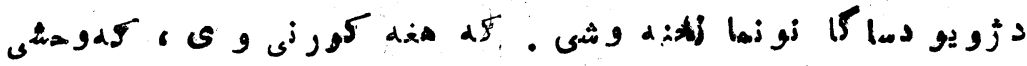

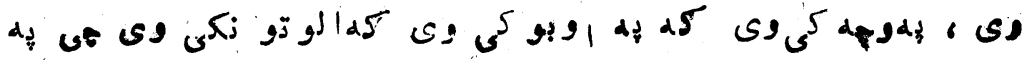

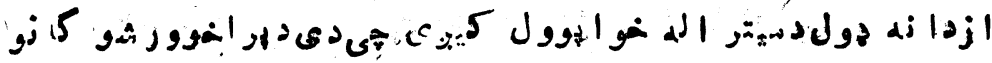

- va

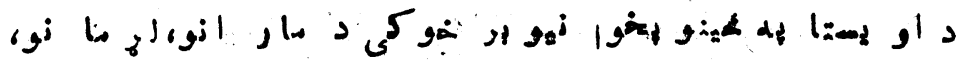

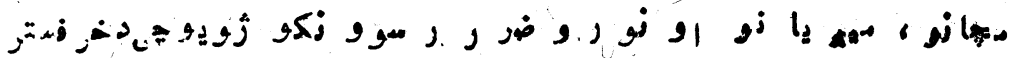

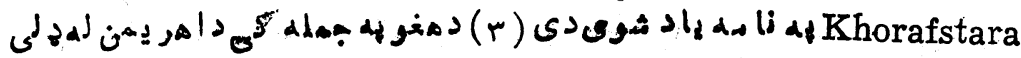

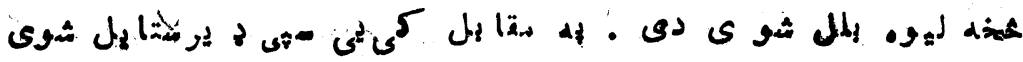

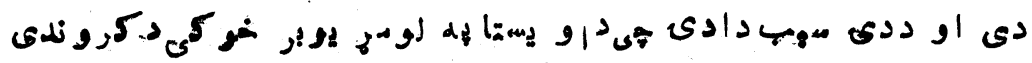

- 1

-

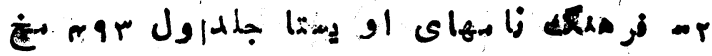


$-9 v^{*}$

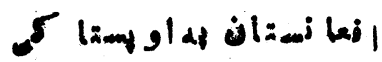

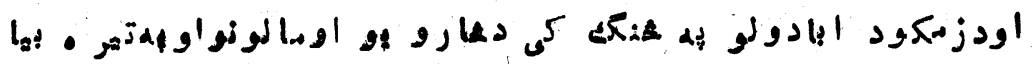

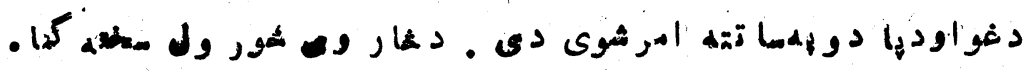

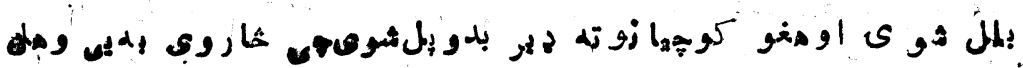

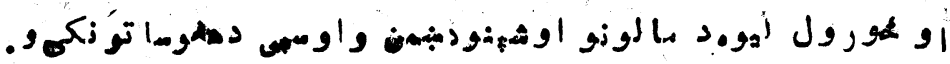

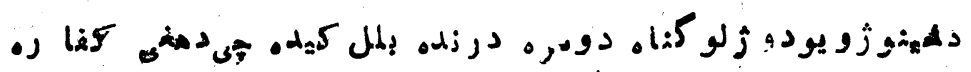

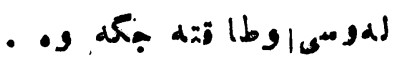

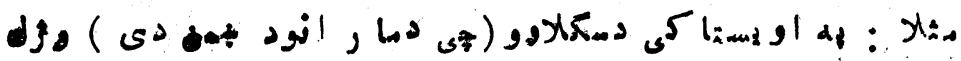

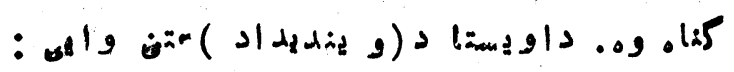

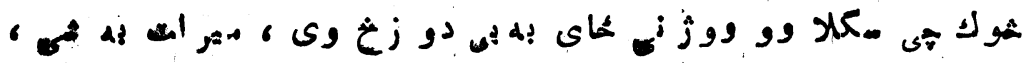

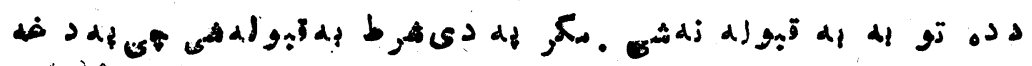

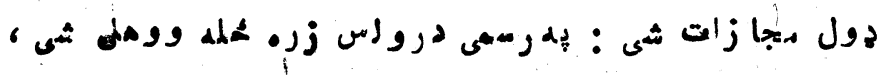

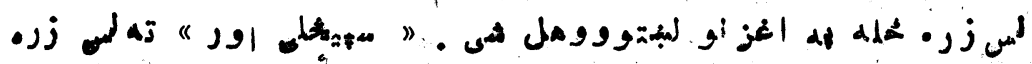

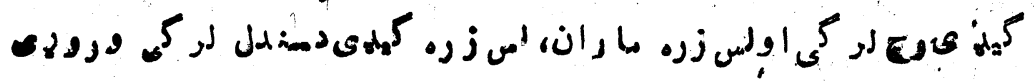

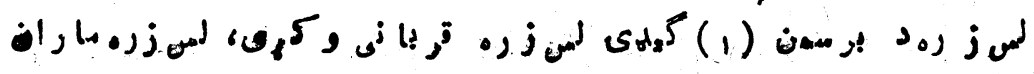

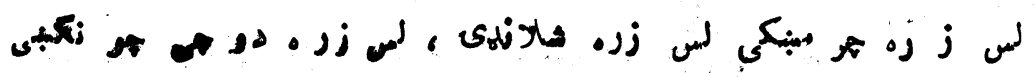

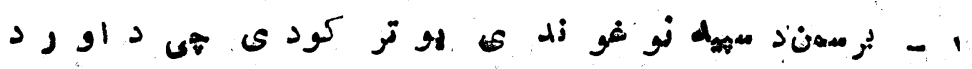

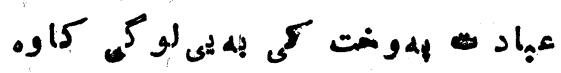

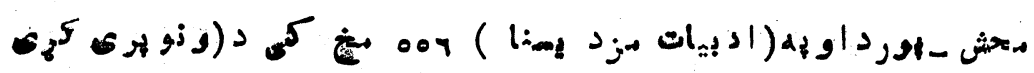

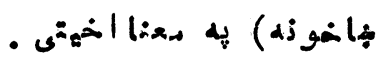

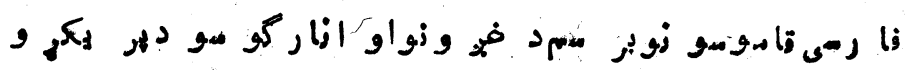

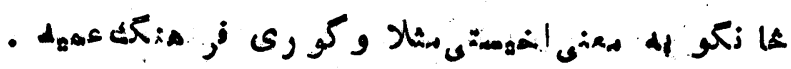




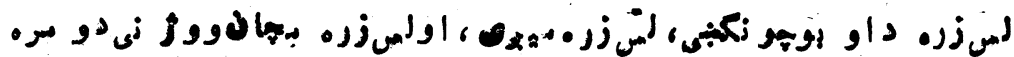

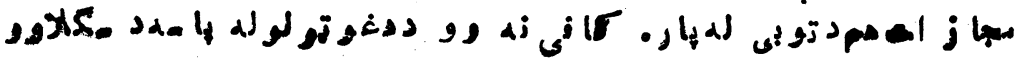

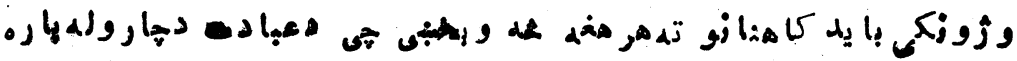

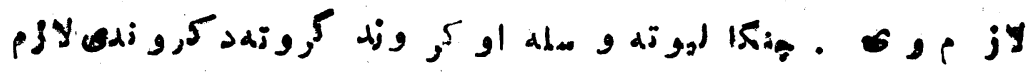

$$
\begin{aligned}
& \text { (1) . (1) } \\
& \text { ا }
\end{aligned}
$$

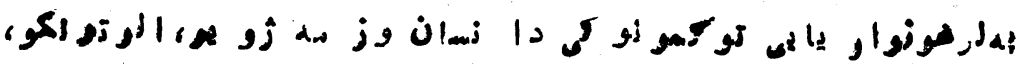

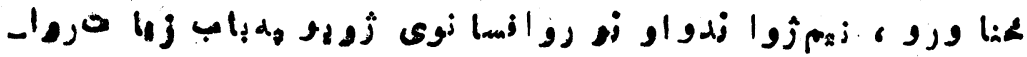

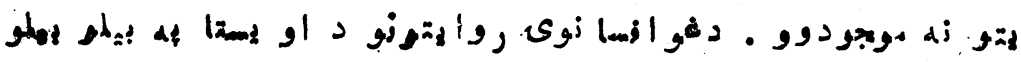

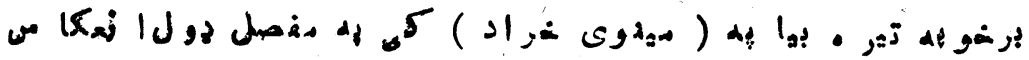

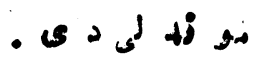

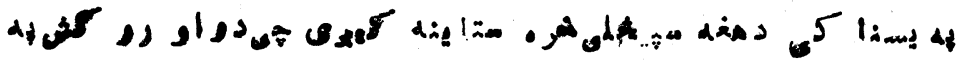

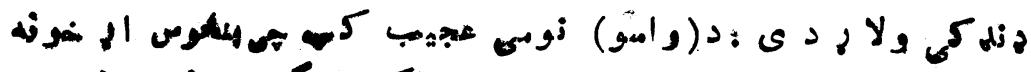

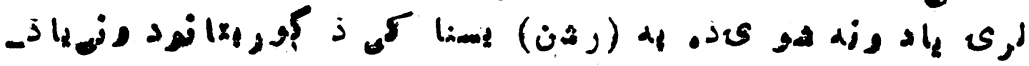

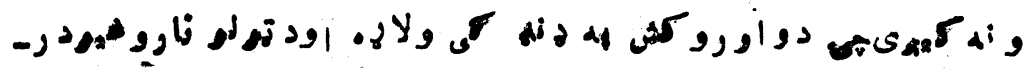

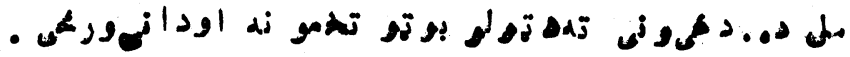

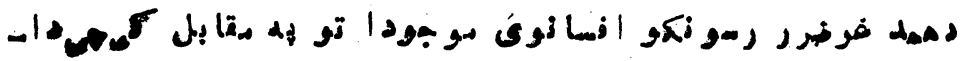

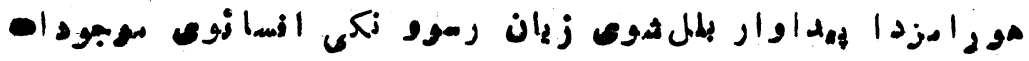

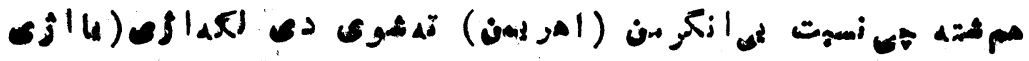

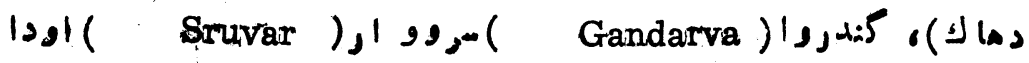

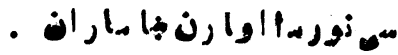

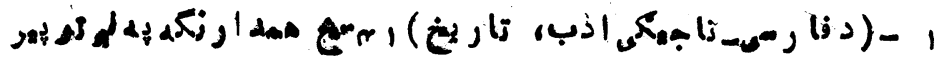

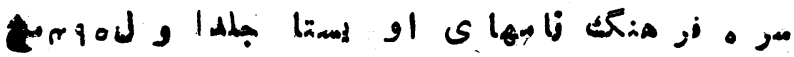




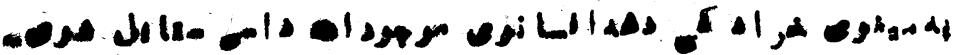

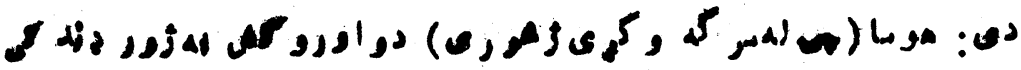

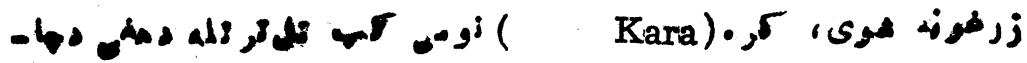

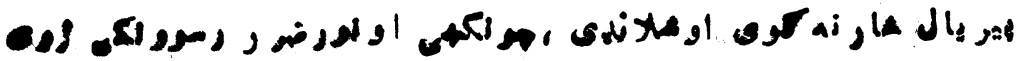

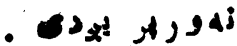

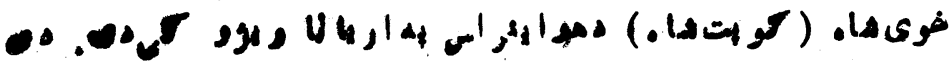

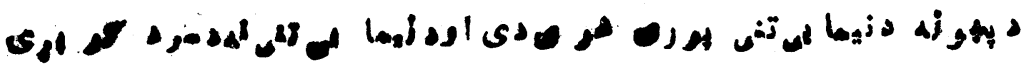

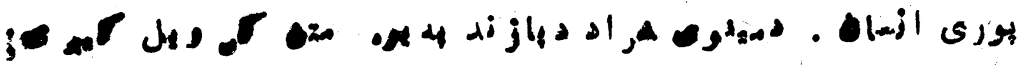

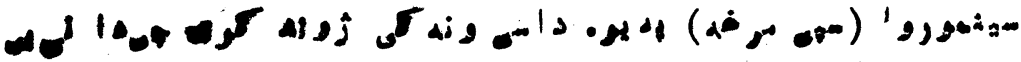

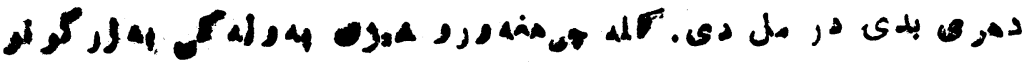

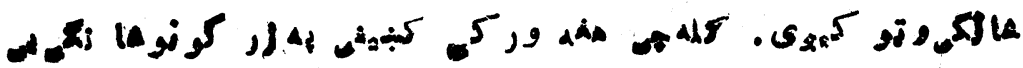

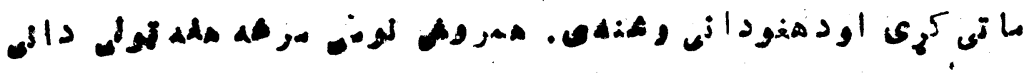

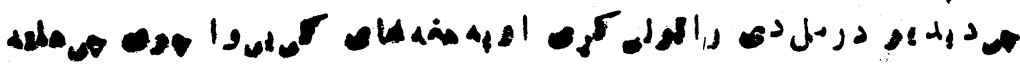

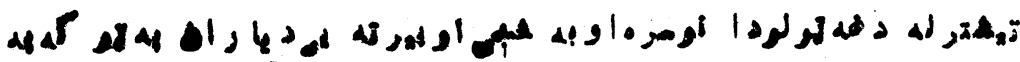

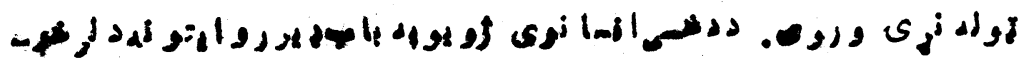

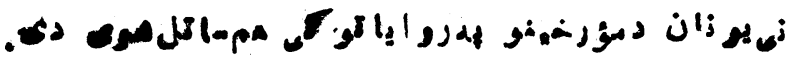

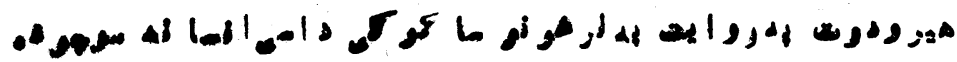

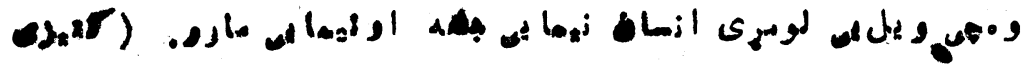

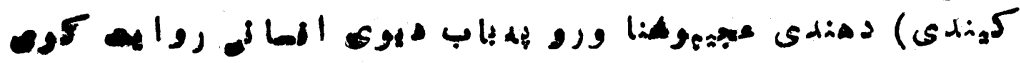
ثا

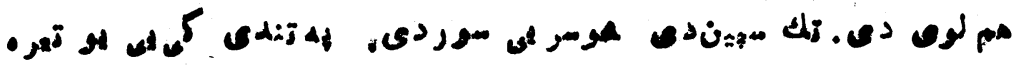

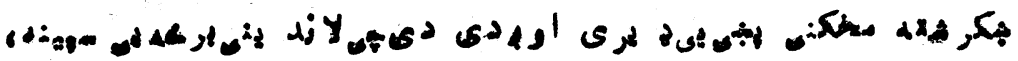


- .

$-1 \ldots$

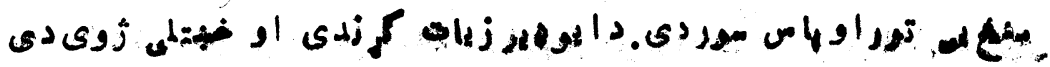

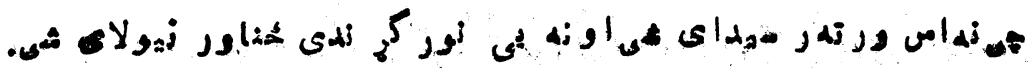

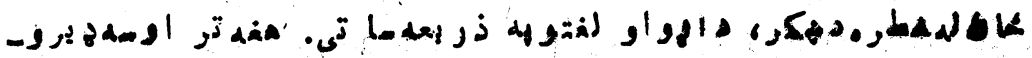

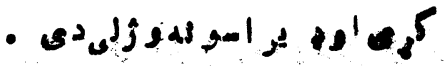

然

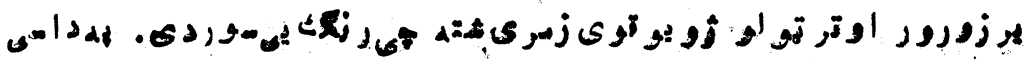

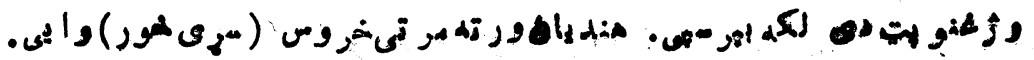

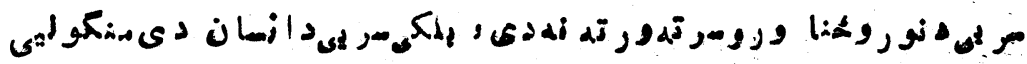

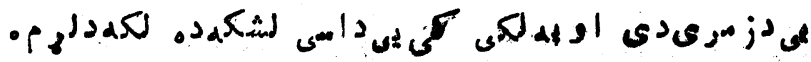

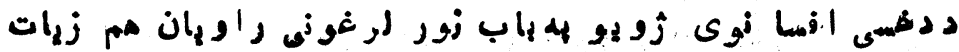

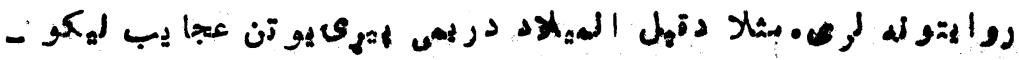

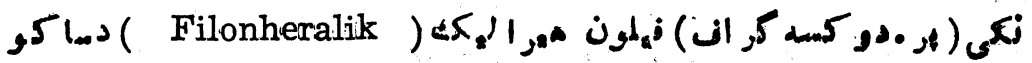

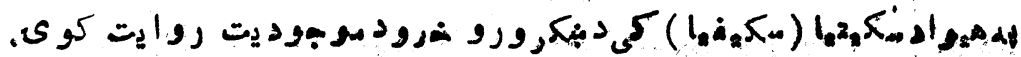
.

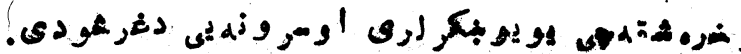

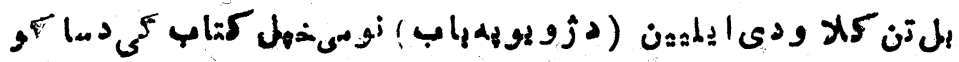

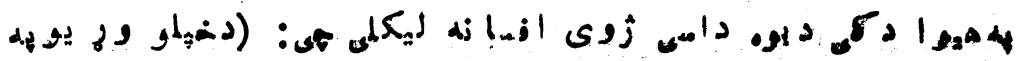

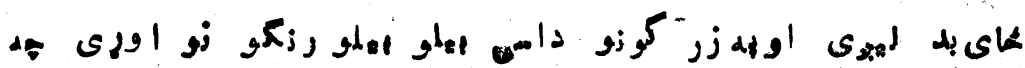

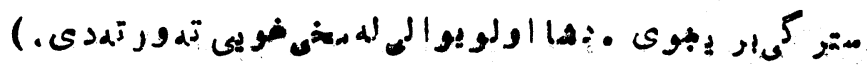

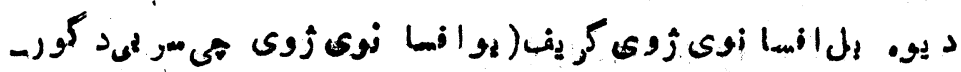

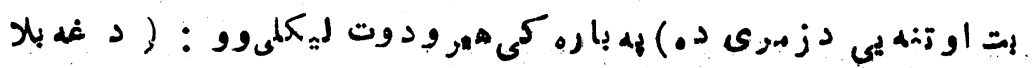

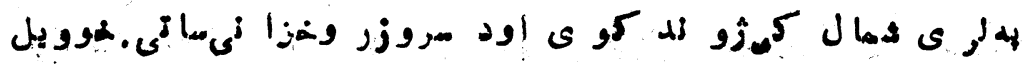




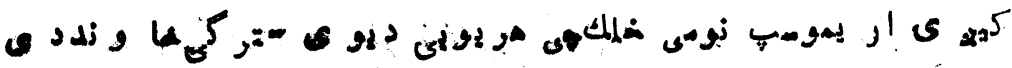

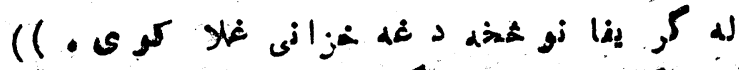

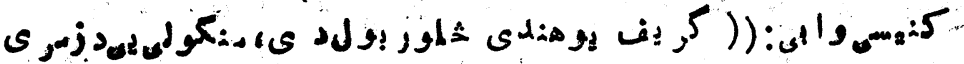
دى

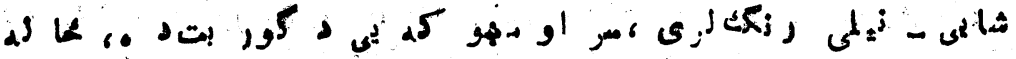
)

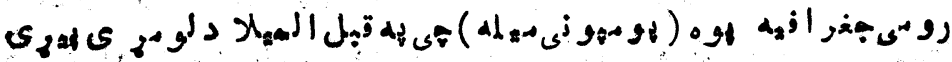

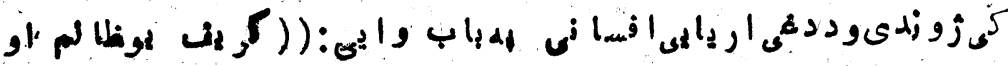

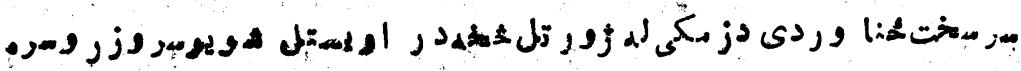

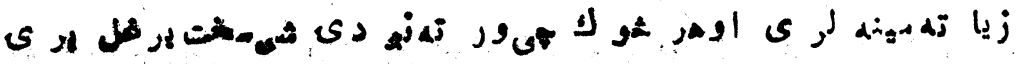

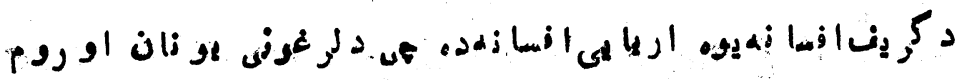

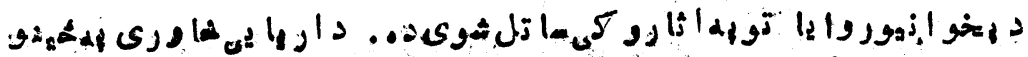

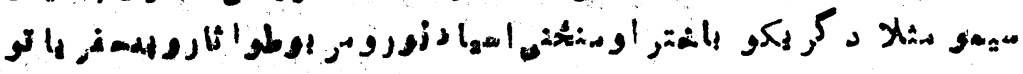

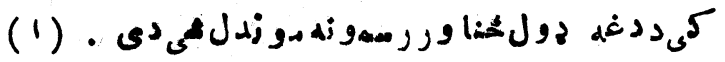

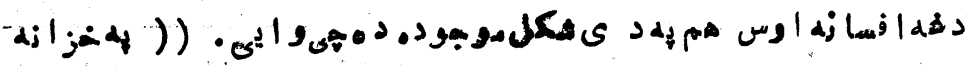

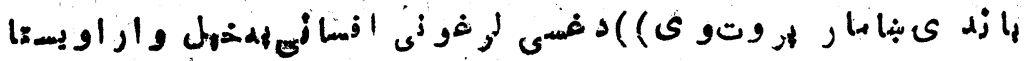

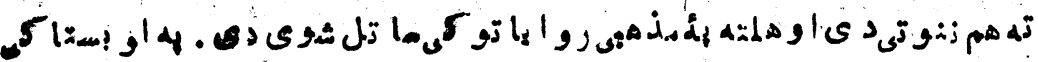

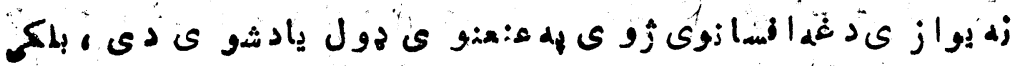

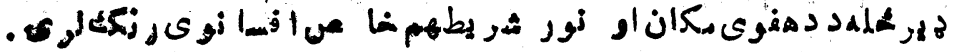

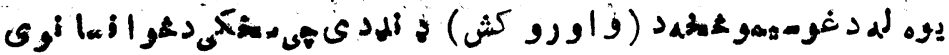

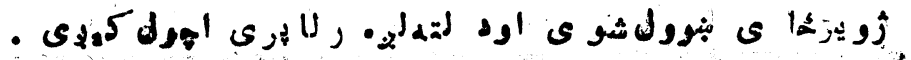

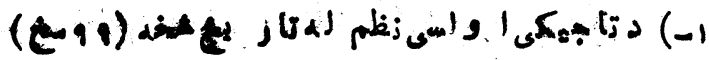




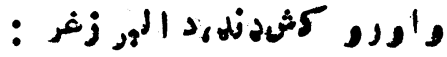

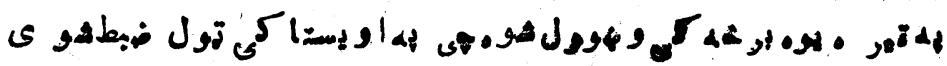

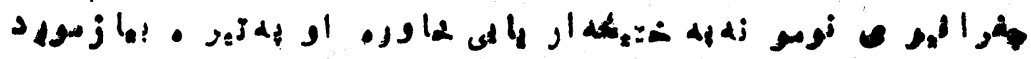

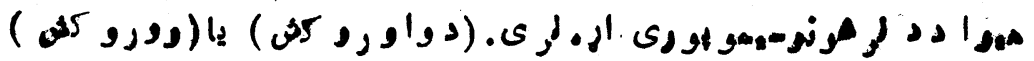

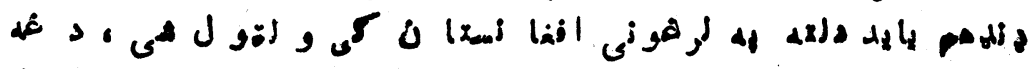

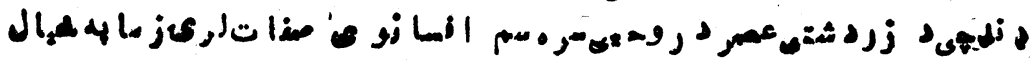

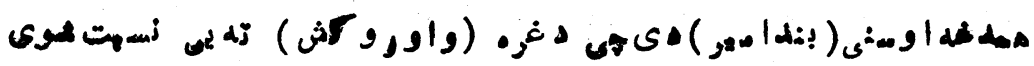

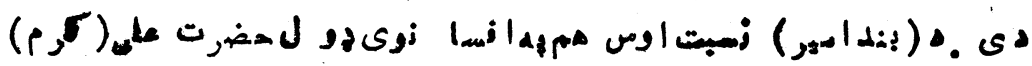

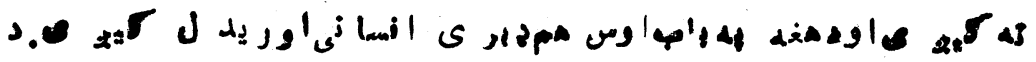

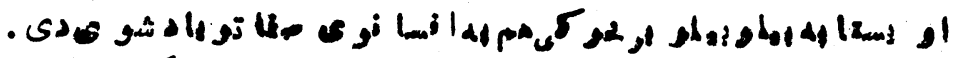

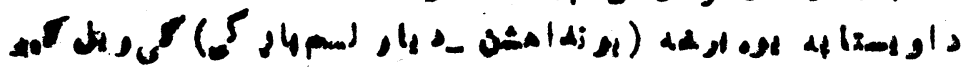

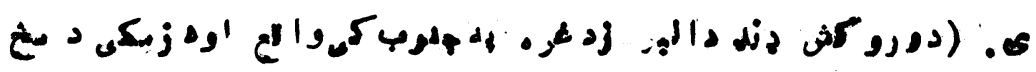

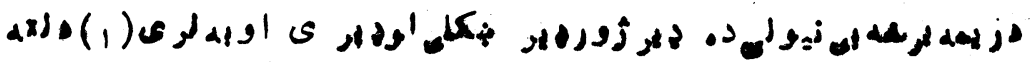

$$
\begin{aligned}
& \text {. } \\
& \text { أله }
\end{aligned}
$$

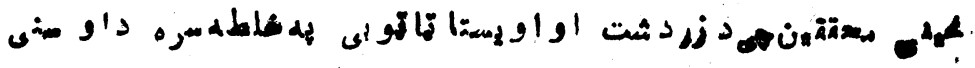

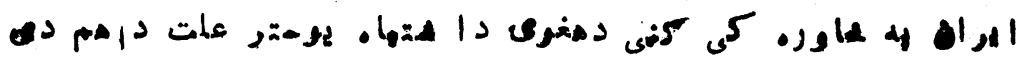

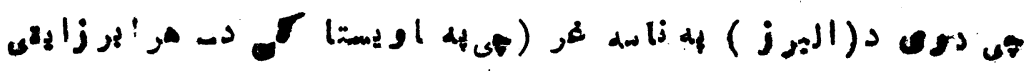

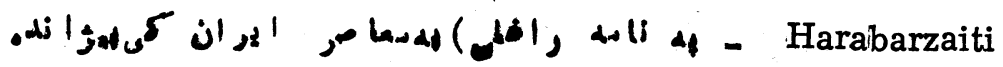

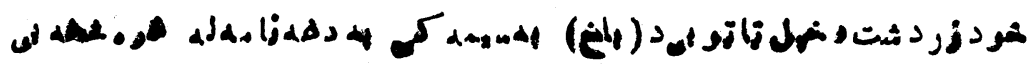
ثهره ود.

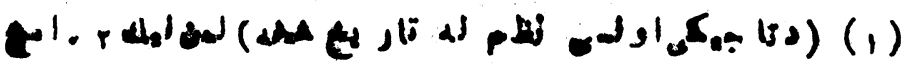


$-1 \cdot r-$

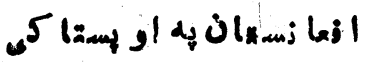

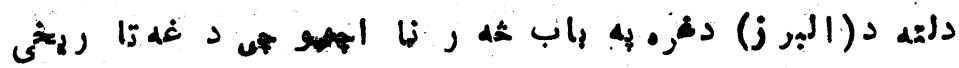

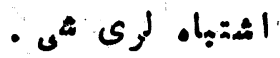

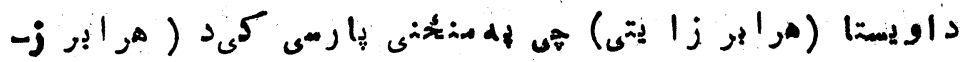

( اوله (Haraborz)

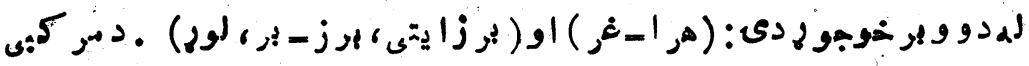

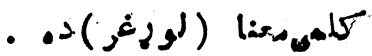

د)

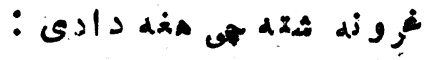

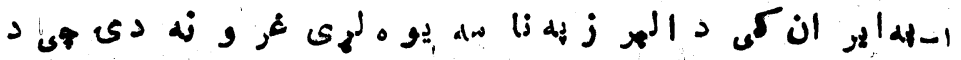

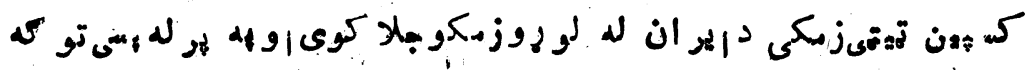

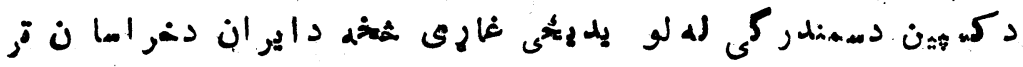

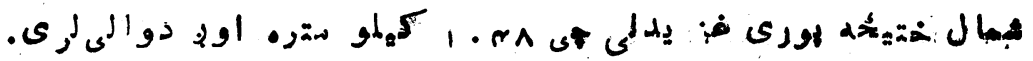

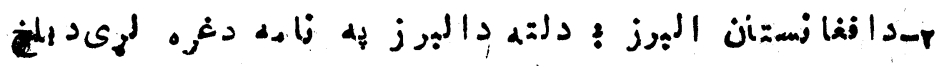

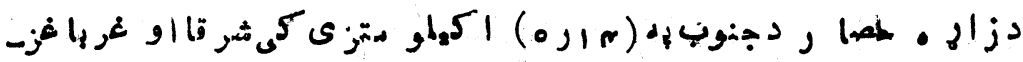

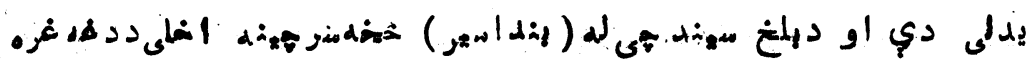

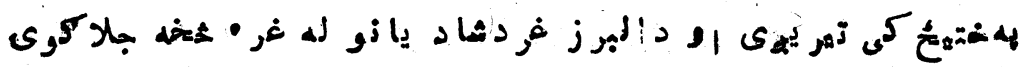

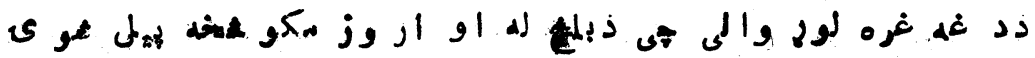

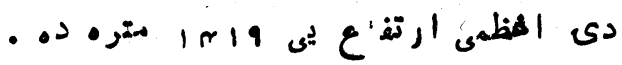

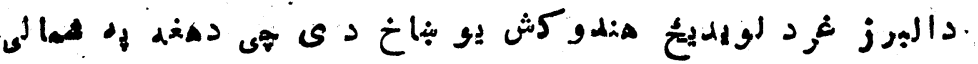

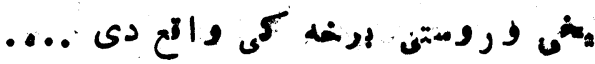

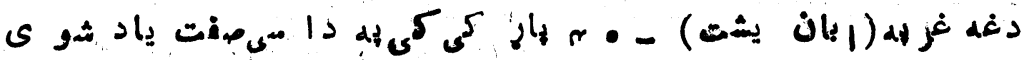

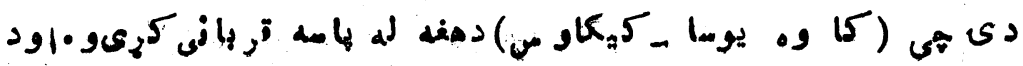




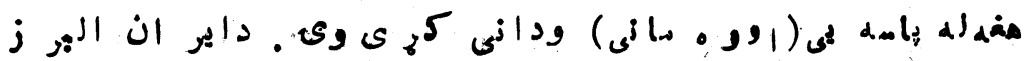

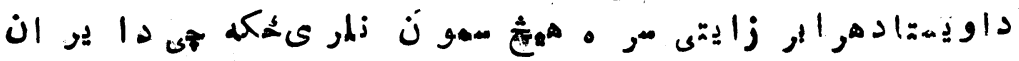

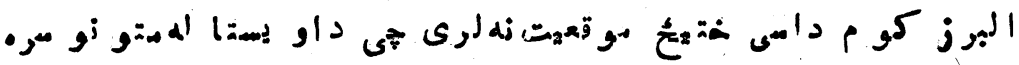

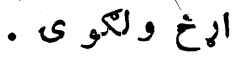

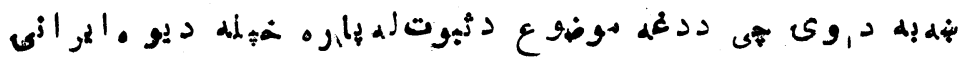

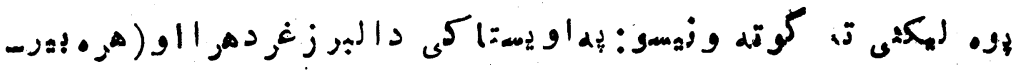

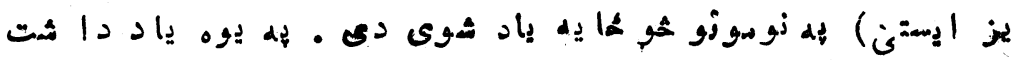

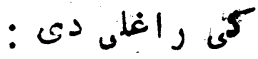

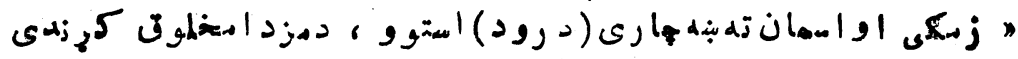

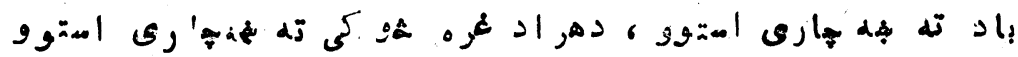

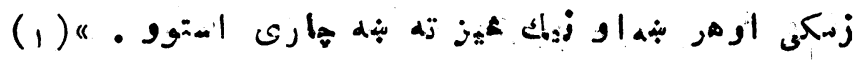

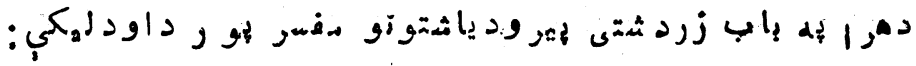

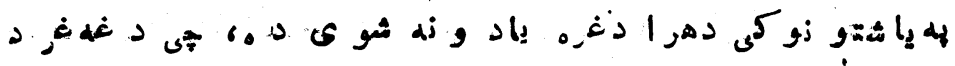

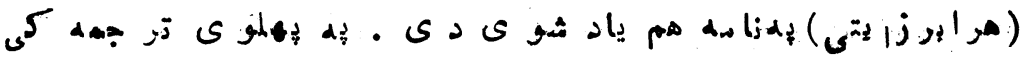

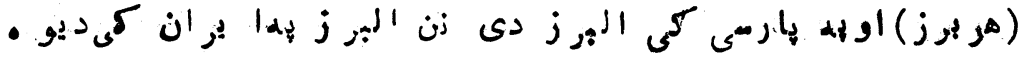

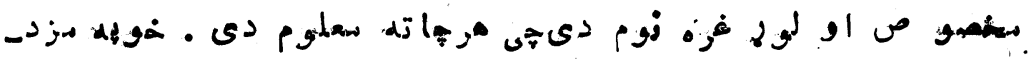

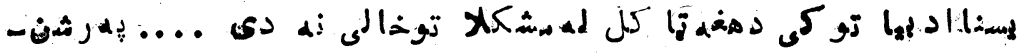

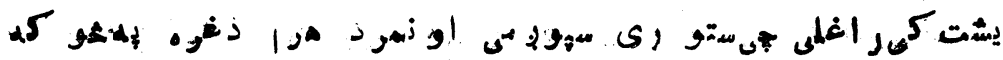
- . .

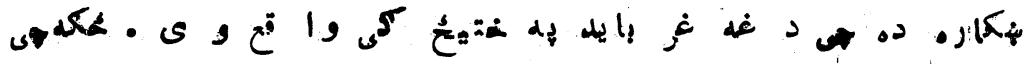

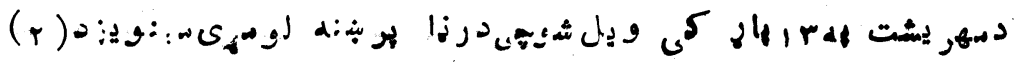

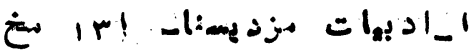

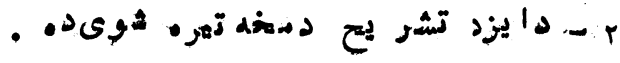




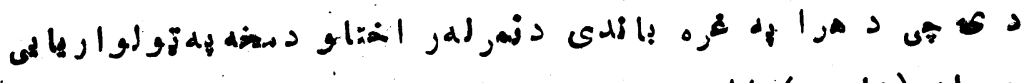

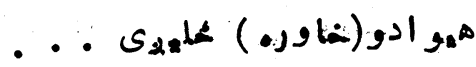

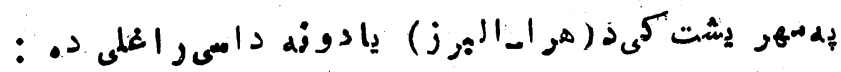

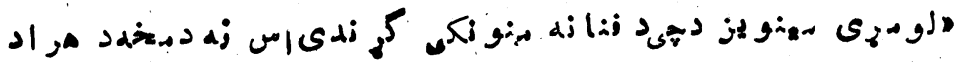

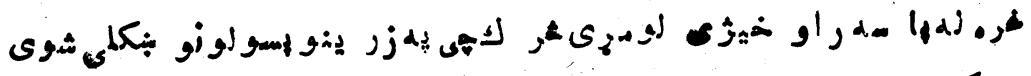

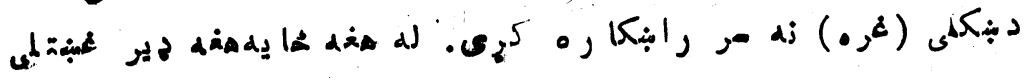

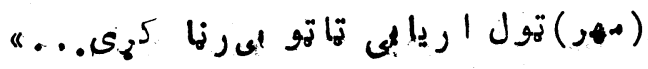

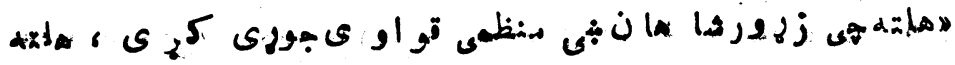

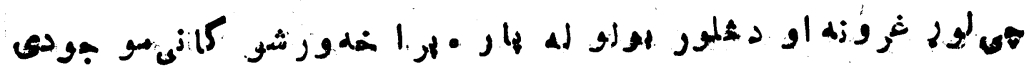

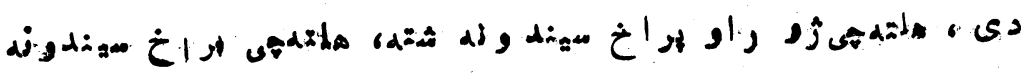

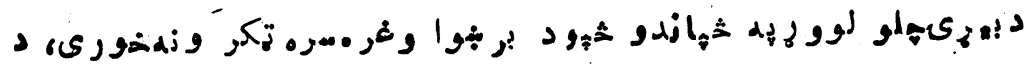

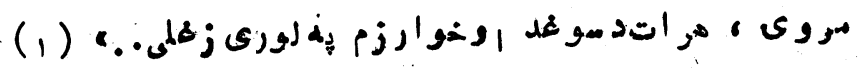

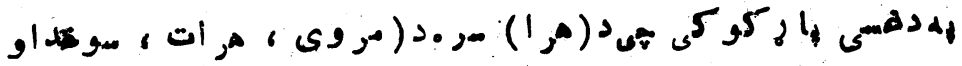

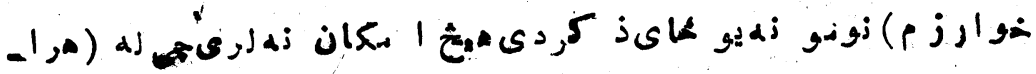

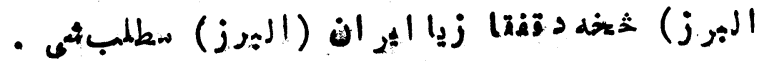

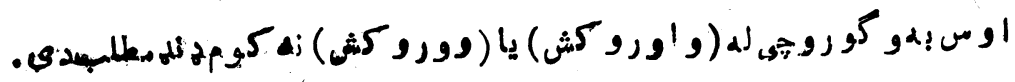

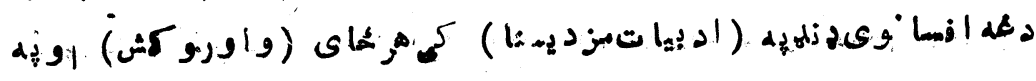
زو رونا ندذو نو كى (وو روكش) ليكل شوى كدى.

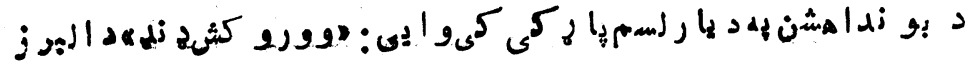

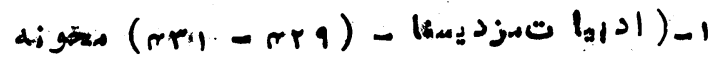




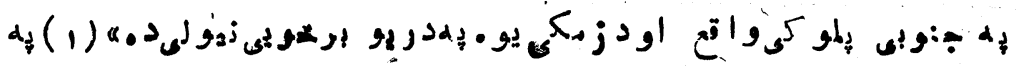

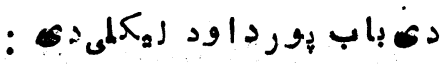

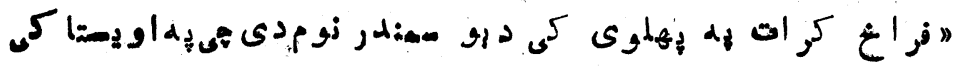

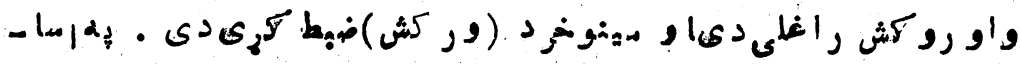

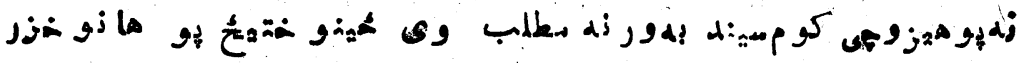

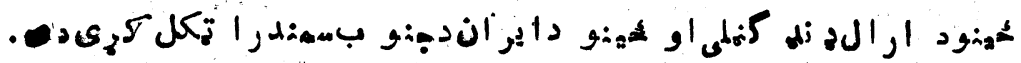

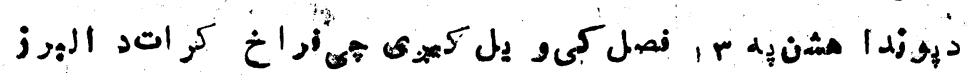

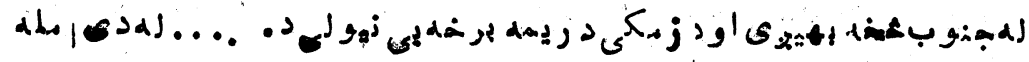

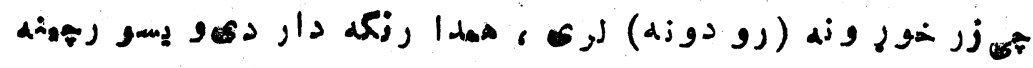

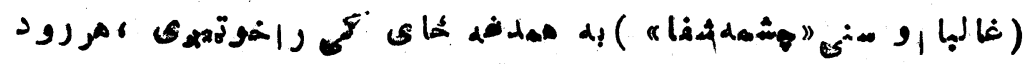

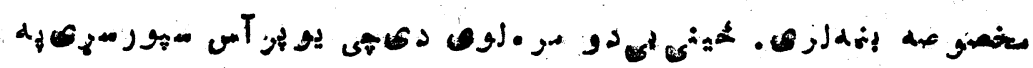

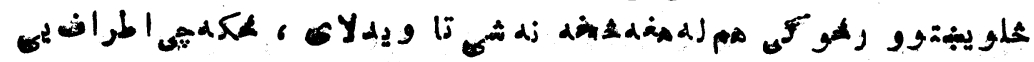

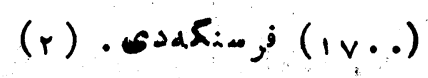

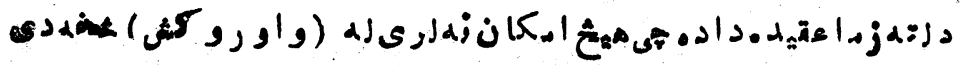

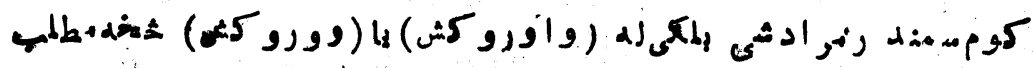

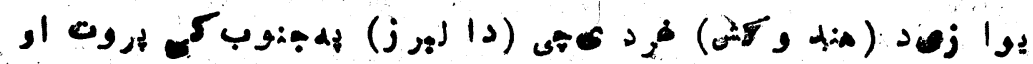

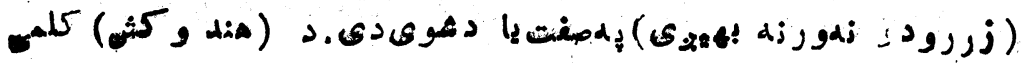

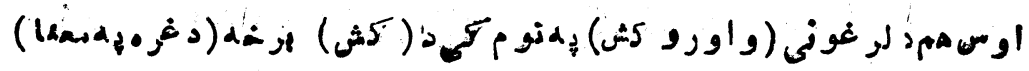

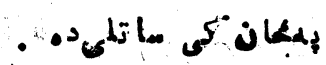

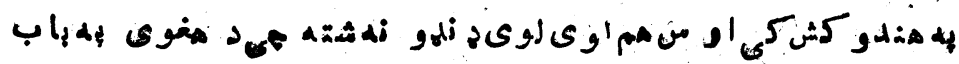

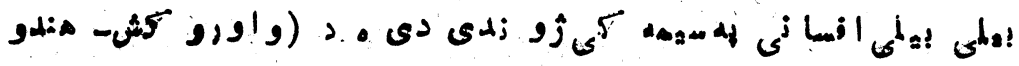

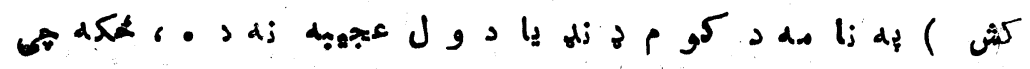

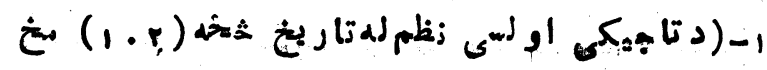

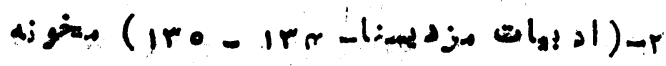


$-1 \cdot v^{2}$

ا

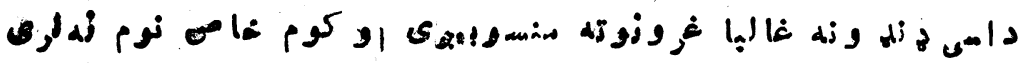

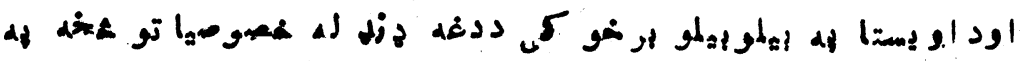

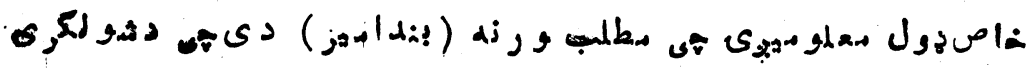

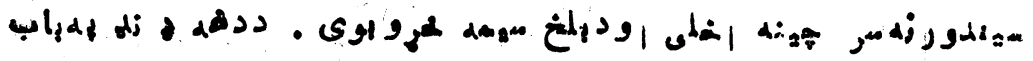

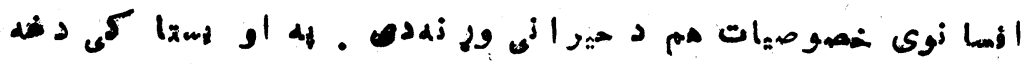

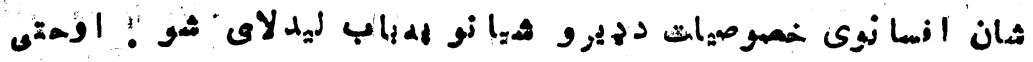

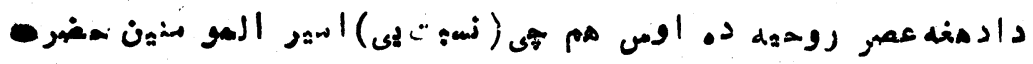

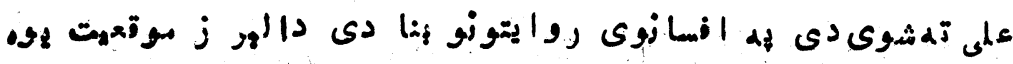

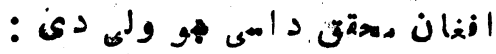

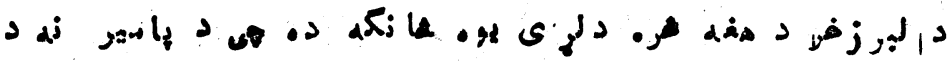

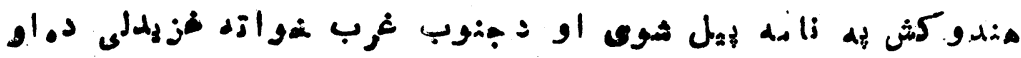

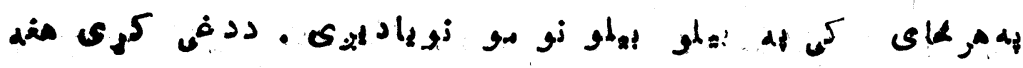

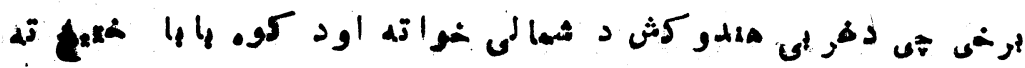

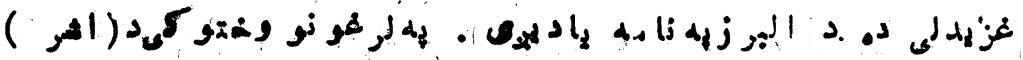

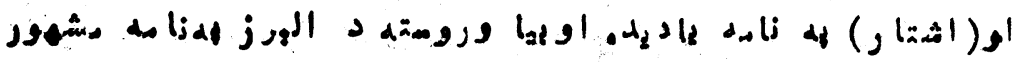

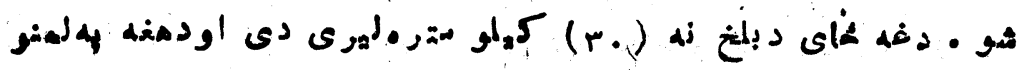

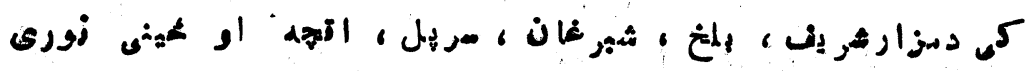

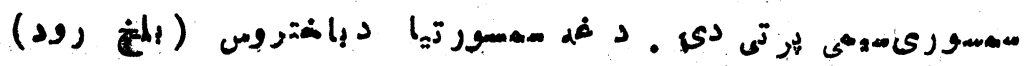

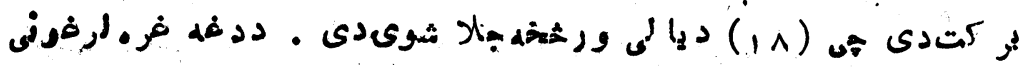

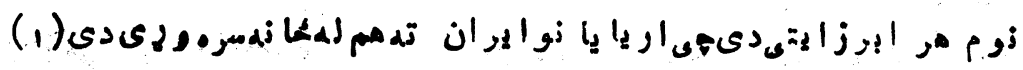

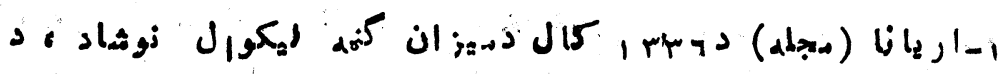

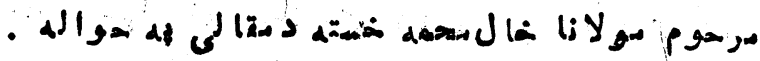




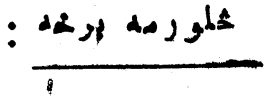

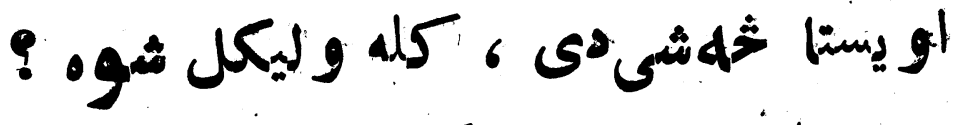

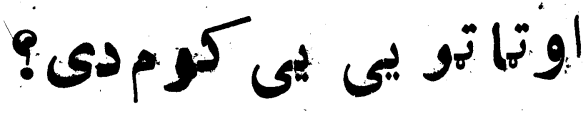

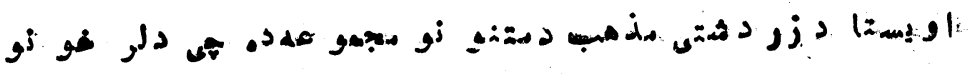

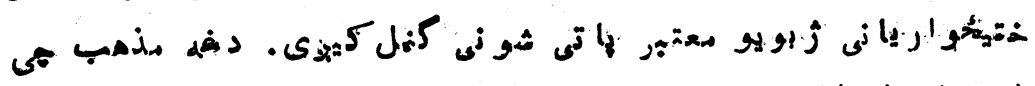

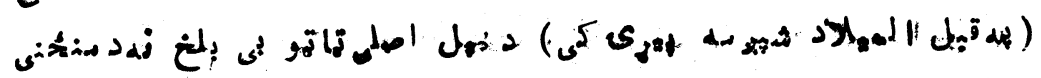

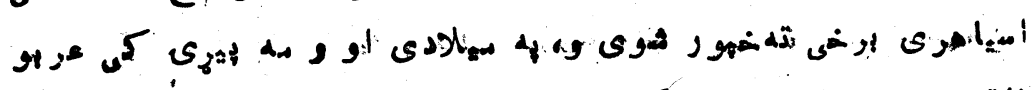

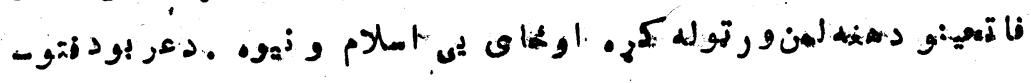

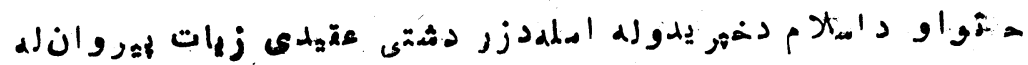

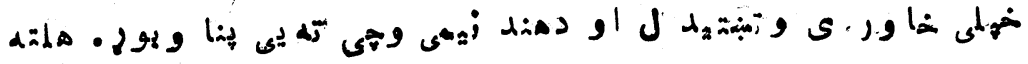

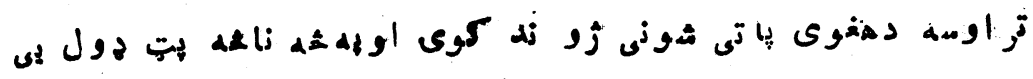

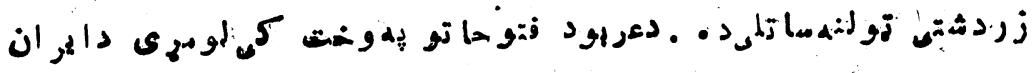

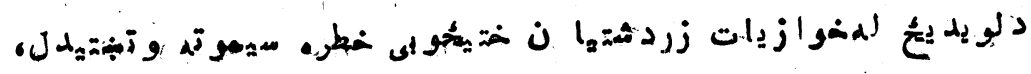

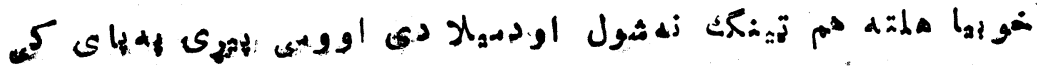


$-1.9-$

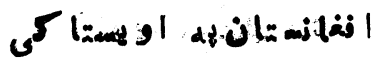

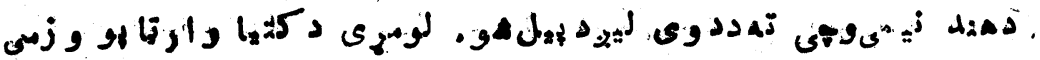

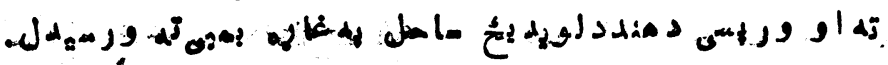

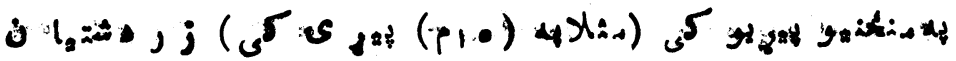

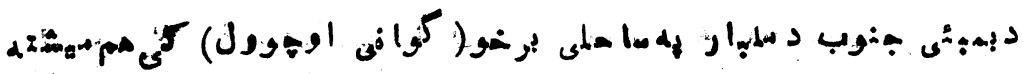

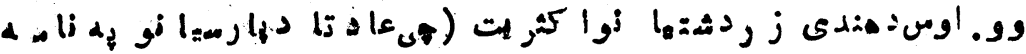

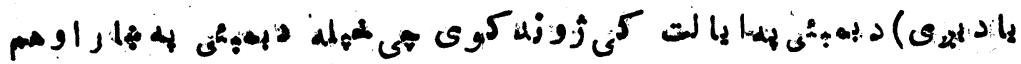

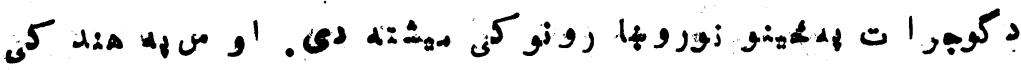

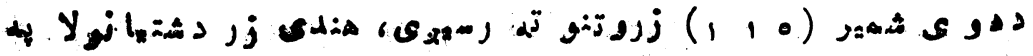

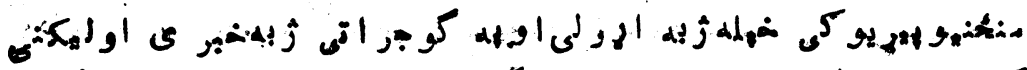

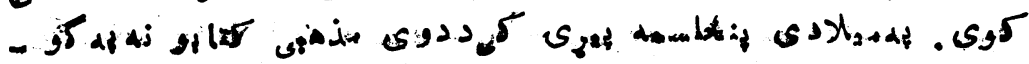

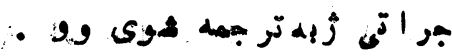

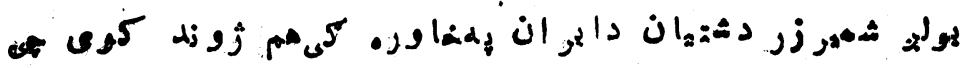

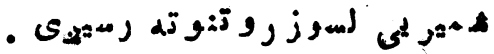

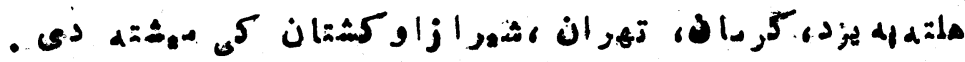

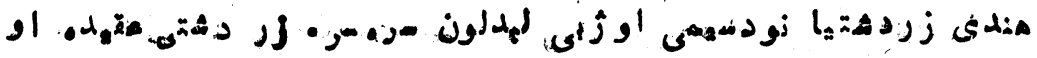

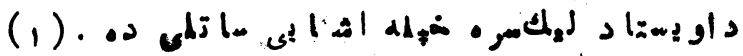

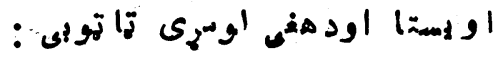

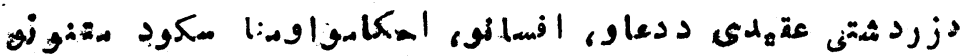

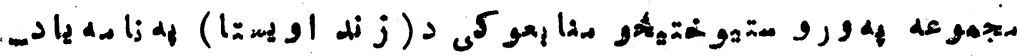

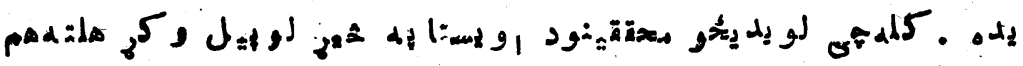

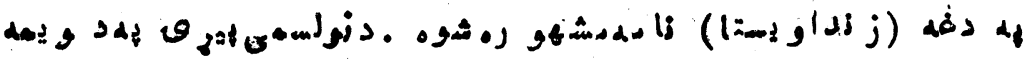

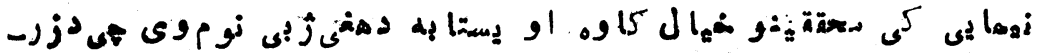

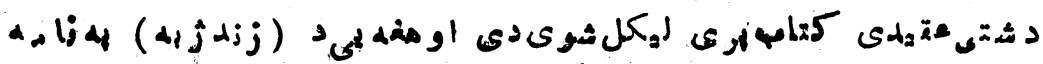

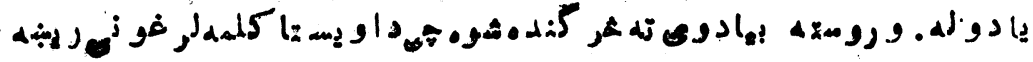

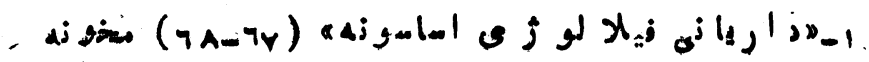




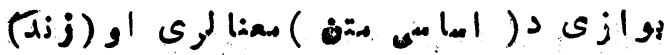

(Upasta $\left.\alpha^{x}-1 \rho^{\prime}\right)$

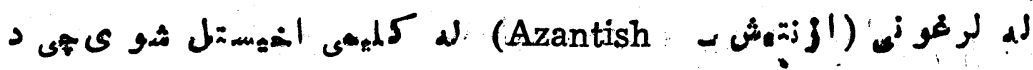

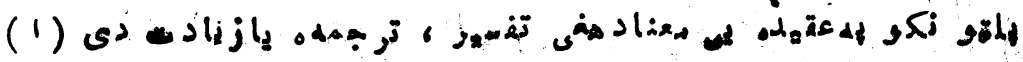

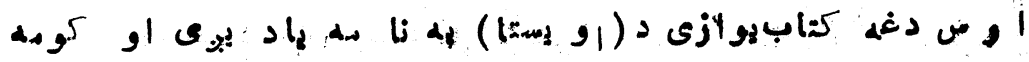

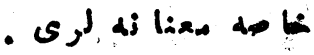

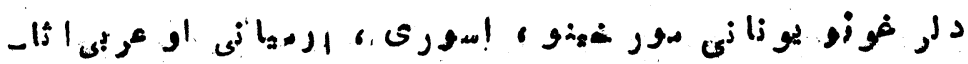

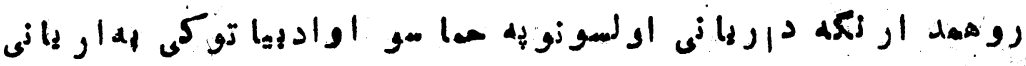

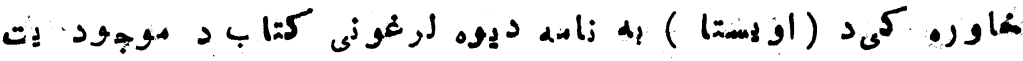

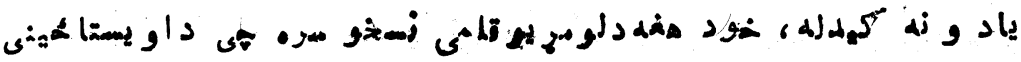

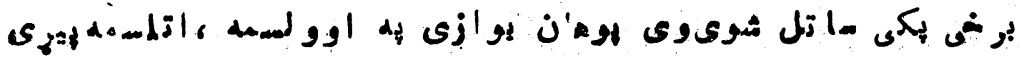

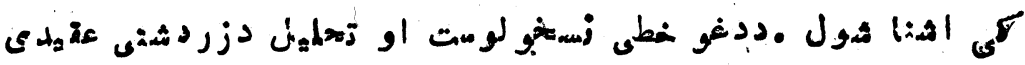

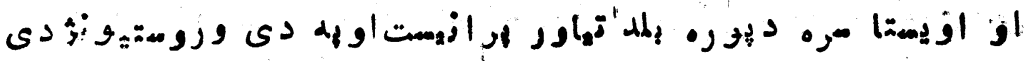

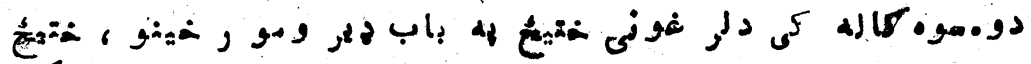

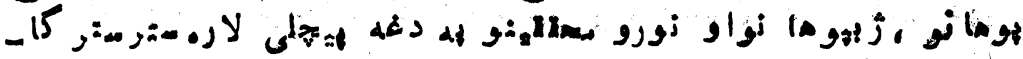

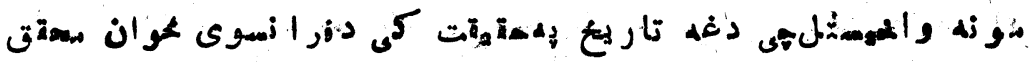

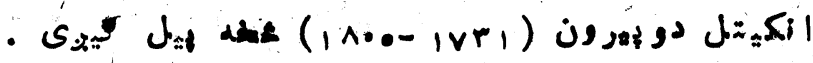

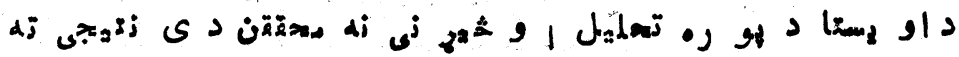

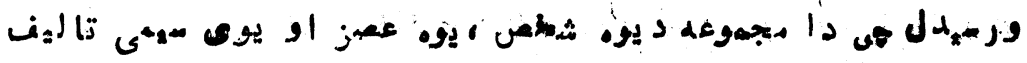

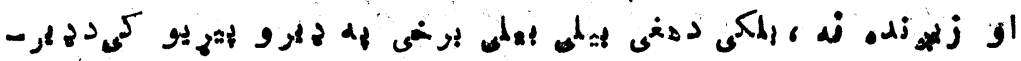

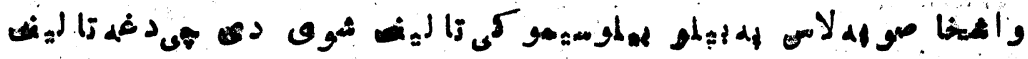
.

dإ

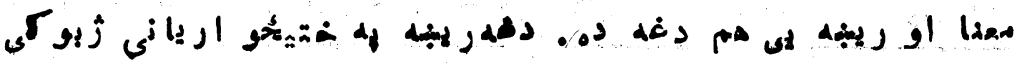
رو ندى ده 


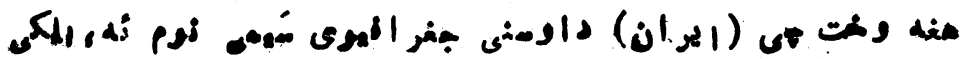
د (

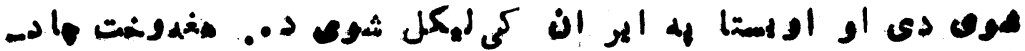

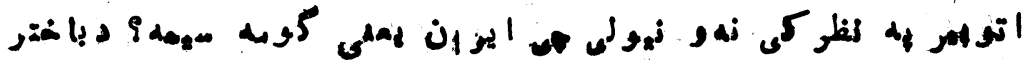

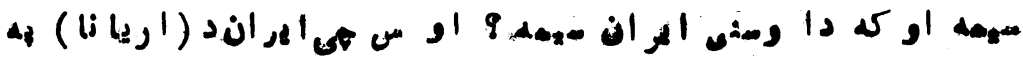

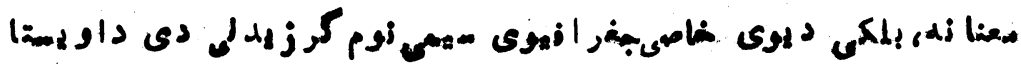

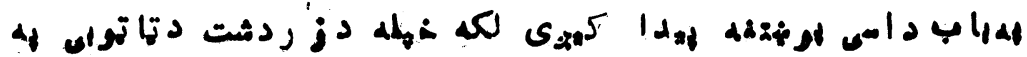

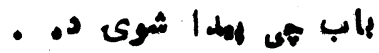

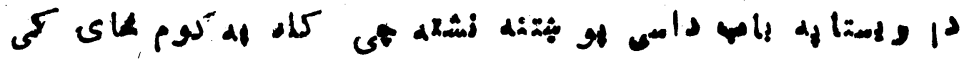

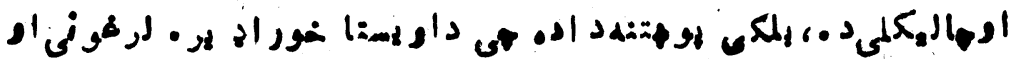

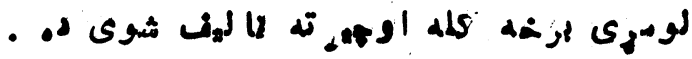

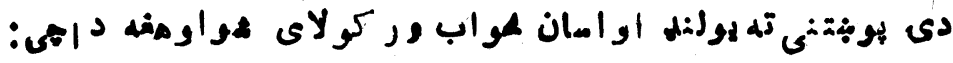

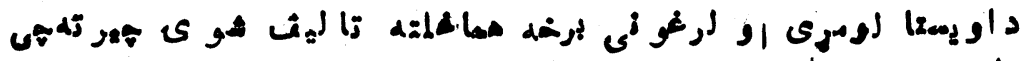

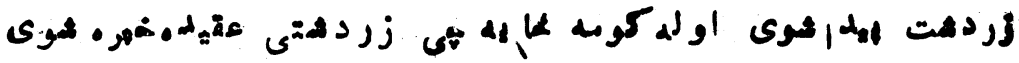

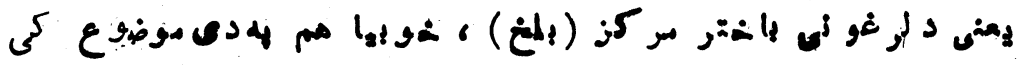

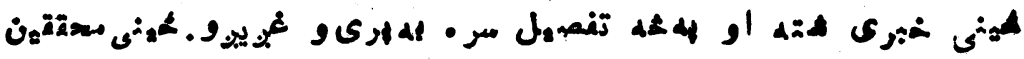

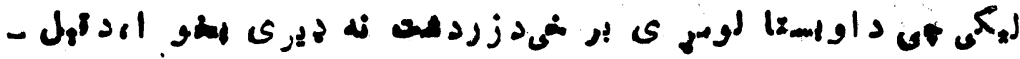

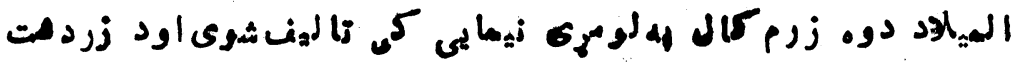

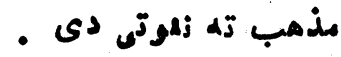

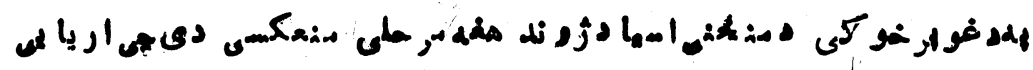

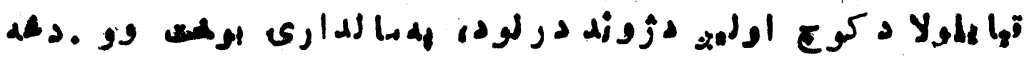

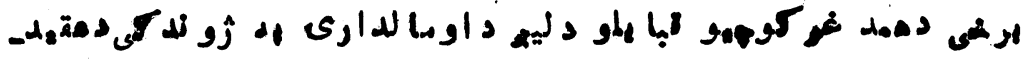

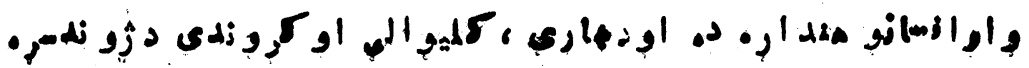




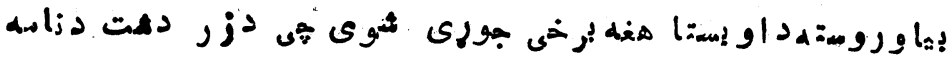

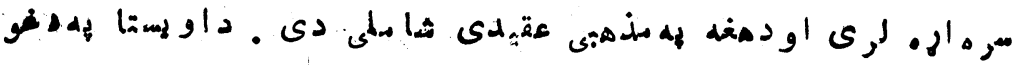

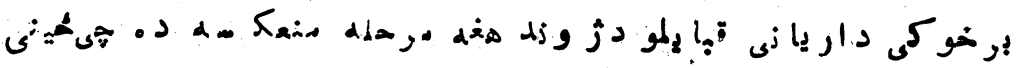

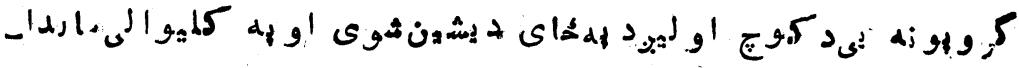

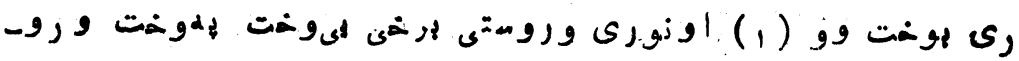

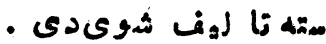

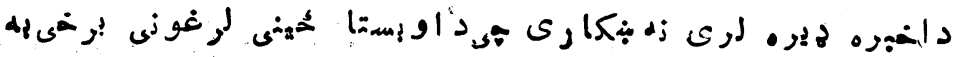

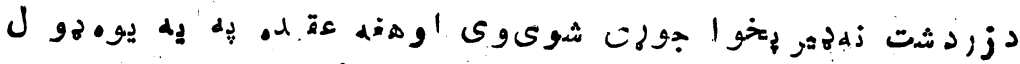

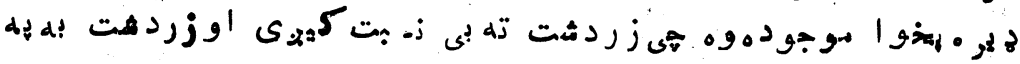

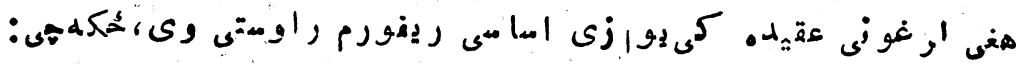

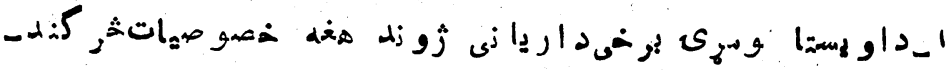

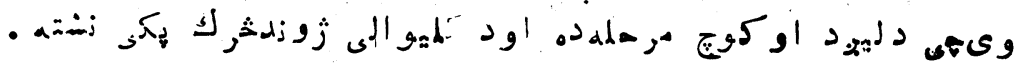

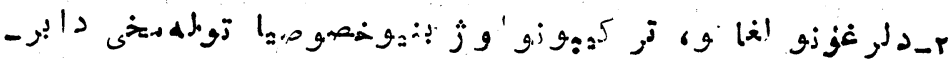

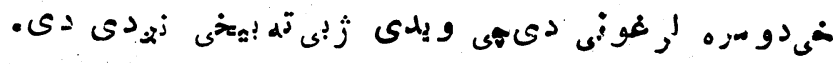

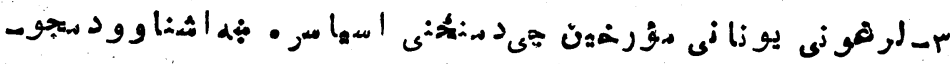

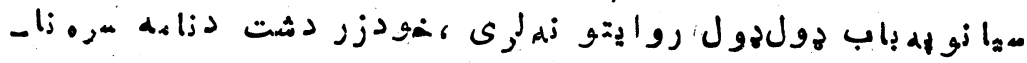

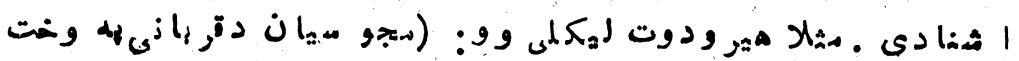

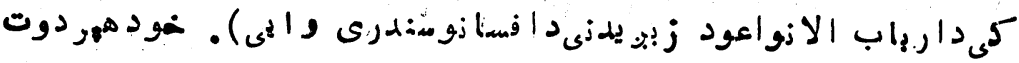

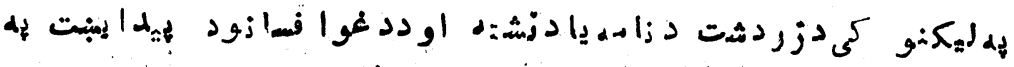

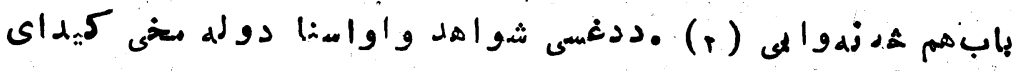

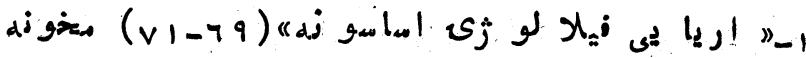

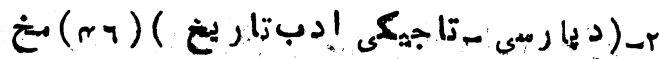




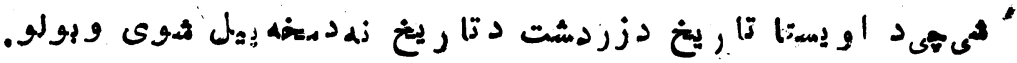

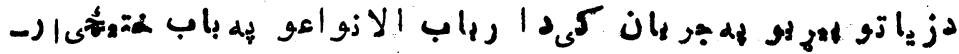

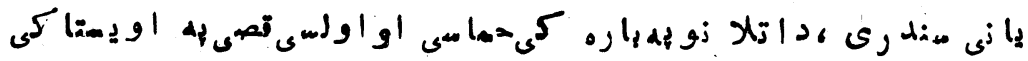

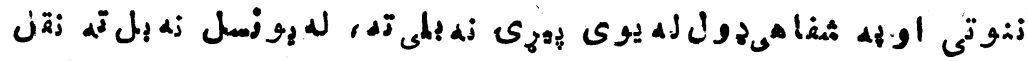

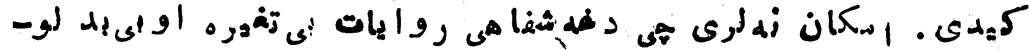

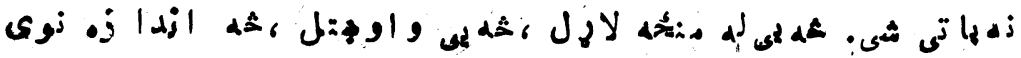

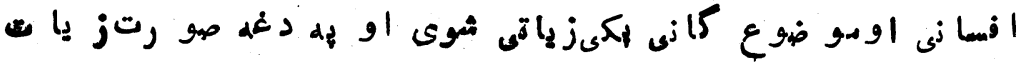

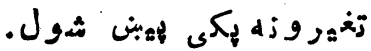

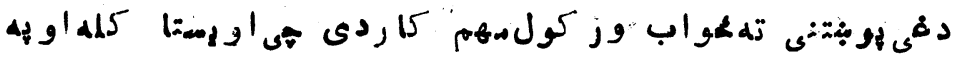

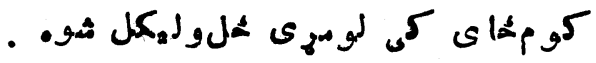

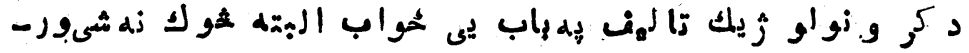

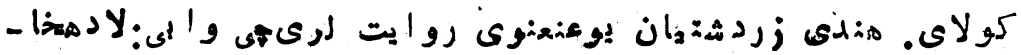

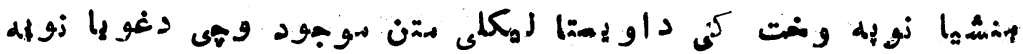

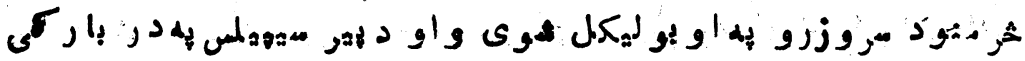

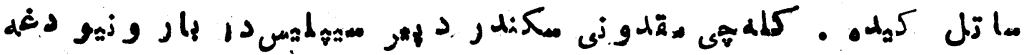

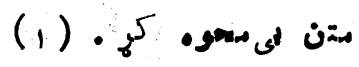

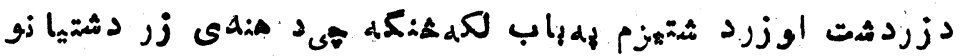

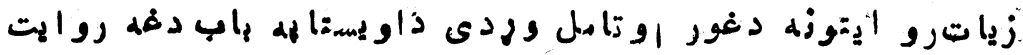

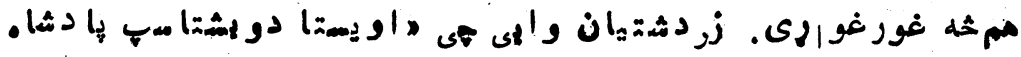

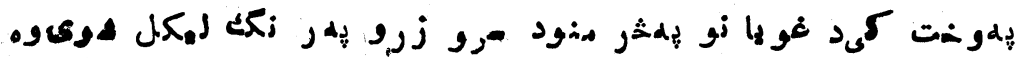

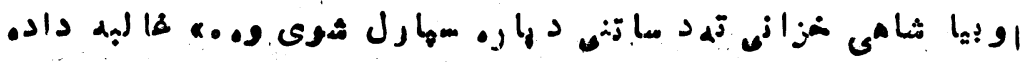

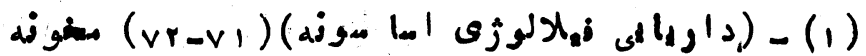




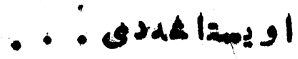

$-114$

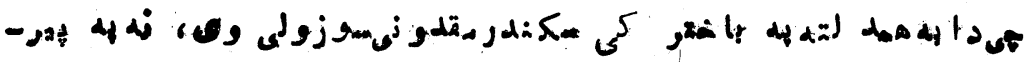

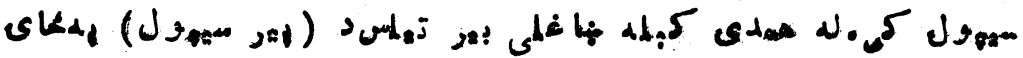

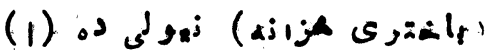

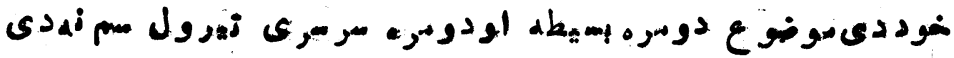

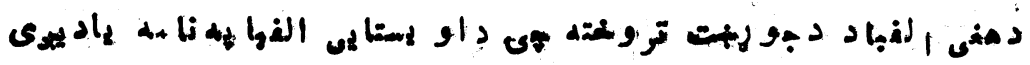

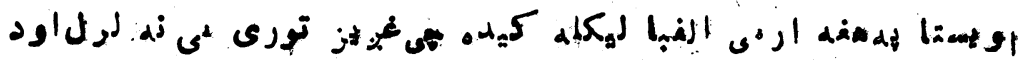

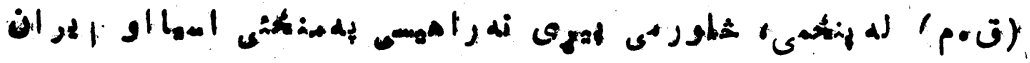

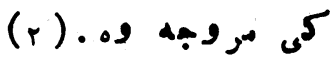

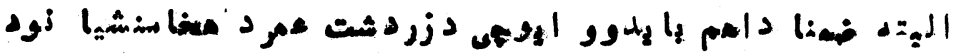

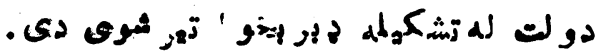

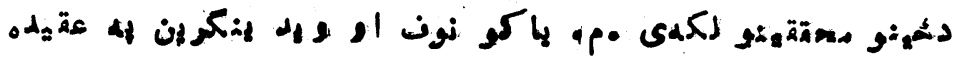

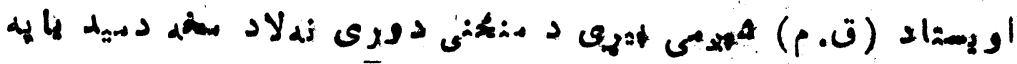

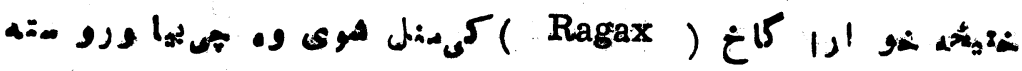

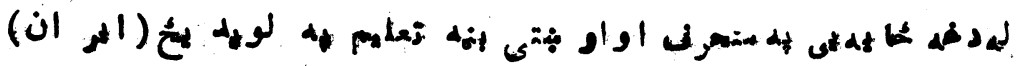

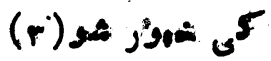

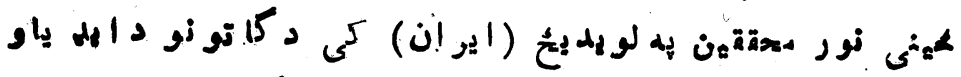

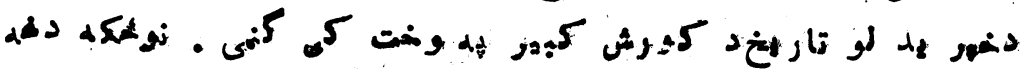

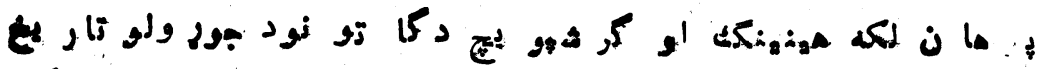

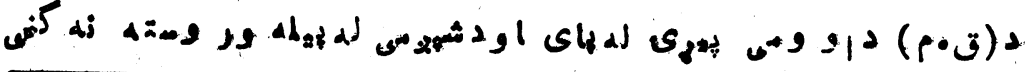

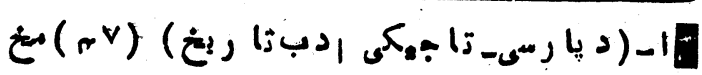

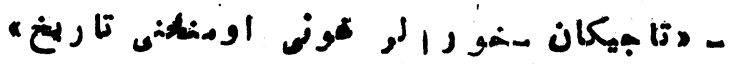
r. 
$-110$

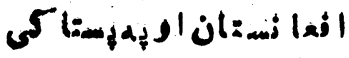

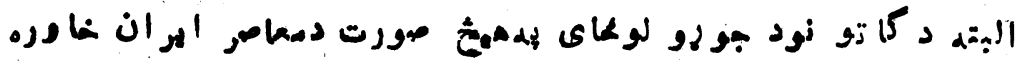

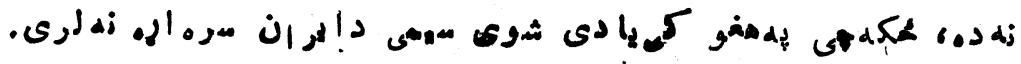

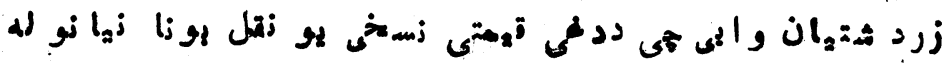

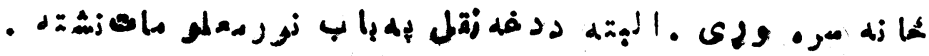

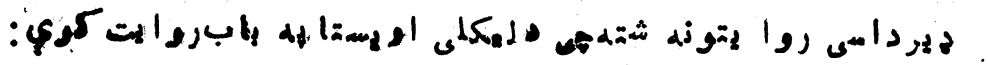

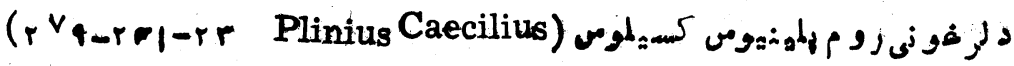

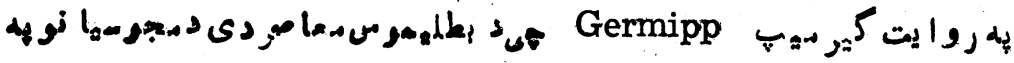

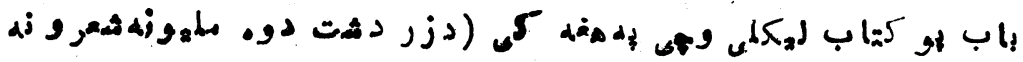

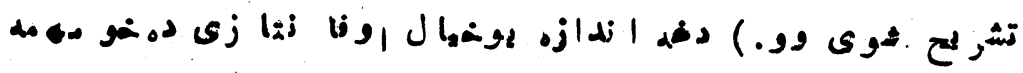

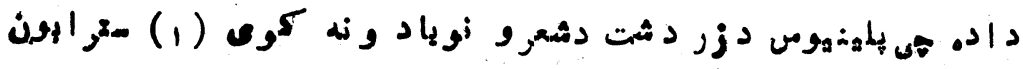

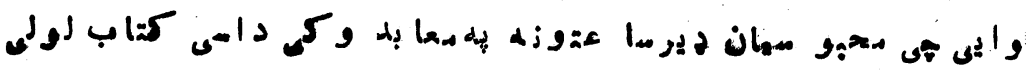
نه - لم

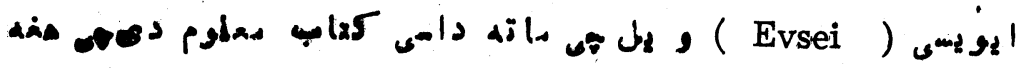

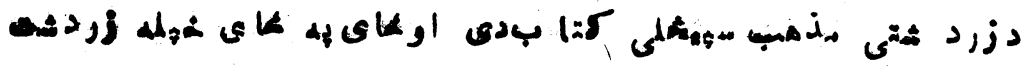
(r) (j) J

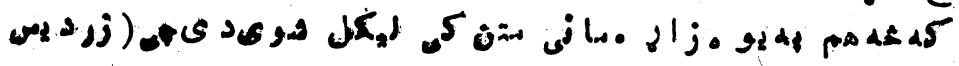

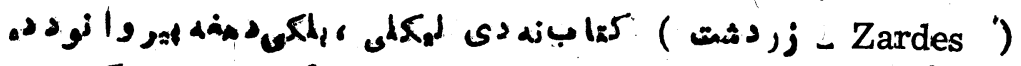

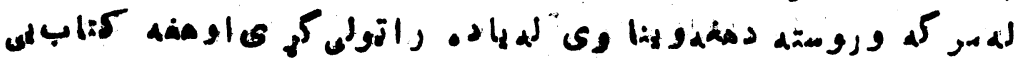

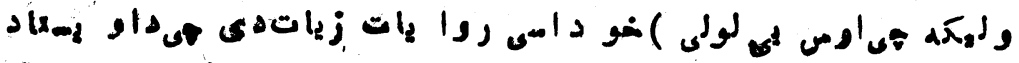

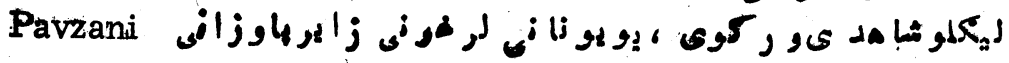

1-

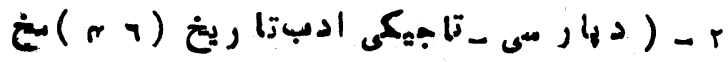




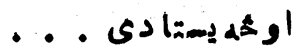

$-119-$

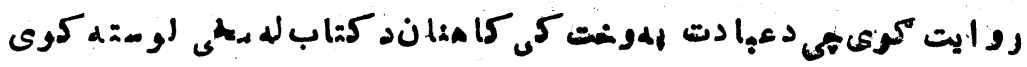

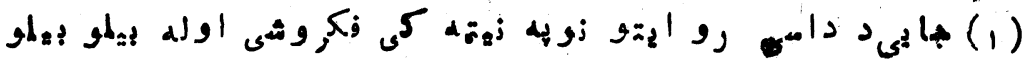

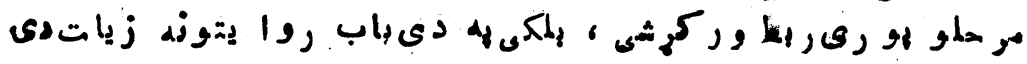

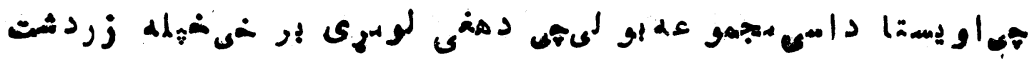

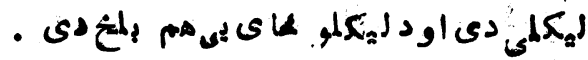

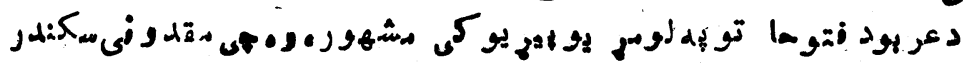

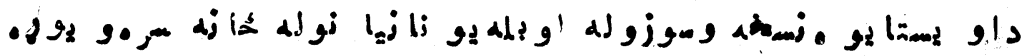

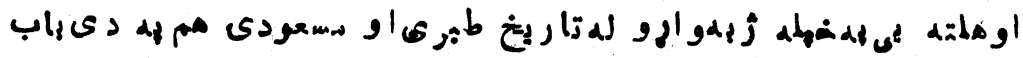

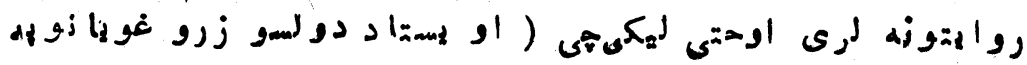

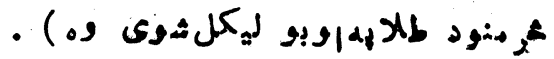

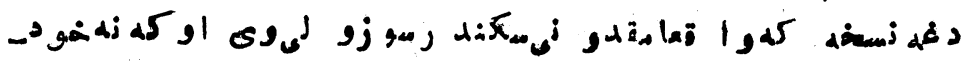

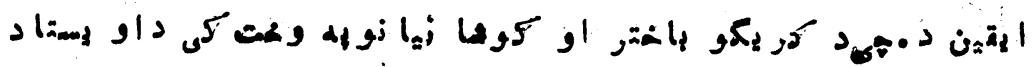

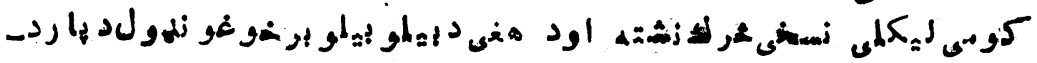

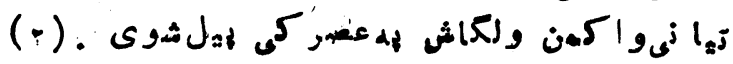

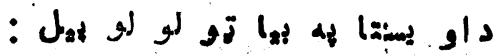

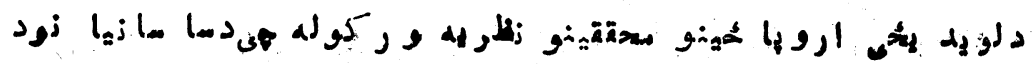

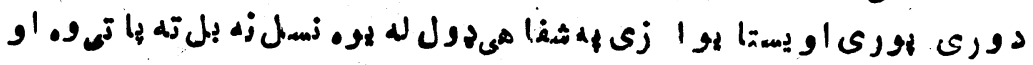

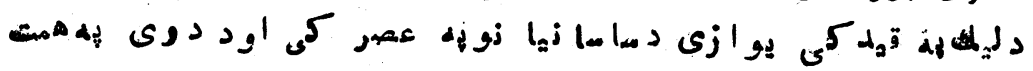

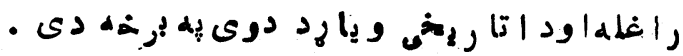

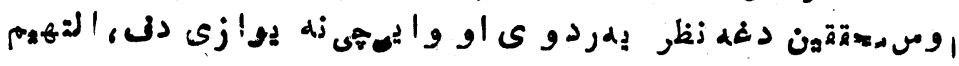
(Altheim).

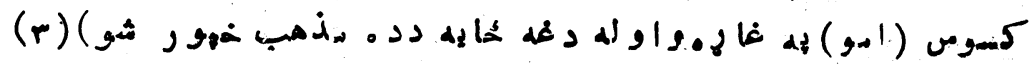

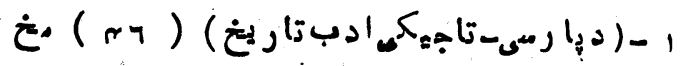

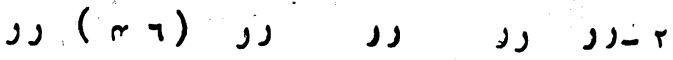

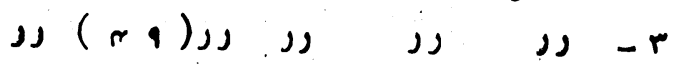


$-116$

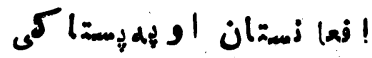

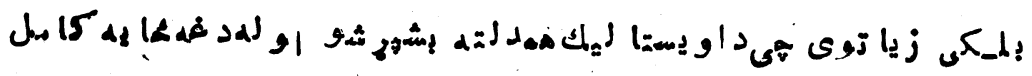

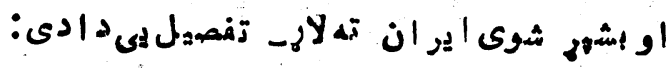

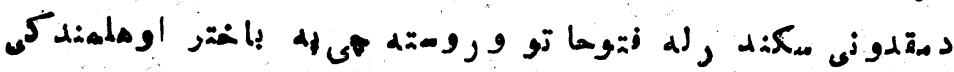

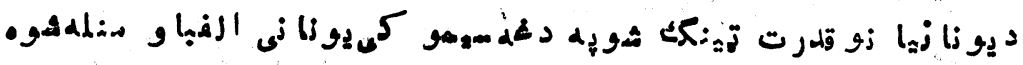

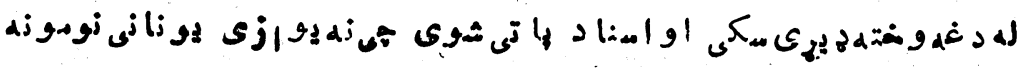

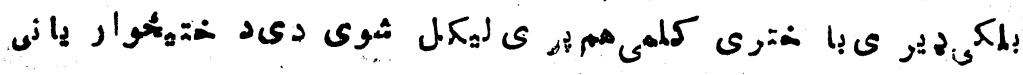
)

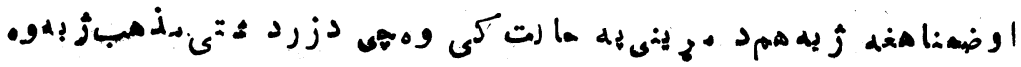

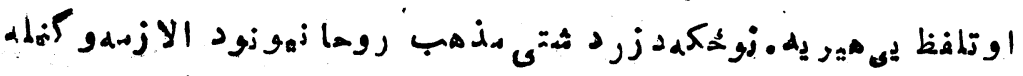

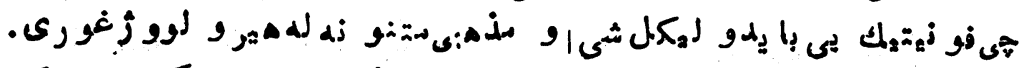

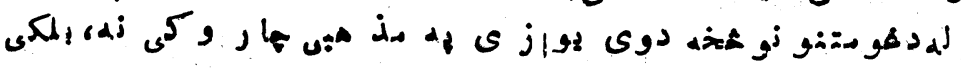

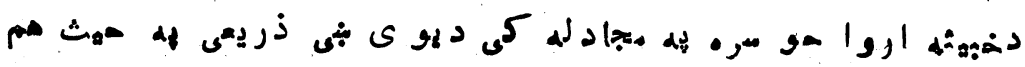

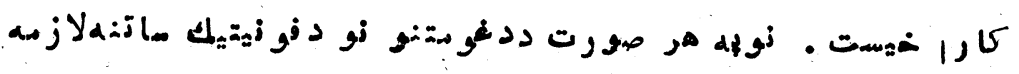

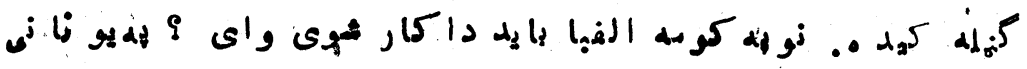

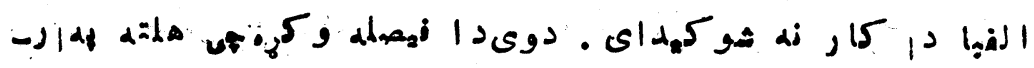

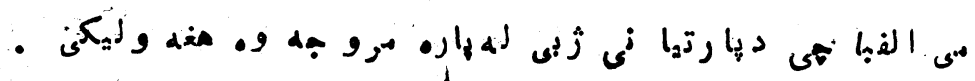

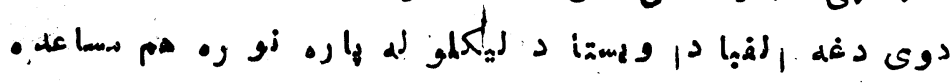

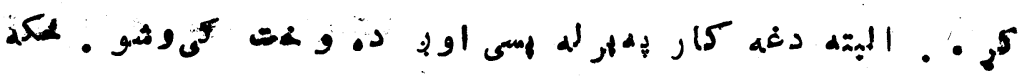

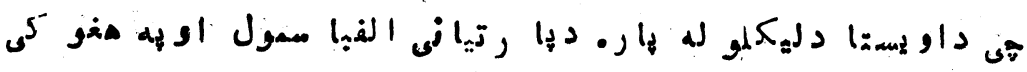

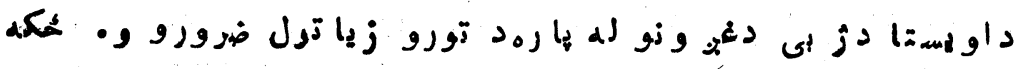

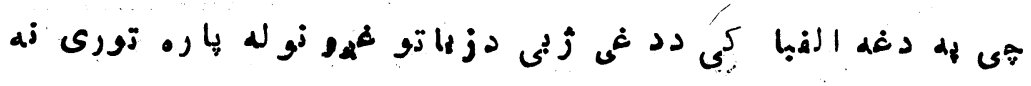

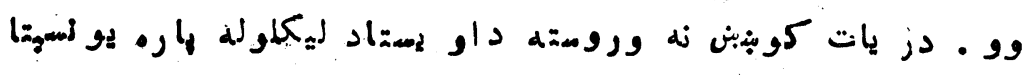

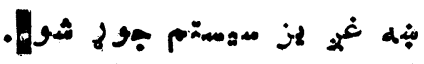




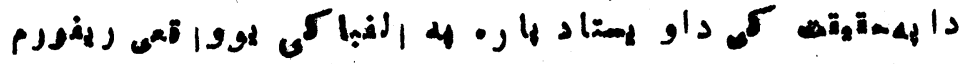

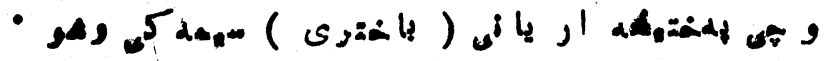

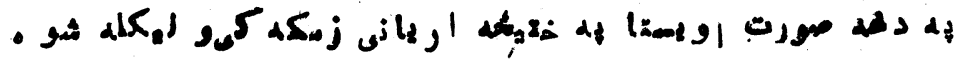
- ot oا

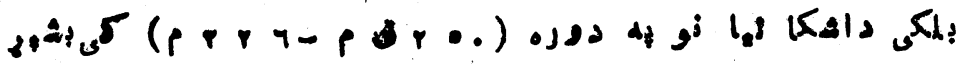

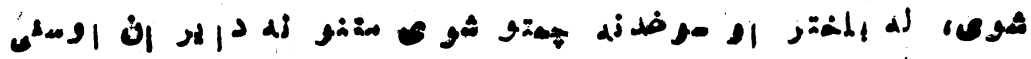

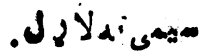

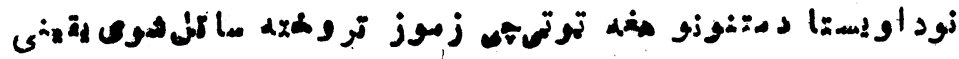

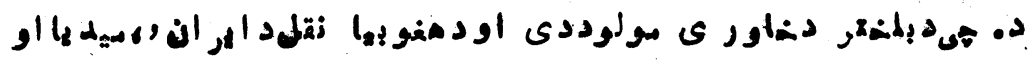

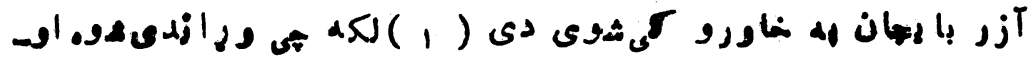

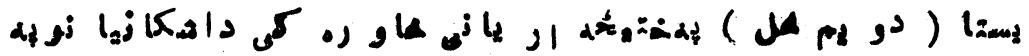

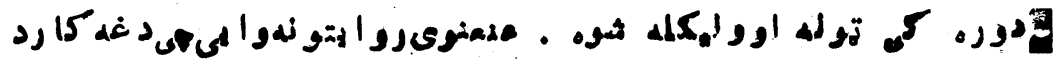

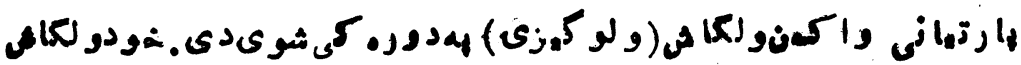

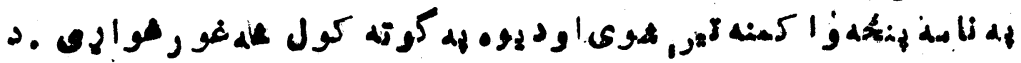

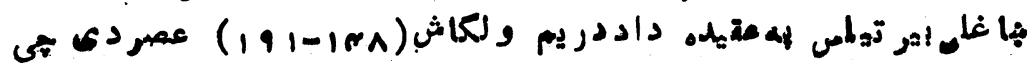

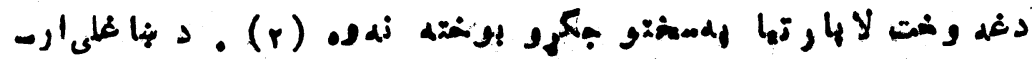

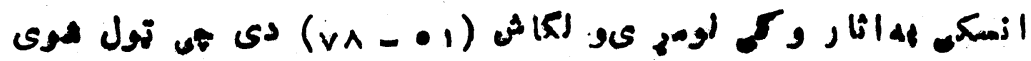

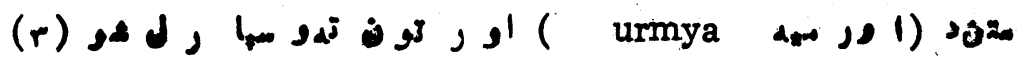

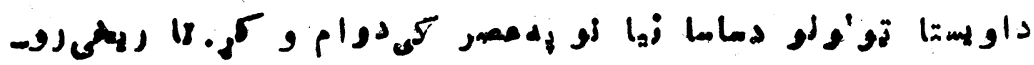

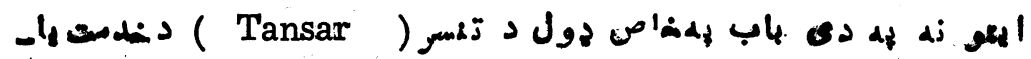

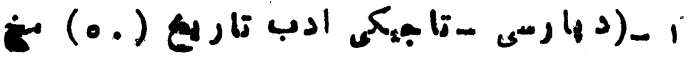

$$
\begin{aligned}
& \Rightarrow(r v)>n
\end{aligned}
$$

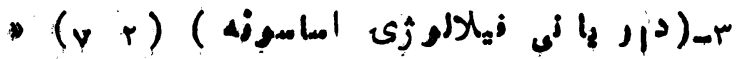


$-119-$

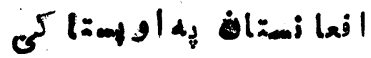

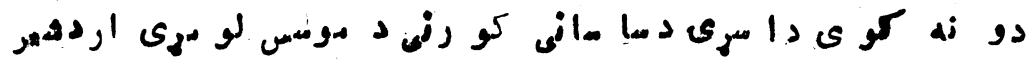

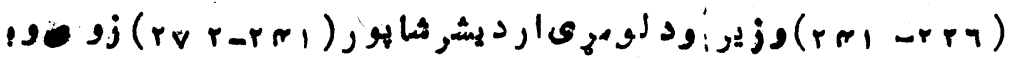

- د.

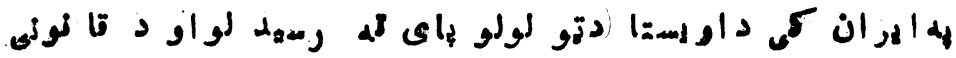

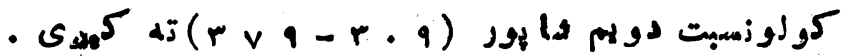

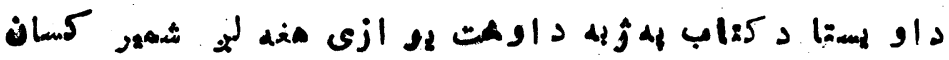

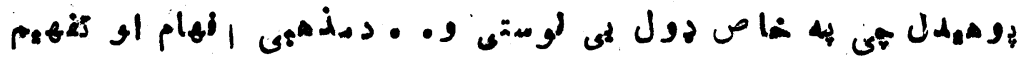

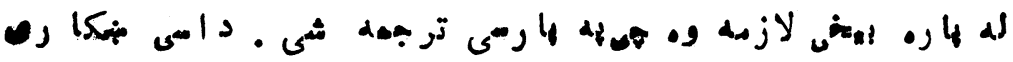

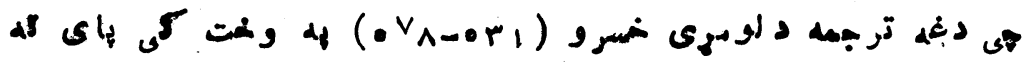

-

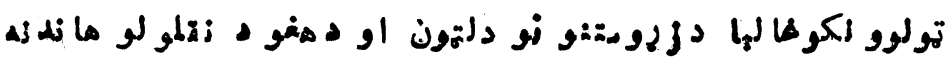

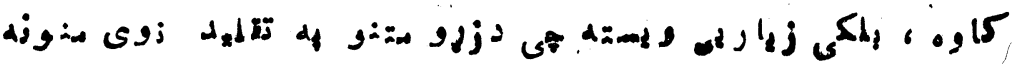

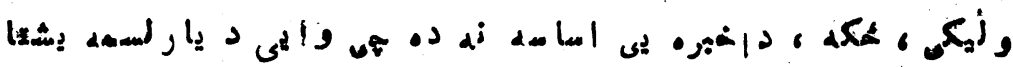

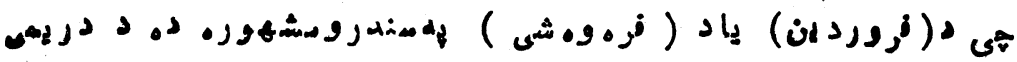

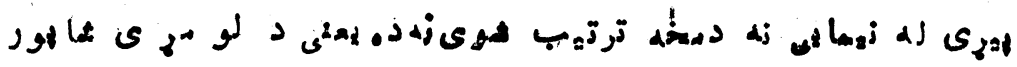

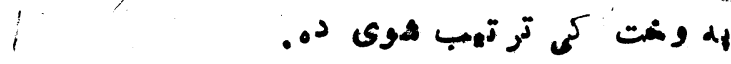

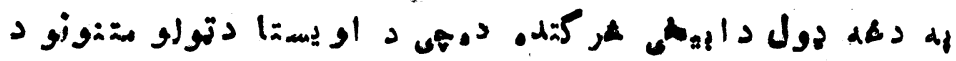

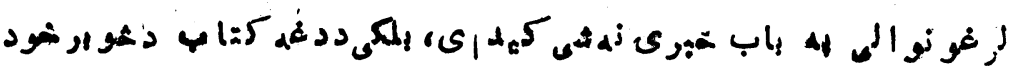

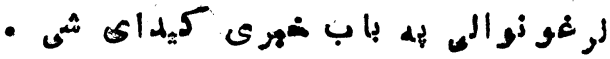

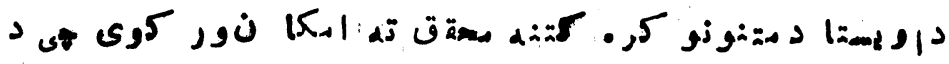

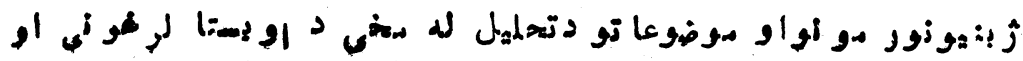

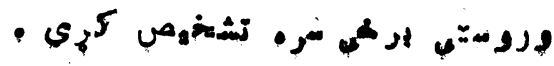




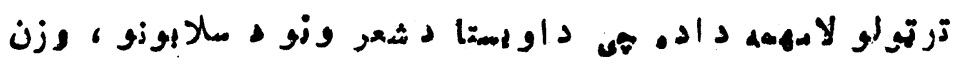

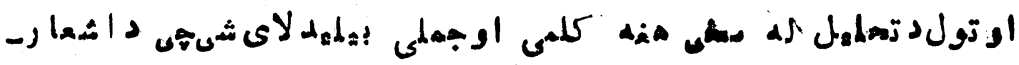

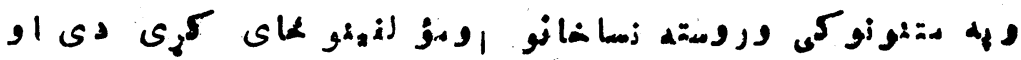

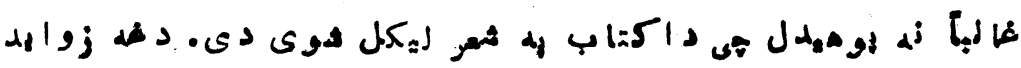

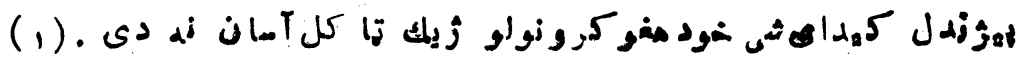

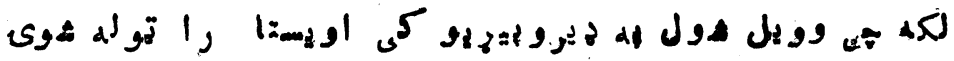

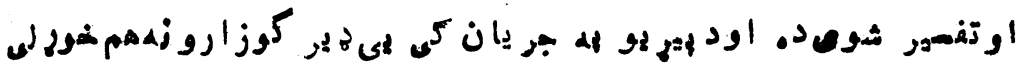

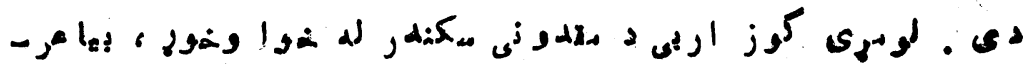

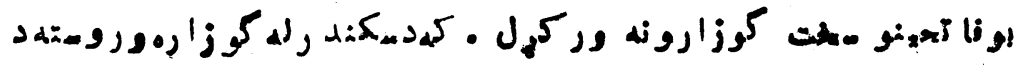

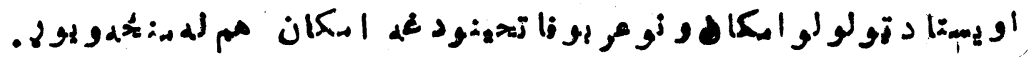

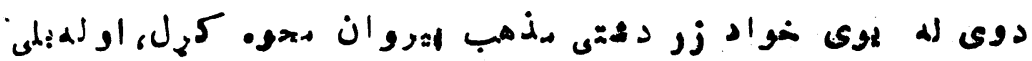

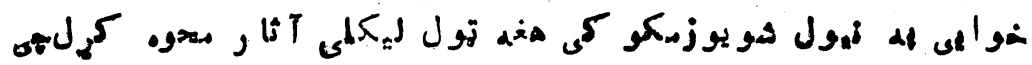

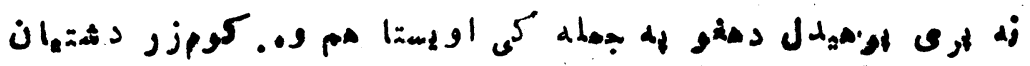

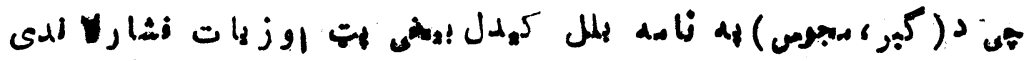

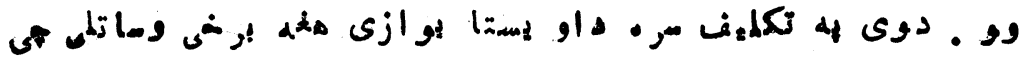

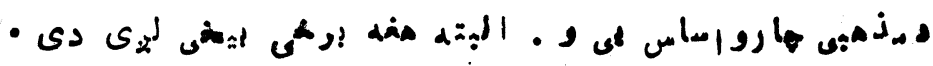

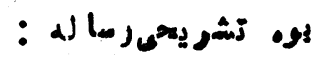

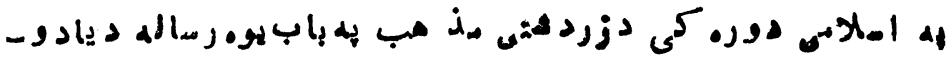

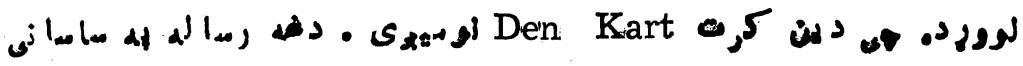

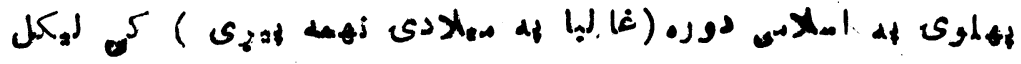

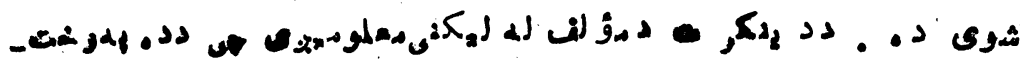

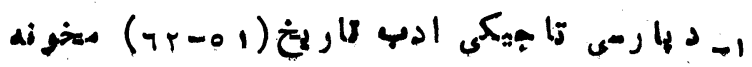


$-1 \times 1-$

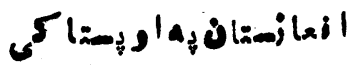

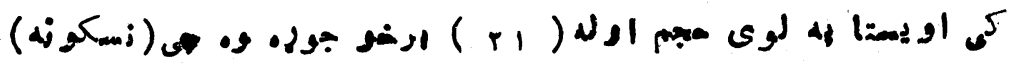
زو زa

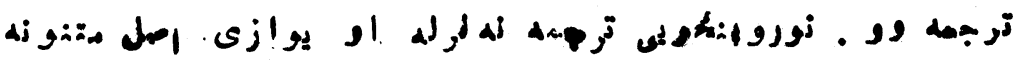
ور كمى ثما هل وو زلهرو (1,

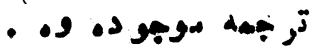

دد

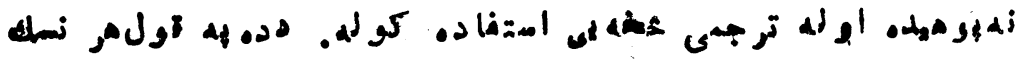

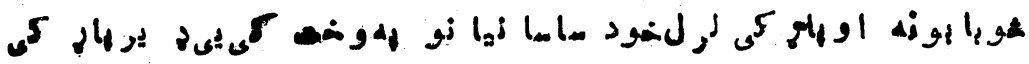

- golli asiand

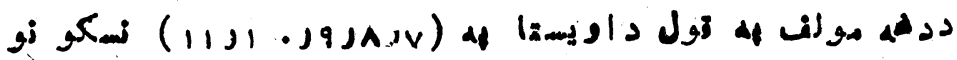

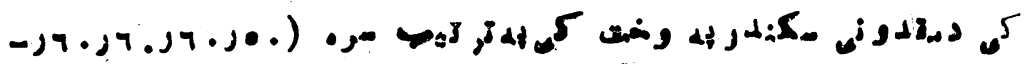

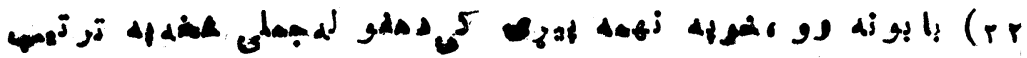

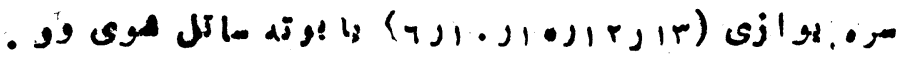
دد

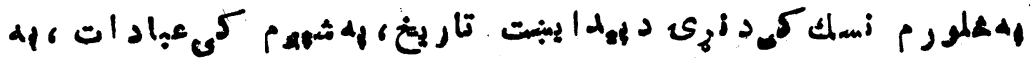

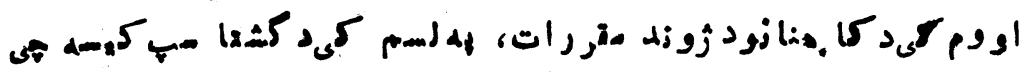

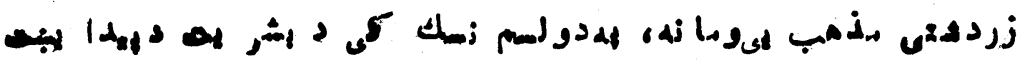

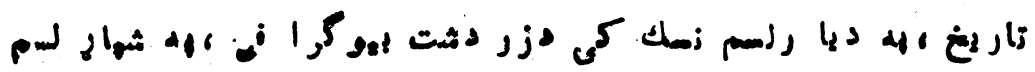

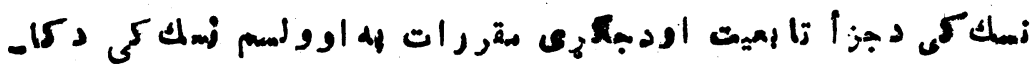

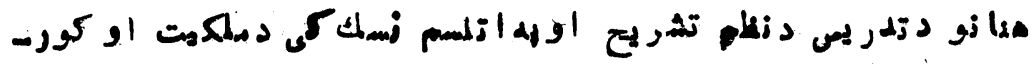

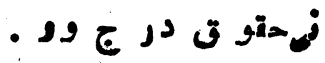

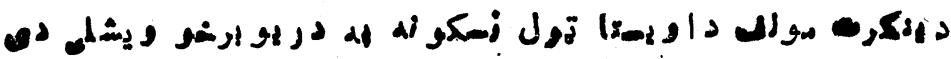




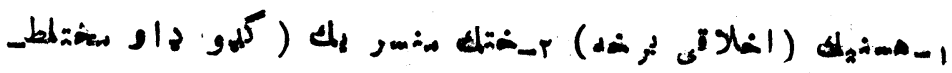

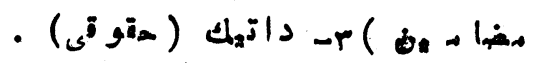

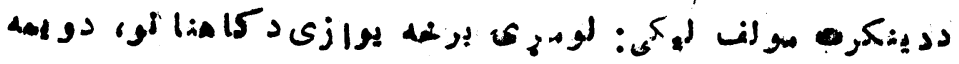

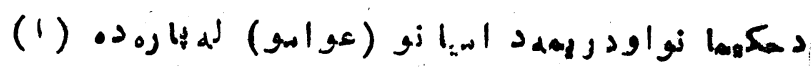

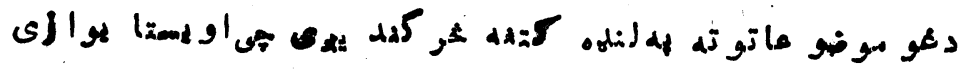

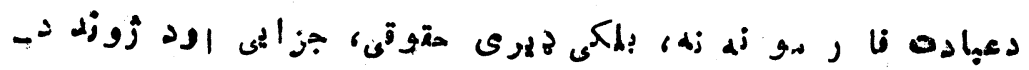

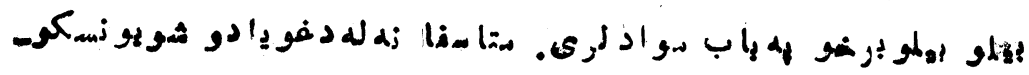

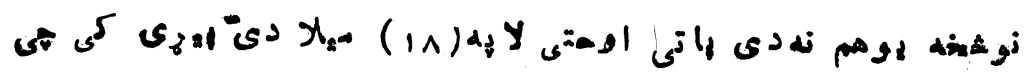

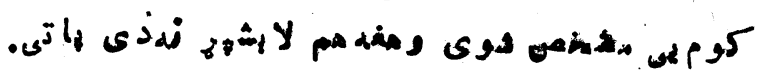

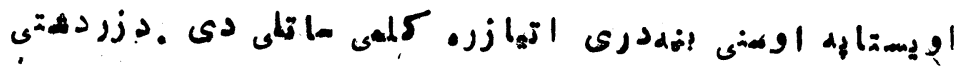

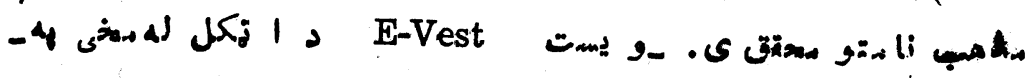

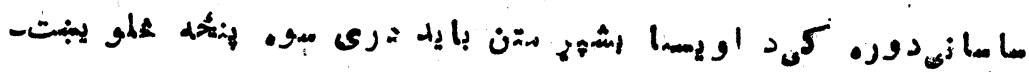

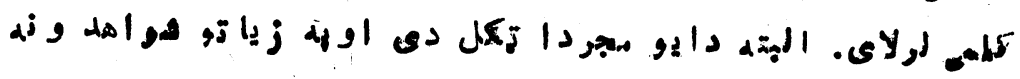

(r) .

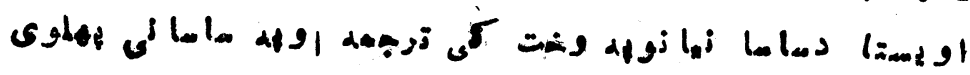

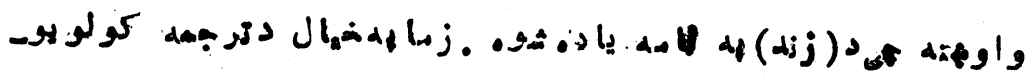

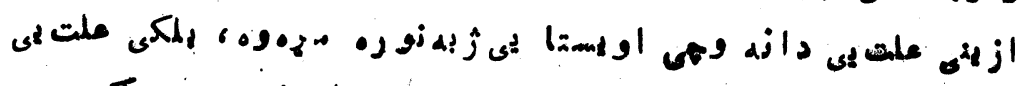

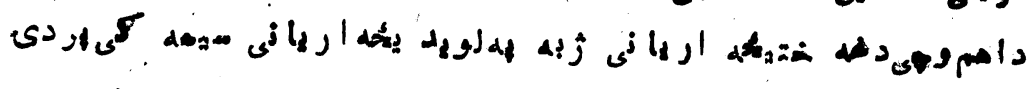

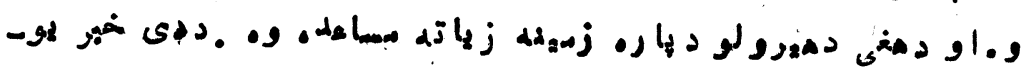

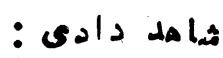

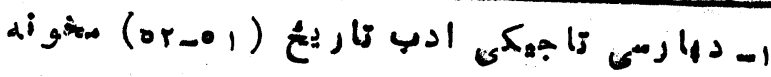

$$
\begin{aligned}
& \text { (or) }(0,-r
\end{aligned}
$$




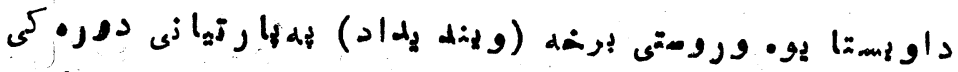

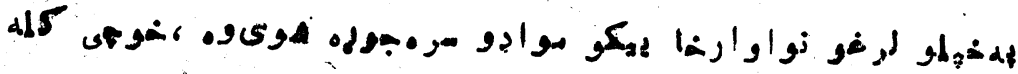

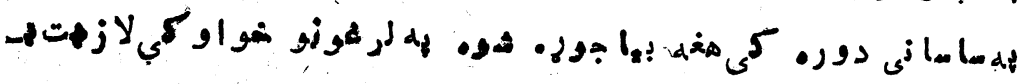

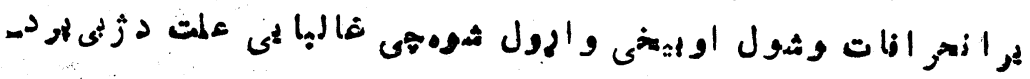

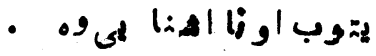

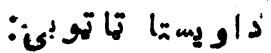

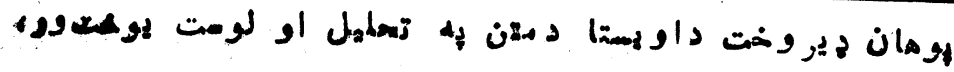

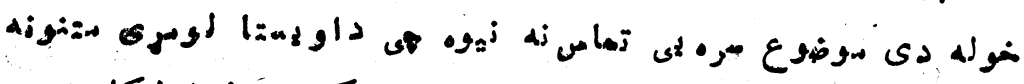

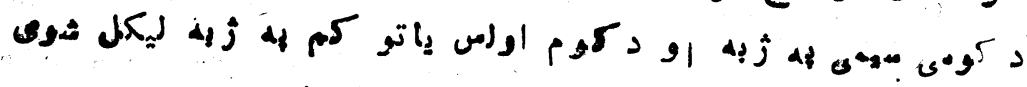

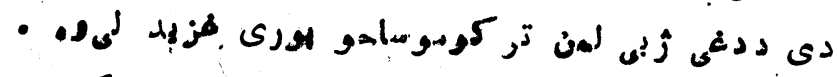

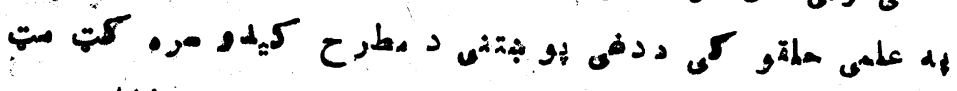

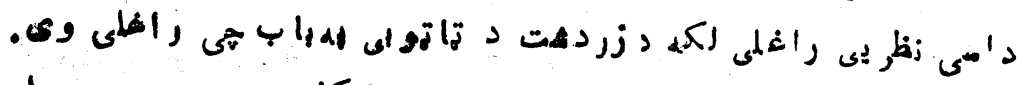

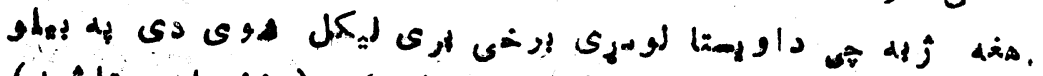

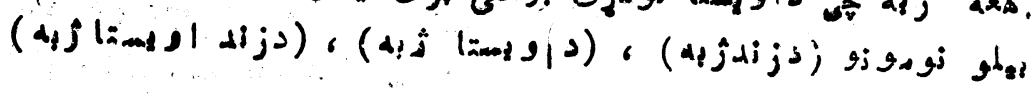

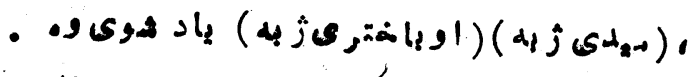

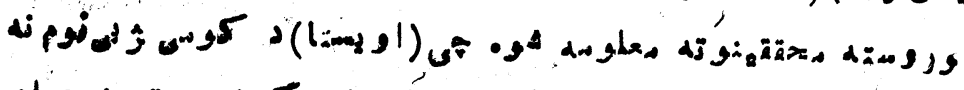

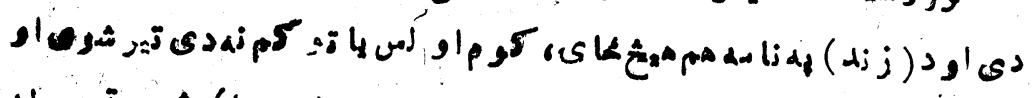

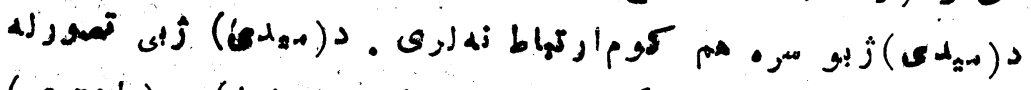

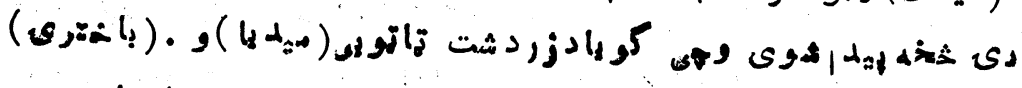

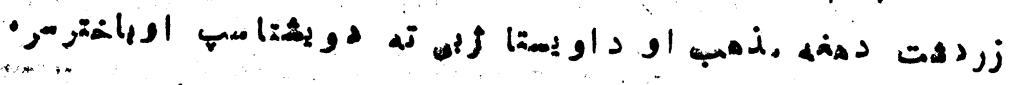

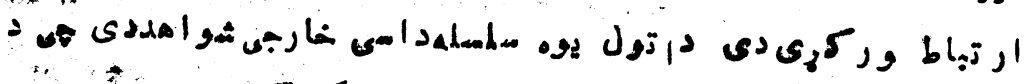

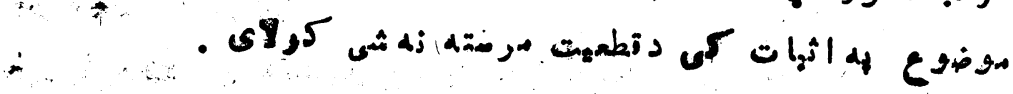




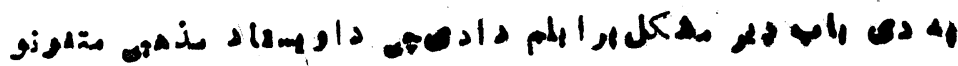

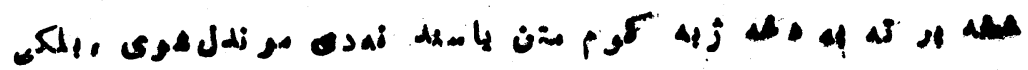

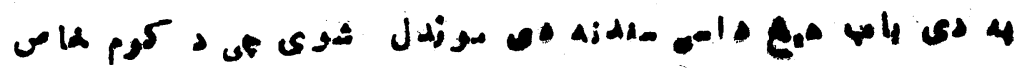
is

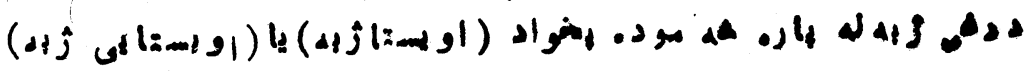
ats

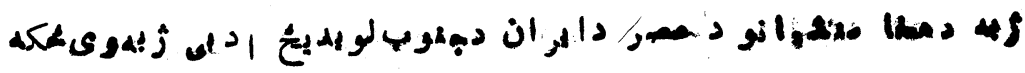

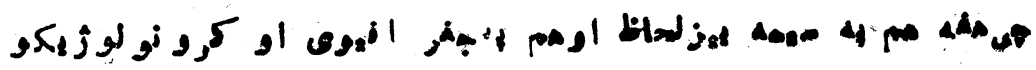

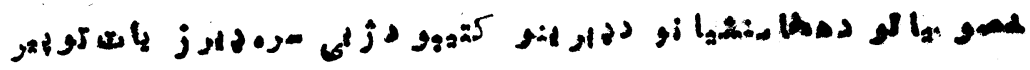

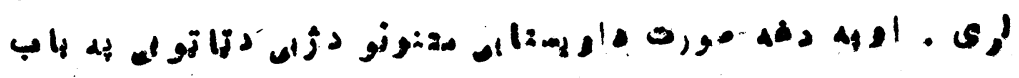

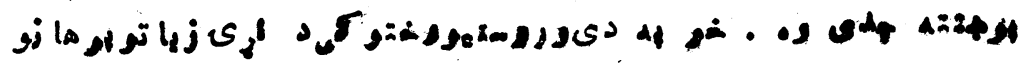
is

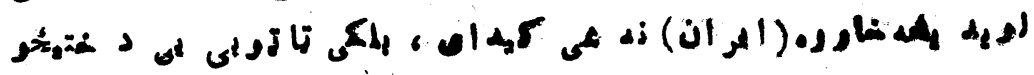

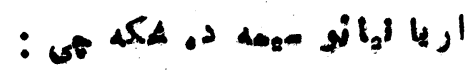

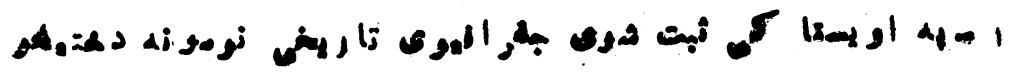

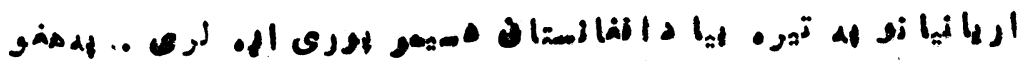

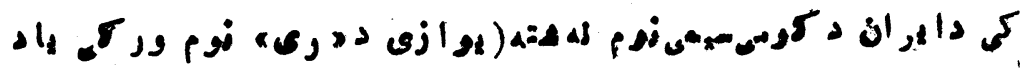
(u

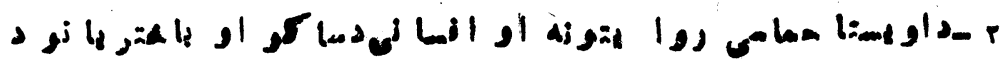

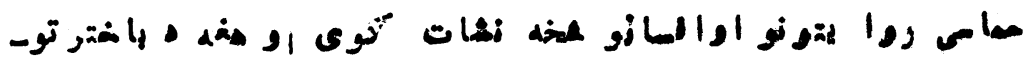

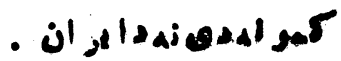

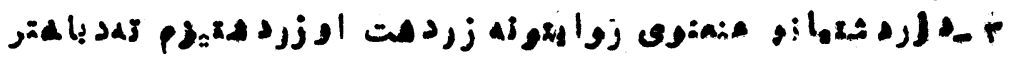


$-1+\bullet$

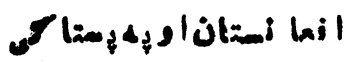

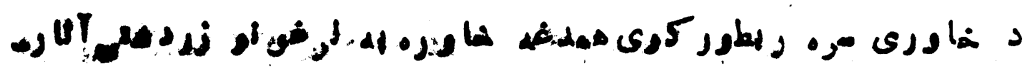

-

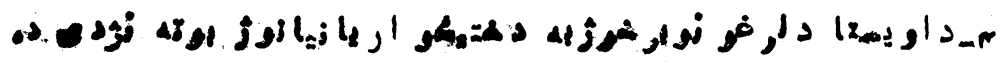

- زد الو إيد إئحو

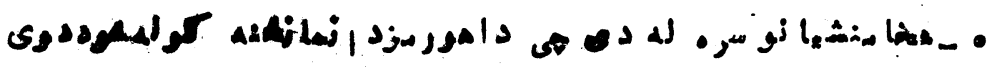

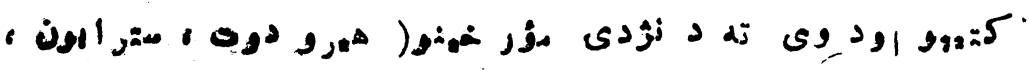

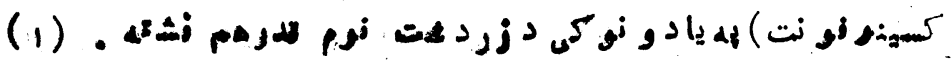

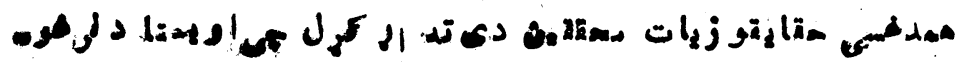

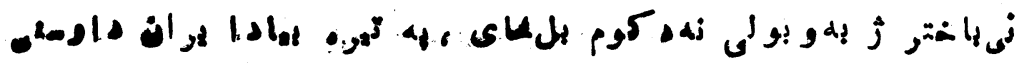

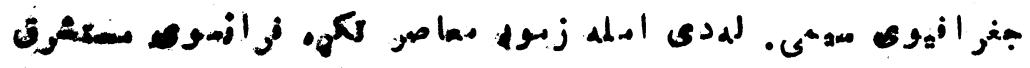

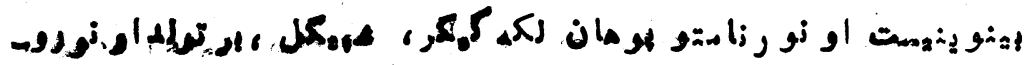

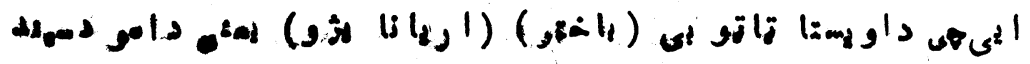

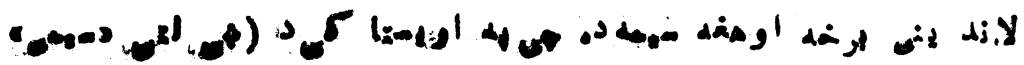

- sga osla distid (Vahyadatye

ل8:

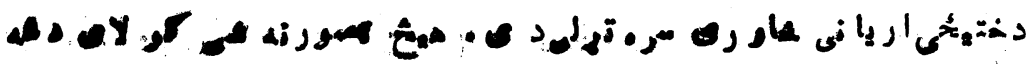

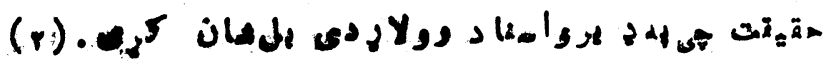

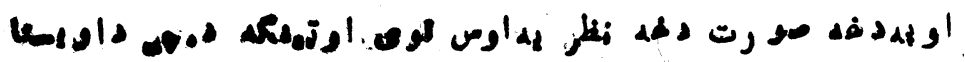

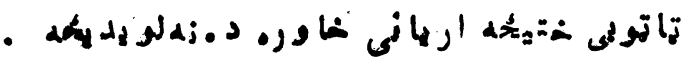

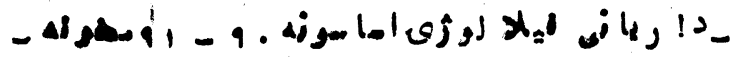

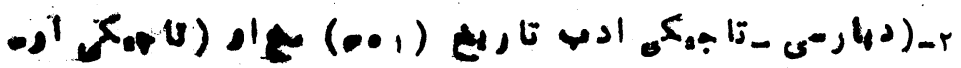

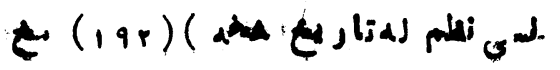


مز

$-187-$

هis

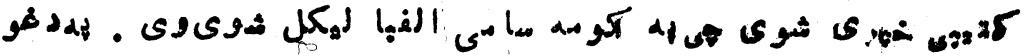
ها

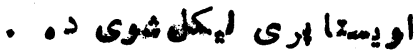

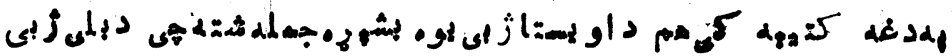

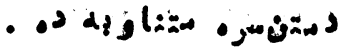

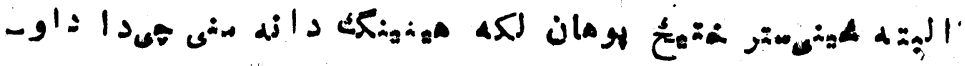

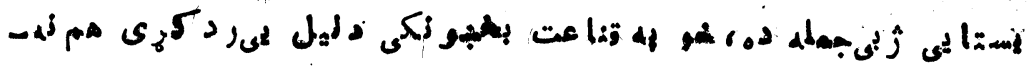

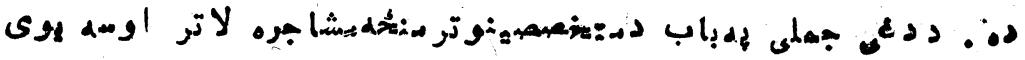

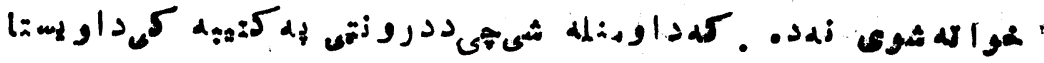

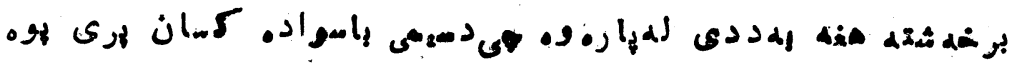

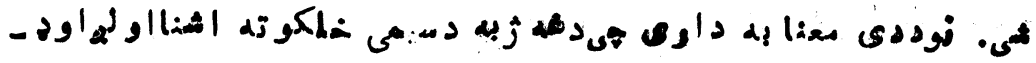

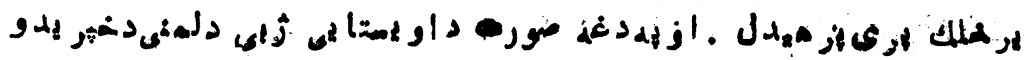

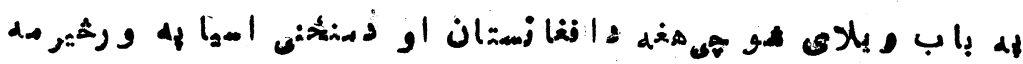

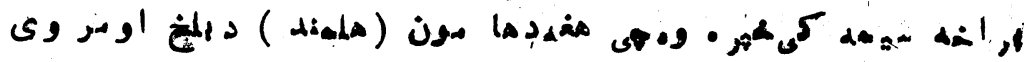

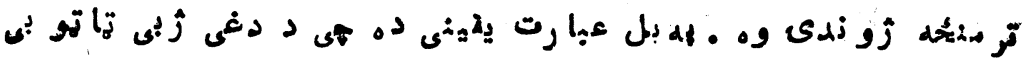

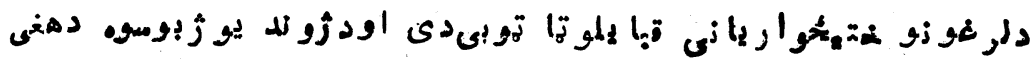

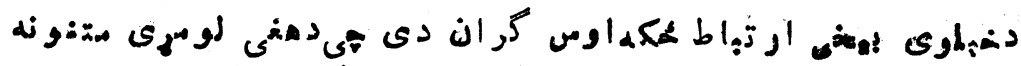

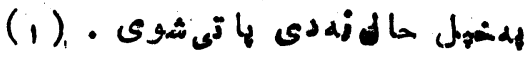

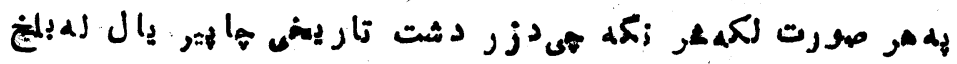

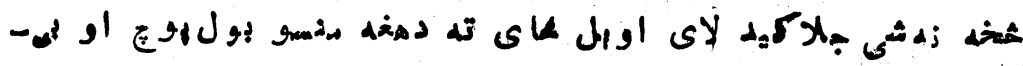

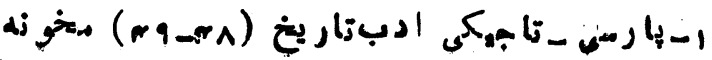


$-1 r v-$

S

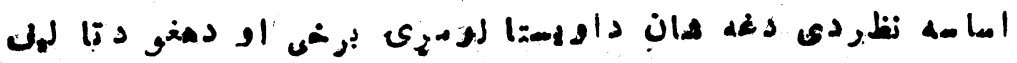

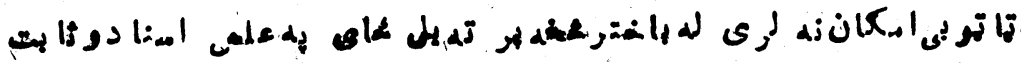

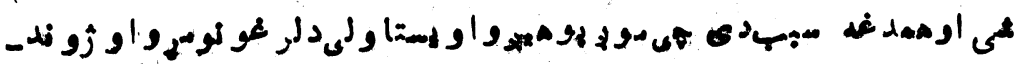

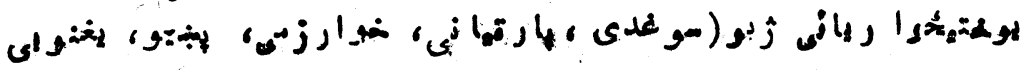

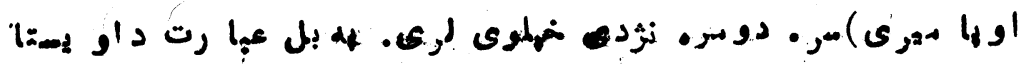

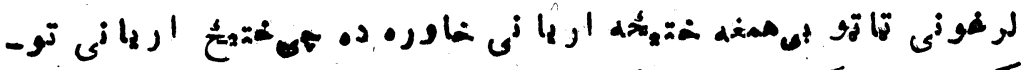

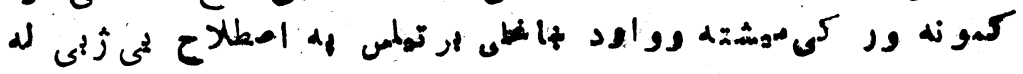

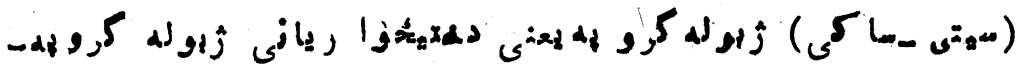

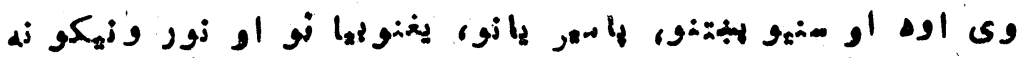

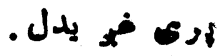

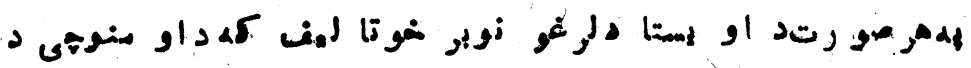

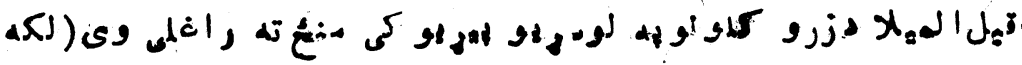

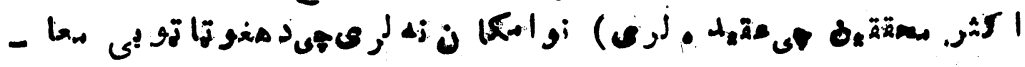

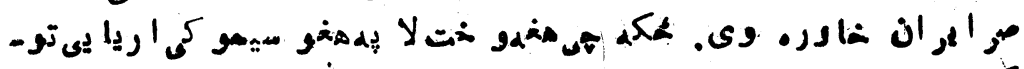

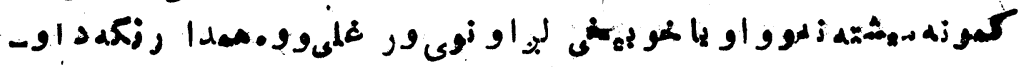

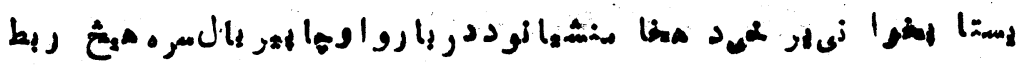

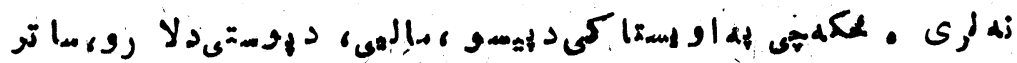

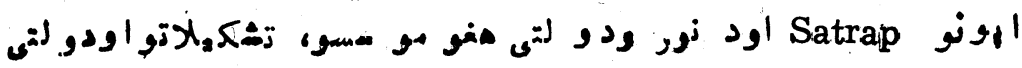

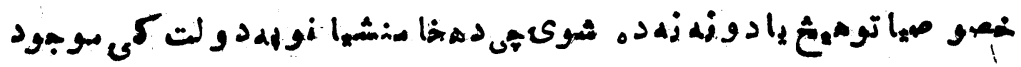

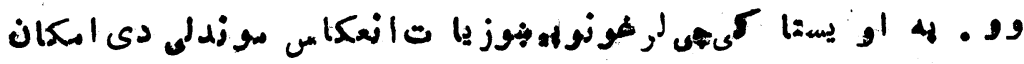

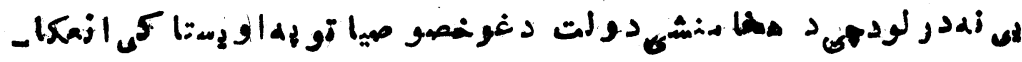

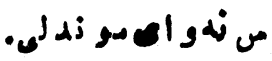

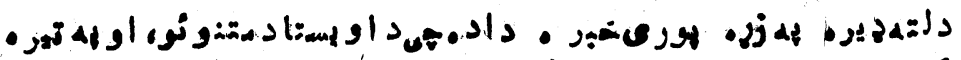

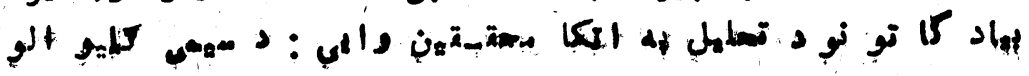


- . • •

IrA-

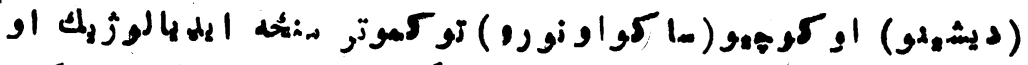

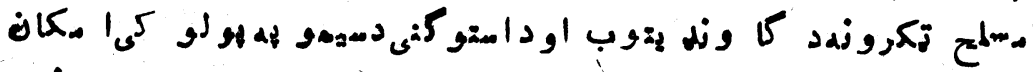

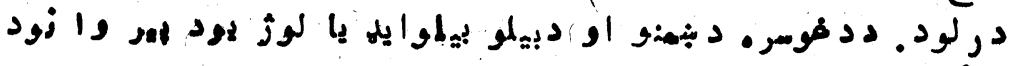

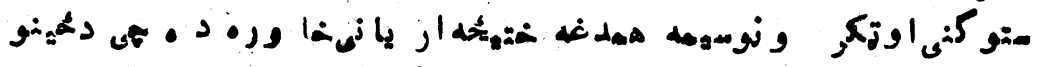

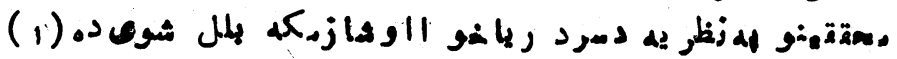

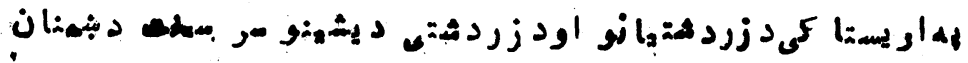

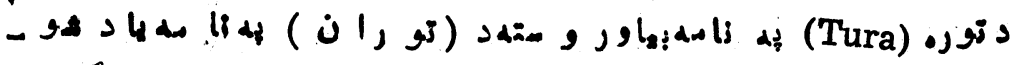

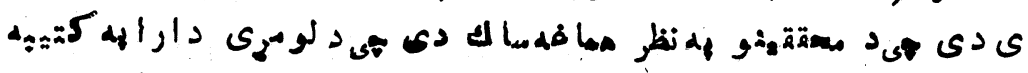

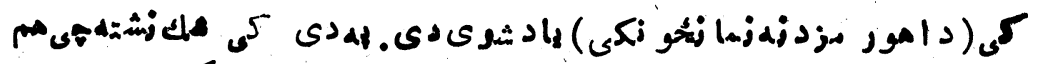

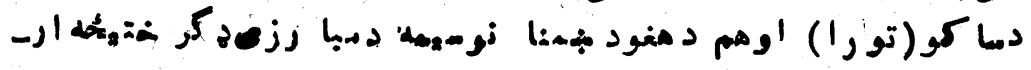

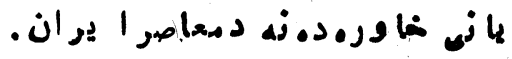

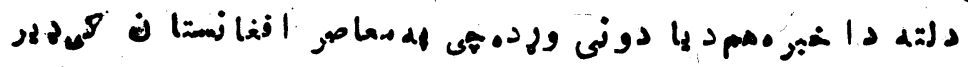

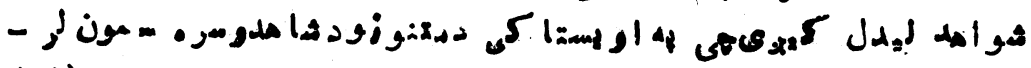

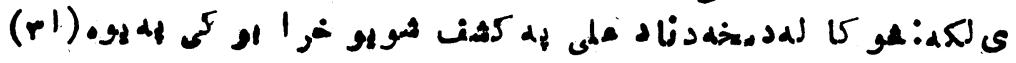

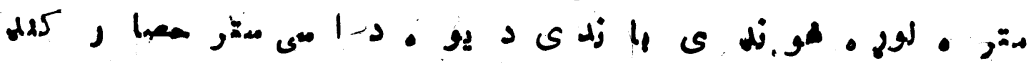

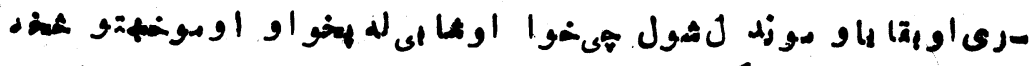

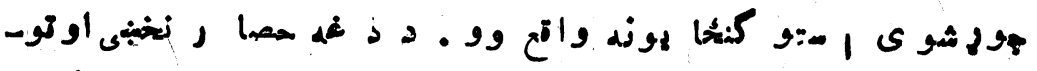

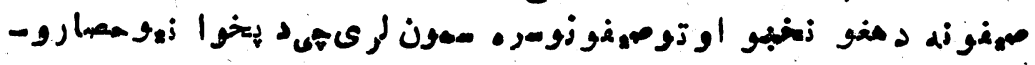

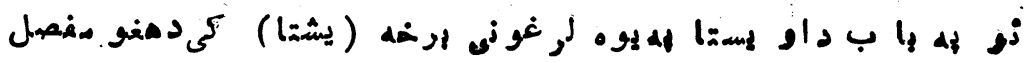

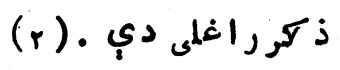

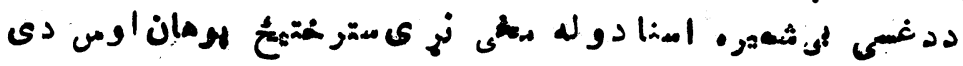

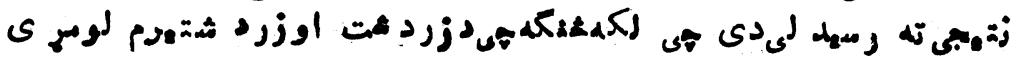

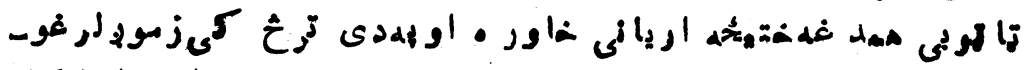

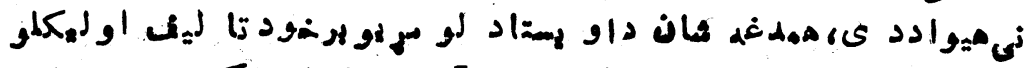

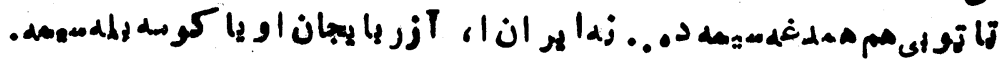

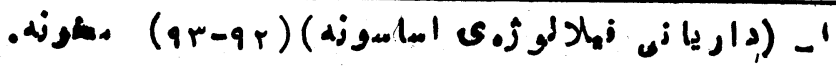

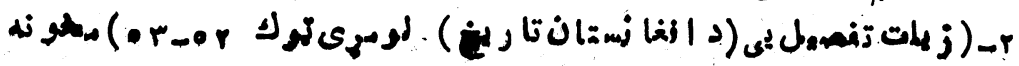




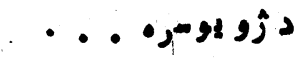

$-\operatorname{lit}$.

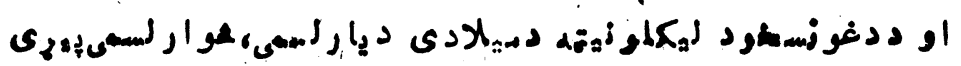

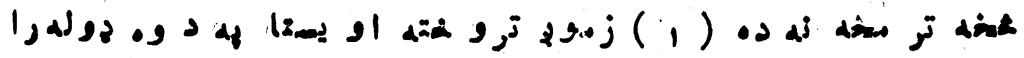

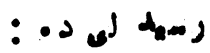

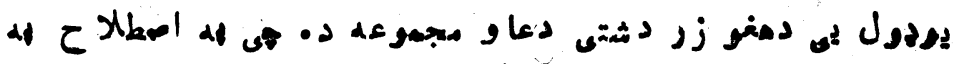

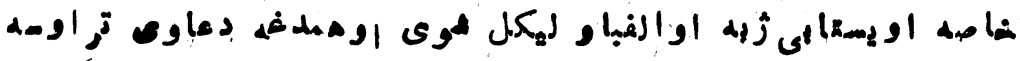

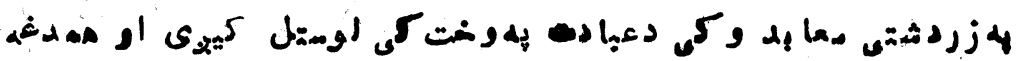

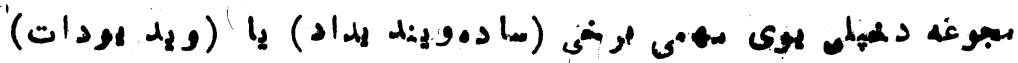

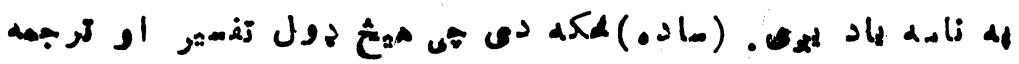

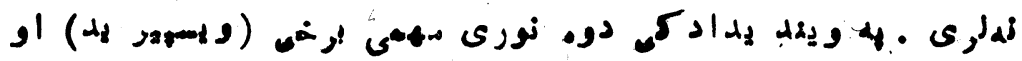

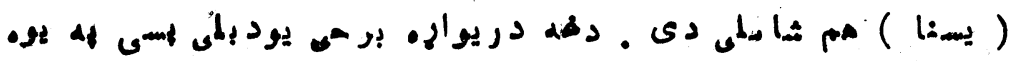

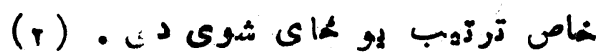

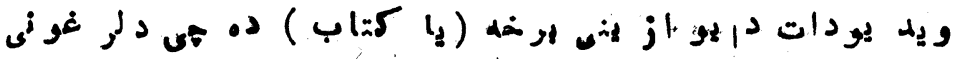

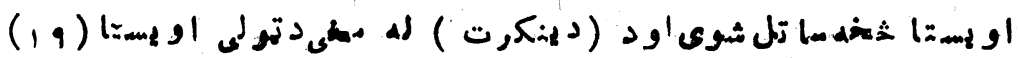

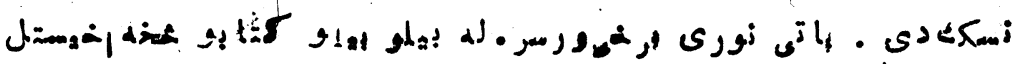

.

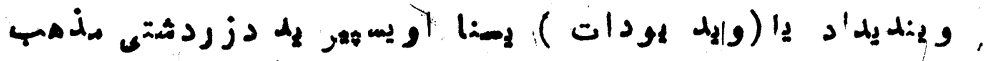

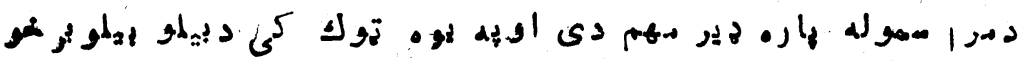

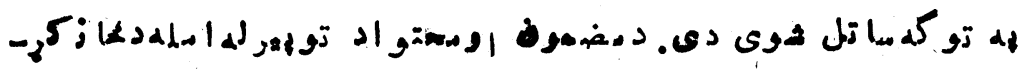

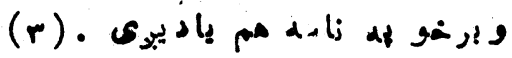

ا

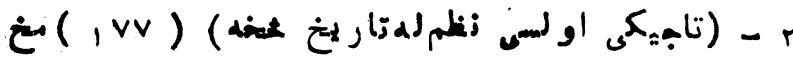
ro 
$-|r|-$

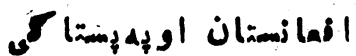

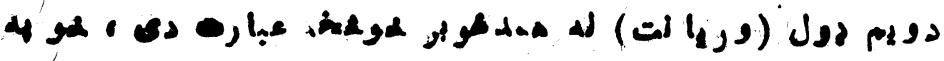

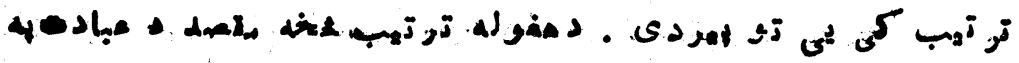

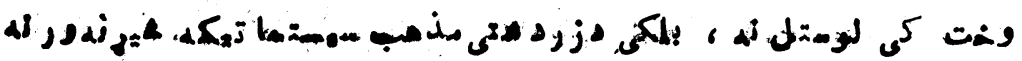

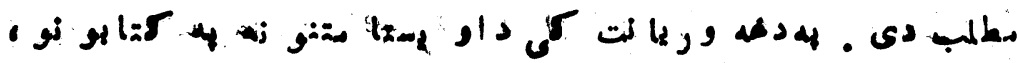

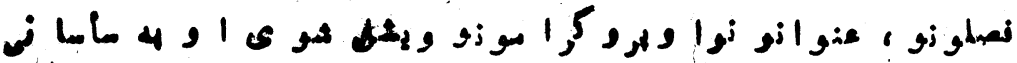

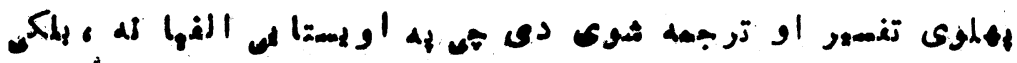

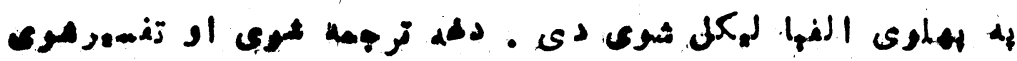

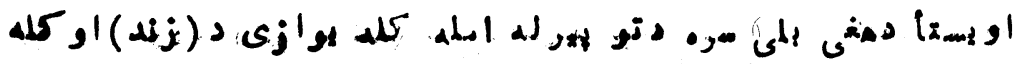
د) - إنه

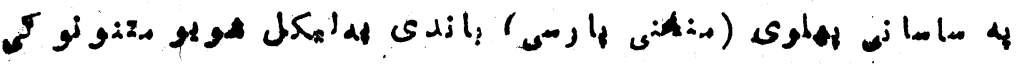

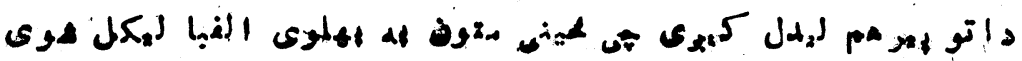

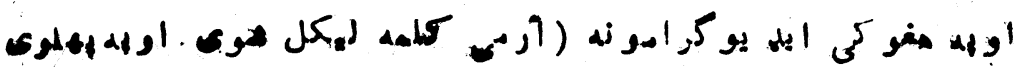

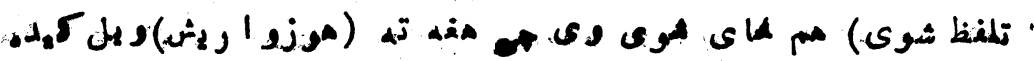

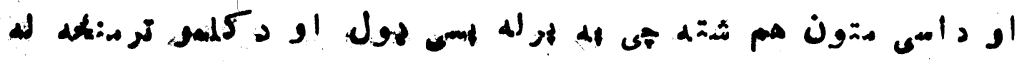

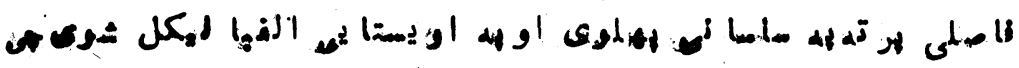

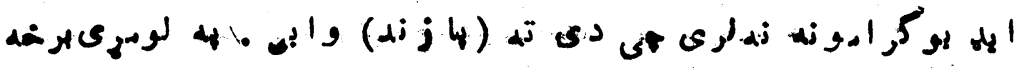
ك $5{ }^{5}$

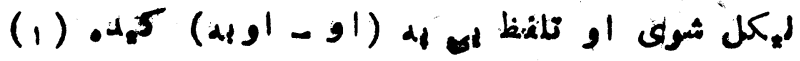

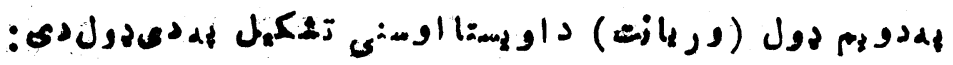

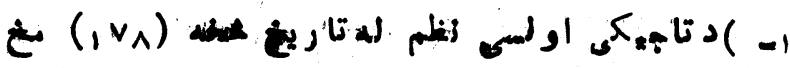




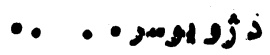

$-1 r r-$

:

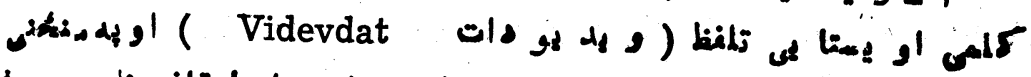

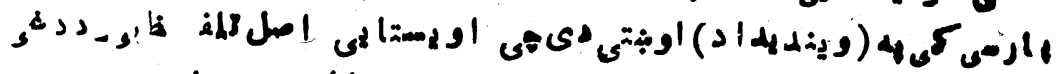

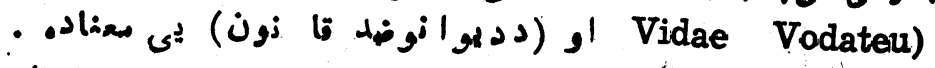

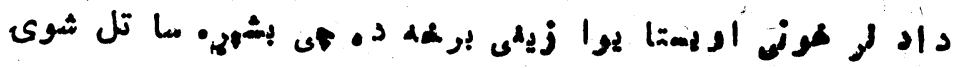

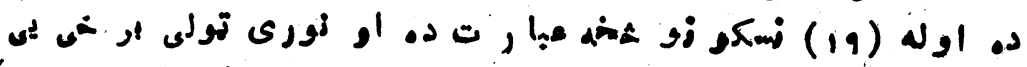

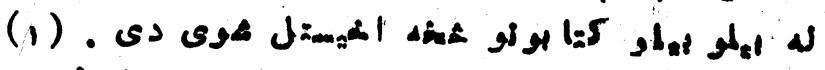

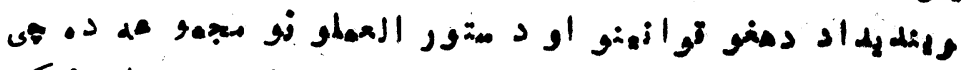

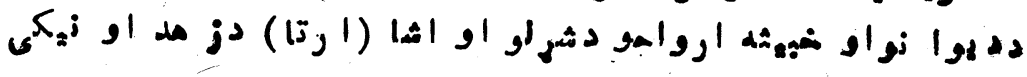

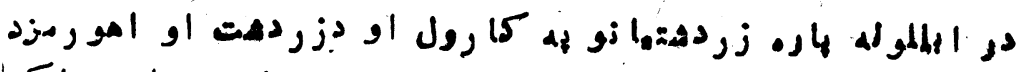

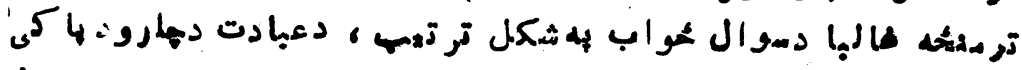

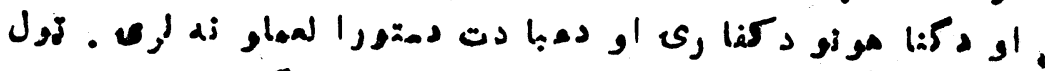

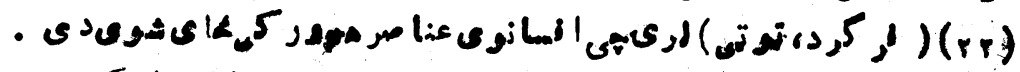

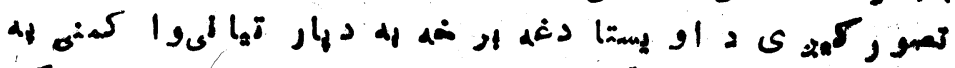

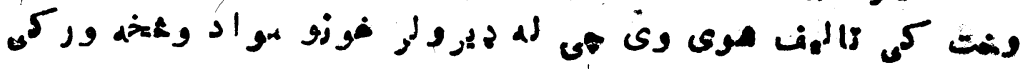

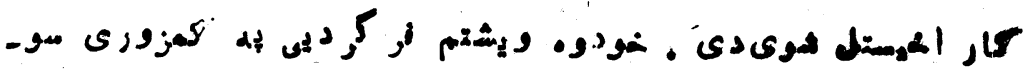

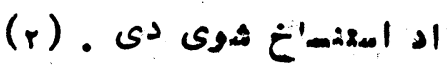

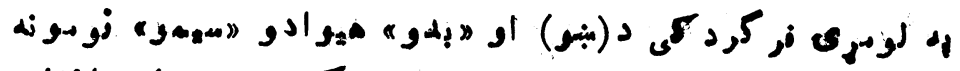

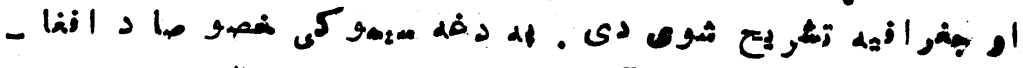

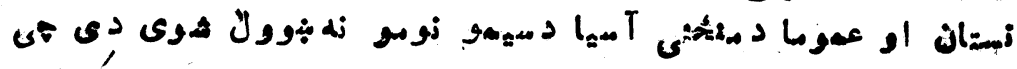

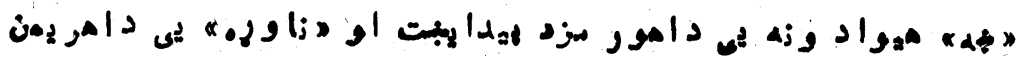

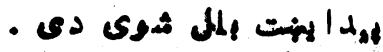

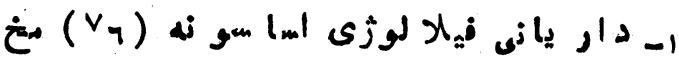

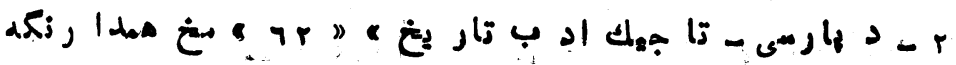

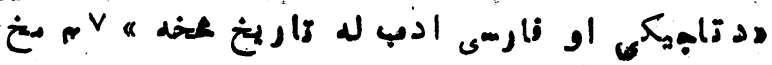


- Irr

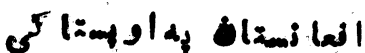

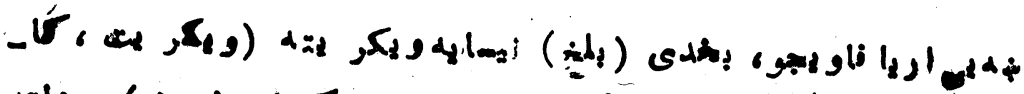

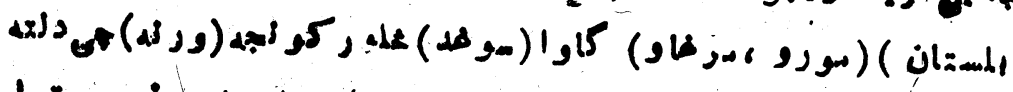

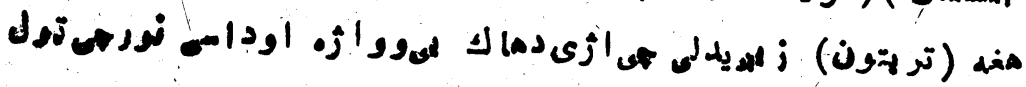

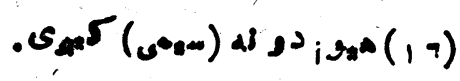

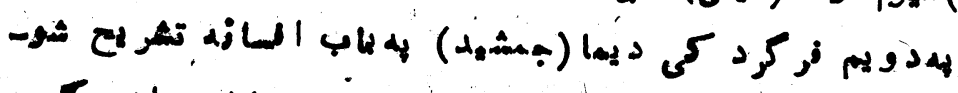

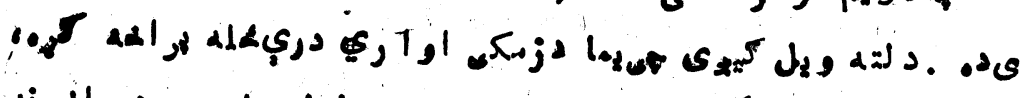

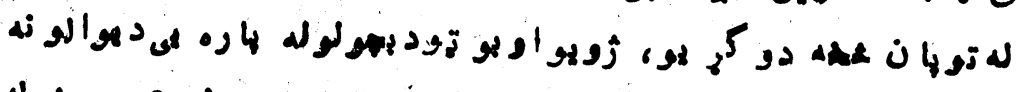

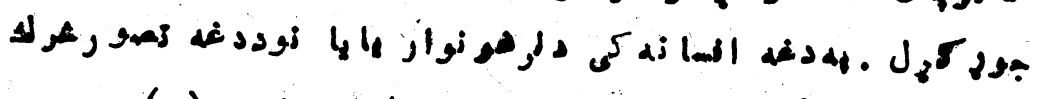

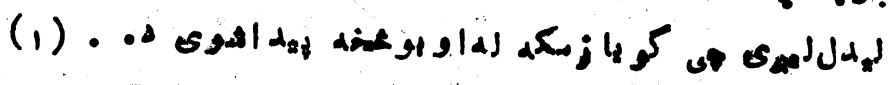

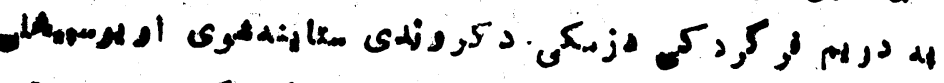

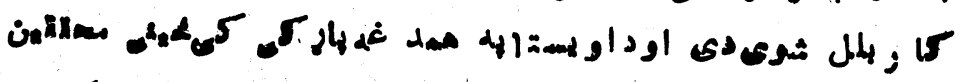

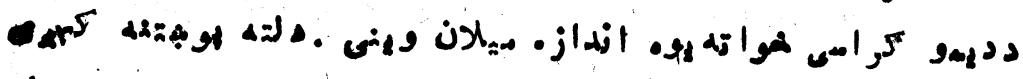

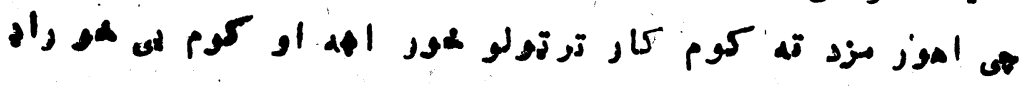
.

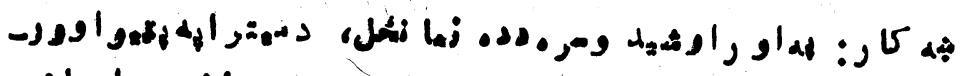

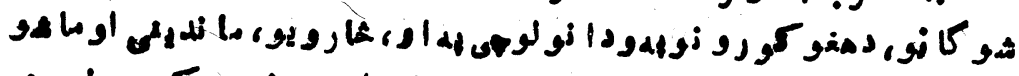

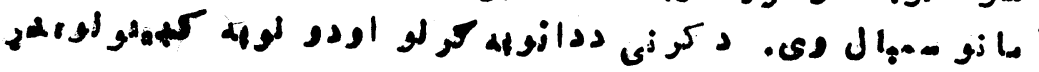

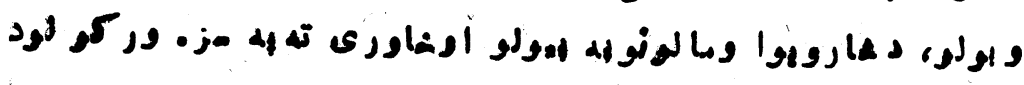
.

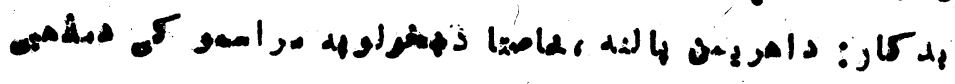

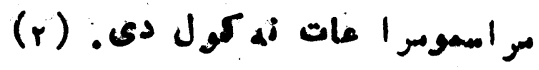

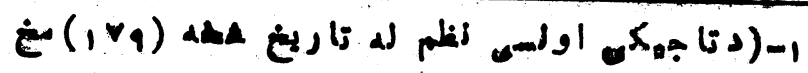
$\left(1_{\Lambda_{0}}\right) \geqslant, \cdots, y_{-r}$ 
كردئ

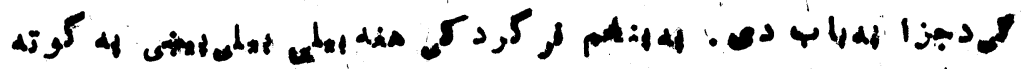
موى دىمي د

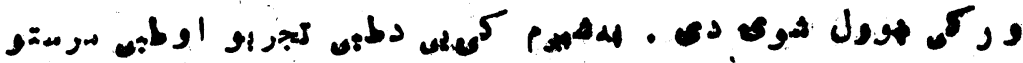

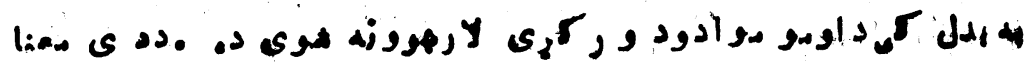

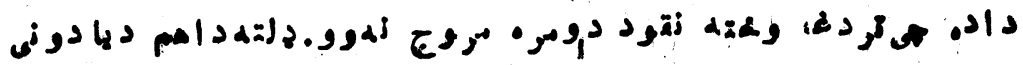

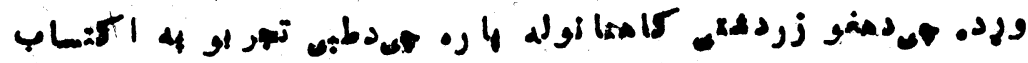

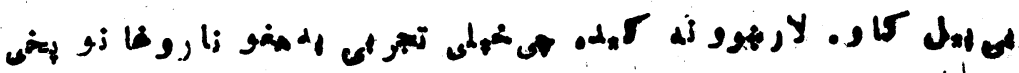

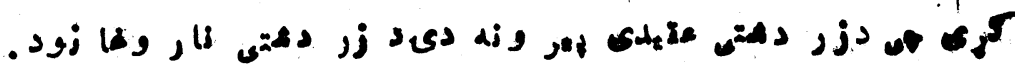

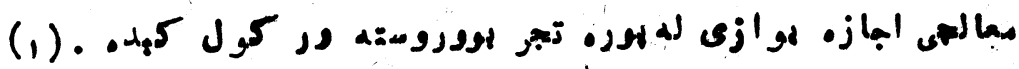

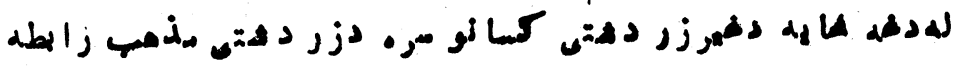

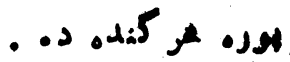

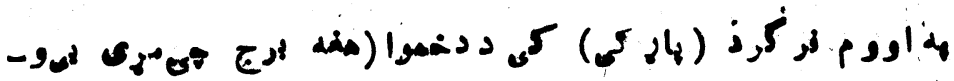

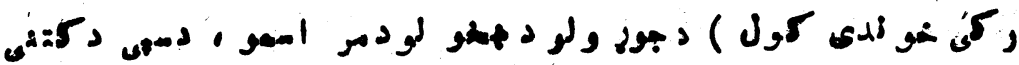

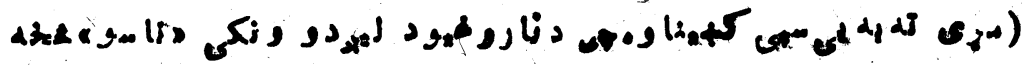

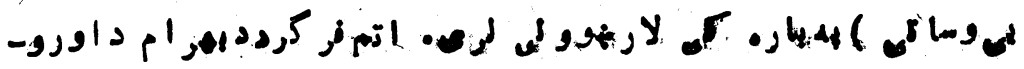

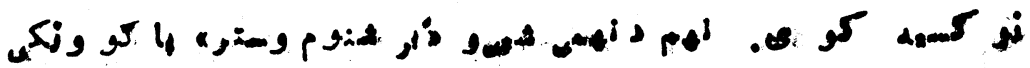

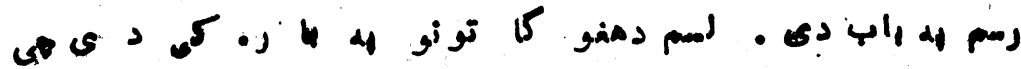

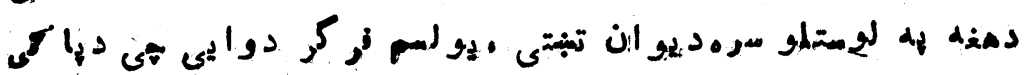

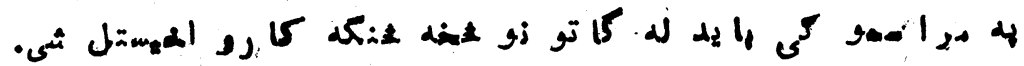

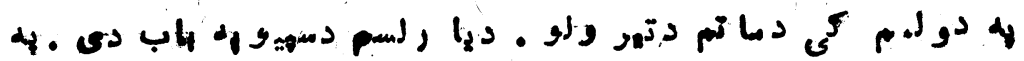

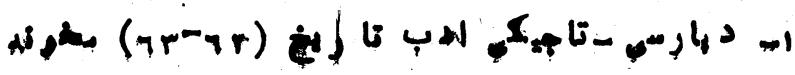




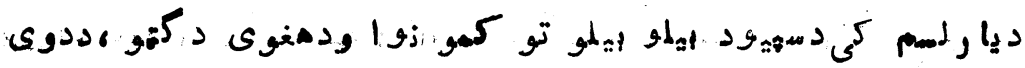

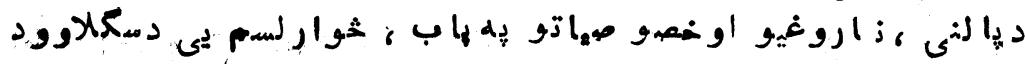

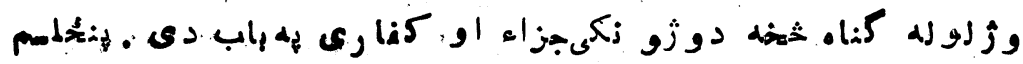

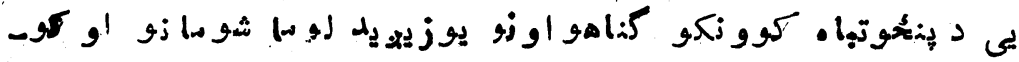

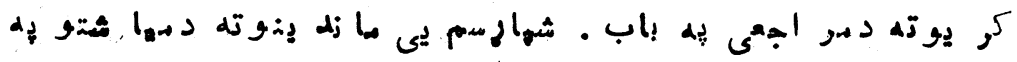

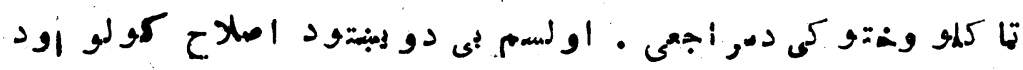

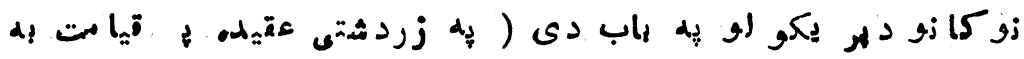

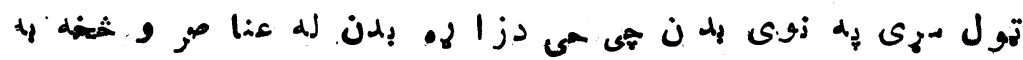

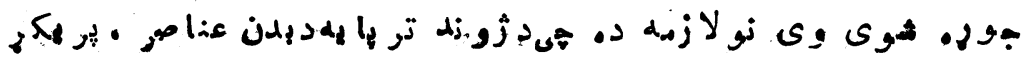

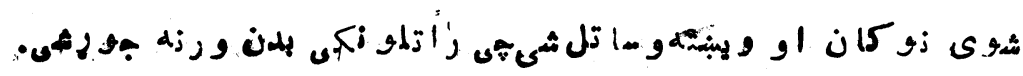

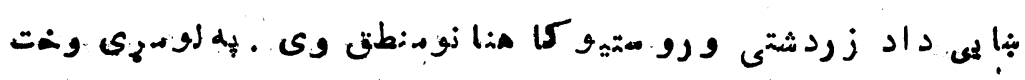

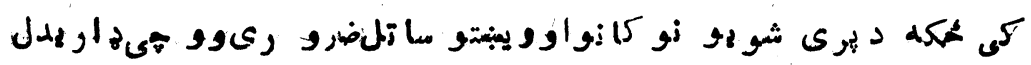

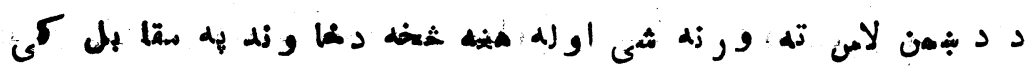

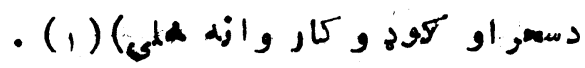

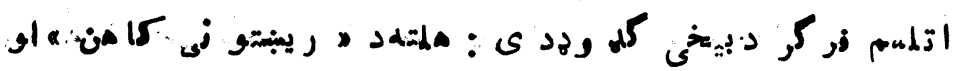

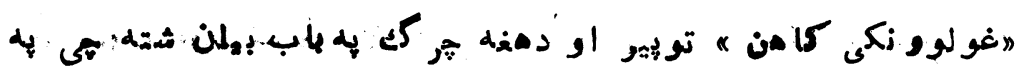

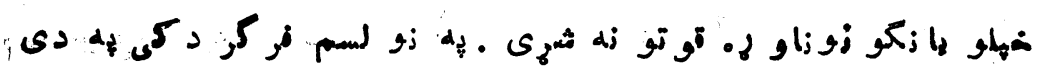

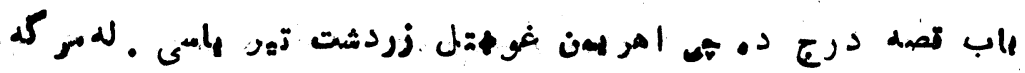

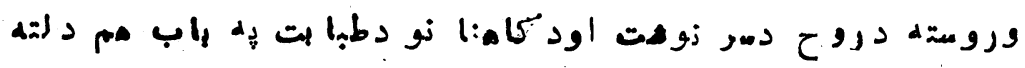

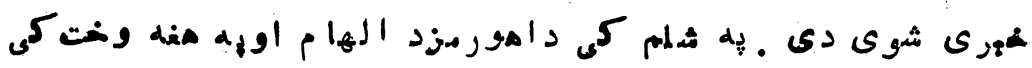

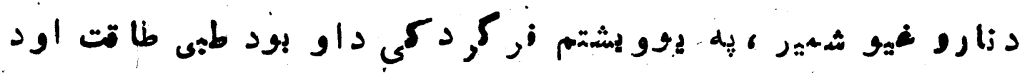

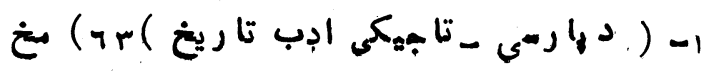




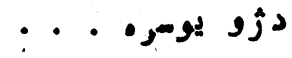

- irg

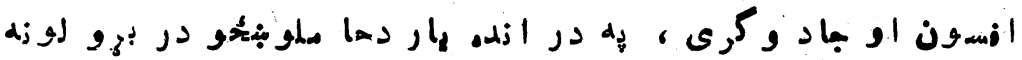

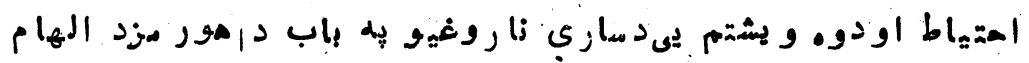

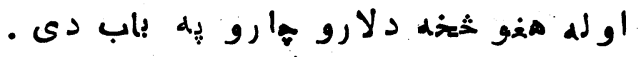

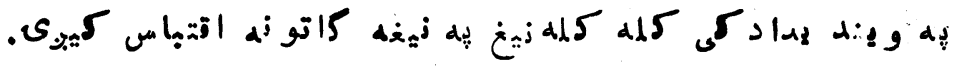

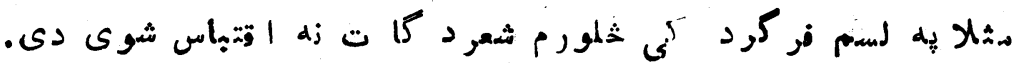

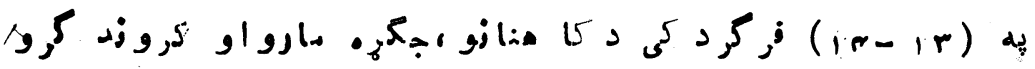

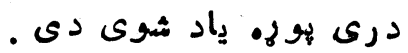

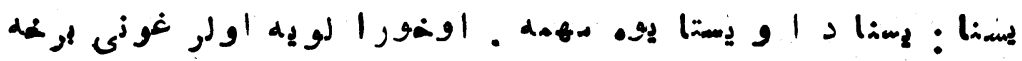

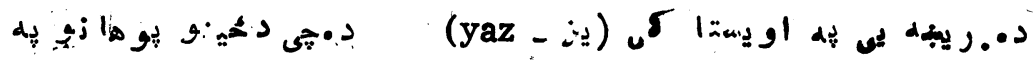

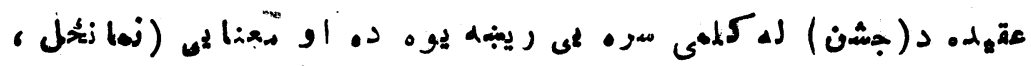

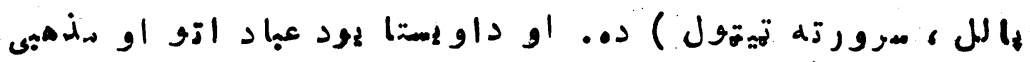

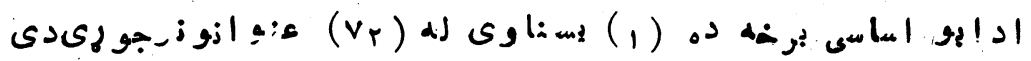

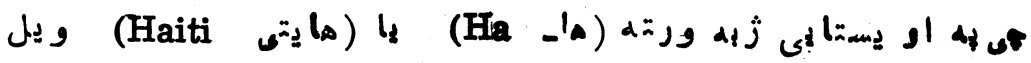

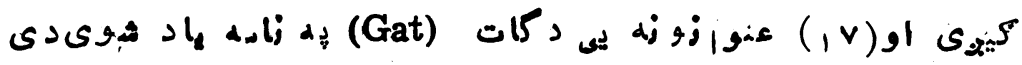
هیىA

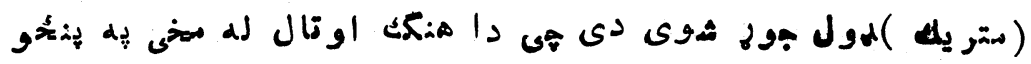

•

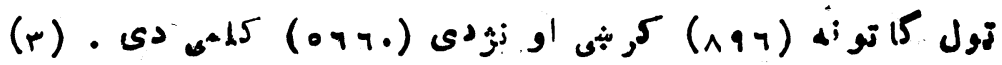

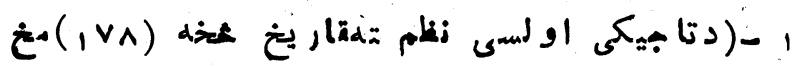

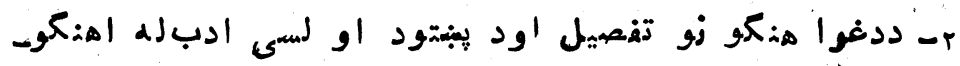

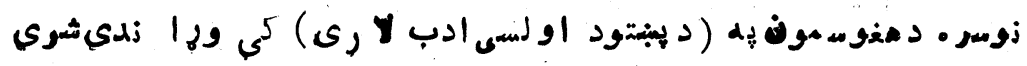

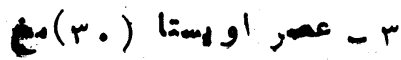


-irve

ا

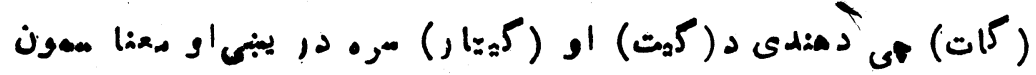

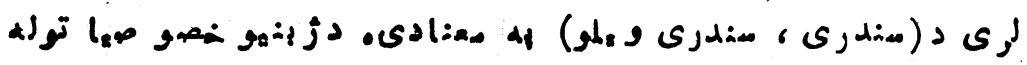

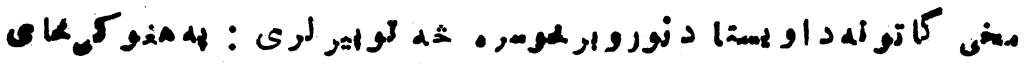

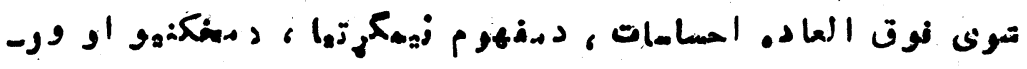

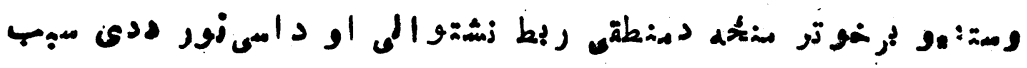

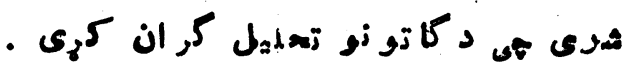

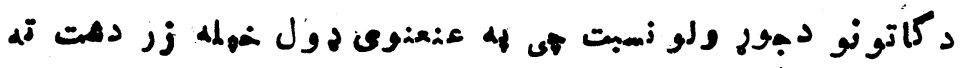

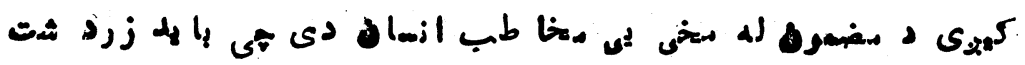

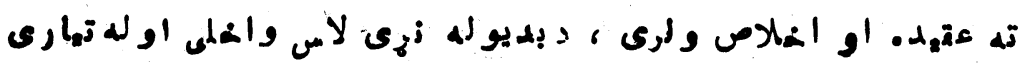

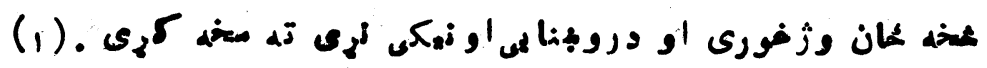

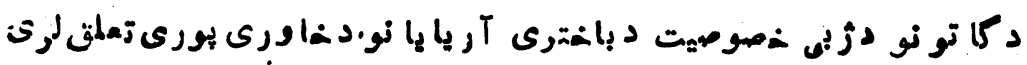

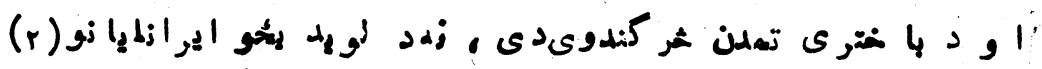

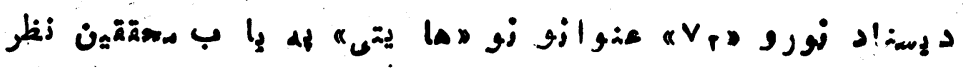

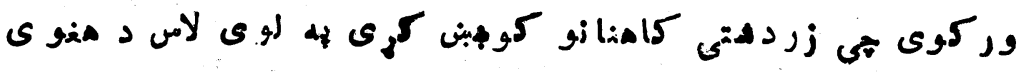

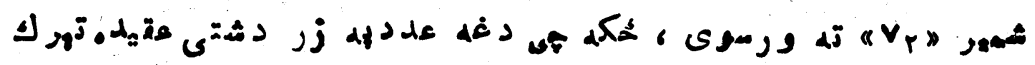

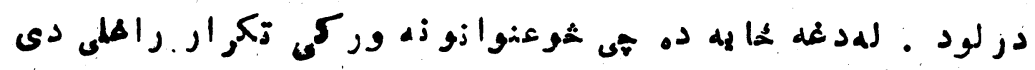

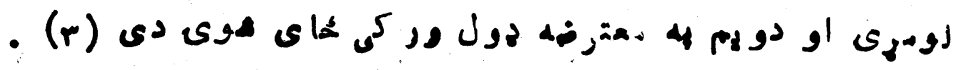

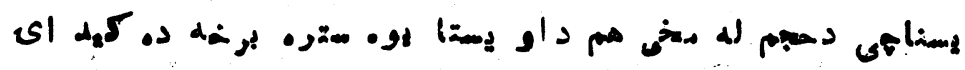

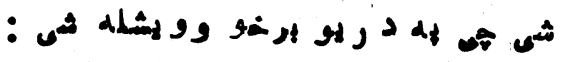

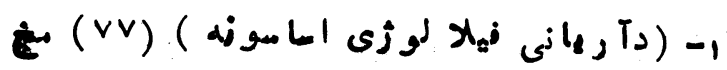

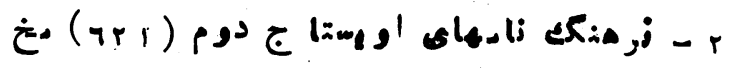

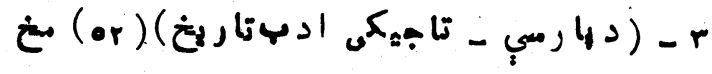


-.

$-\operatorname{lr} \wedge-$

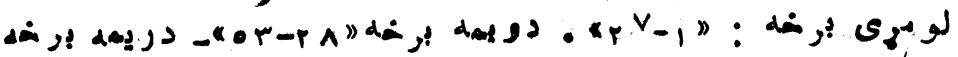

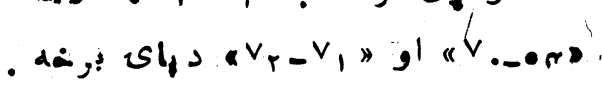

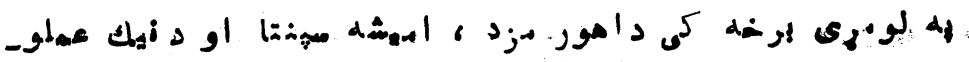

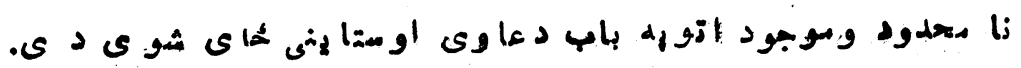

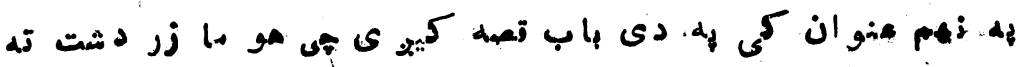

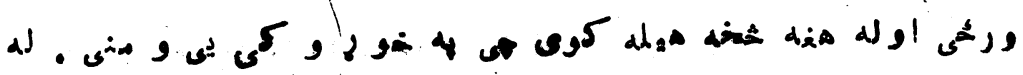

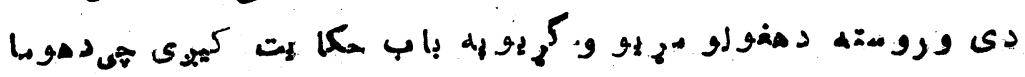

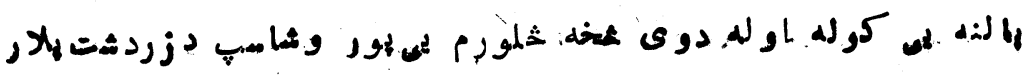

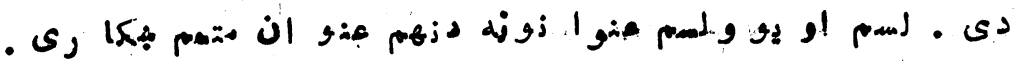

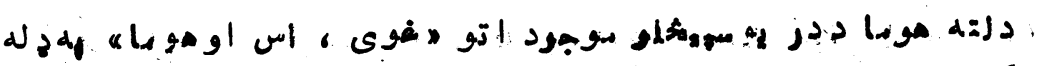

. ك.

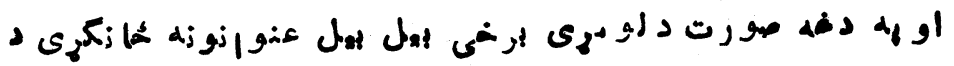

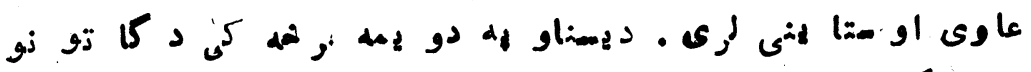
-

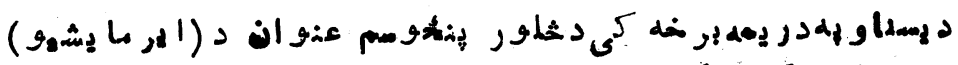
دعالd dispen

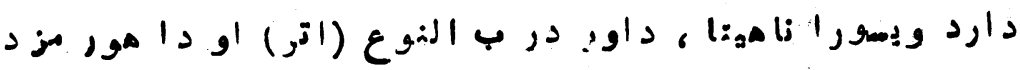

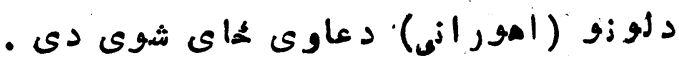

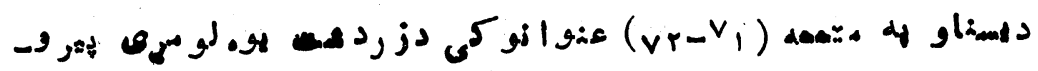

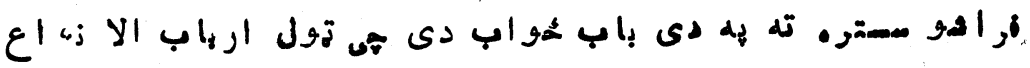

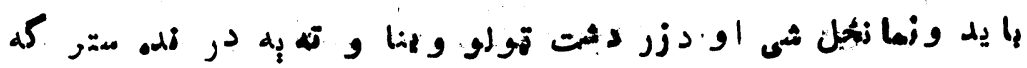

(1) $\cdot v^{2}$

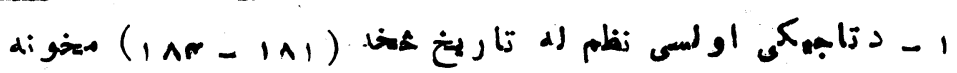


$-1 P q-$

1. I

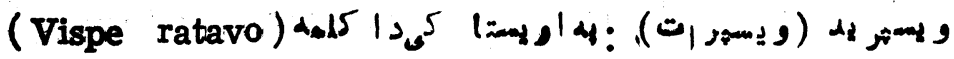

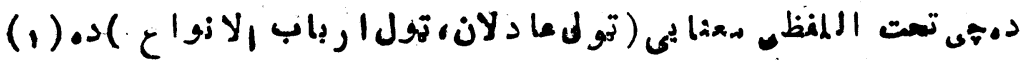

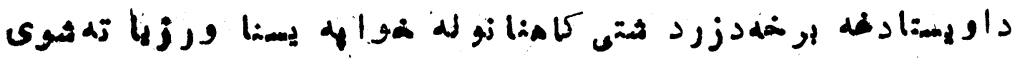

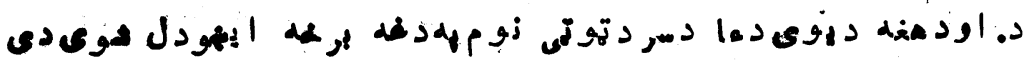

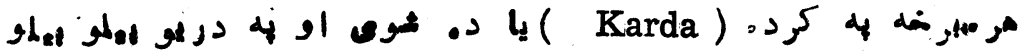

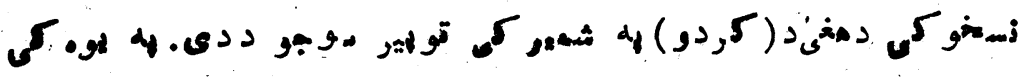

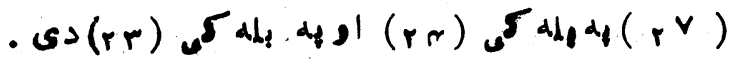

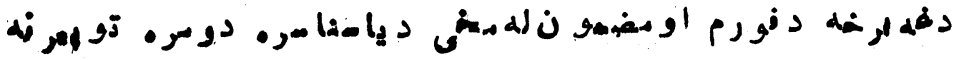

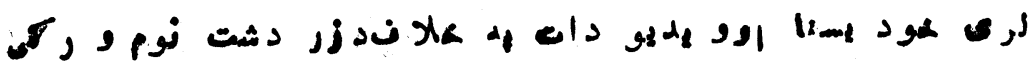

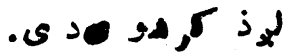

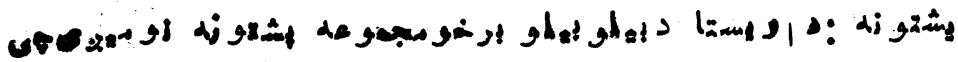

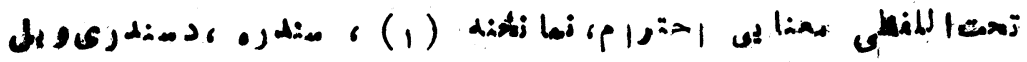

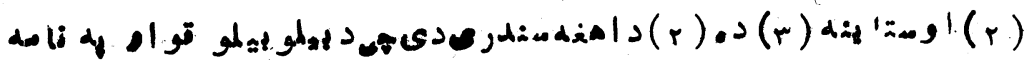

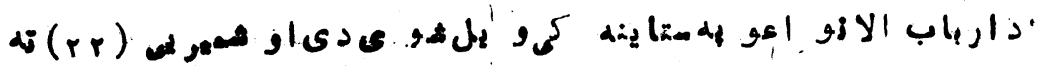

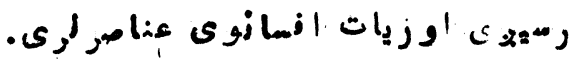

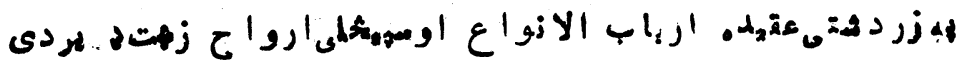

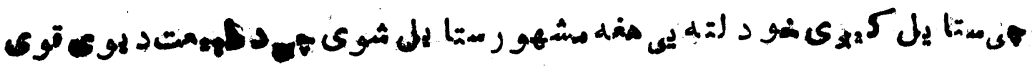

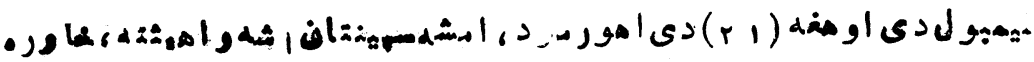

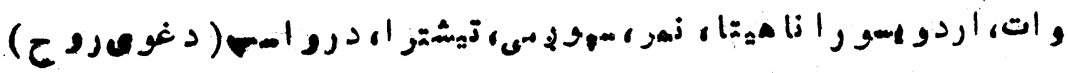

ا - ار

tor $(i \wedge)($ athe 


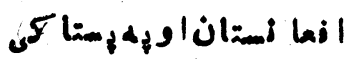

$-1 \pi \cdot-$

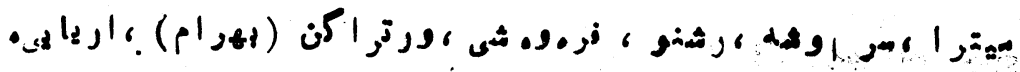

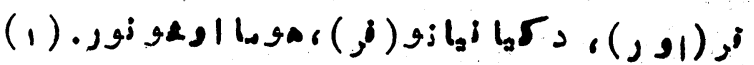

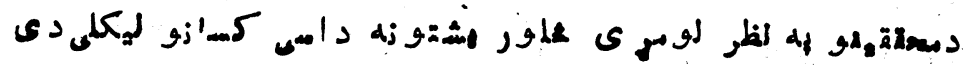

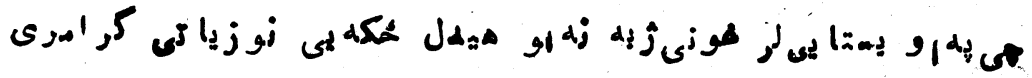

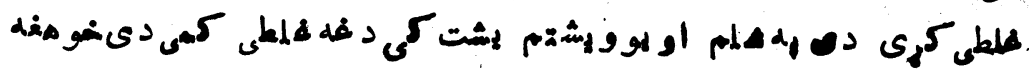

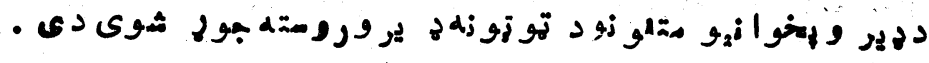

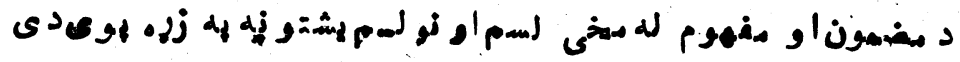

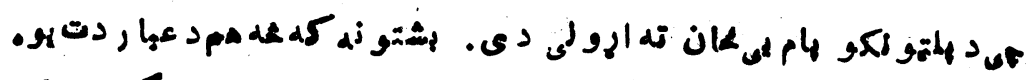

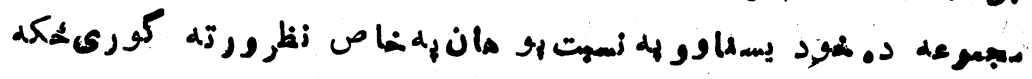

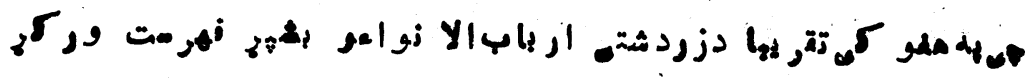

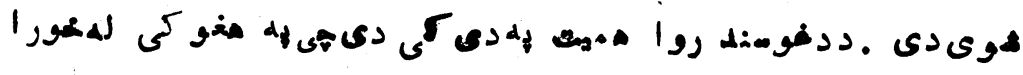

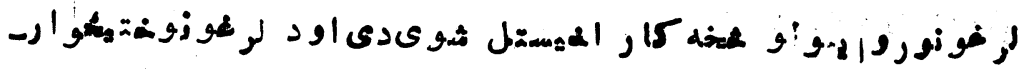

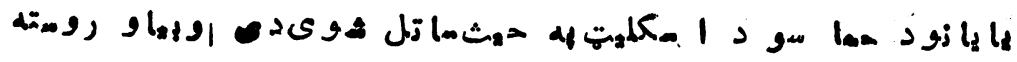

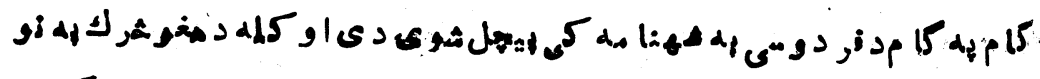

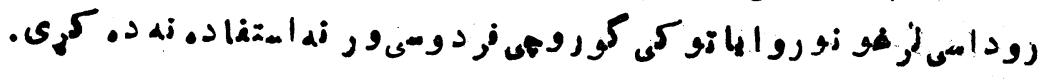

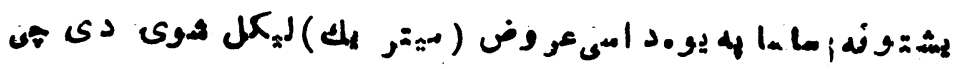

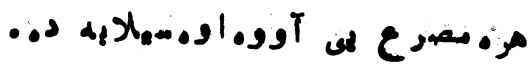

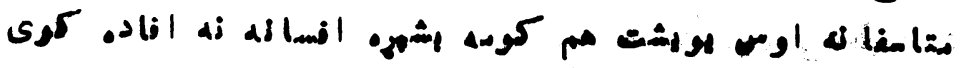

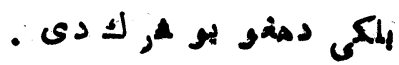

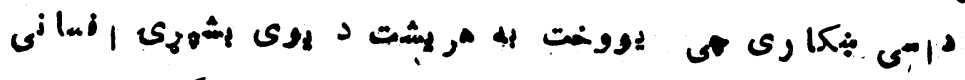

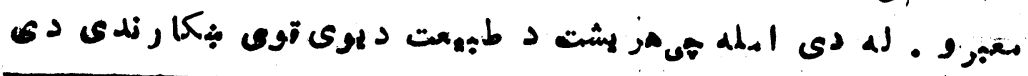

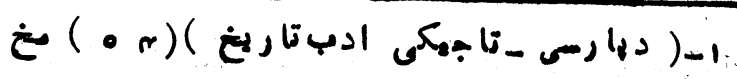




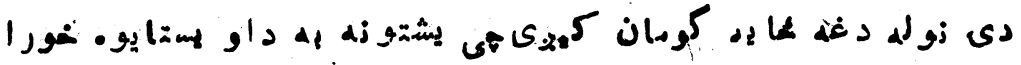

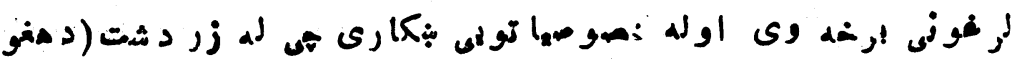

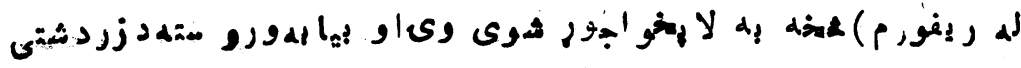

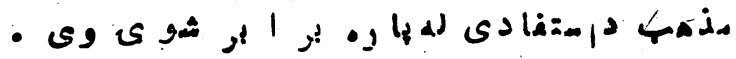

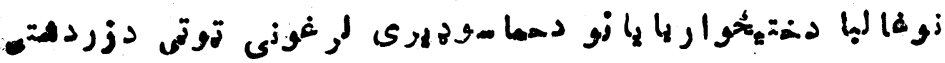

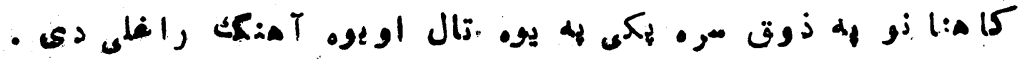

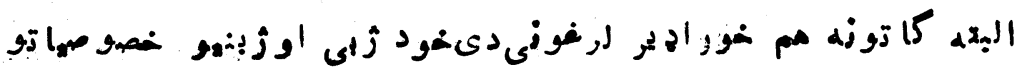

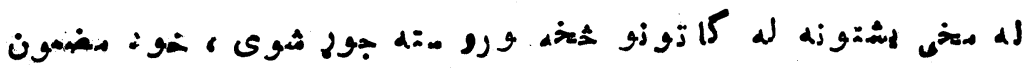

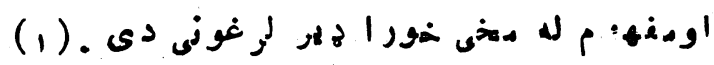

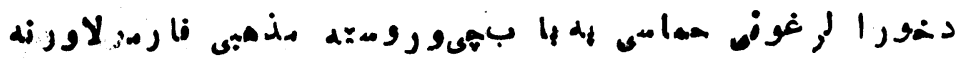

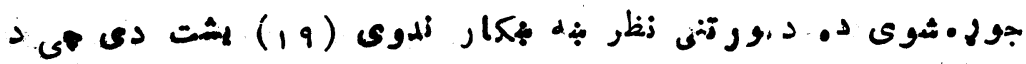

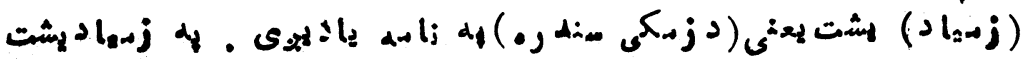

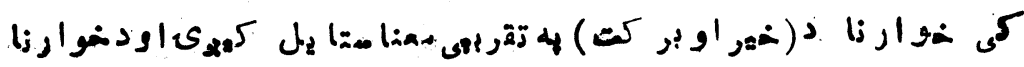

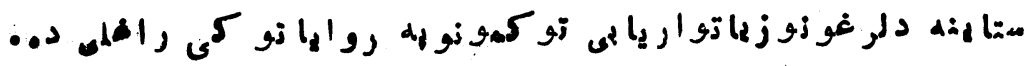

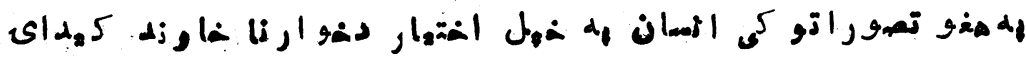

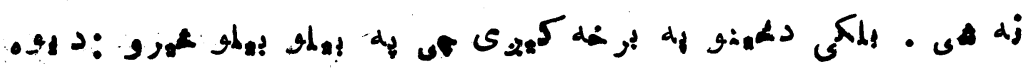

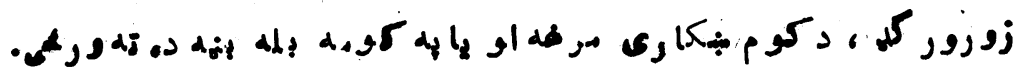

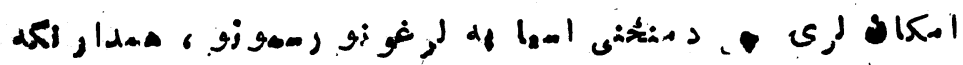

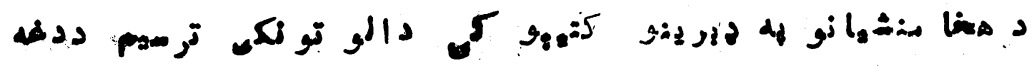

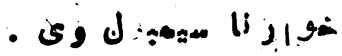

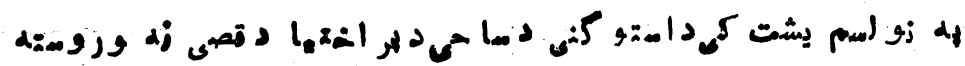




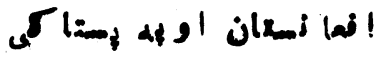

- ImY-

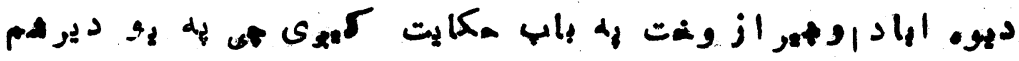

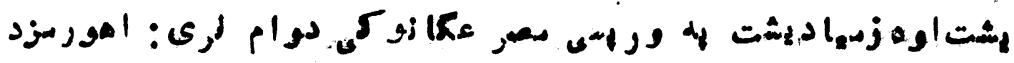

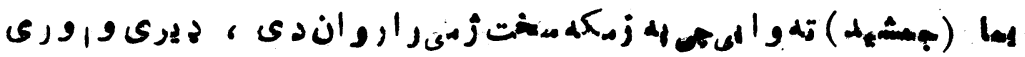

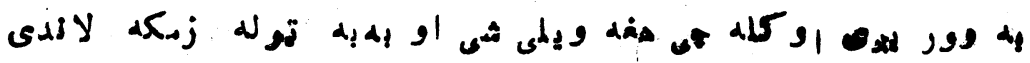

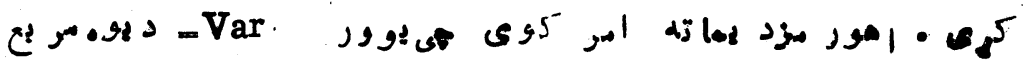

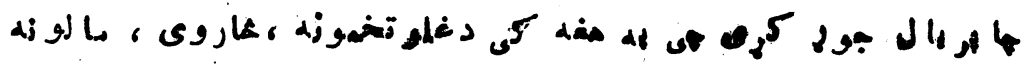

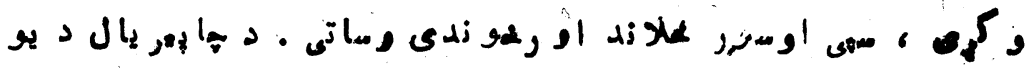

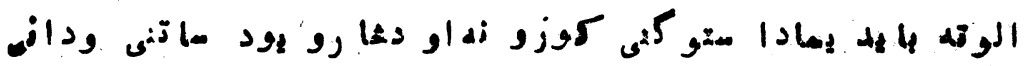

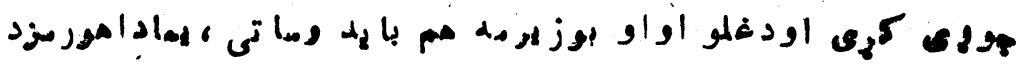

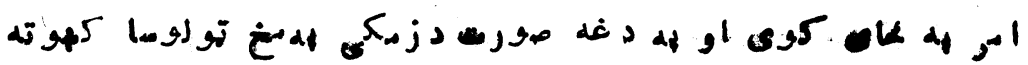

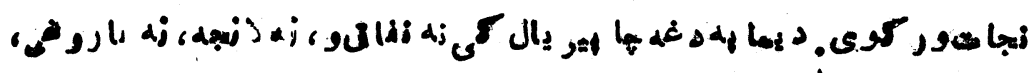
i

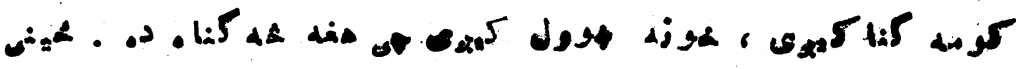

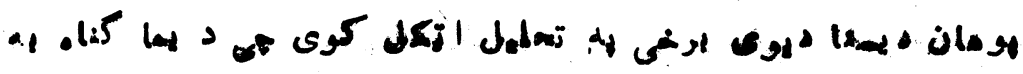

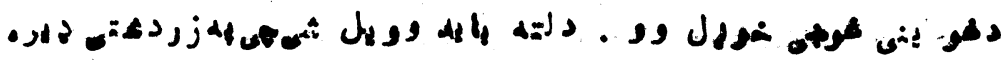

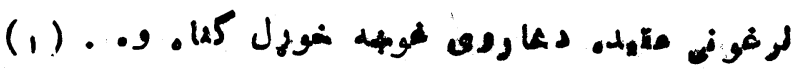

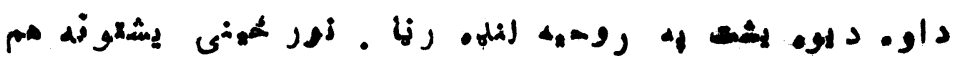

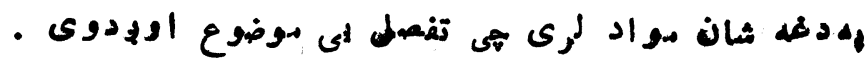

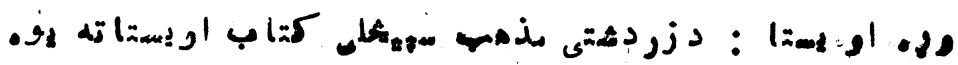

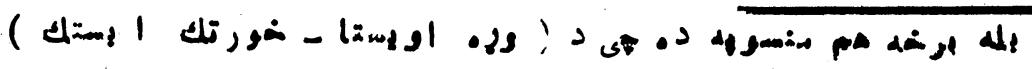

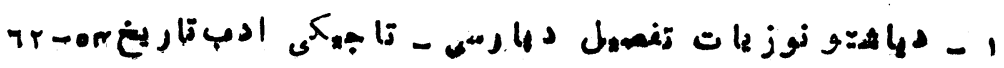

- منفوند 
$-1 m r-$

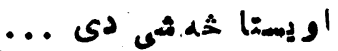

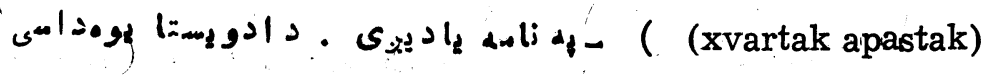

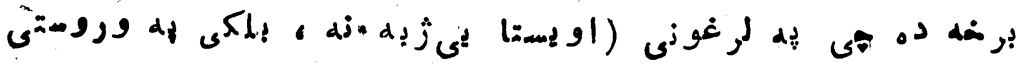

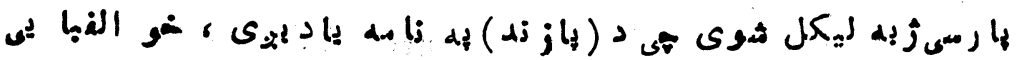

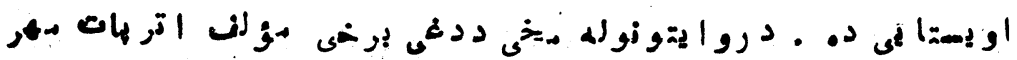

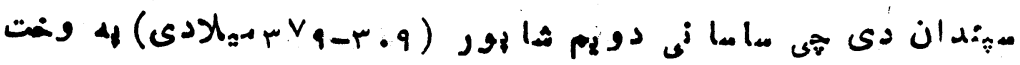

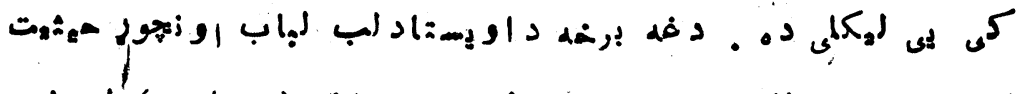

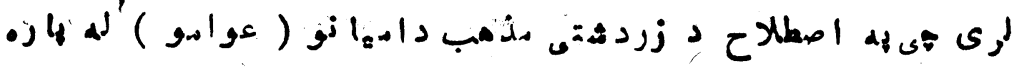

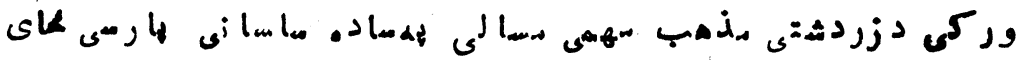

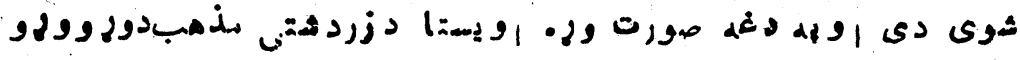

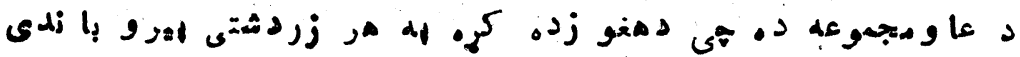
(1) • (1) الازه

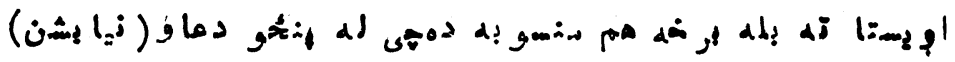

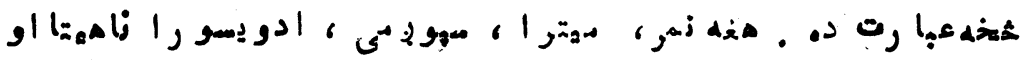

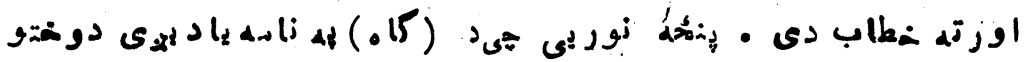

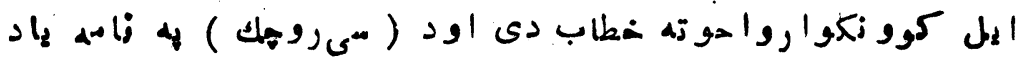

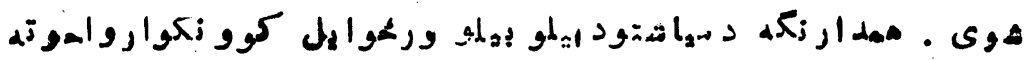

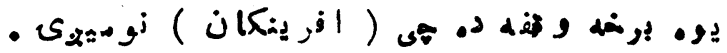

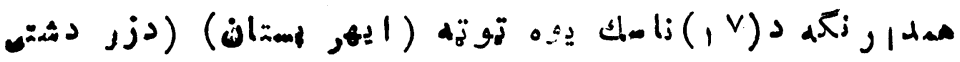

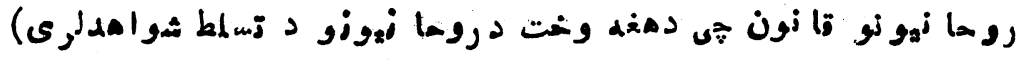

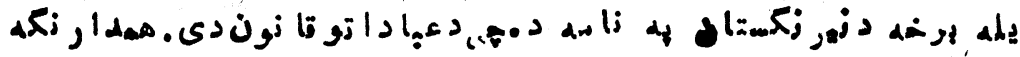

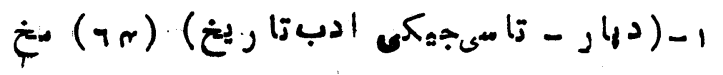




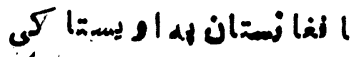

-1 rr

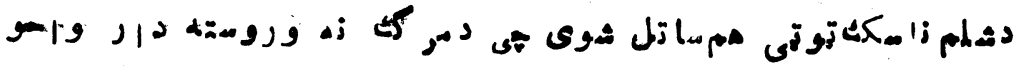

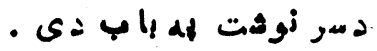

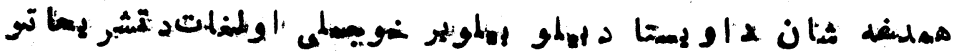

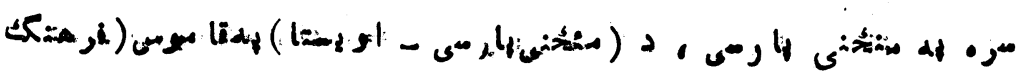

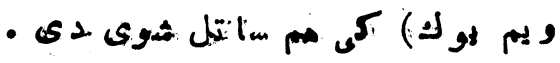

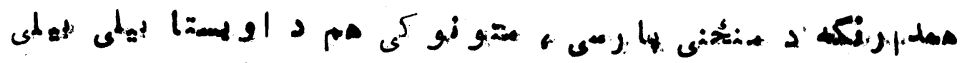

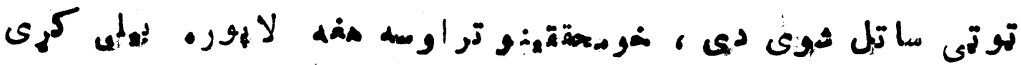

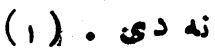

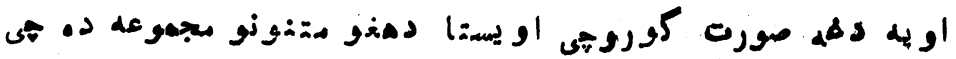

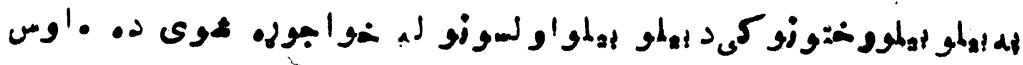

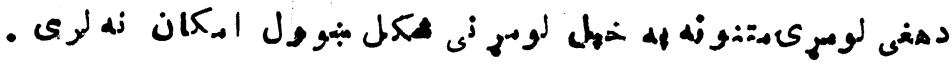

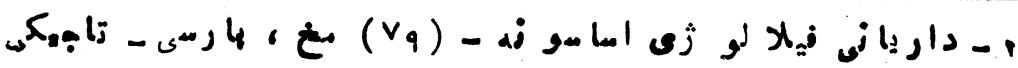

ادب rمان

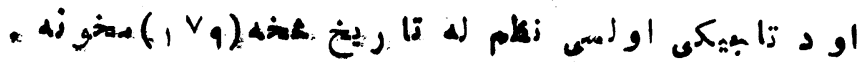




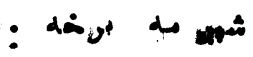

داوإستا دغيرلو تار يخجيه

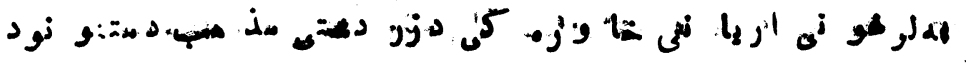

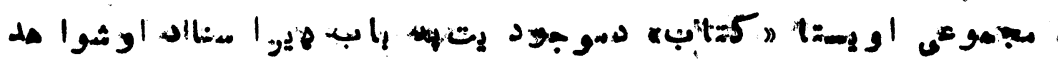

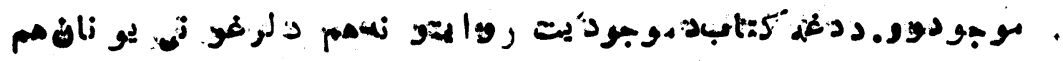

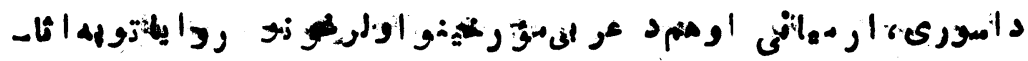

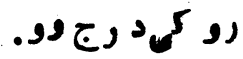

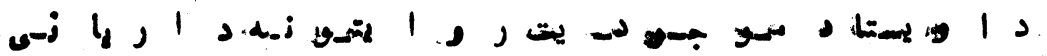

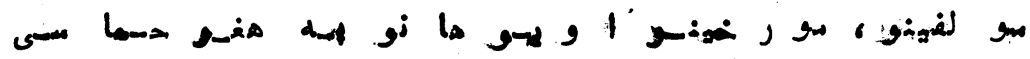

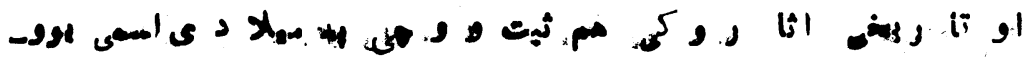

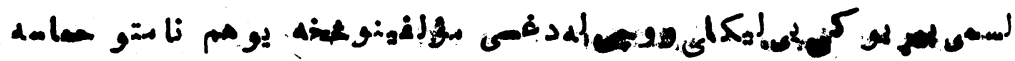

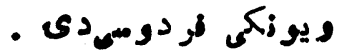

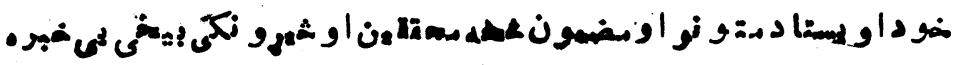

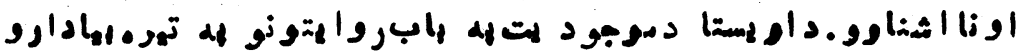

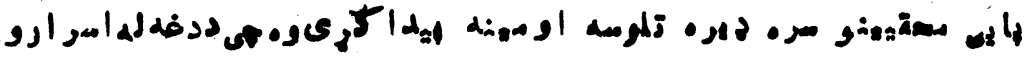




\section{)}

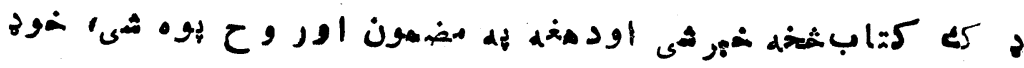

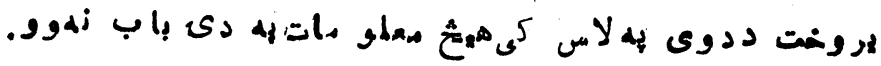

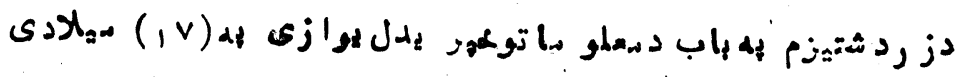

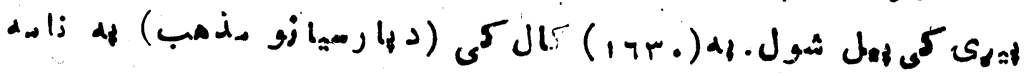

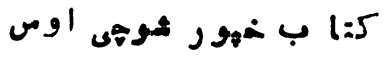
(Henrylord) अ ل لإند

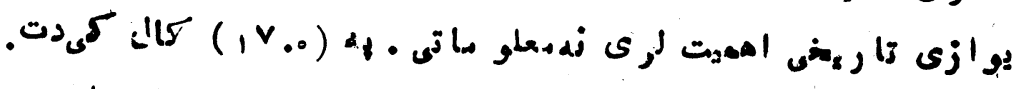

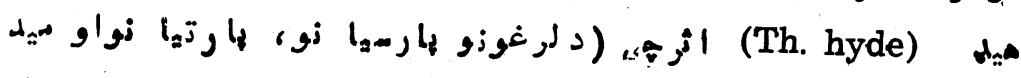

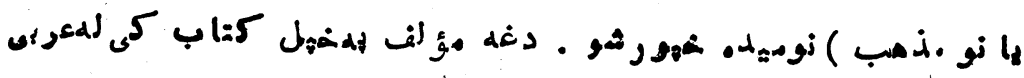

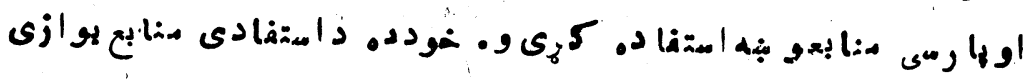

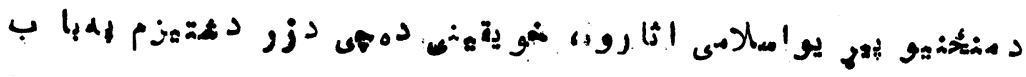

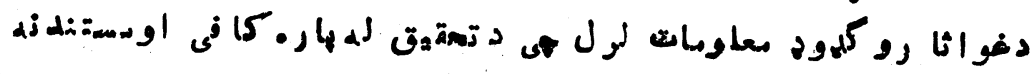

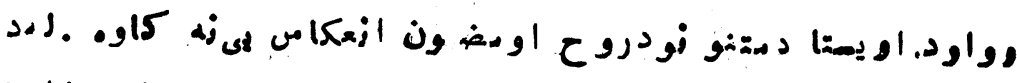

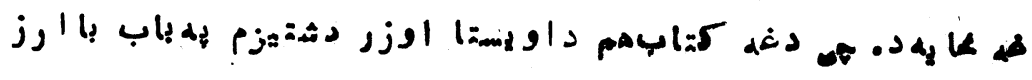

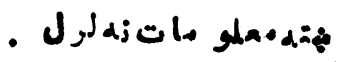

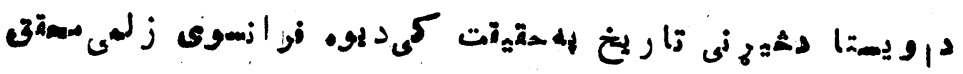

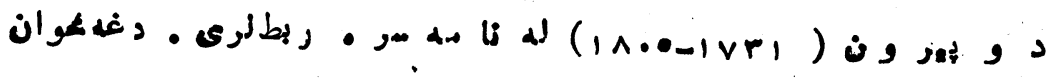

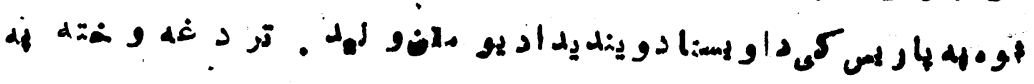

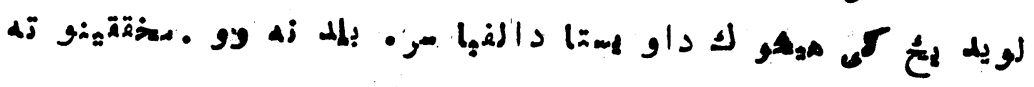

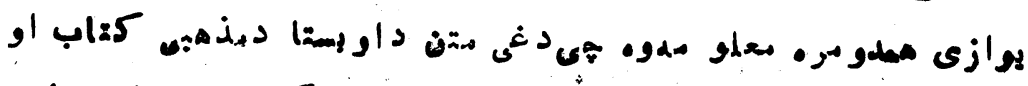

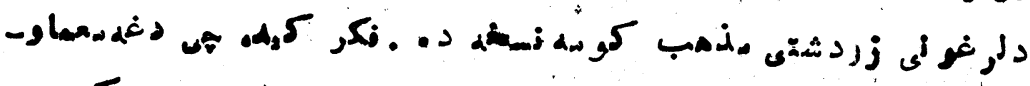

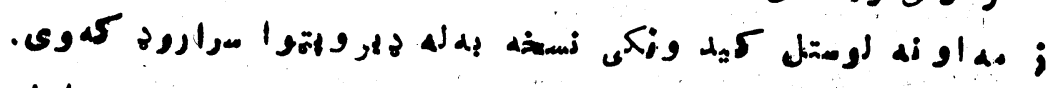

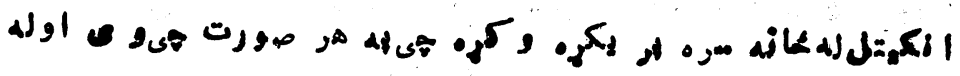




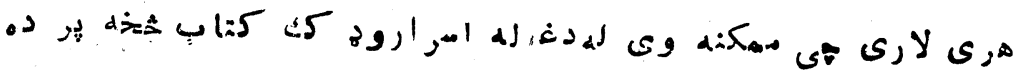

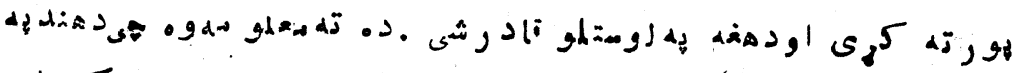
.

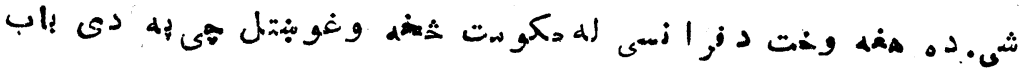

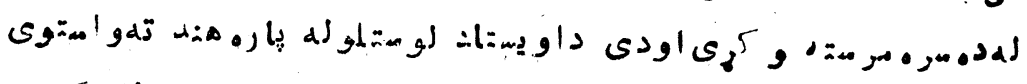

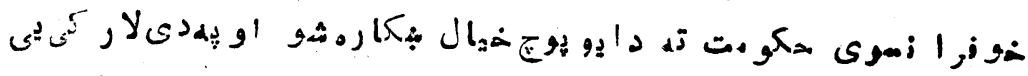

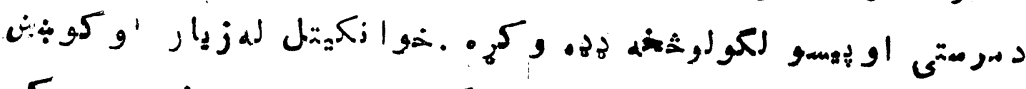

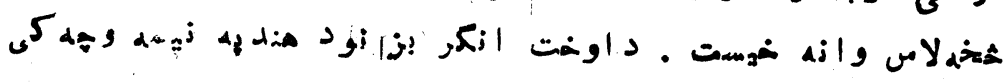

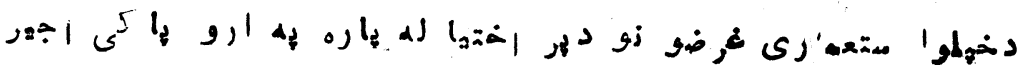

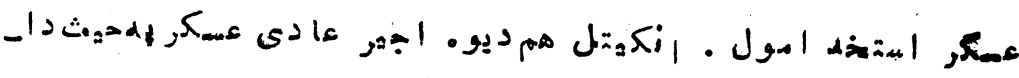

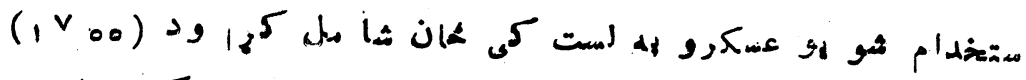

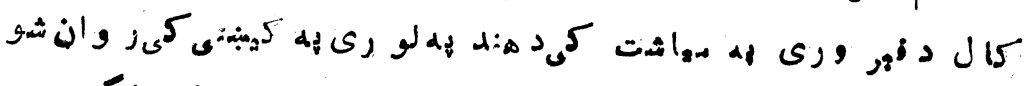

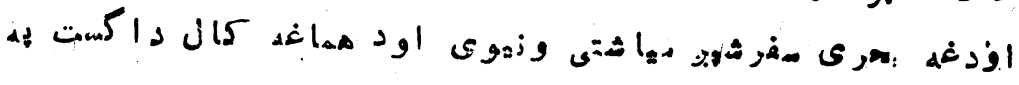

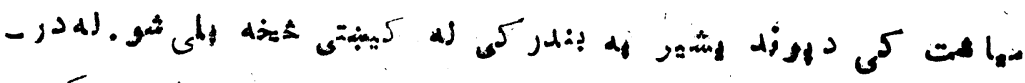

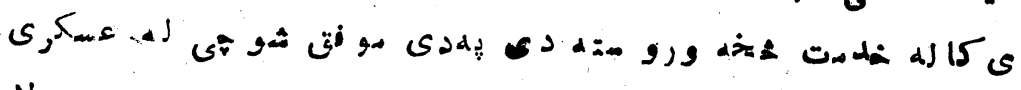

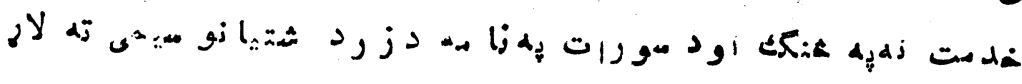

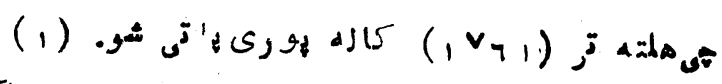

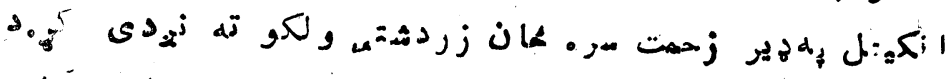

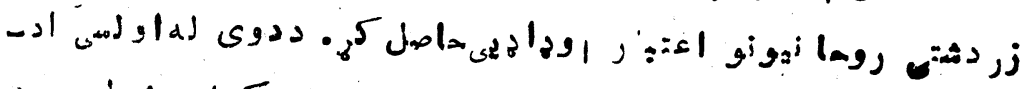

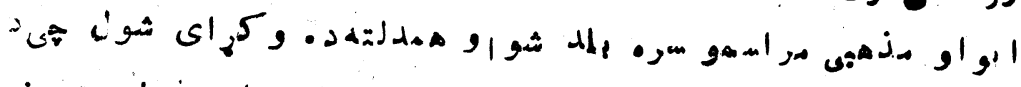

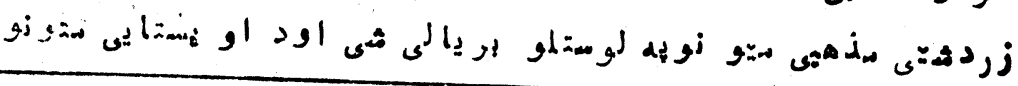

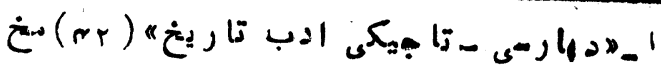




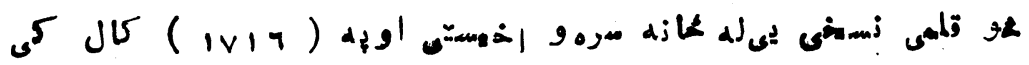

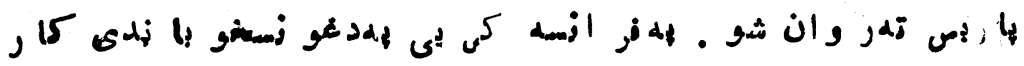

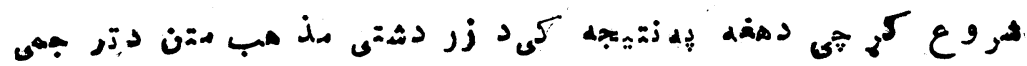

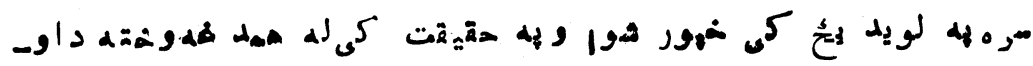

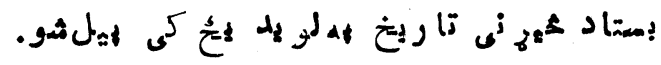

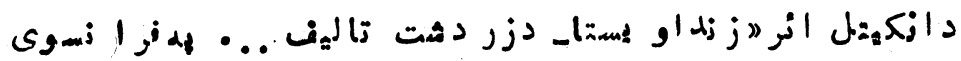

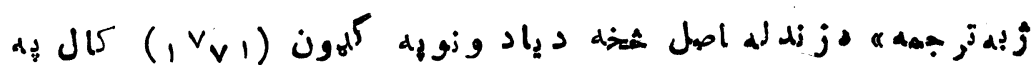

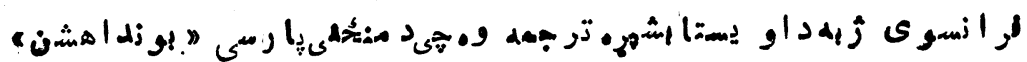

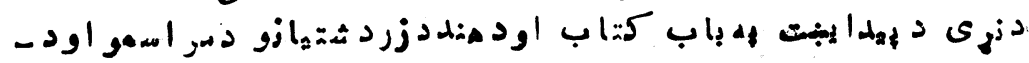

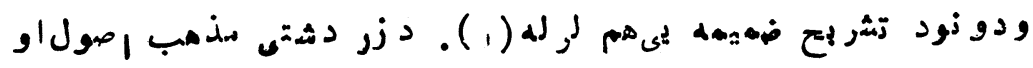

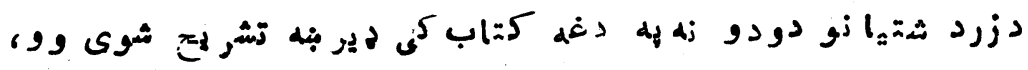

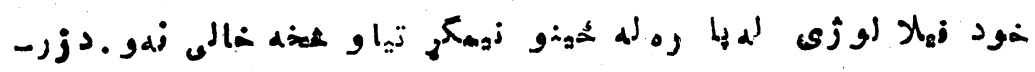

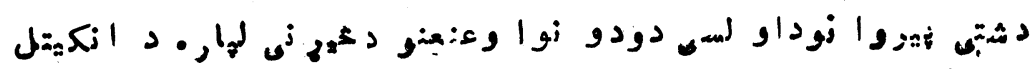

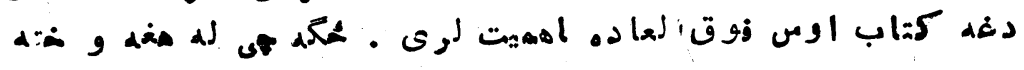

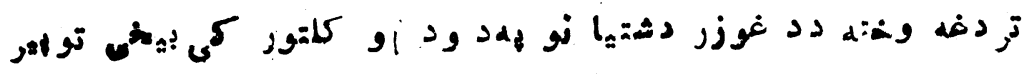

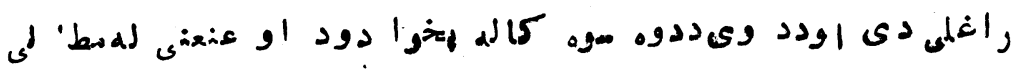

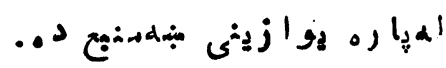

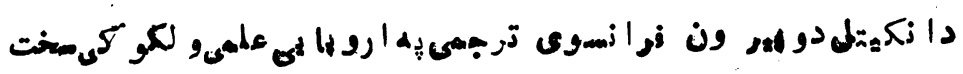

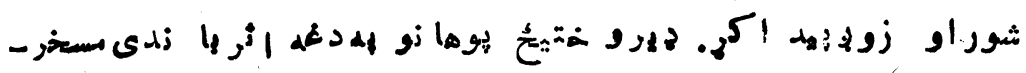

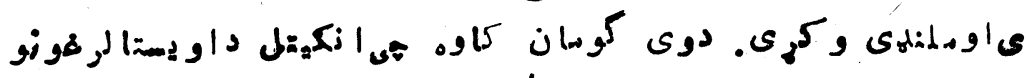

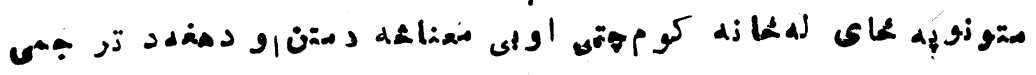

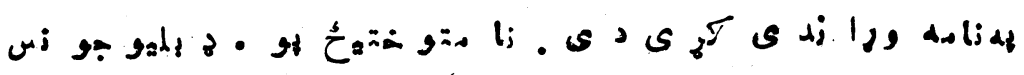

هخو 
$-109-$

S S

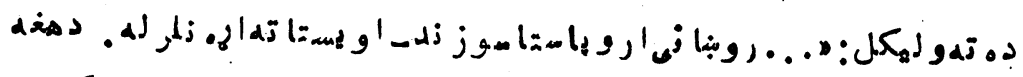

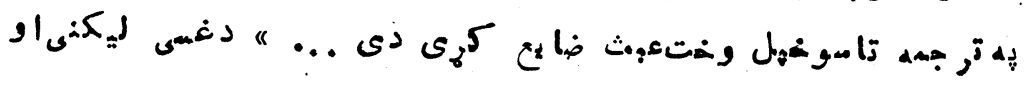

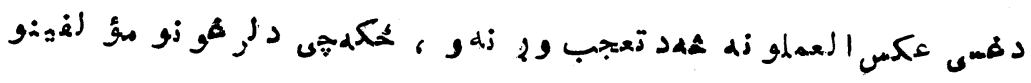

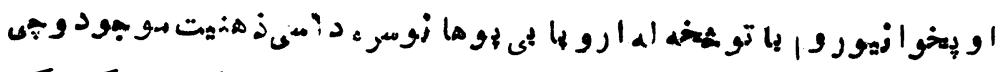

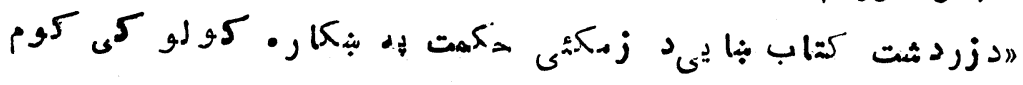

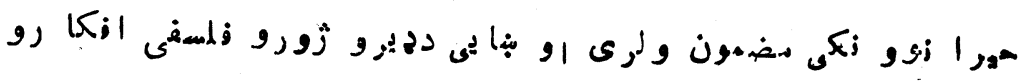

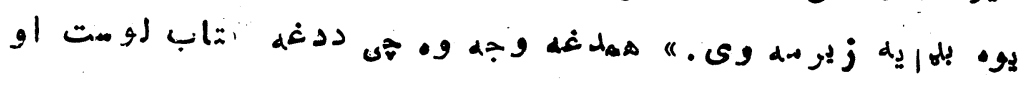

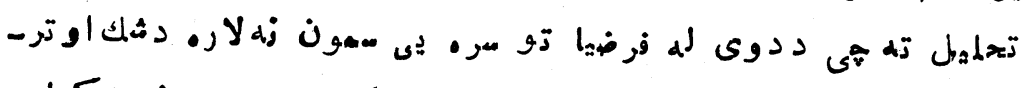

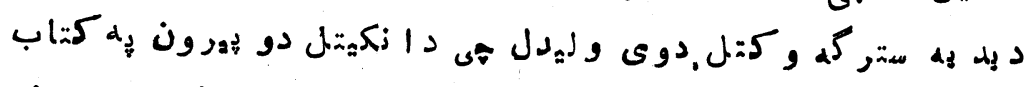

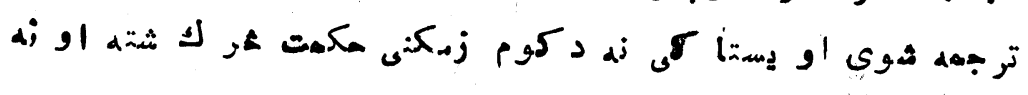

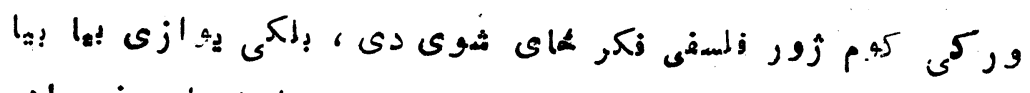

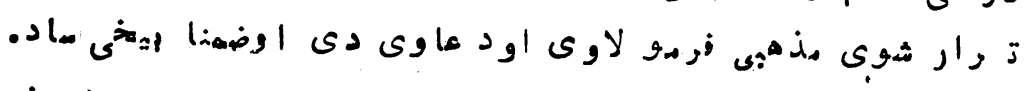

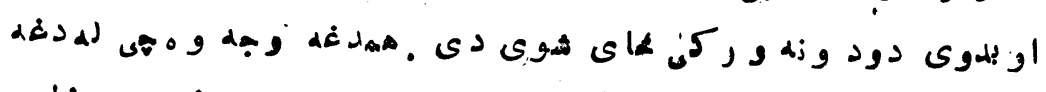

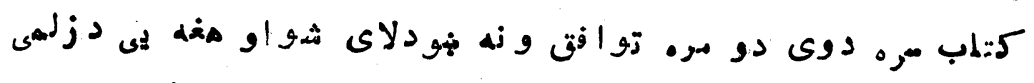

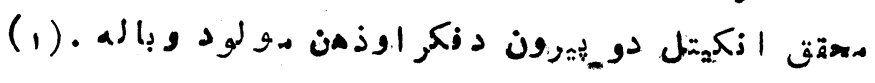

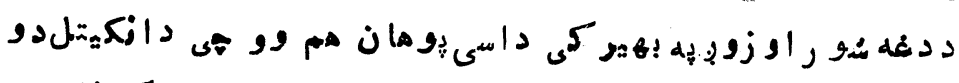

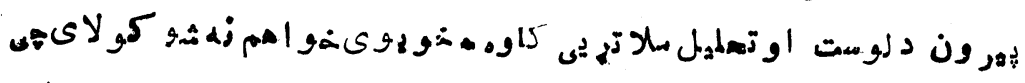

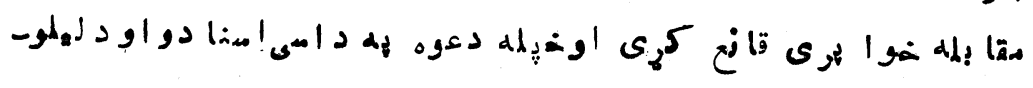

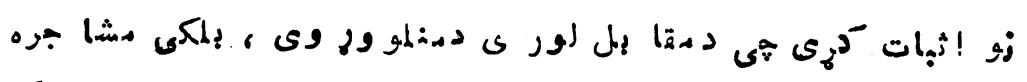

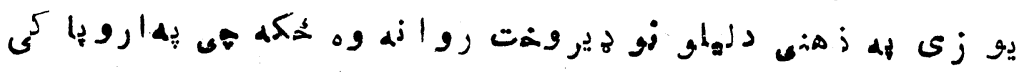

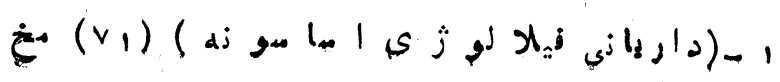




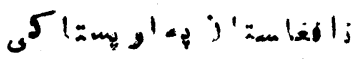

$-10$.

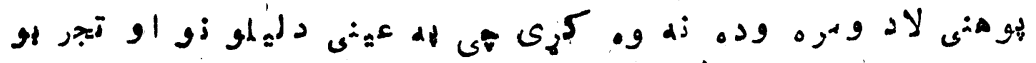

$$
\text { - دنه لازنجه يوى خوانه }
$$

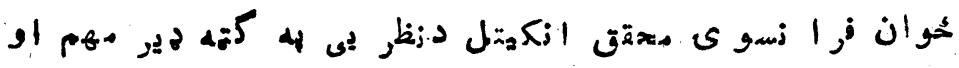

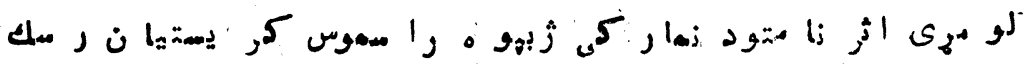

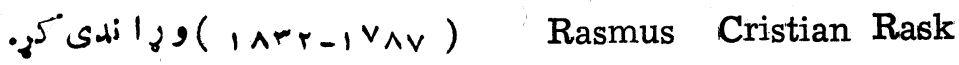

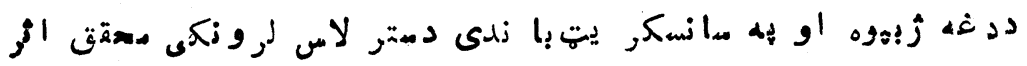

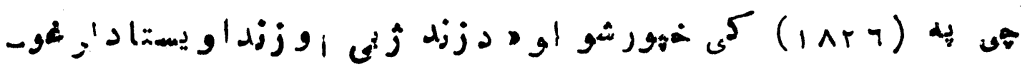

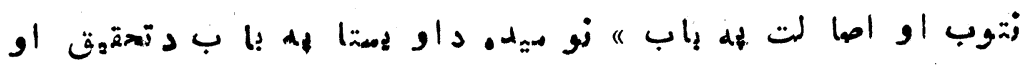

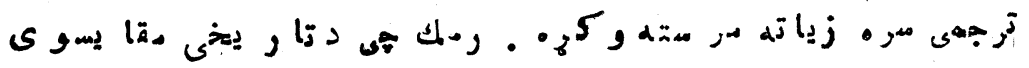

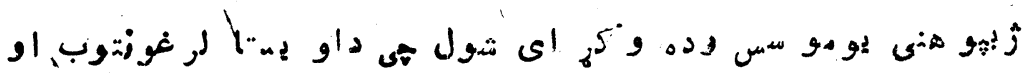

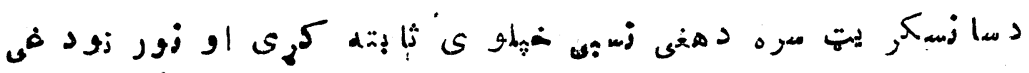

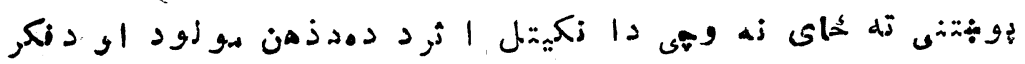

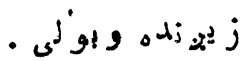

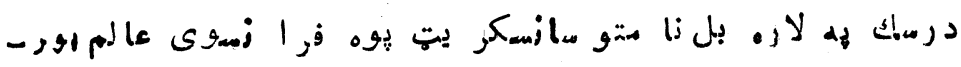
زو ف

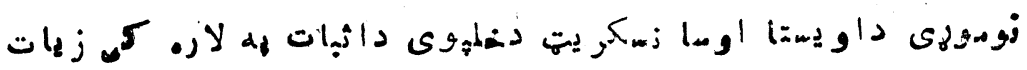

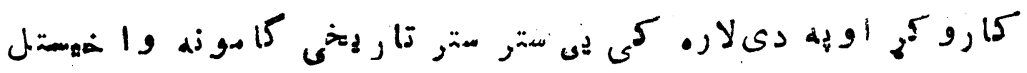

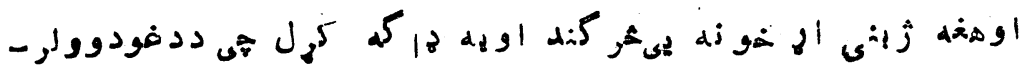

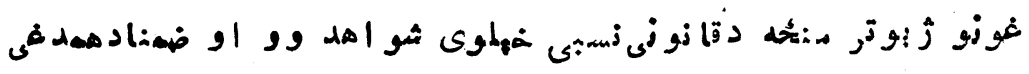

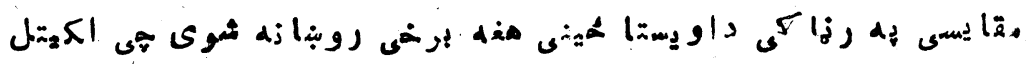

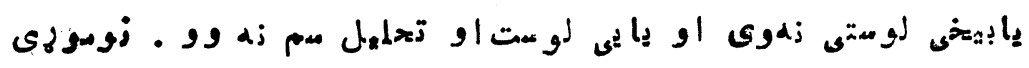

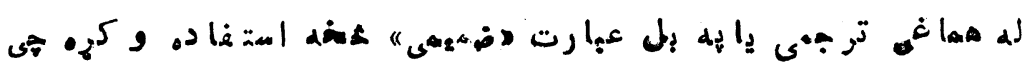


$-1 \cdot 1-$

...

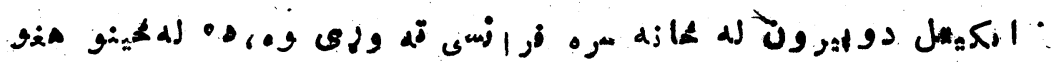

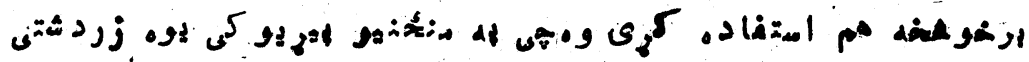

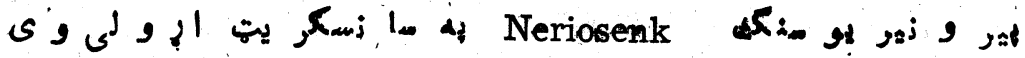

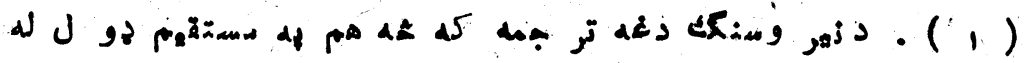

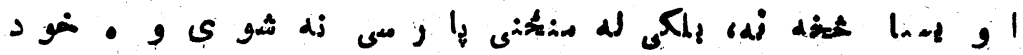

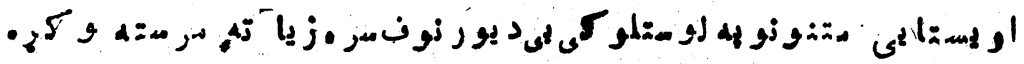

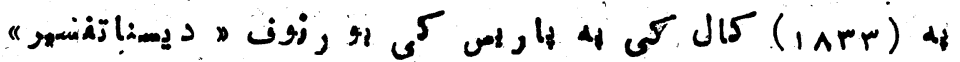

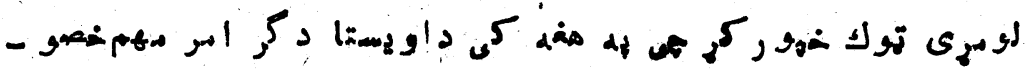

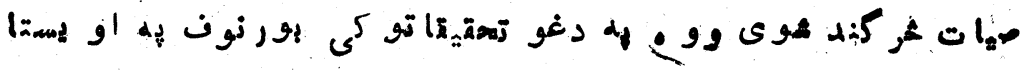

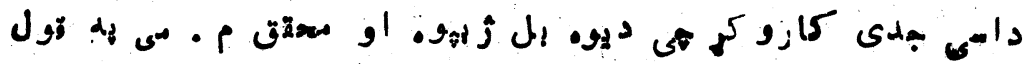

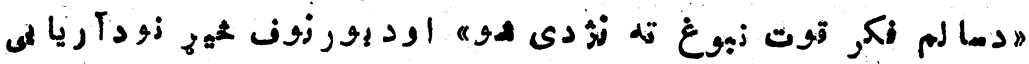

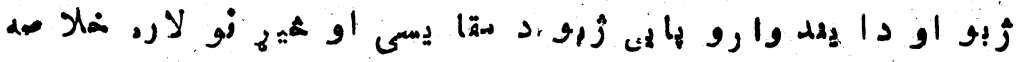

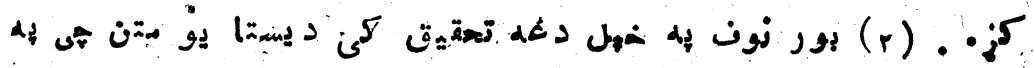

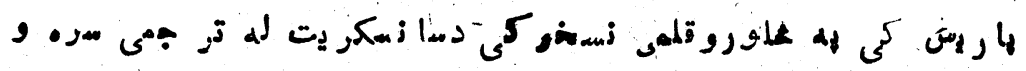

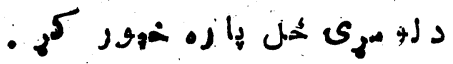

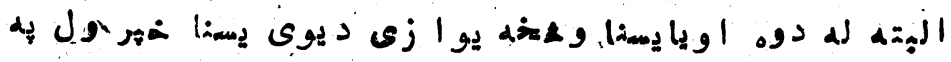

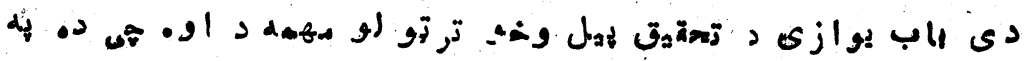

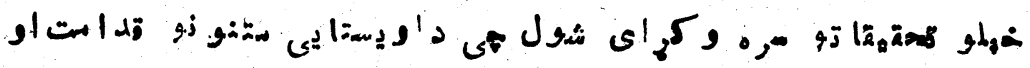

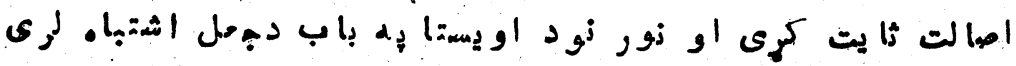

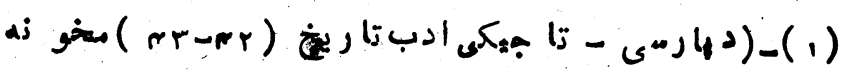

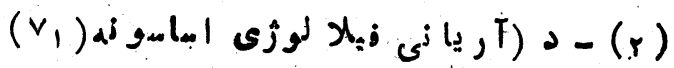




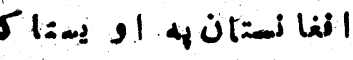

$-1 \cdot r-$

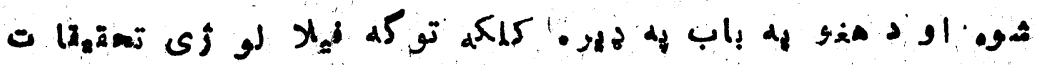

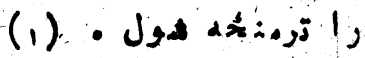

dا ه

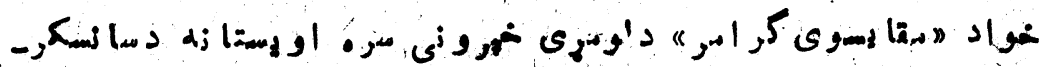

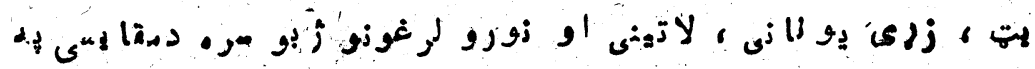

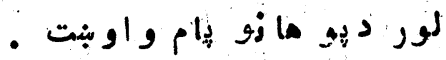

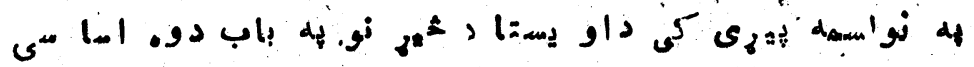

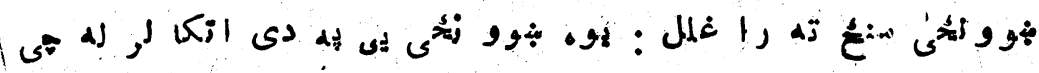

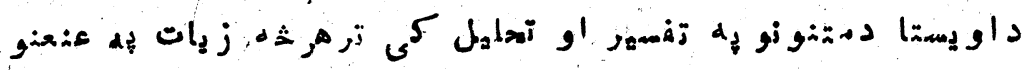

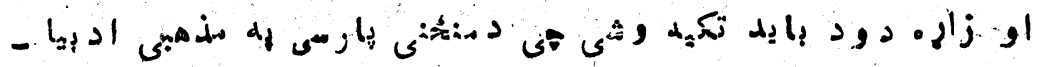

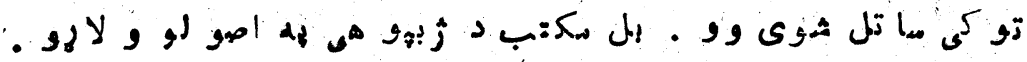

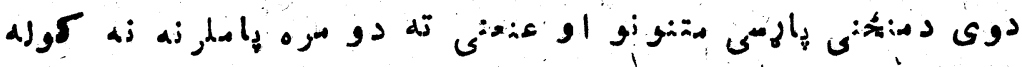

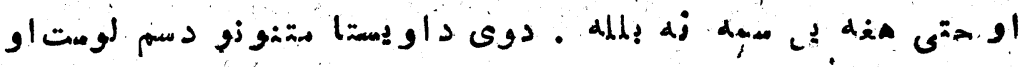

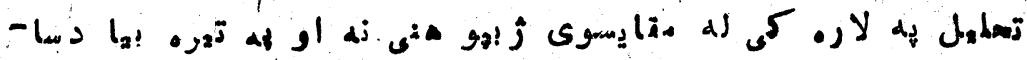

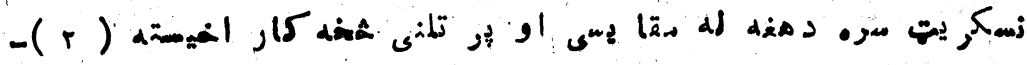

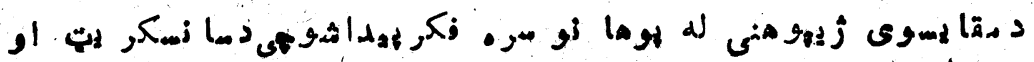

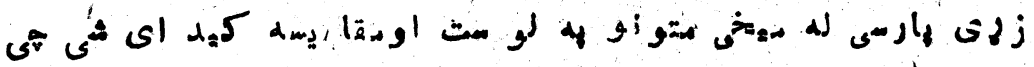

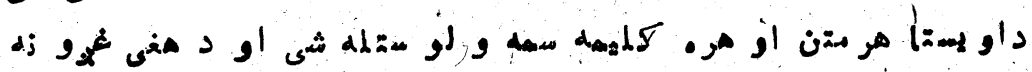

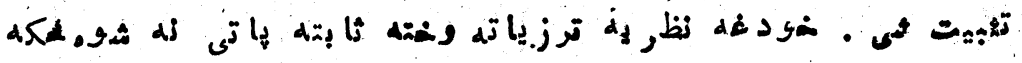

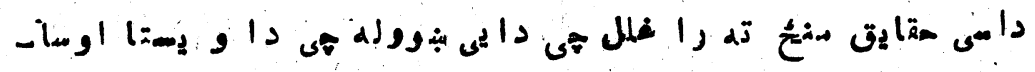

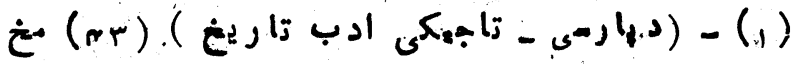

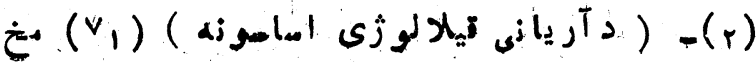


$-10 \%-$

. . 5 tod

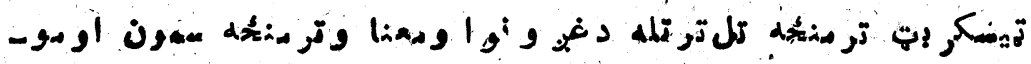

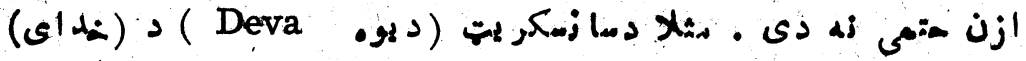

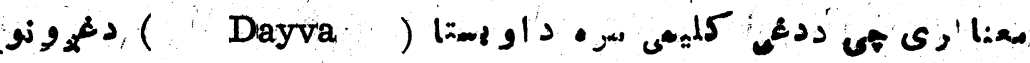

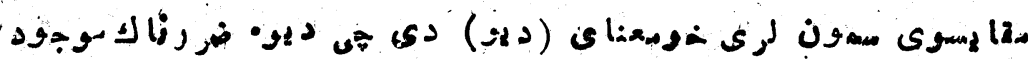

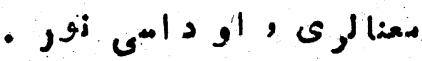

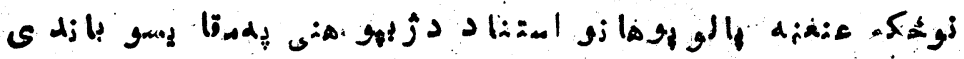

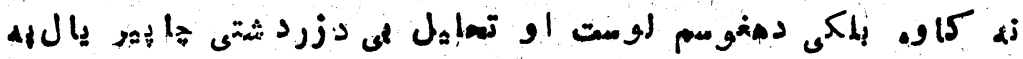

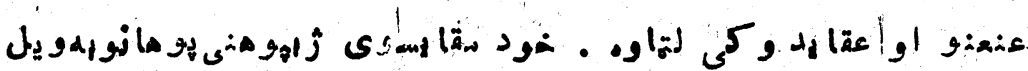

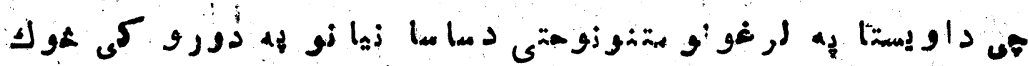

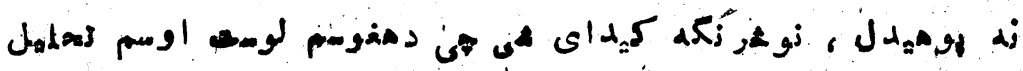

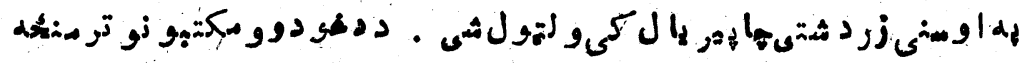

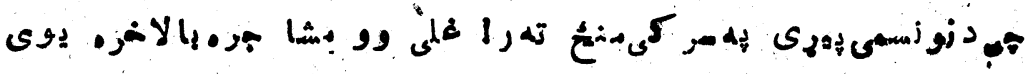

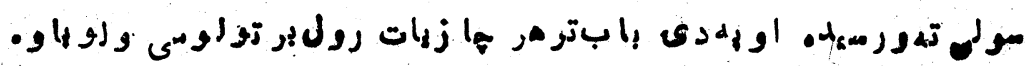

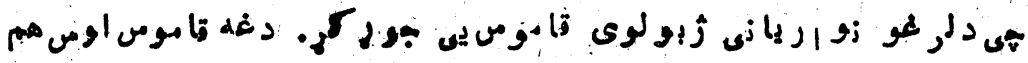

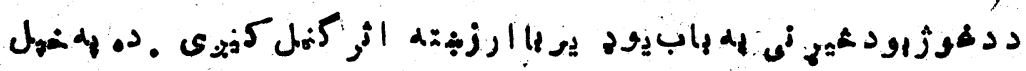

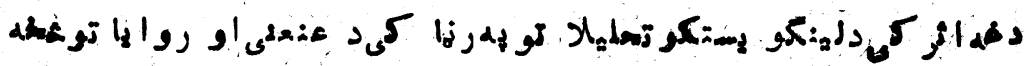

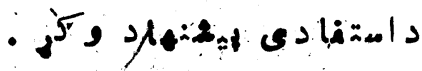

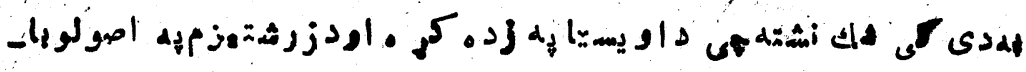

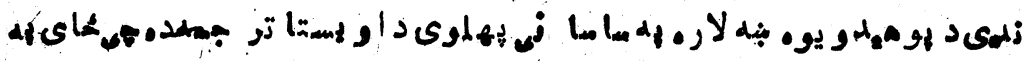

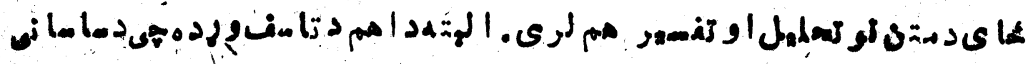

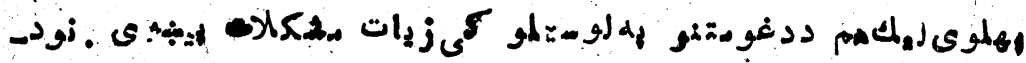




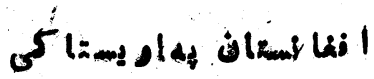

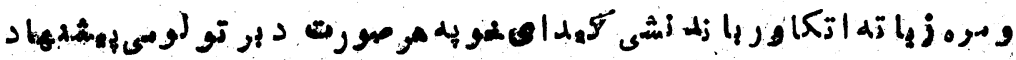

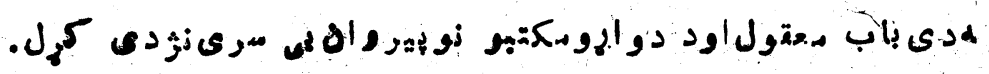

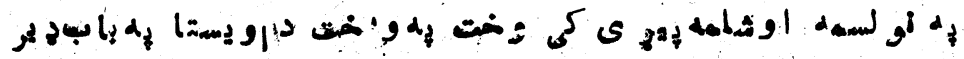

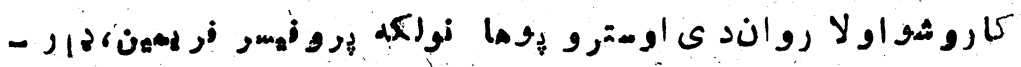

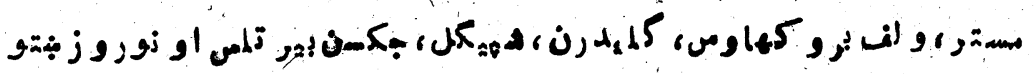

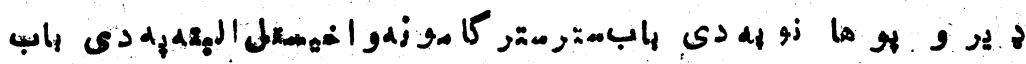

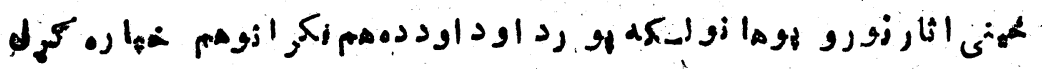

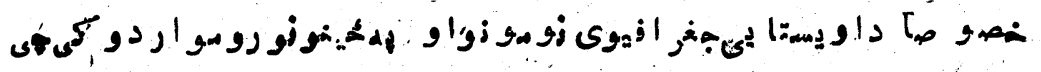

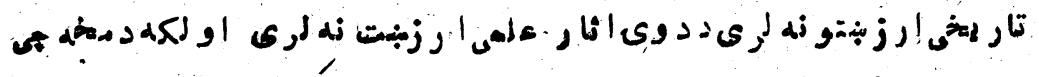

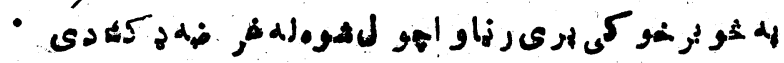




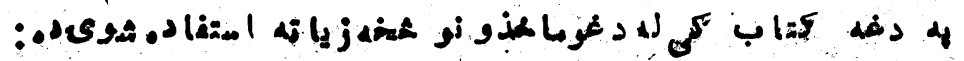

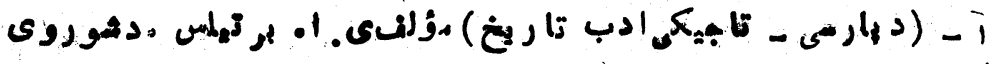

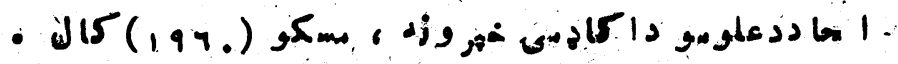

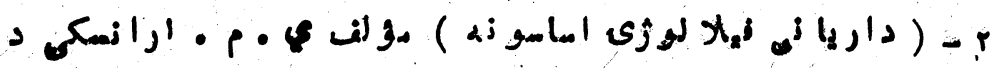

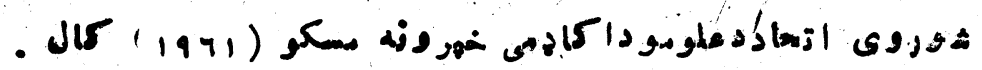

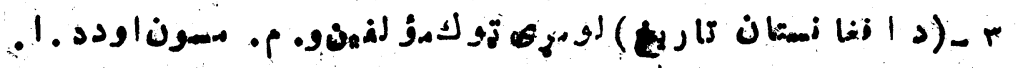

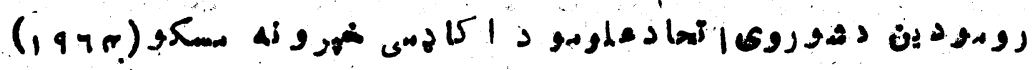

- J J

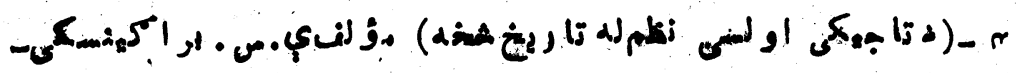

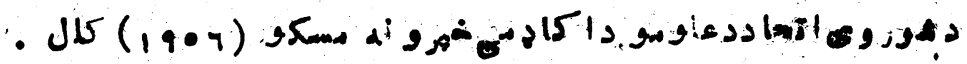

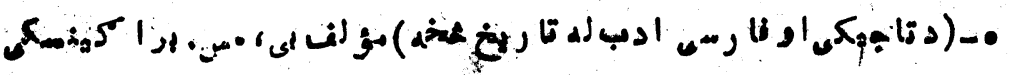

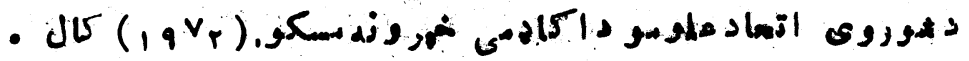

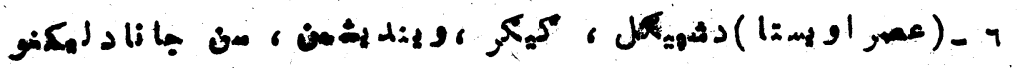

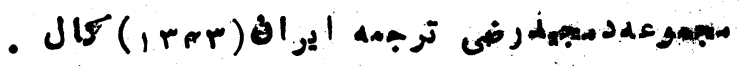

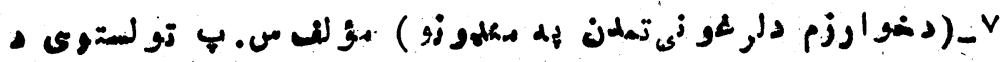

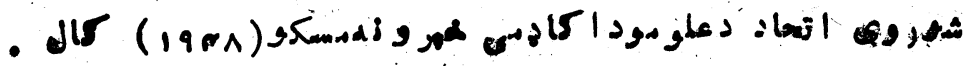

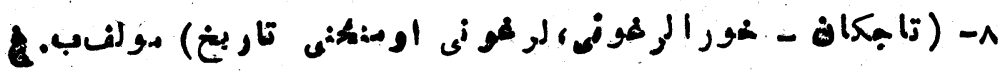

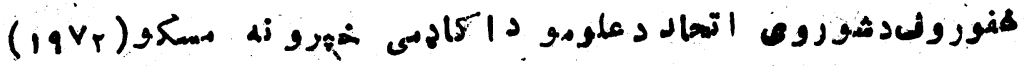

- d 15 


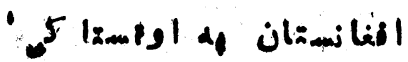

$-1.90$

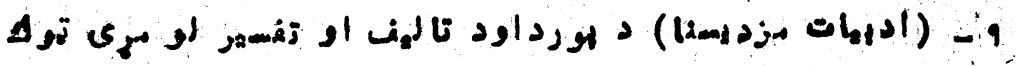

- usat Jutren

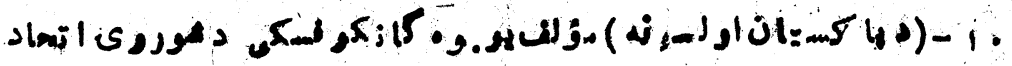

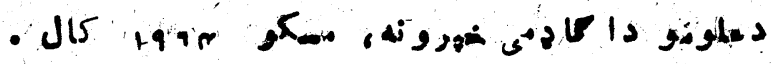

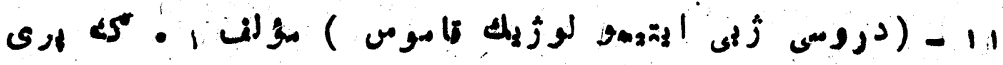

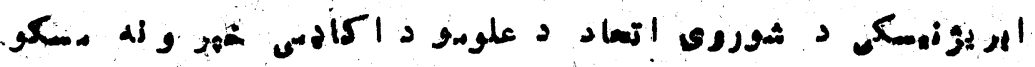

. J 15 1909

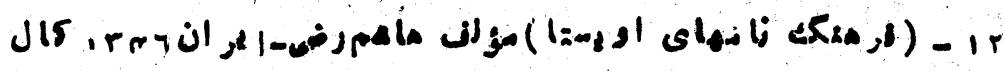

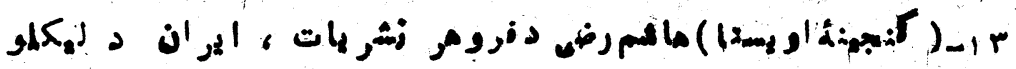

- م gan di ja j15

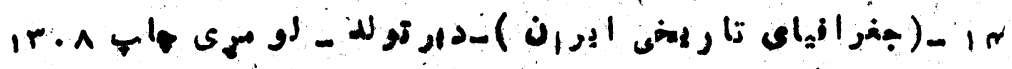

ن

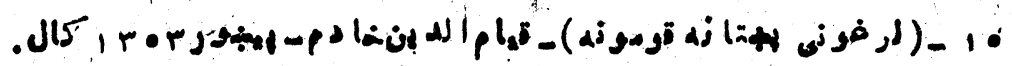


سمونليك.

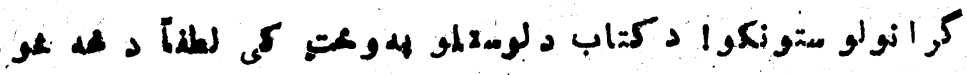
': زكى

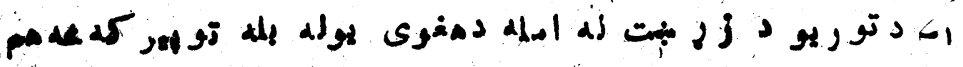

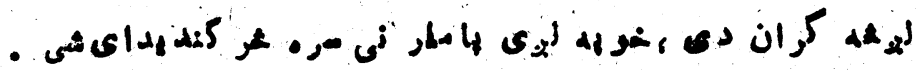
أ

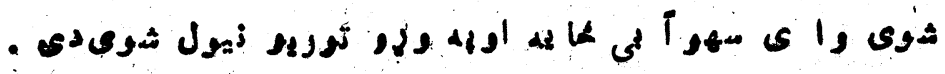

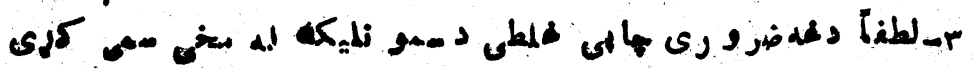

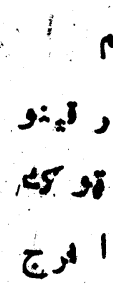

او polis 4,5

$\dot{c}$ مثشر أهن

17

。

d

ir

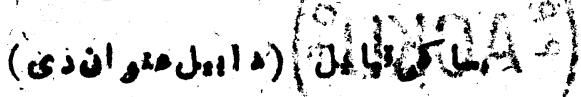

$v$

$v \quad r$

$d 5$ 


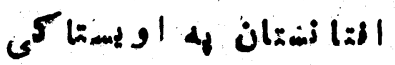

$-1 \bullet A-$

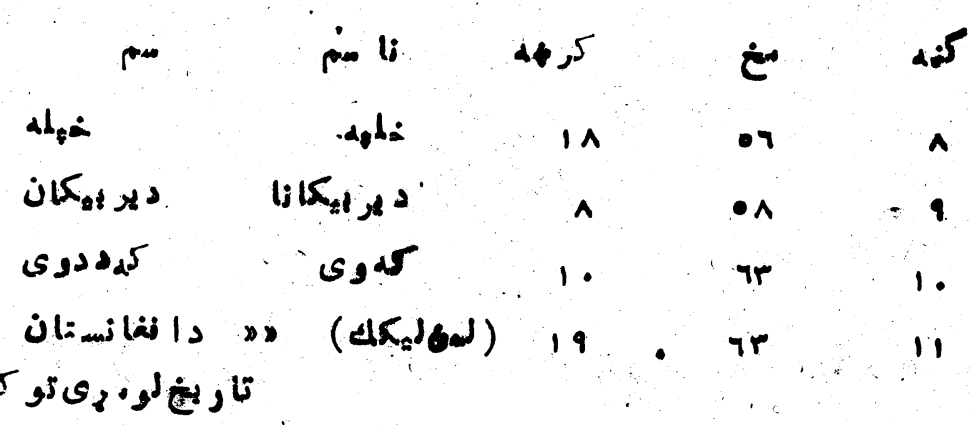

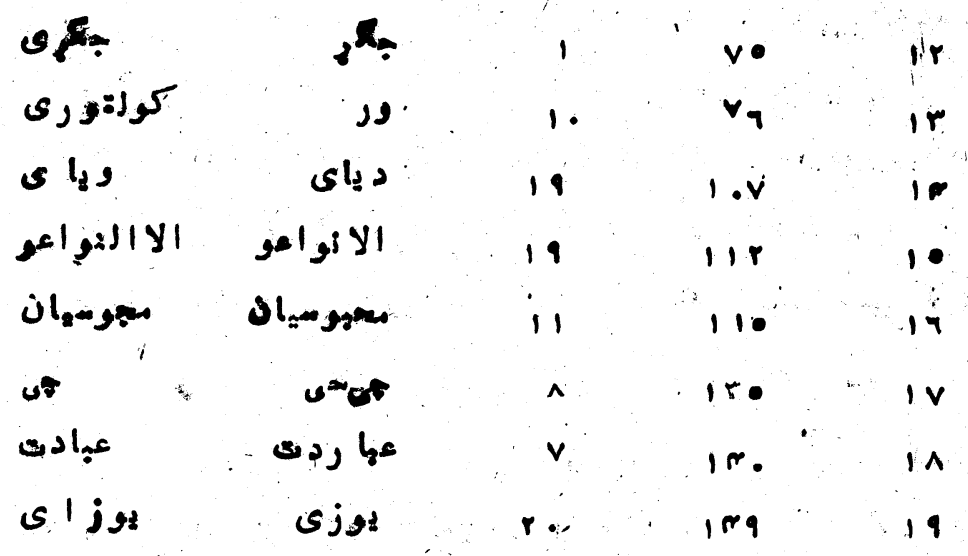

ACKU

4067 